UNIVERSIDADE DE SÃO PAULO

FFCLRP-DEPARTAMENTO DE PSICOLOGIA E EDUCAÇÃO

PROGRAMA DE PÓS-GRADUAÇÃO EM PSICOLOGIA

\title{
"Da informação à educação em saúde: \\ a CIPA e sua atividade educativa em uma empresa de Ribeirão Preto, SP.”
}

Irevan Vitória Marcellino

Tese apresentada à Faculdade de Filosofia, Ciências e Letras de Ribeirão Preto da USP, como parte das exigências para a obtenção do título de Doutor em Ciências, Área: Psicologia.

RIBEIRÃO PRETO - SP 
UNIVERSIDADE DE SÃO PAULO

FFCLRP-DEPARTAMENTO DE PSICOLOGIA E EDUCAÇÃO

PROGRAMA DE PÓS-GRADUAÇÃO EM PSICOLOGIA

\title{
“Da informação à educação em saúde: \\ a CIPA e sua atividade educativa em uma empresa de Ribeirão Preto, SP."
}

\author{
Irevan Vitória Marcellino \\ Orientadora: Profa. Dra. Lisete Diniz Ribas Casagrande
}

Tese apresentada à Faculdade de Filosofia, Ciências e Letras de Ribeirão Preto da USP, como parte das exigências para a obtenção do título de Doutor em Ciências, Área: Psicologia.

RIBEIRÃO PRETO - SP

2004 
AUTORIZO A REPROdUÇÃo E DIVULGaÇão TOTAL OU PARCIAL DESTE TRABALHO, POR QUALQUER MEIO CONVENCIONAL OU ELETRÔNICO, PARA FINS DE ESTUdO E PESQUISA, DESDE QUE CITADA A FONTE.

\section{FICHA CATALOGRÁFICA}

Marcellino, Irevan Vitória

Da informação à educação em saúde: a CIPA e sua atividade educativa em uma empresa de Ribeirão Preto, SP. Ribeirão Preto, 2004.

268 p. : il.; $30 \mathrm{~cm}$

Tese, apresentada à Faculdade de Filosofia, Ciências e Letras de Ribeirão Preto / USP - Dep. de Psicologia e Educação.

Orientadora: Casagrande, Lisete Diniz Ribas.

1. Educação em saúde. 2. Prevenção de acidentes. 3. Promoção à saúde. 4. Saúde do trabalhador.

\section{Capa:}

Materiais utilizados na prevenção de acidentes do trabalho.

Fotografia: Marcelo Cleomar T. Simões

Ribeirão Preto - SP 


\section{DEDICATÓRIA}

Dedico este trabalho investigativo a todos os educadores e trabalhadores da saúde que lidam com a educação, como meio de conscientização e de promoção à saúde; e desse modo, acenam para a existência de um poder de transformação nos ambientes de trabalho, contribuindo para um país melhor e mais justo. 


\section{AGRADECIMENTOS}

“Amigo é coisa pra se guardar do lado esquerdo do peito dentro do coração...”

(Milton Nascimento)

Minha trajetória acadêmica iniciou-se em 1994, quando cheguei a Ribeirão Preto, para fazer a residência médica em Medicina Social. Dois anos mais tarde, resolvi fazer mestrado em Medicina Preventiva e Social, com ênfase em Saúde do Trabalhador. Nesse percurso, conheci muita gente que compartilhou comigo meus sonhos e expectativas de uma saúde melhor. Destaco entre elas, os meus professores da Universidade Federal de Santa Catarina (UFSC) da Faculdade de Medicina Marcão, Lúcio, César e Liana; da Universidade de São Paulo (USP) campus Ribeirão Preto da Faculdade de Medicina do Departamento de Medicina Social (DMS), Prof. Dra. Aldaísa Cassanho Forster, Prof. Dr. Breno G. Simões (in memoriam) e Prof. Dr. Antonio Ruffino Netto; em especial, com admiração e carinho a Prof. Dra. Neiry Primo Alessi.

Agora, em 2004, ao finalizar mais um trabalho investigativo, meus sentimentos se renovam, porém são ambíguos: um é de imensa alegria por tê-lo concluído, o outro é de uma profunda tristeza, e agora? No entanto, prefiro ficar com o primeiro, pois, além de ser o mais forte, é o presente que a vida colocou-me nas mãos e o meu presente à vida. Diante disso, minha vontade é de agradecer a todos, principalmente aos trabalhadores "cipeiros" que, por sua contribuição, tornou possível esta tese; muitas vezes me mostraram a diferença entre conhecimento e sabedoria.

À orientadora Prof. Dra. Lisete Diniz Ribas Casagrande, pessoa, que sem cuja convivência, aprendi a gostar e a admirar, pela seriedade, competência e, pela orientação paciente e livre. Ela me mostrou na prática que a relação educador-educando é sempre uma relação de troca.

À banca de qualificação, Prof. Dra. Rosemeire Scopinho e a Prof. Dra. Maria José Bistafa que, por suas preciosas recomendações, contribuíram para a melhoria da qualidade deste trabalho.

Aos professores da Faculdade de Filosofia Ciências e Letras (FFCL) da Universidade 
de São Paulo (USP), campus Ribeirão Preto, pelos conhecimentos proporcionados.

Aos colegas de trabalho, Braga, Nílson, Cristóvão, José Francisco, Betânia, Josiane, Soninha, Luciano, assim com aos técnicos de segurança e auxiliares de enfermagem do trabalho com quem já trabalhei; em especial, ao Dr. Mário Sérgio Ricci, meu colega de trabalho, que muito contribuiu para a minha formação médica, mostrandome que servir é antes de tudo um privilégio.

Agradeço, em especial, ao meu companheiro Rui Miguel que, por seu carinho, atenção e "jeitão", deu-me amor, compreensão e a força necessária para o pensar e realizar este trabalho científico.

Também especial, a minha linda família, que apesar de pequena, mostrou-se grande na compreensão. À Irene, a amiga e mãezona de todos os momentos; Vando, o pai que também é um amigão; ao meu irmão de sangue e de alma, Kako "mano véio" e à minha cunhada Sola, que trouxe ao mundo os nossos lindinhos: Neto, Laura e Luísa que tanto nos alegram com sua inocência.

Aos amigos de "Ribeirão", Sônia, Miriam e Marcelo, Edson, Perci, Bernardo e Ísis, Ana e Paulo, Márcio, Carla, Mariah, Célia, Rosane, Celiane, Mirna, Sandra, Mateus, Bernadete e Felipe, Bia e Cereja que, por sua amizade sincera, deram-me o suporte e a alegria nos momentos de folga.

Aos meus queridos e preciosos amigos de "Floripa" e colegas da UFSC; em especial a Dra. Ivana Fernandes e ao companheiro de lutas por uma saúde pública melhor, Dr. Valdir Ferreira.

E finalmente, aos recentes amigos de além-mar, Portugal, Nini, Pedro, Filipe, Paulo e Manuela pela acolhida e pelos longos papos temperados com vinho e fado vadio; afinal de contas, de que vale a vida senão para ser vivida? 
“O sonho pelo qual brigo,

exige que eu invente em mim

a coragem de lutar ao lado da coragem de amar".

Paulo Freire 


\section{RESUMO}

Marcellino, I. V. Da informação à educação em saúde: a CIPA e sua atividade educativa em uma empresa de Ribeirão Preto, SP. 2004. 268 f .Tese de Doutorado. Faculdade de Filosofia, Ciências e Letras de Ribeirão Preto-Universidade de São Paulo, Ribeirão Preto.

O presente trabalho visa analisar o problema da educação em saúde do trabalhador, por meio da Comissão Interna de Prevenção de Acidentes (CIPA), quanto ao desenvolvimento de conteúdos da promoção, prevenção e recuperação da saúde, em uma empresa em Ribeirão Preto, SP. Para isso, necessitamos conhecer os processos de trabalho dos diferentes setores da empresa; estudar as atribuições, a constituição da CIPA e da Semana Interna de Prevenção de Acidentes (SIPAT), seus conteúdos, através de seus documentos e as ações de educação em saúde dos "cipeiros", assim como e sua vinculação com a promoção à saúde; ainda, identificar as concepções sobre educação em saúde dos integrantes da CIPA. O quadro teórico foi o da epidemiologia social e o da teoria de Paulo Freire. Assim sendo, elegemos como sujeitos da presente investigação, um grupo de profissionais que constituem a CIPA, por entender que a questão da educação em saúde, na área da saúde do trabalhador, é função privilegiada da CIPA, e SIPAT. A metodologia foi a da pesquisa qualitativa, o estudo de caso. Por esse motivo, foram considerados como dados da pesquisa, as anotações no diário de campo da pesquisadora dos conteúdos das reuniões da CIPA; a observação dos processos de trabalho; os questionários devidamente preenchidos pelos participantes e documentos como atas de reuniões da CIPA e SIPAT. A análise temática levou às seguintes categorias: a CIPA, segundo os "cipeiros"; a educação em saúde do trabalhador na CIPA, na realidade da empresa, e a relação educação e trabalho nessa empresa, sendo que as duas últimas foram divididas em subcategorias. Os resultados da observação indicam que a empresa é de médio porte, pois conta com 308 trabalhadores e tem predomínio de atividades intensas. A CIPA constitui-se em 1997. Conta com 10 integrantes efetivos, na proporção de 4 para seis, entre indivíduos eleitos e indicados, mostrando uma desproporção já na sua organização; começou a ter reuniões periódicas e com atas, a partir do ano de 2000. Verificamos que faltou a compreensão por parte dos "cipeiros" das atribuições da CIPA, em relação à educação em saúde, bem como os conceitos básicos em saúde do trabalhador. As práticas educacionais se caracterizaram, por serem anti-dialógicas e domesticadoras, tanto nas reuniões, como nas SIPAT's. Apesar de tudo isso, os "cipeiros" conseguiram executar minimamente algumas ações educativas. Essas práticas formais e informais que buscaram contribuir para que os trabalhadores tivessem mais conhecimento sobre acidentes e sobre a saúde, não conseguiram, porém, torná-los mais conscientes efetivando, dessa maneira, a prevenção.

Palavras-chave: Educação em saúde. Prevenção de acidentes. Promoção à saúde. Saúde do trabalhador. 


\begin{abstract}
Marcellino, I. V. From information to health education: the CIPA and it educative activity at one enterprise in Ribeirão Preto-SP. 2004. $268 \mathrm{f}$.Thesis (Doctoral). Faculdade de Filosofia, Ciências e Letras de Ribeirão Preto-Universidade de São Paulo, Ribeirão Preto.
\end{abstract}

This research aims to analyze the process of workers health education, by the Internal Committee of Accident Prevention (CIPA), related to development of promotion contents, prevention and recovering of health, at one enterprise, at Ribeirão Preto, SP. To do that, we need to understand the working process of the different sections at the enterprise; to study the assignments, the composition of the CIPA and the contents of the Internal Week of Accident Prevention (SIPAT), through its documents and the actions of health education: as well as their connection with health promotion; yet, identify health education concepts of the CIPA members. Theoretical frameworks were social epidemiology and Paulo Freire's theory. Therefore, we elected as subjects in this research, a group of professionals who belong to the CIPA, because we understand that the question of health education in the subject of the worker's health, is an CIPA and SIPAT proper assignment. The methodologie used was the qualitative research, the study of a case. For that reason the research data considered were: notes on the research field diary about CIPA meetings; working process observation; questionnaires duly filled by the participants and documents as the CIPA and SIPAT meetings records. Thematic analysis generated the following categories: the CIPA, according to its members; health education by CIPA members, at the enterprise reality and the relationship between education and work on that company being the last two divided in subcategories. Results of observation show that this is a medium size enterprise; since it has 308 workers who perform intense activities. The CIPA was constituted in 1997. It has 10 effective members, 4 elected by their fellow workers and 6 chosen by the company directors, witch show a back of proportion from the beginning; the CIPA started with periodic and recorded meetings since 2000 . We verified that the CIPA members missed the comprehension about their assignments, in relation to health education, as well as about the basic concepts on workers health; the educational practices are characterized by being antidialogical and aim to domesticate other workers, either at their meetings, and at the SIPAT. In spite all that, the CIPA members managed to perform at least a few educative tasks. Those formal and non-formal practices which aimed to contribute to increase the workers knowledge about accidents and about health, did not however, make them more aware making effective, that way, the prevention.

Keywords: Health education. Accident Prevention. Health promotion. Workers health. 


\section{LISTA DE ILUSTRAÇÕES}

GRÁFICO 1. Óbitos decorrentes do Acidente de Trabalho,1996 a 2000.......45

GRÁFICO 2. Acidentes de Trabalho Incapacitantes, 1996 a 2000...................46

GRÁFICO 3. Distribuição de Acidentes do Trabalho Registrados, 2000.......46

GRÁFICO 4. Distribuição de Acidentes de Trabalho Liquidados por consequiência,

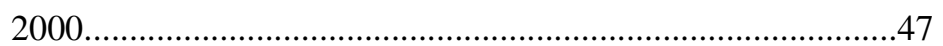

GRÁFICO 5. Principais Fatores Causais dos Acidentes de Trabalho Analisados de Janeiro a Dezembro de 2002. .54

GRÁFICO 6. Distribuição de acidentes de trabalho com afastamento de 1997 a 2002 . 106 


\section{LISTA DE TABELAS}

QUADRO 1. Morbidade e mortalidade nos ciclos de desenvolvimento e crise do

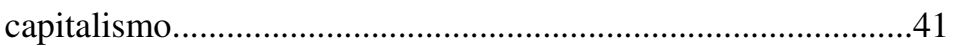

QUADRO 2. Ações de saúde, promoção e prevenção.........................................74

QUADRO 3. As categorias e as subcategorias do estudo.................................107

QUADRO4.As razões para estar na CIPA, e participação segundo os

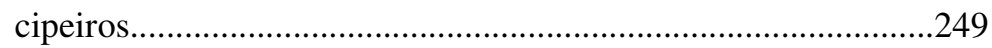

QUADRO 5.Conceito e as atribuições da CIPA, segundo os cipeiros..............250

QUADRO 6. Temas abordados nas reuniões de CIPA para desenvolvimento em atividades

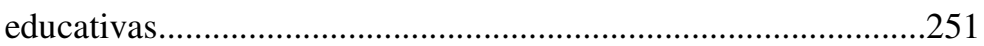

QUADRO 7. Tema-a prevenção de acidentes................................................252

QUADRO8.Os meios utilizados em educação em saúde, segundo os

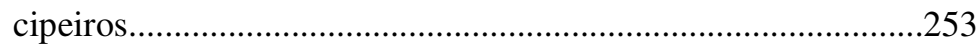

QUADRO 9. Práticas/atividades de educação formal.....................................254

QUADRO 10. Práticas/Atividades de educação informal..................................255

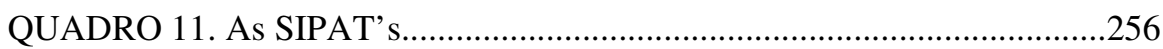

QUADRO 12. Problemas e soluções identificados na prática educativa..........258

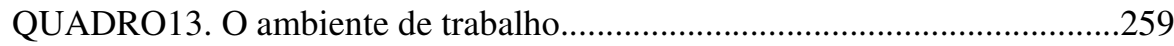

QUADRO 14. Problemas e soluções identificados no cotidiano da fábrica.....260

QUADRO 15. O SESMT em sua atividade educativa......................................261 


\section{LISTA DE SIGLAS}

$\begin{array}{ll}\text { AIDS } & \text { SÍNDROME DA IMUNO DEFICIÊNCIA ADQUIRIDA } \\ \text { CAT } & \text { Comunicação de Acidentes do Trabalho } \\ \text { CID } & \text { Código Internacional de Doenças } \\ \text { CIPA } & \text { Comissão Interna de Prevenção de Acidentes } \\ \text { CLT } & \text { Consolidação das Leis Trabalhistas } \\ \text { DIESAT } & \text { Departamento Intersindical de Estudos e Pesquisas de Saúde e dos Ambientes } \\ \text { de Trabalho } & \\ \text { DRT } & \text { Delegacia Regional do Trabalho } \\ \text { EPC } & \text { Equipamento de Proteção Coletiva } \\ \text { EPI } & \text { Equipamento de Proteção Individual } \\ \text { IBGE } & \text { Instituto Brasileiro de Geografia e Estatística } \\ \text { IEC } & \text { Informação Educação Comunicação } \\ \text { INAMPS } & \text { Instituto Nacional de Assistência e Previdência Social } \\ \text { INPS } & \text { Instituto Nacional de Previdência Social } \\ \text { INSS } & \text { Instituto Nacional de Seguridade Social } \\ \text { ISEB } & \text { Instituto Superior de Estudos Brasileiros } \\ \text { LER } & \text { Lesão por Esforço Repetitivo } \\ \text { MPAS } & \text { Ministério da Previdência e Assistência Social } \\ \text { MS } & \text { Ministério da Saúde } \\ \text { MTb } & \text { Ministério do Trabalho } \\ \text { MTbPS } & \text { Ministério do Trabalho e da Previdência e Assistência Social } \\ \text { NR } & \text { Norma Regulamentadora } \\ \text { NRR } & \text { Norma Regulamentadora Rural } \\ \text { OIT } & \text { Organização Internacional do Trabalho } \\ \text { OMS } & \text { Organização Mundial de Saúde } \\ \text { PAC } & \text { Programa de Agentes Comunitários } \\ \text { PEA } & \text { População Economicamente Ativa } \\ \text { PCMSO } & \text { Programa de Controle Médico de Saúde Ocupacional } \\ \text { PIB } & \text { Produto Interno Bruto } \\ \text { PNAD } & \text { Pesquisa Nacional por Amostra de Domicílios } \\ \text { PPRA } & \text { Programa de Prevenção de Riscos Ambientais } \\ \text { PSTs } & \text { Programas de Saúde do Trabalhador } \\ \text { SEHSMTs } & \text { Serviços Especializados em Higiene, Segurança e Medicina do Trabalho } \\ \text { SEMSATs } & \text { Semanas de Saúde do Trabalhador } \\ \text { SESMT } & \text { Serviço de Especializado em Segurança e Medicina do Trabalho } \\ \text { SIPAT } & \text { Semana Interna de Prevenção de Acidentes do Trabalho } \\ \text { SUDS } & \text { Sistema Único e Descentralizado de Saúde } \\ \text { SUS } & \text { Sistema Único de Saúde } \\ & \end{array}$




\section{SUMÁRIO}

\section{LISTA DE ILUSTRAÇÕES}

\section{LISTA DE QUADROS}

\section{RESUMO}

\section{ABSTRACT}

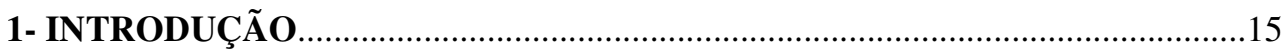

2- OBJETIVOS

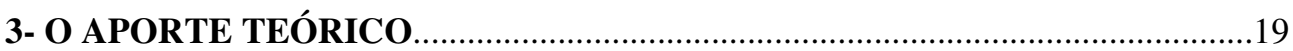

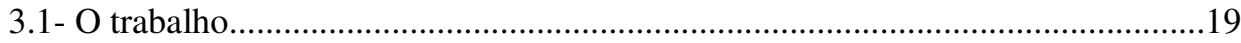

3.1.1- A globalização e a reestruturação produtiva no Brasil de hoje.....................19

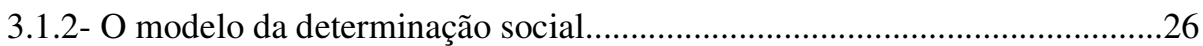

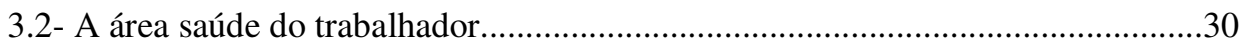

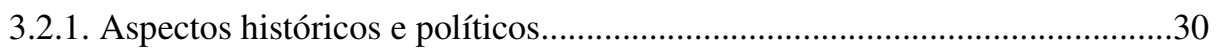

3.2.2. O perfil epidemiológico em saúde do trabalhador.......................................40

3.2.3. A CIPA: atribuições, constituição e legislação................................................48

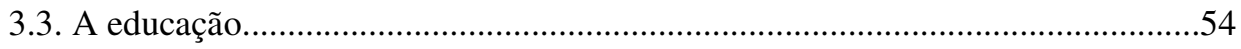

3.3.1. O modelo de Paulo Freire: as bases teóricas da educação

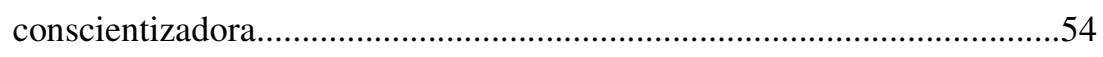

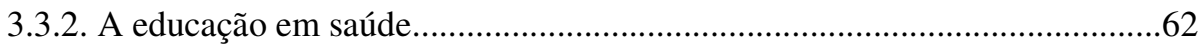

3.3.3. A educação em saúde no contexto da saúde do trabalhador: concepções e historicidade 
3.3.4. A educação como instrumento de promoção em

4- O CAMINHO TEÓRICO-METODOLóGICO......................................................76

4.1. A pesquisa qualitativa e o estudo de caso.......................................................76

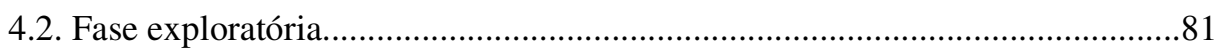

4.3.Instrumentos e procedimentos de coleta de dados.............................................83

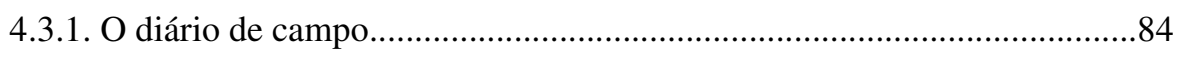

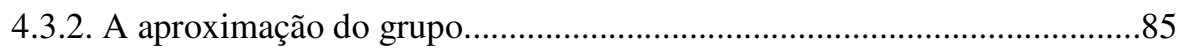

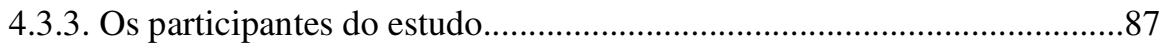

4.3.4. A observação dos processos de trabalho..................................................88

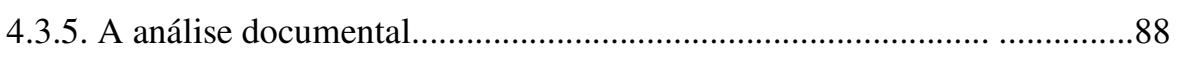

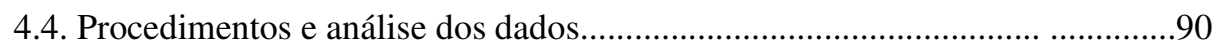

4.4.1. A organização do material recolhido e a análise de conteúdo..................90

\section{5- O PROCESSO EDUCATIVO EM SAÚDE DO TRABALHADOR EM UMA EMPRESA DE RIBEIRÃO PRETO, SÃO PAULO...........................................95}

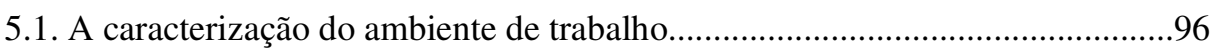

5.2. A organização da CIPA e do SESMT ………....................................................104

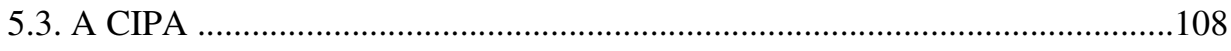

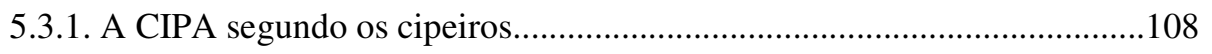

5.3.1.1. As razões para estar na CIPA, e participação segundo os

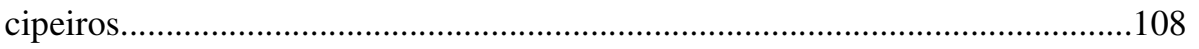

5.3.1.2. Conceito e as atribuições da CIPA, segundo os cipeiros............................111

5.3.2. A educação em saúde do trabalhador na CIPA.............................................115

5.3.2.1.Temas abordados nas reuniões de CIPA para desenvolvimento em atividades

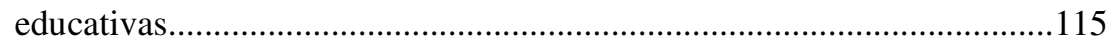

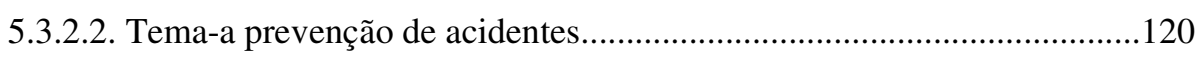


5.3.2.3.Os meios utilizados em educação em saúde, segundo os cipeiros................................................................... 125

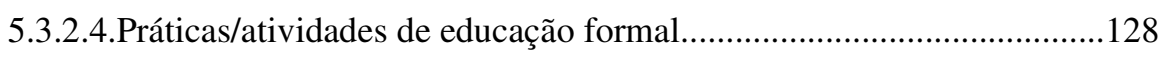

5.3.2.5.Atividades de educação informal....................................................131

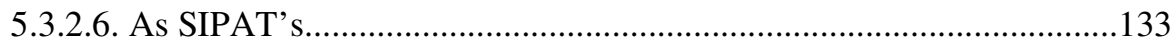

5.3.2.7. Problemas e soluções identificados na prática educativa.....................137

5.3.3. A relação educação/trabalho nessa empresa....................................141

5.3.3.1.0 ambiente de trabalho......................................................... 141

5.3.3.2.Problemas e soluções identificados no cotidiano da empresa.................................................................. 148

5.3.3.3. O SESMT na atividade educativa................................................ 151

6- CONSIDERAÇÕES FINAIS................................................................. 158

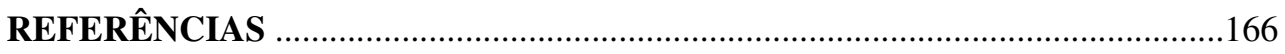

APENDICE.................................................................................................177

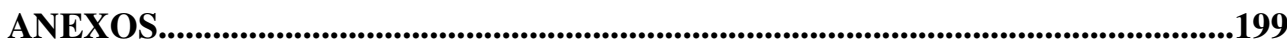




\section{1-INTRODUÇÃO}

Ao atuar como médica do trabalho, em uma empresa de Ribeirão Preto, SP, observei a importância de defender a saúde do trabalhador, em termos de detecção de agravos à sua saúde; entre eles, a falta de acesso à informação, a respeito de sua saúde. A questão posta é a de analisar o problema da educação em saúde, no contexto da saúde do trabalhador, por meio da Comissão Interna de Prevenção de Acidentes (CIPA), para o desenvolvimento de conteúdos da promoção, prevenção e recuperação da saúde no contexto de empresa.

Assim sendo, elegemos como sujeitos da presente investigação, um grupo de profissionais que constituem a CIPA, em uma empresa privada em Ribeirão Preto, por entender que a questão da educação em saúde na área da saúde do trabalhador é função

privilegiada da CIPA e da Semana Interna de Prevenção de Acidentes (SIPAT), por ela promovida anualmente.

Observa-se que as experiências na área saúde e trabalho apontam para a necessidade de estudar melhor a relação educação-saúde. Em razão disso, entendemos que os membros da CIPA seriam a instância educativa central de multiplicação de conhecimentos e práticas preventivas, uma vez que concebemos a educação como uma facilitadora da promoção em saúde. Nesse sentido, este trabalho investigativo pode contribuir para essa discussão sobre qual é o papel da CIPA no monitoramento e prevenção dos agravos à saúde, decorrentes da organização do trabalho.

Vários autores, como Buss (1999); L’Abbate (1999); Lescura e Mamede (1990); Mello, Rouquayrol e Araújo (1998); Rezende e Nascimento (1988); Rozendo et al. (1999); Rubinson e Alles (1984); Singer, Campos e Oliveira (1988); Vellozo, Martins e Nascimento 
(1999) enfatizam a vinculação existente entre saúde e educação, chamando a atenção de quem estuda o tema "educação em saúde" e de quem trabalha na área de saúde coletiva, por tratar-se de questão constante na prática concreta. Ou seja, várias questões que surgem no cotidiano de quem lida com saúde coletiva têm sua resolução ou, no mínimo um apontamento em direção à solução, na educação formal e/ou informal. Explicito aqui, então, a primeira razão da escolha do objeto de estudo, ou seja, a importância da educação em saúde na prática cotidiana da saúde coletiva.

Uma outra razão da escolha reside nas minhas próprias experiências profissionais, quais sejam, a de médica sanitarista, de médica do trabalho, de homeopata e de professora. Nessas variadas atividades, desenvolvi palestras, campanhas educativas, programa de rádio, entrevistas a jornais locais e projetos educacionais ampliados, trabalhando em equipe e com meios de comunicação diversos, abrangendo a comunicação verbal e escrita. Essas experiências, além de reafirmar meu compromisso com a saúde coletiva, mostraram a necessidade de ampliar meus conhecimentos sobre educação, fazendo-me refletir sobre o papel da educação como promotora de saúde e dos profissionais de saúde como educadores. Essas preocupações têm estado presentes em meu cotidiano de educadora; a partir delas, a utilização do conhecimento oriundo basicamente da área de saúde não tem sido suficiente, para fundamentar as concepções teóricas, dar embasamento às ações e criar condições para a intervenção nesse campo.

O objeto da investigação é a educação em saúde do trabalhador via CIPA, ou seja, o papel educativo da CIPA; neste sentido, ao pensar em educação em saúde, os conceitos que aparecem são baseados em diferentes concepções, das quais podemos citar, Buss (1999); Candeias (1997); Gadotti (1996); L’Abbate (1999); Rozendo et al. (1999); Schall (1999); Souza et al. (2003); Vasconcelos (1997); Vellozo, Martins e Nascimento (1999) entre outros. 
Para muitos, educar para a saúde é levar a compreensão dos especialistas, conscientes e politizados, para a população "ignorante", que deve mudar seus hábitos prejudiciais à saúde. Desse modo, essa população é vista como submissa e sem condições de ensinar qualquer coisa ao especialista (FREIRE, 1979, 1989a).

Porém, na concepção de Vasconcelos (1997), entre outros, a educação em saúde é entendida como uma educação baseada no diálogo, isto é, uma troca de saberes. Consiste em um intercâmbio entre o saber científico e o popular, em que cada um tem muito a ensinar e a aprender.

De fato, é nessa perspectiva que concebemos a educação em saúde, que, seria, propriamente, o processo de intervenção na realidade, na qual pudéssemos realizar observações e, conseqüentemente contribuir para a transformação das opiniões, sentimentos e valores dos consumidores do trabalho e da própria saúde.

\section{2-OBJETIVOS}

Para apreensão do processo de educação em saúde do trabalhador na CIPA de uma empresa do setor de alimentos, temos como Objetivo Geral:

Analisar se as ações de educação em saúde na empresa, se caracterizam como práticas de promoção à saúde, transformadoras da realidade concreta, via instâncias e instrumentos existentes na empresa.

\section{E como Objetivos Específicos:}

Conhecer os processos de trabalho dos diferentes setores da empresa.

Estudar as atribuições, a constituição da CIPA e SIPAT, seus conteúdos, por meio de seus documentos e das ações de educação em saúde dos "cipeiros" como também sua vinculação com a promoção à saúde. 
Identificar as concepções sobre educação em saúde dos integrantes da CIPA.

Ao longo da pesquisa, foram utilizados alguns recursos técnicos como meios de obtermos as informações. Também consideramos importante ressaltar o nosso relacionamento com várias áreas do conhecimento para a apreensão do objeto, em razão da necessidade de uma abordagem transdisciplinar para ser compreendido, dentre as quais podemos citar: a saúde coletiva, a pedagogia, o direito, a sociologia e a psicologia do trabalho.

Assim, neste capítulo (1-Introdução) trouxemos um breve histórico de minhas experiências profissionais apontando assim, as razões da escolha do objeto e apresentamos o objeto deste estudo.

O capítulo 2 contém a meta e os objetivos centrais deste trabalho investigativo.

O capítulo 3 (O aporte teórico) mostra o referencial teórico da tese. Inicialmente, escrevemos sobre o trabalho, a globalização e a reestruturação produtiva no Brasil atual, bem como sobre o modelo da determinação social, já que a metodologia dialética exige que os dados sejam compreendidos nesse contexto mais geral. Ainda, contextualizamos historicamente a área saúde do trabalhador, a elaboração das políticas nessa área, o perfil epidemiológico da área saúde do trabalhador, a CIPA nesse contexto, entendemos que tais questões são fundamentais para a compreensão do objeto: a educação em saúde do trabalhador na CIPA. E explicitamos melhor, o conceito de educação em saúde, principalmente o modelo tradicional e o inovador, o modelo Paulo Freire, como também a educação em saúde no contexto da saúde do trabalhador, afirmando ser a atividade educativa, essencialmente, uma prática de promoção á saúde.

O próximo capítulo (4- O caminho teórico-metodológico) apresentamos a pesquisa qualitativa, o estudo de caso e as fases da pesquisa: a coleta de dados, os aspectos éticos, o local da pesquisa e os sujeitos. Finalmente, a forma de análise dos dados, a análise temática. 
No quinto capítulo, apresentamos os resultados analisados à luz da teoria de Paulo Freire e do materialismo histórico e dialético, fundamentados nos dados obtidos, por meio dos discursos dos sujeitos da pesquisa, "os cipeiros", em uma empresa privada, no município de Ribeirão Preto.

No sexto capítulo, em decorrência das considerações finais deste trabalho investigativo, procuraremos resgatar os principais pontos abordados, durante o desenvolvimento da tese, buscando, com ênfase nos processos de trabalho e na educação problematizadora, apresentarmos algumas sugestões e recomendações sobre a educação em saúde do trabalhador, em uma empresa no município de Ribeirão Preto, a partir da análise da realidade empírica investigada. E, finalmente, apresentamos as referências bibliográficas, o apêndice e os anexos.

\section{3-O APORTE TEÓRICO}

\section{1- O trabalho}

\subsection{1- A globalização e a reestruturação produtiva no Brasil de hoje}

Para entendermos o papel educativo da CIPA na questão da saúde do trabalhador, é importante falarmos sobre o que está ocorrendo no mundo do trabalho.

As relações entre o trabalho e a saúde dos trabalhadores vêm ganhando, nos últimos anos, uma dimensão nova dentro do processo de globalização ou mundialização, que, segundo alguns autores, inicia o século XXI ou o terceiro milênio da era Cristã (LINO; DIAS, 1995; MENDONÇA, 2002). A nova territorialidade é marcada pelo mercado global, pela conformação de um imaginário coletivo mundializado e pelo agravamento do desemprego, da miséria, da violência e com a persistência de bolsões da fome. 
Algumas evidências já disponíveis sinalizam mudanças de tal magnitude. Por esse motivo, a globalização deixa de ser um simples conceito para se tornar o paradigma do conhecimento nos campos da Economia, da Política, da Ciência, da Cultura e da Informação.

Segundo Flecha (1996), o momento em que nos situamos corresponde a uma "passagem à pós - modernidade", que se estende desde finais dos anos sessenta e o final da prosperidade do pós-guerra na economia capitalista mundial. Encontramos também, outros termos que definem esse momento histórico, como os seguintes: pós - industrial, pós capitalista, pós - socialista, pós - burguês, pós - econômico, pós bem-estar-social, póscivilizado.

Garcia (1998), em suas considerações, diz-nos que conhecer novos paradigmas e perceber seus múltiplos reflexos nas formas de organização da sociedade humana é o desafio que se nos apresenta, visto que os enormes problemas globais e inter-relacionais, criados pelo paradigma positivista que têm norteado os últimos séculos, levam-nos ao lado do desenvolvimento tecnológico, a um afastamento essencial do ser humano.

Além desses fatores, Castells (1996) aponta que o motor para a mudança ao pósindustrialismo é uma inovação nas forças de produção. Durante a primeira metade do século $\mathrm{XX}$, a ciência e a tecnologia foram as principais fontes de produtividade. No período posterior à Segunda Guerra Mundial, o conhecimento e a informação se convertem nos elementos fundamentais de geração de riqueza e de poder na sociedade.

Gomes (2001) coloca a importância de ressaltar os dois aspectos básicos que caracterizam a revolução tecnológica atual: a) focaliza-se nos processos; b) considera a informação sua matéria prima fundamental, assim como seu principal resultado.

Dessa maneira, a informação apresenta-se como um meio e um produto desse processo chamado globalização; por esse motivo são importantes os trabalhos que discutam o papel dessa informação no contexto atual, bem como a diferença entre informar e educar. Se o 
primeiro é pontual, o segundo, é entendido como um processo dinâmico, com envolvimento das partes, cujo objetivo é a transformação.

Alves (2001), ao considerar o fenômeno da globalização, nos revela que ela é um processo sócio-histórico, caracterizada por três dimensões totalizantes e contraditórias. A primeira concebe globalização como ideologia (a sua dimensão contingente); a segunda, globalização como mundialização do capital (o seu nexo essencial e que confere sentido sócio-histórico ao processo em geral) e a terceira, globalização como processo civilizatório humano-genérico (a dimensão pressuposta e que dá ao processo de globalização uma natureza profundamente contraditória).

Daí, concluirmos que as três dimensões da globalização não podem ser separadas, porque compõem uma totalidade concreta sócio-histórica completa e integral, no sentido de: globalização como ideologia, como mundialização do capital e como processo civilizatório humano genérico, cuja tendência é a constituição de novas determinações sócio-históricas no (1) plano da ideologia e da política, (2) no plano da economia e da sociedade e (3) no plano do processo civilizatório humano-genérico, vinculado ao desenvolvimento das forças produtivas humanas (ALVES, 2001).

Diz-nos, ainda o autor que a única abordagem válida sobre o fenômeno da globalização busca apreendê-la numa perspectiva crítica (e radical), no sentido de levar-nos às verdadeiras raízes do novo fenômeno sócio-histórico (e ideológico), intrínseco à nova etapa de desenvolvimento do capitalismo mundial. Então, a globalização é um fenômeno sóciohistórico intrinsecamente contraditório e complexo, que caracteriza, sob nossa perspectiva, uma nova etapa de desenvolvimento do capitalismo moderno. Constitui resultado de múltiplas determinações sócio-históricas (e ideológicas).

Lino e Dias (1995) reafirmando esse pensamento, colocam que a globalização é um processo concentrador e excludente, concentra-se em favor de uma minoria e exclui uma 
maioria; logo, é favorável àqueles que detêm o capital e que podem aproveitar-se da especulação do mercado financeiro. Pode até favorecer um certo crescimento da produção, porém é negativa do ponto de vista do emprego, porque resulta na competitividade, na substituição da força de trabalho por equipamentos cada vez mais modernos. Estima-se que um terço do problema do desemprego vem dos exponenciais avanços tecnológicos, substituidores de homens por máquinas.

A partir de meados de 1980, é que se intensifica o processo de reestruturação produtiva, com a incorporação de novas tecnologias, intensificação do uso da informática, automação industrial e mecanização agrícola, flexibilização das relações trabalhistas, rigor no controle da qualidade e novas políticas de recursos humanos. Porém, vários estudos demonstram que, apesar de haver melhoria tecnológica, não existe correspondência junto ao trabalhador, já que houve avanço no processo de deterioração das condições de trabalho e de vida, mostrando que a política social brasileira expressou, de forma particular, as desigualdades econômicas e sociais criadas pela implantação do capitalismo (SCOPINHO; VALARELLI, 1995; MENDONÇA, 2002; SCOPINHO, 2003).

Depois dos anos 80, a "década perdida", parecia que nada mais poderia ser pior. No entanto, a mundialização de bens e capitais, sob a supremacia do capital financeiro, não trouxe a esperada riqueza das nações, e para o Brasil não foi diferente: a abertura econômica e financeira indiscriminada, sobrevalorização do real e juros elevados tiveram por conseqüência, um crescimento econômico medíocre, uma profunda desestruturação produtiva, sendo que o crescimento econômico da década de 1990 foi o menor do século XX. Os crescentes déficits da balança comercial, a transformação da estrutura do comércio exterior, a elevação líquida do setor público, baixo crescimento econômico e a especialização produtiva regressiva, com ampliação da desnacionalização, foram danosos ao emprego. Em resumo, se o desemprego e a precarização ocorrem, não têm sido por causa da inovação tecnológica e da 
produtividade, mas devido a um crescimento econômico medíocre e à estagnação do tempo de trabalho (MATTOSO, 1999).

Assim, ao analisarmos a sociedade brasileira, sob o ponto de vista do seu desenvolvimento econômico, vemos que ela sempre se caracterizou por privilegiar a produção de bens, direcionados para o mercado externo e, internamente, para a produção de bens não duráveis. Esse processo continua sendo possibilitado pela estrutura fundiária, baseada na concentração de grandes latifúndios, em mãos de uma parcela restrita da população. Esses latifúndios são utilizados, na sua maioria, para fins de especulação imobiliária e não para a produção de bens de primeira necessidade. "Em 1985, enquanto 90\% dos estabelecimentos com menos de 100 ha dispunham de apenas $21,1 \%$ da área ocupada, $1 \%$ dos estabelecimentos com mais de 1000 ha controlavam 43,9\% da área ocupada" (OLIVEIRA, 1994, p. 65). E nesta década, esses dados continuam válidos, pois nossa estrutura fundiária, pela ausência de uma política agrária que favoreça o pequeno produtor, continua privilegiando os grandes latifundiários.

Na esfera político-ideológica, presencia-se, na sociedade brasileira, cada vez mais a instituição do Estado Mínimo, em detrimento do Estado de Bem-Estar, cujas políticas direcionam-se para o livre jogo das regras de mercado (notadamente as do mercado financeiro) para o soterramento das noções básicas de cidadania, conformando o cidadão como mero consumidor (DUPAS, 1999).

A política social brasileira expressou de forma particular as conseqüências da implantação do capitalismo, criando desigualdades sociais e econômicas que conduziram ao processo de marginalização de grandes contingentes populacionais, o que caracterizou a pobreza urbana brasileira como fenômeno estrutural, expressando a baixa condição material e a não participação social (MENDONÇA, 2002). Portanto, do ponto de vista social, somos uma sociedade estratificada por classes sociais, no seio da qual manifesta-se e intensifica-se 
uma diversidade de desigualdades sociais, destacando-se os diferenciais de acesso à educação, à saúde, à habitação, ao emprego, à alimentação, entre outros. Agrava-se um conjunto de problemas sociais, como a persistência de expressivos grupos sociais sem qualificação profissional, assim como o aumento expressivo da taxa de desemprego, do mercado de trabalho informal e do ingresso da mulher, de crianças e de jovens no mercado de trabalho. Isso resulta na intensificação da exploração dos segmentos empregados e dos que trabalham, no aviltamento das políticas salariais e no agravamento dos mais diversos modos de manifestação da miséria, da violência e da exclusão social (DUPAS,1999; ANTUNES, 2000).

Podemos citar ainda, como aspectos da globalização em curso, uma organização corporativa da sociedade; políticas públicas de abertura do país à influência estrangeira; o alcance e a velocidade de transmissão da informação cada vez mais rápida; a exclusão social; mais diretamente, empregos instáveis e temporários, terceirização dos serviços, exigência de múltiplas e flexíveis qualificações para o mesmo nível salarial, diminuição crescente de salários, desemprego, ou seja, mudanças sociais, políticas, econômicas, culturais e ideológicas. Esses fatores, além de configurarem importante material ao setor, saúde e segurança no trabalho, também configuram em seu bojo uma concepção de exclusão, à medida que globalizamos conceitos, informações, mas não o desenvolvimento e a democracia. Então, de forma sucinta, temos que o Brasil viveu, ao longo deste século, uma história de crescimento econômico, geração de empregos, mobilidade social e concentração de renda, no entanto, das suas origens até os dias atuais, a sociedade brasileira conforma uma estrutura e organização sociais, sob o modo de produção capitalista, cujo desenvolvimento baseia-se em relações de dependência perante as sociedades hegemônicas, em nível mundial (IANNI, 1996; DUPAS, 1999).

Assim, o trabalho, situado no contexto atual do fenômeno da globalização, em seus aspectos sociais, políticos, ideológicos e econômicos, a despeito da reestruturação produtiva 
que se estabeleceu no Brasil, necessita de análises que reafirmem sua centralidade, pois os impactos no mundo do trabalho são cada vez mais visíveis e geram mudanças no perfil epidemiológico sobre a saúde dos trabalhadores.

Neste sentido, Lino e Dias (1995, p. 2) nos trazem,

[...] de modo sumário, entre os impactos sobre o mundo do trabalho. podem ser destacados: a introdução de tecnologias, particularmente da automação e da robótica substituindo o trabalho do homem; o declínio das atividades de manufatura e o crescimento do setor de serviços; a introdução de novos processos de produção e gestão do trabalho, gerando novos riscos para a saúde e o meio ambiente; proliferação de pequenas unidades de produção, com maior dificuldade para sua organização; aumento da mobilidade das unidades de produção e das empresas, resultando em aumento da competição global pelo emprego; aumento dos níveis de desemprego em várias regiões do globo; aumento da intensidade e duração do trabalho, levando ao aumento de stress e das doenças dele decorrentes; aumento do trabalho realizado no domicilio, do trabalho em tempo parcial e sazonal, levando à precarização do trabalho; diminuição dos níveis de remuneração e pagamento pelo trabalho realizado.

O que já podemos observar, constituindo uma preocupação crescente de âmbito mundial, é a possibilidade de uma sociedade de trabalhadores sem trabalho, gerando múltiplos problemas, decorrentes da alteração da fonte básica da identidade psicológica, de inserção social e socialização, definidas pelo trabalho remunerado, que viabiliza o acesso a bens e serviços e o exercício de direitos de cidadania, produzindo, entre outras conseqüências, novas formas de adoecimento, individual e coletivo e profundas repercussões na vida social.

Desse cenário, aparentemente desfavorável e depressivo, é importante destacarmos as contradições e conflitos existentes no interior do seu processo, que sugerem oportunidades de intervenção e de mudança social na direção de uma sociedade mais justa e eqüitativa. Entre eles, podem ser lembrados: o desenvolvimento, no âmbito do movimento social, de iniciativas, ainda que isoladas, porém fortes, de oposição e enfrentamento dessa situação; a 
possibilidade de expansão dos mercados internos e do exercício da solidariedade internacional.

\subsection{2- O modelo da determinação social}

A compreensão histórica da relação entre o processo saúde-doença e o trabalho é de fundamental importância para quem deseja entender a área da saúde do trabalhador.

Em cada período histórico, a organização da sociedade deu-se de maneira diferente e as explicações para os fatos foram influenciadas por essas conformidades. Dentro desse contexto, a busca do entendimento da saúde e do ato de adoecer passaram por diversas fases, desde explicação mágico-religiosa, naturalista, religiosa-cristã, até chegarem ao cientificísmo.

Consta que o modelo hegemônico é o da visão de saúde como simples ausência de doenças, tendo se adequado à visão clássica e positivista da medicina. Para explicar os fatos, recorre-se a uma visão de mundo fragmentada, em que é prejudicada a noção do indivíduo como totalidade e da vida como processo.

Temos a acrescentar que vários outros modelos foram propostos, no sentido de tentar entender esses fenômenos; entre eles, o modelo da determinação social, abordagem que pressupõe relações homem-natureza, homem, normas e valores sociais, mediadas pela categoria trabalho, numa determinada sociedade. Tal modelo foi e vem sendo estudado por diversos teóricos, especialmente na América Latina, e fundamenta a área de saúde do trabalhador, incorporando o conceito de processo de trabalho como categoria central.

Se tomarmos, como questão central o trabalho, ato criativo e de desenvolvimento das potencialidades humanas, cujos elementos constituintes do processo são os objetos, os instrumentos materiais/intelectuais (saberes) e a força de trabalho, ou atividade humana, ele (o trabalho) constitui, a própria realidade humana, ou seja, é através dele que o homem cria 
condições de existência, transformando a natureza e criando, portanto, a cultura e um mundo humano. Progressivamente, ele vai se desenvolvendo, seja tecnicamente, intelectualmente, ou em nível sócio-pessoal.

Seria fácil, desse modo, prever como o trabalho, assim concebido, poderia ser um potencializador de nossas criatividades. Entretanto, se vê que, no modo de produção capitalista, o trabalhador não domina o seu próprio trabalho, o que se traduz pela organização, processo e jornada de trabalho inadequados. Torna-se importante verificar que somente a socialização dos meios de produção, colocando todo serviço a favor da coletividade, seria um processo libertador e conscientizador. Mais uma vez, vê-se que isso não ocorre na sociedade capitalista, distorcida, contraditória e alienada.

O modo de produção capitalista surge num determinado contexto histórico e caracteriza-se basicamente pela acumulação do capital que se materializa na produção de mercadorias e de mais-valia, absoluta ou relativa. Verifica-se que o homem, por meio do seu trabalho, é que vai garantir a manutenção desse capital. Isto traz várias consequiências; entre elas, as formas de adoecer, relacionadas à organização do trabalho.

Segundo Laurell (1982, p. 23),

O processo saúde-doença é determinado pelo modo como o homem se apropria da natureza em um dado momento, apropriação que se realiza por meio do processo de trabalho baseado em determinado grau de desenvolvimento das forças produtivas e relações sociais de produção.

Com isso, Laurell quer nos mostrar que a doença faz parte de um processo que é socialmente determinado pelas condições materiais de uma dada sociedade, ou coletividade. A autora baseia esta teoria, no fato dos diferentes padrões de adoecimento, morbidade, de uma coletividade, seja em diferentes ou no mesmo momento histórico. Apesar disso, não desconsidera a importância de outros fatores, fora do espaço do processo de produção. 
Essa concepção, por sua vez, concebe o trabalho como fator de desenvolvimento das potencialidades do homem e não como sinônimo de ocupação e vê a categoria trabalho como fundamento da sociabilidade humana, assumindo, portanto, grande importância nos processos de crescimento e desenvolvimento do ser humano, ou seja, da própria vida.

Segundo Valente (1991, p. 3): "Entretanto, análises apontam que, na sociedade brasileira, o trabalho acaba sendo mais um fator impeditivo do desenvolvimento das potencialidades do ser humano do que de favorecimento de seu desenvolvimento". Na área da saúde do trabalhador, tal fato manifesta-se claramente, por meio dos acidentes de trabalho, entre outros.

Vários outros estudos mostraram a relação existente entre saúde e trabalho e a relação entre o modo de produção capitalista e o adoecimento, entre eles, destacamos: Alessi et al. (1994); Berlinguer (1983); Dejours (1992); Laurell (1982); Mendes (1989); Nogueira (1982); Pinheiro (1992); Ramazzini (1985); Scopinho (2000,2003).

O modelo biologicista, hegemônico, concebe que existem riscos no trabalho, aos quais estamos sempre expostos. Sabe-se que o conceito de riscos refere-se à probabilidade de ocorrência de um evento que pode proporcionar perdas ou ganhos a um sistema ou processo produtivo (PACHIR, 2002); especificamente no âmbito da segurança e saúde do trabalho, os riscos estão relacionados aos agentes físicos, químicos, biológicos, mecânicos, ergonômicos e de acidentes.

Já o modelo da determinação social, a epidemiologia social, concebe a presença de cargas no lugar de riscos, sendo que o segundo conceito é dinâmico e relaciona cargas físicas, químicas, biológicas e mecânicas, às cargas fisiológicas e psíquicas; este modelo ainda considera desgaste em contraposição à doença. No primeiro, o processo, mais uma vez, é dinâmico, relaciona-se entre si, sendo reversível, isto é, o entendimento sobre as doenças e os acidentes do trabalho, à luz do modelo de determinação social, considera que os acidentes, por 
exemplo, não constituem questão de responsabilidade individual, mas sim decorrem de condições inseguras, insalubres e penosas, presentes nos ambientes de trabalho.

Nesse sentido, o paradigma da epidemiologia social considera as doenças e os acidentes do trabalho como danos à saúde repentinos ou não, que se originam nos processos de trabalho. O trabalho em si, articulado aos objetos, instrumentos de trabalho e modos de organização social, inerentes a determinados modos de produção, é que determinam a ocorrência ou não de acidentes, resultando em comprometimentos do desenvolvimento das potencialidades humanas (LAURELL; NORIEGA, 1989; ALESSI; SCOPINHO,1994; DIAS, 1994).

Segundo Pinheiro (1992), existe uma grande variedade de doenças que afetam os trabalhadores, sobressaindo as intoxicações crônicas e seus agravantes nos aparelhos gastrointestinal e cardiovascular, a fadiga crônica, as alterações do ciclo circadiano e seus correlatos psicossomáticos. Existem, ainda, inúmeros tipos de acidentes do trabalho que são resultantes da interação do conjunto de cargas laborais existentes no ambiente de trabalho industrial.

Outros autores como Cohn et al. (1985, p. 54) alertam para as conseqüências dos acidentes para os trabalhadores:

$\mathrm{O}$ acidentado, qualquer que seja a gravidade do acidente, passa a ser estigmatizado, isto é, tem preferência nas levas de dispensa que a empresa promove regular ou conjunturalmente. Nestas condições, se o acidente é leve, o acidentado nem se apresenta, só o fazendo nos casos mais graves que resultam em incapacidade permanente ou invalidez.

Diante disso, queremos dizer que tanto as doenças, quanto os acidentes do trabalho trazem sérias consequiências à vida do trabalhador, reafirmando a relação existente entre saúde e trabalho, e a relação entre o modo de produção capitalista e o adoecer. Porém, torna-se importante dizer que não vemos a organização do trabalho como forma de dominação do 
capital, mas também como modo de socialização e de luta dos trabalhadores pelo controle das condições de trabalho. Nesse aspecto, a relação capital-trabalho também fornece aos trabalhadores instrumentos de luta contra o poder dominante; entre outros, podemos aqui citar a CIPA, como um importante instrumento, que pode fazer frente às condições inadequadas da organização do trabalho.

\section{2 - A área saúde do trabalhador}

\subsection{1- Aspectos histórico- políticos}

No âmbito do processo de elaboração das políticas de saúde e segurança no trabalho da sociedade brasileira, percebe-se que elas foram instituídas, articuladas às esferas política, econômica, social e ideológica. Por esse motivo, com as mudanças nessas esferas alteram as conquistas sociais, mas beneficiam as categorias de maior interesse do capital e também as mais organizadas, segundo (FALEIROS, 1992).

Esse autor analisa o processo de elaboração das políticas em saúde do trabalhador no Brasil, de 1919 a 1980, dizendo-nos que, no período colonial, a política de segurança no trabalho e de saúde do trabalhador esteve ligada a ações de cunho paternalista, tanto no âmbito individual como no institucional.

Segundo esse autor, durante a Velha República, a luta entre os interesses da oligarquia e os da burguesia industrial nascente polarizou-se entre o liberalismo, o protecionismo e a repressão. Em relação à questão acidentária, o paternalismo traduzia-se nas articulações entre Empresa-Santa Casa; o liberalismo manifestava-se no seguro acidente restrito às Empresas, e a repressão traduzia-se nas articulações entre Empresa-Estado. Nota-se que o Estado garantia a assistência geral ao acidentado e mecanismos de repressão, para que não ocorressem novos acidentes, porém não interferia na questão do seguro acidente, mantido pela iniciativa privada. Essa política combinava-se com a coerção, no recinto da Empresa, para manter a 
subordinação do operário. A prática da repressão, ao lado das precárias condições de trabalho, contribuíam para o aumento da ocorrência de acidentes e o seu agravamento.

De 1937 a 1945, não houve parlamento, período este designado por Estado Novo. A ditadura instaurada proibiu as greves e institucionalizou-se o peleguismo, termo utilizado para designar o líder sindical que amortecia os choques entre patrões e operários. Em 1945, Getúlio sanciona a Consolidação das Leis do Trabalho (CLT), as primeiras normas de higiene e segurança no trabalho, destacando-se a regulamentação das comissões internas de prevenção de acidentes (CIPA's). Com esse ato, Vargas colocou-se como o benfeitor da classe trabalhadora (FALEIROS, 1992).

Durante o Estado Populista, presenciou-se a intensificação dos processos de urbanização e industrialização, sendo a política de produção, baseada no aumento da produtividade (FALEIROS, 1992). A estrutura industrial brasileira modificou-se significativamente, a partir dos anos 60, com o aumento do ingresso de capital estrangeiro, a transformação do processo de acumulação, baseado, prioritariamente, na produção de bens de consumo duráveis, produtos semi-elaborados para exportação e intensificação da produtividade do trabalho.

Com as Leis de 1976 (previdência social), e de 1977 (prevenção), complementadas com as normas regulamentadoras (NR) de prevenção de 1978, confirmou-se a articulação de um complexo sócio-industrial, estabelecido pelo governo autoritário-arbitrário, visando às políticas de retorno ao trabalho, ao aumento da produtividade, à diminuição dos custos da previdência, diminuição dos custos da produção, passando pela profissionalização da prevenção (FALEIROS, 1992). Aqui cabe destacar que as normas regulamentadoras rurais (NRR) só surgiram 10 anos mais tarde, isto é, em 1988.

Observou-se até aqui, num primeiro momento, a combinação do seguro privado com a assistência pública para que, nos anos 70 , fosse transformado em seguro público com 
assistência privada (FALEIROS, 1992). Essas mudanças processaram-se em diferentes conjunturas, fazendo-se presentes na sociedade brasileira.

Lacaz (1995) faz uma análise das políticas na área de saúde do trabalhador, de 1970 até meados de 1990. Coloca o autor que, no Brasil, os indicadores mais comuns, referentes aos efeitos do trabalho sobre a saúde são os dados de doenças profissionais, acidentes do trabalho, incapacidades e mortes por eles provocadas.

No ano de 1970, a Organização Internacional do Trabalho (OIT) concedeu ao Brasil o lamentável título de campeão mundial de acidentes do trabalho.

Neste sentido, Lacaz (1995, p. 131) revela que,

[...] apesar destas estatísticas de acidentes serem notoriamente subestimadas entre nós, foi justamente o nível que atingiram no início da década de 70 que levou a que as autoridades do então Ministério do Trabalho e Previdência Social (MTbPS) tomassem medidas visando à redução do seu número.

Para fazer frente às críticas externas, o Governo militar adota, como principal medida, a Portaria $\mathrm{n}^{\circ} .3237$, de 27/07/1972 do MTbPS, a qual obrigava as empresas a criarem os Serviços Especializados de Higiene, Segurança e Medicina do Trabalho (SEHSMT's), dimensionados pelo número de profissionais da área de medicina, enfermagem do trabalho, engenharia e de técnicos de segurança. Isso deveria se realizar, de acordo com o número de trabalhadores, em função da freqüência de acidentes do trabalho ocorridos, isto é, do "grau de risco". Porém, essa portaria não entrou em vigor e foi modificada, em 1975, pelo Ministério do Trabalho (MTb), recém-criado na época, por meio da Portaria n ${ }^{\circ} .3460$ de 31/12/1975. Em conseqüência foram alteradas as exigências, quanto ao dimensionamento do número de técnicos dos SEHSMT's; logo, esse número foi reduzido (LACAZ, 1995).

Segundo Possas (1981 apud LACAZ, 1995 p.132) ${ }^{1}$, após o ano de 1975, quando efetivamente os SEHSMTs foram criados, inicia-se todo um posicionamento ideológico das 
autoridades do MTb, no sentido de demonstrar que a implantação dos Serviços tinha tido importância fundamental para a melhoria das condições de saúde e segurança no trabalho; conseqüentemente, isso explicava a queda do número de acidentes de trabalho, conforme registraram as estatísticas oficiais da Previdência Social, a partir de 1976.

Porém, essa autora nos coloca que esta diminuição ou "ocultação" esteve mais ligada ao fato de as empresas terem assumido o custo pelos primeiros quinze dias do acidente, sendo que os dias subseqüentes ficaram a cargo da Previdência Social.

Destacamos que esta portaria é substituída pela Portaria do MTb $\mathrm{n}^{\circ} 3214$, de 08/06/1978 que cria os Serviços Especializados em Segurança e Medicina do Trabalho (SESMT's) e que está em vigor até os dias atuais.

Lacaz (1995) revela que, no plano do registro, para a definição de um perfil epidemiológico em saúde do trabalhador, temos que, no caso do Brasil e, mais especificamente, do Estado de São Paulo, o número de casos de incapacidades permanentes para o trabalho e mortes conseqüentes aos acidentes do trabalho, quando relacionados ao número total de acidentes registrados, aumentaram ou se mantiveram. Isso desmente as afirmações oficiais de que estaria ocorrendo uma melhoria da segurança no trabalho. Assim como leva-nos a observar que a agressividade e a insegurança dos locais de trabalho provocaram o aparecimento de uma verdadeira legião de inválidos.

Esse autor faz ainda um breve comentário sobre os acidentes chamados de trajeto, definidos como aqueles que ocorrem no trajeto casa-trabalho e vice-versa. Após um aumento de sua freqüência, do início dos anos 70 até 1986, verificou-se, a partir de 1987, uma diminuição incompatível com o crescente registro de acidentes de trânsito no país. Segundo dados conservadores, chegam a provocar cerca de 25.000 mortes por ano. Também aqui o sub-registro é notório, e vem se acentuando, a partir de 1987, quando os hospitais, até então credenciados pela Previdência Social, se descrenciaram do Sistema Único Descentralizado de 
Saúde (SUDS). Alegavam pagamento abaixo dos gastos reais, quando se passou a pagar de maneira indiferenciada ao atendimento dos acidentes, quer fossem do trabalho ou não, numa medida correta, conforme os princípios do Sistema Único de Saúde (SUS).

Se, no que diz respeito aos acidentes do trabalho (típicos), o quadro é preocupante, no que se refere às doenças profissionais, a situação é totalmente irreal, visto o número irrisório de casos registrados anualmente pela Previdência Social. Neste sentido, o mesmo autor alerta para o fato de que o reduzido número de doenças profissionais, comparado com a magnitude da ocorrência de acidentes do trabalho, tem relação com o fato de ser monopólio dos serviços médicos das empresas e dos convênios médicos, a assistência ao trabalhador da média e grande empresas; para as pequenas empresas, a atuação fica a cargo da Previdência Social, que tem se caracterizado pela inexistência de programas que visem ao diagnóstico, tratamento e prevenção das doenças relacionadas com o trabalho. Diz ainda que, tudo isso resulta do não envolvimento dos serviços da rede de saúde pública às atividades voltadas para os problemas de saúde, conseqüentes das condições insalubres e inseguras de trabalho, os quais assumem, nessa época, caráter de verdadeiros problemas de saúde coletiva no Brasil.

Santos et al. (1990, apud LACAZ, 1995 p. 131) ${ }^{2}$ nos dizem que,

Frise-se que, no ano de 1980, estudo da Organização Internacional do Trabalho (OIT), mostrava que o Brasil, comparado com outros países industrializados, apresentava o maior número de óbitos na População Economicamente Ativa (PEA), o que evidenciava a alta periculosidade das condições e ambientes de trabalho.

Observa-se que, a partir de 1985, ano em que se implanta a experiência dos Programas de Saúde dos Trabalhadores na rede de serviços de saúde das Secretarias Estaduais (e Municipais) de Saúde do Estado de São Paulo e Minas Gerais, houve um aumento importante de notificações de doenças profissionais; em 1988, como resultado do desaparecimento ou do "redirecionamento" das experiências na conjuntura das novas 
Administrações Estaduais eleitas em 1986, há uma tendência à queda das notificações (LACAZ, 1995).

Consideramos importante ressaltar o fato de que, a partir de 1989, vários municípios implantam experiências programáticas próprias, voltadas para a atenção à saúde dos trabalhadores em suas redes de serviços de saúde pública, ou municipalizam experiências já desenvolvidas pela rede estadual, o que leva ao aumento do registro de doenças profissionais, como se verifica no Estado de São Paulo nos anos 1990 a 1994.

Assim, duas das principais explicações para o aumento de registros de doenças profissionais no Brasil, devem-se aos Programas de Saúde do Trabalhador (PST's), e também ao reconhecimento, por parte da Previdência Social, de doenças anteriormente não consideradas como relacionadas ao trabalho, particularmente as tendinites e tenossinovites, conhecidas no Brasil com o nome genérico de Lesões por Esforços Repetitivos (LER); hoje, um problema de saúde para muitas categorias de trabalhadores, seja da indústria, como do setor agrícola ou de serviços (LACAZ, 1995).

Do ponto de vista jurídico, a Lei $\mathrm{n}^{\circ} .8213$, de 24.07.91, em seu artigo 19, estabelece que

Acidente do Trabalho é o que ocorre pelo exercício do trabalho a serviço da empresa ou pelo exercício do trabalho dos segurados referidos no inciso VII do artigo 11 desta Lei, provocando lesão corporal ou perturbação funcional que cause a morte ou a perda ou redução, permanente ou temporária, da capacidade para o trabalho (BRASIL, 1991a, p. 65).

Essa definição legal considera os seguintes tipos de acidentes do trabalho: os típicos de processos laborais, derivados da exposição de trabalhadores a grupos de riscos específicos (total de 5 grupos de riscos), e os de "trajeto", ocorridos no caminho da residência ao trabalho e vice-versa, conforme um trajeto previamente determinado. 
Segundo Lacaz (1995, p. 135), do quadro até aqui apresentado, as seguintes questões merecem atenção;

a) as empresas mantêm o controle da saúde dos trabalhadores por delegação do Estado; b) os indicadores da relação saúde-trabalho entre nós - acidentes do trabalho e doenças - são subestimados e tal fato tem estreito vínculo com $\mathrm{o}$ item anterior e, c) o Estado brasileiro delegou às empresas o controle da saúde dos trabalhadores, e sua atuação na área resume-se ao papel normatizador e fiscalizador das condições de trabalho nocivas à saúde, o que executa de forma extremamente falha e descontínua, através do Ministério do Trabalho e da Previdência Social, havendo pouco envolvimento do setor saúde com o problema, até meados dos 80 .

Ainda, segundo esse autor, o aspecto mais importante a se considerar no Brasil, nesse período, foi a maior participação do movimento sindical, lutando pela melhoria das condições de trabalho e defesa da saúde, a partir do final da década de 70, nessa época os sindicatos retomam à cena política, após anos de resistência surda à repressão; isso é consubstanciado por ações políticas claras.

Lacaz (1995) coloca ainda que, a partir da decisão da Plenária Final da II Conferência Nacional de Saúde do Trabalhador, realizada em março de 1994, como um espaço representativo das forças sociais interessadas na questão, definiu-se a unificação no SUS de todas as ações de saúde do trabalhador, relativas à questão do diagnóstico, tratamento, fiscalização/prevenção, normalização e reabilitação, segundo seus princípios e diretrizes, quais sejam: a universalidade da atenção, a descentralização/municipalização, o atendimento integral e a participação da comunidade. Por conseqüência, expressou-se claramente uma situação de competição conflitiva entre os órgãos do Governo, fragmentando ainda mais as ações do Estado. Essa situação é facilitada pela própria fragilidade da Divisão de Saúde do Trabalhador do Ministério da Saúde e também pela crise de identidade e de concretização do SUS, neste momento. 
Cabe aqui ressaltar que, nessa década, o Ministério do Trabalho (MTb), por meio das Normas Regulamentadoras (NR's) 7 e 9, cria o Programa de Controle Médico de Saúde Ocupacional (PCMSO) e o Programa de Prevenção de Riscos Ambientais (PPRA) respectivamente.

Oliveira e Vasconcelos (2000), ao analisarem brevemente a evolução da área saúde do trabalhador no Brasil, destacam a ausência de uma política pública integrada e integralizadora, a despeito de quaisquer iniciativas; isso reafirma as considerações já feitas anteriormente.

Esses autores revelam que a evolução pragmática do campo de saúde do trabalhador tem sido lenta e caracterizada por poucos avanços e muitos retrocessos. Sendo que, nos anos 80, começa a tomar forma mais definida; porém, isso se efetiva somente nos anos 90, com a criação da Comissão Interministerial de Saúde do Trabalhador, instituída pela Portaria Interministerial $\mathrm{n}^{\circ}$ 01, de 20/04/93, que propunha uma atuação conjunta do Ministério do Trabalho, da Saúde e da Previdência social, como também a Portaria MS nº 545 , de 20/05/93, que ressaltava a necessidade de integração institucional, somadas pela realização da II Conferência Nacional de Saúde do trabalhador, em março de 1994. Em resumo, técnicos, pesquisadores, trabalhadores, sindicatos e ouitros atores institucionais provocaram o Estado brasileiro afim de que elaborasse uma política nacional de saúde do trabalhador, centrada na conquista da cidadania no trabalho.

Torna-se necessário ressaltar que os autores afirmam que, a despeito do esforço de se traçar uma política nacional de saúde do trabalhador coerente com o seu ideário, chegava-se ao fim da década (e do milênio), sem ter o desenho dessa política definida e pronta para que pudesse ser praticada (OLIVEIRA e VASCONCELOS, 2000).

Atualmente, a sociedade brasileira passa por uma reforma do Estado, destacando-se a revisão da legislação sanitária, trabalhista e previdenciária, com ênfase no direito à saúde 
universalizado (Lei $\mathrm{n}^{\circ}$. 8080/90). Em contrapartida, as ações de vigilância ainda não incorporam ações em saúde do trabalhador; as NR's são conservadoramente transformadas, à medida que a noção de risco ainda predomina em seus conteúdos. Sabe-se que a flexibilização em curso dos direitos trabalhistas e o Estado neoliberal têm favorecido os debates e as propostas de privatização da Previdência Social (SCOPINHO, 2000).

No tocante à legislação trabalhista, a CLT tem-se o seu capítulo sobre as normas regulamentadoras do trabalho (NR's), dentre as quais destacamos, dada a importância para a área de saúde e segurança, a: NR-4, que trata da composição e funcionamento do SESMT e do Serviço Especializado de Segurança; NR-5, que trata da composição e funcionamento da Comissão Interna de Prevenção de Acidentes (CIPA); NR-7, que trata da elaboração e implementação do Programa de Controle Médico e Saúde Ocupacional (PCMSO); NR-9, que trata da elaboração e implementação do Programa de Prevenção de Riscos Ambientais (PPRA); NR-15, que trata de atividades e operações insalubres e NR-16, que trata de atividades e operações perigosas (BRASIL, 2000 a).

Cabe ainda ressaltar que em 2003/2004, no mundo do trabalho, ocorreram as seguintes mudanças: o Ministério do Trabalho prepara o Fórum Nacional do Trabalho e a III Conferência Nacional de Saúde do trabalhador; a revisão da NR-4 (SESMT) e da NR-5 (CIPA); mudanças na NR-17 (Ergonomia) e NR-32 (Serviços de Saúde); a Previdência Social programa o Perfil Profissiográfico (PPP) para o período; o Ministério da Saúde, através da Portaria $n^{\circ} 777$ de 28/04/2004 dita procedimentos para a notificação de agravos à saúde do trabalhador, enquanto, ainda, o Ministério da Saúde e a Comissão de Ética Médica discutem o prontuário médico eletrônico.

Não obstante o conhecimento da atuação do Estado, em relação às providências a serem tomadas no campo da saúde e trabalho, concordamos com Scopinho (2003), quando nos revela que o Estado, apesar de garantir alguns direitos aos trabalhadores, também 
flexibiliza cada vez mais a legislação trabalhista, traduzindo assim uma postura em relação à saúde e à segurança no trabalho, no mínimo contraditória.

Podemos dizer que, em função da crise de mobilização da sociedade civil, influenciada pela ameaça de desemprego ou de "precarização" do trabalho crescentes, assim como o "enxugamento" do Estado, em face das políticas neoliberais, somadas à própria crise financeira estrutural do setor saúde, apontamos alguns possíveis retrocessos na área da saúde no trabalho, entre eles: o subemprego, o desemprego, a conseqüente flexibilização das relações trabalhistas, um enfraquecimento do poder sindical, entre outras.

Isso também pode ser visualizado, em relação à atenção da saúde, onde houve a intensificação do modelo de atenção individual e curativo, em detrimento das ações de cunho preventivo; ainda a incorporação de novas tecnologias, geralmente importadas, fortalecendo a medicina científica ocidental; o enfraquecimento das políticas sociais, dificultando o pleno exercício da cidadania; a incorporação de um conceito de saúde fragmentado; dificuldade de acesso à cultura e uma dissociação no entendimento da questão ambiental, separando-os da questão da saúde, bem como incorporação de valores importados; e finalmente a inclusão dos contratos de trabalho temporários, terceirizações, desemprego, ou seja, um mercado de trabalho marcado por alterações de natureza psico-social (FÓRUM SOCIAL MUNDIAL, 2002).

Destacamos que esses fatores levaram a mudanças da situação atual de saúde da população brasileira; entre elas, podemos citar: uma crescente urbanização; um aumento da pobreza metropolitana; conseqüente repercussão sobre a saúde dos trabalhadores, entre outras, aumento do desemprego e do "exército social de reserva"; aculturação; aumento da exclusão ao acesso de bens e serviços, tais como moradia, transporte, vestuário, alimentação, lazer e cultura; mudança no perfil de morbi-mortalidade; aparecimento das doenças emergentes e reaparecimento das ressurgentes, e inclusive, alterações comportamentais, no estilo de vida e 
das questões éticas em nossa sociedade, conforme veremos a seguir, ao abordarmos a epidemiologia em saúde do trabalhador.

\subsection{2- O perfil epidemiológico em saúde do trabalhador}

Para traçarmos um perfil na área da saúde do trabalhador, iremos nos valer de dados dos Ministérios da Saúde, da Previdência Social e do Trabalho, e, ainda, de dados do Instituto Brasileiro de Geografia e Estatística (IBGE).

Em relação à saúde da população brasileira, dados sobre a morbi-mortalidade do Ministério da Saúde, referentes ao ano de 2000, nos levam à conclusão de que, apesar do aumento da expectativa de vida, a população brasileira ainda sofre de males preveníveis e evitáveis, como as doenças cardíacas e infecto-contagiosas, havendo assim necessidade de políticas públicas nos campos da saúde, educação e trabalho, bem como investimentos na promoção e prevenção de agravos (BRASIL, 2000 b).

Os dados sobre o Produto Interno Bruto, desemprego, trabalho infantil, razão de renda, proporção de pobres, analfabetismo e anos de estudo da população, obtidos pelo IBGE em 2000, traçam o perfil sócio-econômico da população. Esses dados complementam o estudo da situação de saúde nas diversas regiões do país, mostrando-nos que a política econômica, adotada até essa época, levou a crescimento econômico insuficiente, aumento do desemprego

e das desigualdades sociais (INSTITUTO BRASILEIRO DE GEOGRAFIA E ESTATÍSTICA, 2000).

Ao buscarmos compreender o perfil epidemiológico na área saúde e trabalho, percebemos que este também está intimamente ligado aos aspectos político-ideológicos, econômicos e sociais, portanto, mantém interface direta com as fases do capitalismo, como podemos visualizar esquematicamente através do quadro 1 . 


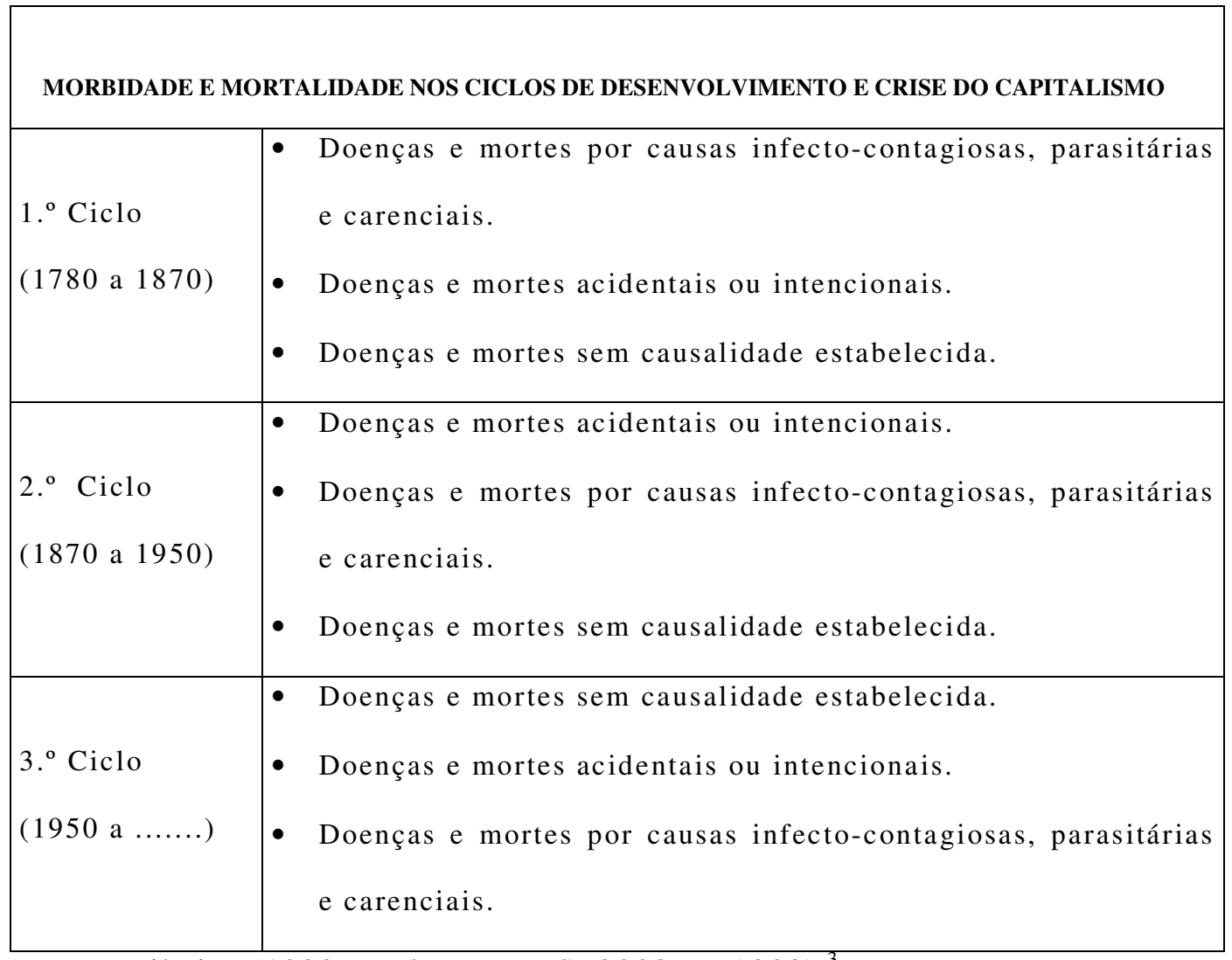

Fonte: Ribeiro (1999 apud MENDES, 2003, p. 1903) ${ }^{3}$

Quadro 1 Morbidade e mortalidade nos ciclos de desenvolvimento e crise do capitalismo

O quadro acima relaciona os três ciclos do capitalismo, com as mudanças no perfil de adoecimento e morte nos países industrializados. No Brasil, porém, essa relação não é tão visível, por termos um capitalismo tardio e uma diferença de classes muito acentuada. Apesar disso, mesmo assim, podemos estabelecer o seguinte paralelo: de 1890-1930, passamos do trabalho escravo à instalação da indústria têxtil no país, período marcada pelo predomínio das doenças carenciais e transmissíveis; de 1930-1970, entrada das indústrias pesadas de siderurgia e metalurgia, petroquímica e de transportes, com predomínio de doenças e mortes 
acidentais; e finalmente, de 1970 até nossos dias, a introdução da mecanização, da microeletrônica e da informática, passando a predominar as de curso lento, sem causas estabelecidas, muitas classificadas erroneamente, segundo o autor, como crônicodegenerativas.

Ao relacionarmos as fases do capitalismo às formas de adoecimento da classe trabalhadora, reafirmamos que o modo de organização do trabalho pode ser fator de desgaste e de adoecimento. Lino e Dias (1995) revelam que os antigos processos apresentavam fatores de stress, que se traduziam na organização do trabalho na forma da monotonia, tarefas repetitivas, eliminando a capacidade de inovação e criação dos trabalhadores. Mais recentemente, podemos dizer que os novos sistemas de produção trazem outros incentivos, porém introduzem outros fatores de stress, particularmente a insegurança e a competição.

Dentre os problemas de saúde-doença dos trabalhadores, relacionados às condições de trabalho e meio ambiente, merecem destaque a persistência de altos índices de doenças, relacionadas ao trabalho e a acidentes, socialmente distribuídos de modo desigual. Os autores nos revelam ainda que os estudos apontam que, em relação aos impactos, têm sido observadas universalmente verdadeiras epidemias das doenças ocupacionais, por movimentos repetitivos, incluídas no grupo das Lesões por Esforços Repetitivos (LER). E que outras doenças, pouco específicas e mal conhecidas, têm aparecido, sob a forma discreta ou de graves manifestações, stress ou de sofrimento psíquico, decorrentes das novas exigências impostas aos trabalhadores, bem como necessidade de mais atenção, disponibilidade e responsabilidade por toda uma linha de produção (LINO; DIAS, 1995).

Nesse sentido, o próprio Ministério da Saúde, em 1999, considera importante a definição de um perfil epidemiológico da população trabalhadora, para traçar políticas públicas no campo da saúde do trabalhador. Por esse motivo, publica a Lista de Doenças Relacionadas ao Trabalho, através da Portaria n 1339 do Ministério da Saúde de 18/11/99 
(APÊNDICE A). Mais recentemente a Portaria $n^{\circ}$ 777/GM do Ministério da Saúde de 28/04/2004, dispõe sobre os procedimentos técnicos para a notificação compulsória de agravos à saúde do trabalhador, em rede de serviços sentinela específica no SUS. Essas duas medidas fazem parte da Lei Orgânica de Saúde de n 8080/90, sobre as competências e responsabilidades do SUS. Apesar de os avanços trazidos pelas Portarias, não podemos nos esquecer de mencionar as dificuldades à sua implantação. Se não se conhece de fato os principais agravos à saúde do trabalhador, como por exemplo, os acidentes do trabalho, em razão de as dificuldades já apresentadas, então o que dizer das doenças mentais e do novo perfil de adoecimento dos trabalhadores?

Mais especificamente, quanto aos acidentes do trabalho, dados da Organização Mundial de Saúde (OMS) (1994) mostram que 120 milhões de pessoas sofrem acidentes do trabalho, 200 mil pessoas morrem anualmente em decorrência de acidentes do trabalho, em todo o mundo; a cada 3 minutos, morre um trabalhador, vítima de acidente no local de trabalho; a cada segundo, pelo menos 4 trabalhadores sofrem lesões; o local de trabalho pode ser considerado um dos ambientes mais perigosos. De $30 \%$ a $50 \%$ dos trabalhadores se submetem, em seus processos de produção, a agentes físicos, químicos, ou biológicos que podem ter "consequiências nefastas para sua saúde e sua capacidade de trabalho", sem falar do esgotamento e do estresse que geram.

Por conseguinte, a saúde dos trabalhadores está ameaçada nos mais diversos ramos de atividades, pois existe uma carência do acesso aos serviços de saúde do trabalho, e agravandose nos países em desenvolvimento e nos novos países industrializados, onde reside quase $80 \%$ da população trabalhadora mundial. Tem-se a considerar que a OMS indicou que os cânceres do pulmão, de bexiga, da pele e dos ossos são os "profissionalmente" mais comuns (SINDICATO DOS TRABALHADORES NAS INDÚSTRIAS METALÚRGICAS, MECÂNICAS E DE MATERIAIS ELÉTRICOS DE OSASCO E REGIÃO, 1996). 
Sabemos que as principais fontes de informações, acerca do acidente do trabalho são fornecidas, de um lado, pelas Comunicações de Acidentes do Trabalho (CAT), criada para fins securitários; de outro, pelos atestados de óbitos, porém a CAT só é obrigatória a informações sobre empregados regidos pela Consolidação das Leis do Trabalho (CLT) e segurados especiais. Um outro aspecto é que só prevê a concessão de um ano de estabilidade no emprego aos trabalhadores que recebem auxílio-doença acidentário, a contar do término do afastamento do trabalho. Este fato contribui para a subnotificação dos acidentes no Brasil; porém, apesar destas limitações, a CAT é utilizada para fins estatísticos e estudos epidemiológicos.

Binder e Almeida (2003 apud MENDES, 2003, p. 770-808) ${ }^{4}$ nos revelam que vários estudos realizados pela CAT demonstraram despreparo dos profissionais da Vigilância Sanitária, (Cortez, 2001); revelaram sub-registro, concluindo que a CAT é insuficiente como fonte de informação acerca do acidente do trabalho, (Rego, 1993); redução real dos acidentes pela introdução de novas tecnologias, processos de reestruturação produtiva, retração do setor secundário, concomitantemente à expansão do setor terciário da economia, (Ribeiro, 1994; e Wünsch Filho, 1999); verificação de que mais de dois terços dos acidentes estão ocorrendo fora dos espaços das empresas, mudança da realidade que precisa ser considerada e estudada com mais profundidade (Gawryszewski, Mantovani \& Lung, 1998); falta de qualidade de informação sobre a ocupação nas declarações de óbitos.

Marcellino (1999), ao estudar o sistema de informações sobre acidentes do trabalho em Ribeirão Preto, constatou que o referido sistema encontrava-se estruturado e organizado de modo incipiente, expressando-se na concretização de práticas profissionais, principalmente dos médicos do trabalho, da Delegacia Regional do Trabalho (DRT) e do Instituto Nacional de Seguridade Social (INSS), que eram intra e interinstitucionais desarticuladas, privilegiando prescrições legais e burocráticas. Um outro aspecto verificado é que esse modo de

\footnotetext{
4,5 BINDER, M. C P.; ALMEIDA, I. M. Acidentes do trabalho: acaso ou descaso? In: Mendes, René
} 
conformação do sistema de informação sobre acidentes do trabalho contribuía, para dificultar ações direcionadas à reversão do quadro de morbi-mortalidade da classe trabalhadora, característico da sociedade brasileira.

Binder e Almeida (2003 apud MENDES, 2003, p. 801) ${ }^{5}$ que:

Apesar dos esforços no sentido de superar a carência e a precariedade de dados na área Trabalho-Saúde, pode-se considerar que o Brasil chega ao século XXI com um importante problema de saúde pública, a elevada incidência de acidentes de trabalho, ainda mal dimensionado e mal caracterizado, o que dificulta enormemente o acompanhamento de sua evolução ao longo do tempo e, sobretudo, da avaliação do impacto dos numerosos fatores que sabidamente influem na ocorrência desses fenômenos.

Dados mais recentes do Ministério do Trabalho e Emprego (MTE) como podem ser vistos pelos gráficos abaixo (1, 2, 3 e 4) mostram uma diminuição dos acidentes de trabalho e de sua gravidade (BRASIL, 2001). Pensamos que as razões são as apontadas nos anos anteriores, ou seja, a subnotificação e a ausência de uma política pública integrada e efetiva na área saúde do trabalhador.

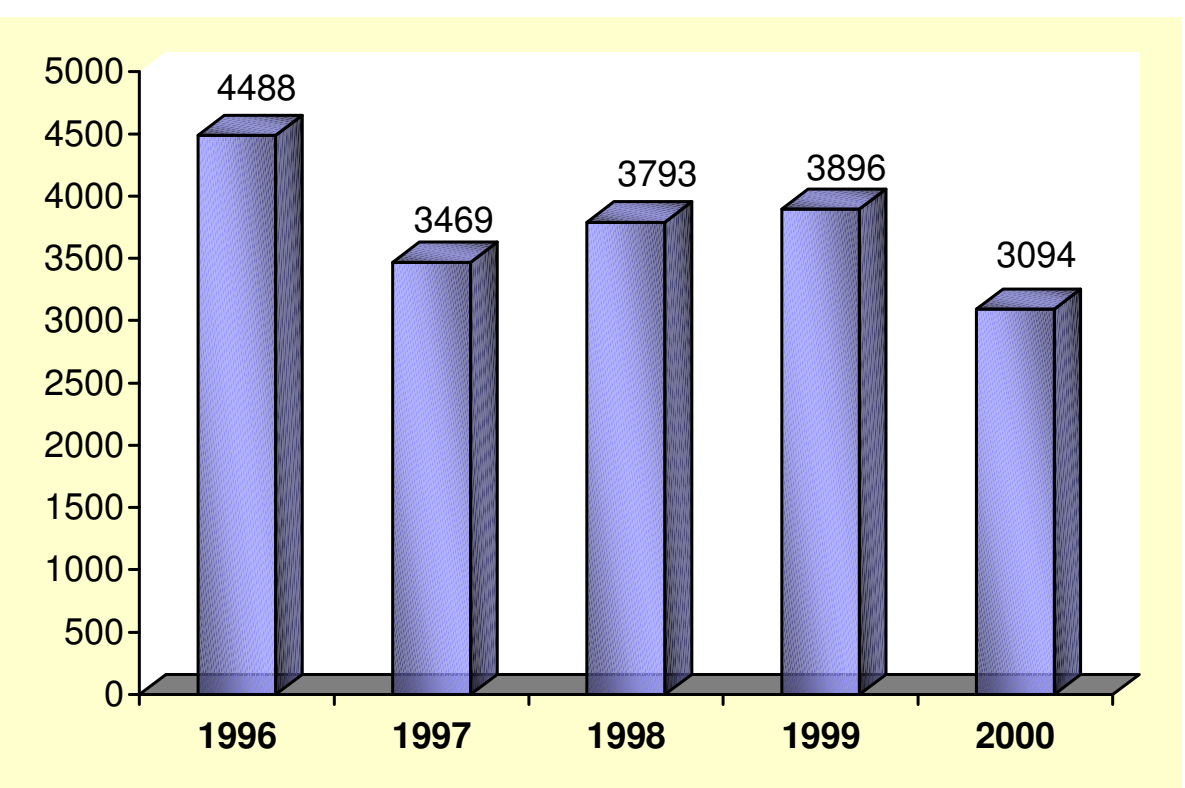

Fonte: Emprego - RAIS /MTE 
Acidentes de Trabalho - Anuário Estatístico / MPAS

Gráfico 1. Óbitos decorrentes do Acidente de Trabalho - 1996 a 2000

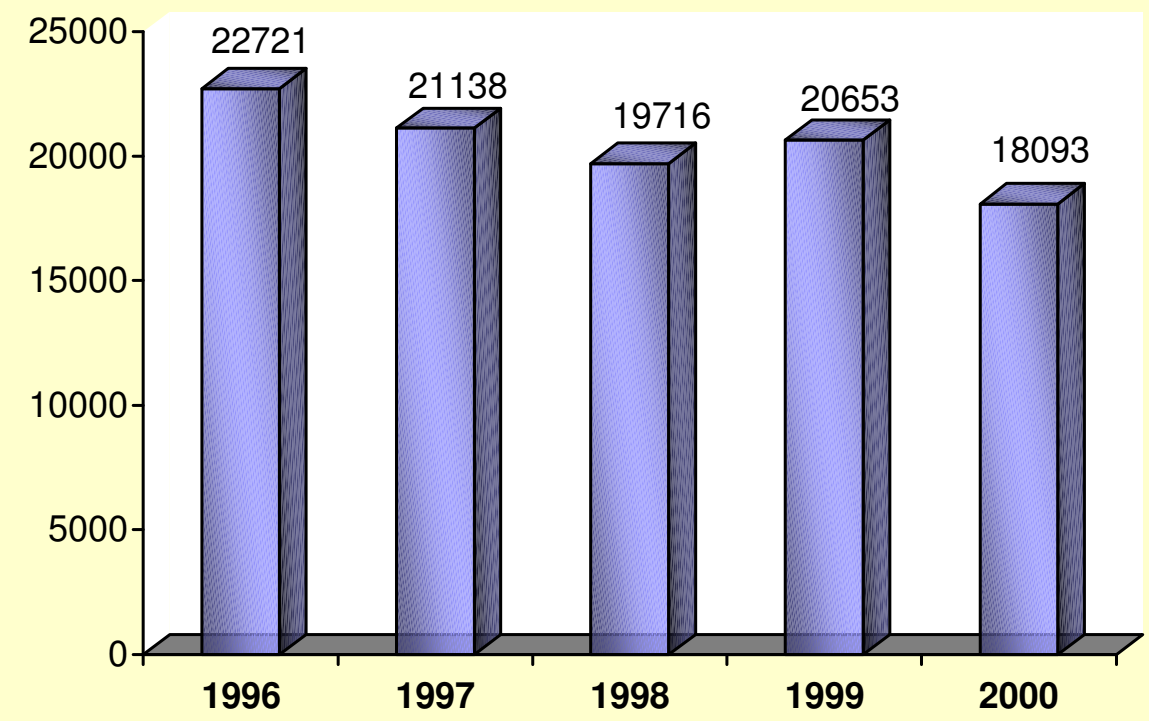

Fonte: Emprego - RAIS /MTE

Acidentes de Trabalho - Anuário Estatístico / MPAS

Gráfico 2. Acidentes de Trabalho Incapacitantes - 1996 a 2000

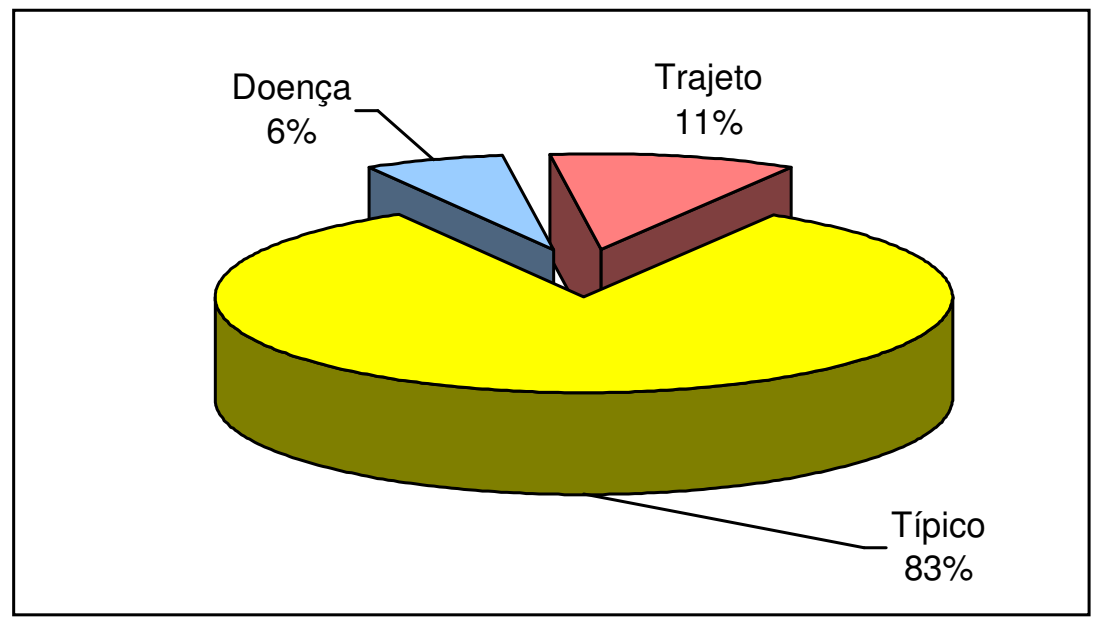

Fonte: Emprego - RAIS /MTE

Acidentes de Trabalho - Anuário Estatístico / MPAS

Gráfico 3. Distribuição de Acidentes do Trabalho Registrados - 2000 


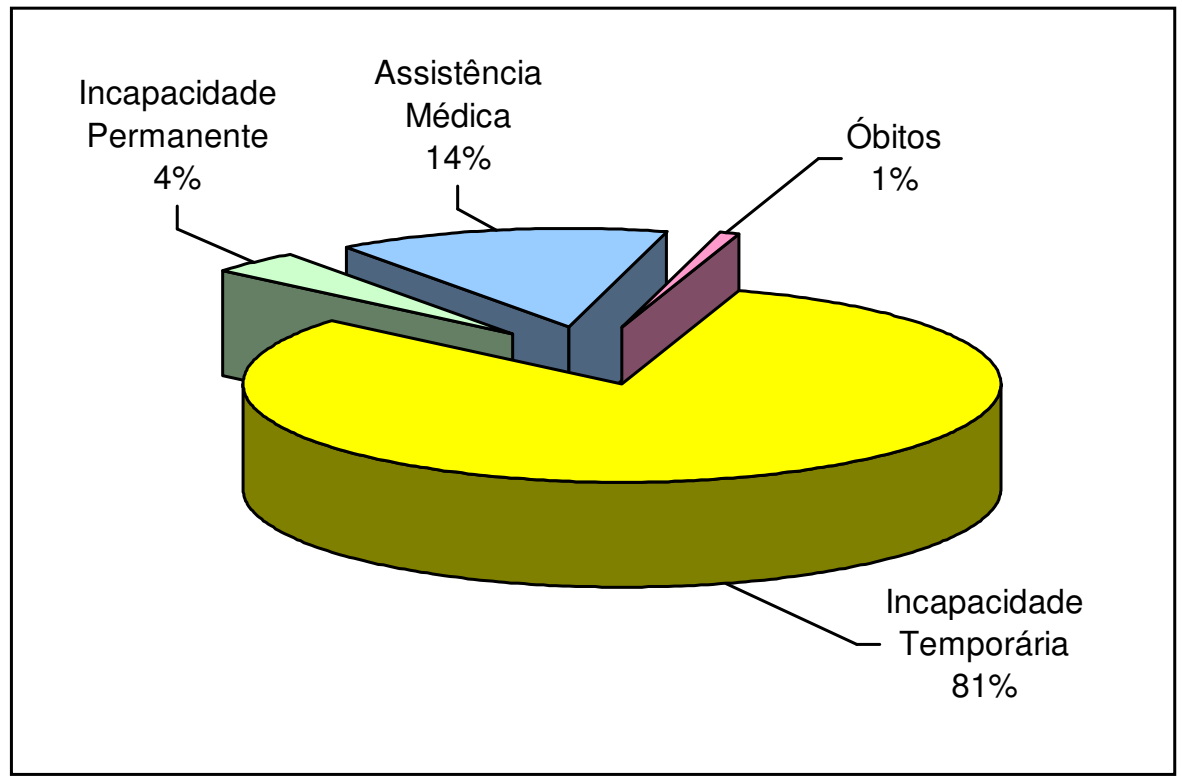

Fonte: Emprego - RAIS /MTE

Acidentes de Trabalho - Anuário Estatístico / MPAS

Gráfico 4. Distribuição de Acidentes de Trabalho Liquidados por conseqüência - 2000

Mais de 5.000 mortes e 25.025 incapacitados permanentes. Não constituem o saldo de uma guerra civil, mas o resultado de 428.072 acidentes de trabalho, ocorridos em 1996 no Brasil, gerando custos da ordem de R $\$ 4$ bilhões, conforme dados do Ministério do Trabalho e Previdência Social (BRASIL, 1999). E os números dos anos seguintes não são nada melhores, conforme apresentados anteriormente.

Tais dados apenas corroboram o que já foi dito até aqui, isto é, a realidade cotidiana do mundo do trabalho tem sido traduzida por acidentes, doenças e mortes no trabalho, sem que houvesse mudança significativa nos padrões estatísticos deles, por uma falta de articulação política na área, uma dispersão de ações; enfim, a ampliação da dimensão transformadora do trabalho.

Acreditamos que as considerações acerca da historicidade do processo de elaboração das políticas na área saúde do trabalhador e das articulações, que existem entre as esferas políticas-ideológias-econômicas e sociais apontam para importância do estudo da questão dos 
acidentes e doenças do trabalho no país, bem como para a necessidade do entendimento ampliado do processo saúde-doença, do trabalho como categoria central, para o entendimento de questões relativas ao nosso modo de vida, e, conseqüentemente, ao nosso modo de adoecer. Cabe agora explicitar o porquê da importância da CIPA no contexto educacional dentro da área de saúde do trabalhador.

\subsection{3 - A CIPA: constituição, legislação e atribuições}

A nossa experiência facilitadora, mais direta na área saúde e trabalho, apontou para a necessidade de estudar melhor o tema educação em saúde do trabalhador, como já mencionado anteriormente na escolha do objeto. Nosso entendimento foi de que os membros da CIPA seriam a instância central de multiplicação de conhecimentos e práticas, acrescentando-se o fato de eles lidarem com uma forma de organização que se propõe a discutir o acidente do trabalho, como também suas origens, medidas de prevenção e orientação, o que objetiva a diminuição do número de acidentes.

A Comissão Interna de Prevenção de Acidentes (CIPA), que foi instituída na criação da Consolidação das Leis do Trabalho (CLT) em 1945, porém não com essa denominação e atribuições, permaneceu adormecida nas gavetas até a criação do Serviço de Especializado em Segurança e Medicina do Trabalho (SESMT) em 1972, também não com esta denominação. Essa comissão sofre alteração em 1975, assim como em 1978, quando tomou impulso considerável. Em 1988 se fez presente na Constituição Federal. E desde então essa legislação, a NR-5, já sofreu várias alterações, dentre as quais, a de 1988 e a de 1999.

Mendes (1999), em sua análise sobre a CIPA em empresas públicas, chama a atenção para os ítens b, c, d, e, f, e j, da antiga redação da NR-5, que contemplam diretamente ações educativas, quais sejam: b) sugerir medidas de prevenção de acidentes julgadas necessárias, por iniciativa própria ou sugestões de outros empregados, encaminhando-as ao SESMT e ao 
empregador; c) promover a divulgação e zelar pela observância das normas de segurança e medicina do trabalho ou de regulamentos e instrumentos de serviços, pelo empregador; d) despertar o interesse dos empregados pela prevenção de acidentes e de doenças ocupacionais e estimulá-los permanentemente a adotar comportamento preventivo durante o trabalho; e) promover, anualmente, em conjunto com o SESMT, a Semana de Prevenção de Acidentes do trabalho - SIPAT; f) participar da campanha permanente de prevenção de acidentes promovida pela empresa e j) sugerir a realização de cursos, treinamentos e campanhas que julgar necessários, para melhorar o desempenho dos empregados, quanto à segurança e medicina do trabalho.

A respeito da sua criação, Zócchio (1980, p. 20) coloca que

Os primeiros serviços de segurança do trabalho foram organizados, há décadas e espontaneamente, por empresas mais interessadas no assunto, quase sempre em consequiência das atividades iniciadas pela CIPA-Comissão Interna de Prevenção de Acidentes. De início indecisos, sem planejamento, sem definição de responsabilidades, esses serviços adquiriram vícios e implantaram conceitos errôneos, que até hoje refletem negativamente na atuação e na aceitação dessa atividade no contexto administrativo de muitas empresas[...]Se a empresa e os dirigentes entenderem o que podem esperar e exigir e definirem uma política adequada para as atividades prevencionistas, terão garantido o êxito da prevenção de acidentes em toda a extensão e profundidade.

Assim ela, a CIPA, existente no país desde 1978, como obrigatoriedade legal nas empresas privadas, públicas e órgãos governamentais que possuem empregados regidos pela CLT, é constituída pelos empregados, que são eleitos anualmente de forma paritária, metade indicada pelo empregador e a outra metade eleita pelos empregados; isso é feito, conforme o número de funcionários e atividade da empresa.

As suas atuais atribuições são: 
a) identificar os riscos do processo de trabalho e elaborar o mapa de riscos, com a participação do maior número de trabalhadores, com assessoria do SESMT, onde houver;

b) elaborar um plano de trabalho que possibilite a ação preventiva na solução de problemas de segurança e saúde no trabalho;

c) participar da implementação e do controle da qualidade das medidas de prevenção necessárias, bem como da avaliação das prioridades de ação nos locais de trabalho;

d) realizar periodicamente, verificações nos ambientes e condições de trabalho, visando à identificação de situações que venham trazer riscos para a segurança e saúde dos trabalhadores;

e) realizar, a cada reunião, avaliação do cumprimento das metas fixadas, em seu plano de trabalho, e discutir as situações de risco que foram identificadas;

f) divulgar aos trabalhadores informações relativas à segurança e saúde no trabalho;

g) participar, com o SESMT, onde houver, das discussões promovidas pelo empregador, para avaliar os impactos de alterações no ambiente e processo de trabalho, relacionados à segurança e saúde dos trabalhadores;

h) requerer ao SESMT, quando houver, ou ao empregador, a paralisação de máquina ou setor, onde considere haver risco grave e iminente à segurança e saúde dos trabalhadores;

i) colaborar no desenvolvimento e implementação do PCMSO e do PPRA e de outros programas relacionados à segurança e saúde no trabalho;

j) divulgar e promover o cumprimento das Normas Regulamentadoras, bem como cláusulas de acordos e convenções coletivas de trabalho, relativas à segurança e saúde no trabalho; 
1) participar, em conjunto com o SESMT, onde houver, ou com o empregador, da análise das causas das doenças e acidentes de trabalho e propor medidas de solução dos problemas identificados;

m) requisitar ao empregador e analisar as informações sobre questões que tenham interferido na segurança e saúde dos trabalhadores;

n) requisitar à empresa cópias das CAT emitidas;

o) promover, anualmente, em conjunto com o SESMT, onde houver, a Semana Interna de Prevenção de Acidentes do Trabalho - SIPAT;

p) participar, anualmente, em conjunto com a empresa, de campanhas de prevenção da AIDS.

Destacamos os itens b), c), f), g), i), j), m), o) e p), por estarem mais diretamente relacionados à educação nos ambientes de trabalho.

Mendes (1999) coloca que o treinamento exigido para os "cipeiros" (20 horas) segue um currículo único em qualquer caso, quando deveria ser direcionado aos riscos específicos das empresas. Acrescenta a autora que o conteúdo não é suficiente à capacitação os membros da CIPA, para a devida orientação dos trabalhadores, em virtude da variedade das situações de risco que podem ocorrer nos ambientes de trabalho. Reiteramos o seu pensamento e ainda colocamos; se não houver a habilitação suficiente e necessária ao caso, a orientação, bem como a multiplicação do conhecimento, ficarão muito prejudicadas.

Pode-se notar que existe, ainda, a dificuldade de uma política de atuação, dentro das organizações para a CIPA, apesar de o texto da NR-5 fornecer o caminho a ser seguido; em relação às suas atribuições, vemos que isso nem sempre está claro para as empresas, nem mesmo para os "cipeiros". Isso não ocorre em relação à sua organização, pois o texto não alterou o fato de a indicação do Presidente da CIPA ser realizada pelo empregador. É relevante o fato de que, geralmente, a CIPA por estar ligada a alguma estrutura estanque 
dentro das empresas, acaba não cumprindo seu papel de prevenção de acidentes na sua totalidade.

Outro problema é o de carência de programas adequados e definidos para prevenção de acidentes, que, de certa forma, generaliza-se. Ainda não são muitas as empresas que possuem programas de segurança, definidos e consolidados em diretrizes sólidas, ponto fundamental para a prevenção de acidentes do trabalho. Zócchio (1980, p. 28) prevê um modelo de organização onde a CIPA aja como um mecanismo que deveria estar vinculado a todos os setores da empresa,

Como nos esquemas convencionais de organização, também na segurança do trabalho cada nível técnico ou administrativo responde ao seu imediatamente superior, de quem recebe incumbências e instruções específicas. O serviço de segurança do trabalho, no entanto, coloca-se como um setor vertical, pois tem necessariamente de manter contatos e de assistir a todos os níveis na matéria. A CIPA, que em muitos casos pode - e onde não há serviço de segurança deve - manter semelhantes contatos, não pode comportar-se como um setor vertical, por não ser um órgão do organograma da empresa, mas tão somente uma comissão mista imposta por lei.

Concordamos com este pensamento, pois a CIPA, por ser um órgão legitimado por lei e que, pressupõe a participação dos trabalhadores para o seu funcionamento, só tem sentido, se trabalhar nessa direção, a de assegurar que toda a empresa esteja envolvida com a questão da prevenção dos acidentes, por meio de práticas educativas.

Porém, em que pese toda essa realidade, entendemos que a CIPA, por ser uma instância legal dentro das empresas, aliás, o único tipo de organização no local de trabalho legalmente reconhecido, pode prestar grande serviço aos trabalhadores em geral. Em decorrência de sua atribuição, pode convocar os trabalhadores, para discutir os acidentes do trabalho ocorridos, bem como, investigar ou participar, com o SESMT, da investigação de causas, circunstâncias e conseqüências dos acidentes e das doenças ocupacionais. Ainda pode acompanhar a 
execução das medidas corretivas, organizar a SIPAT e confeccionar o mapa de risco. Então, se os "cipeiros" souberem aproveitar este espaço real, conferido à CIPA, poderão se beneficiar de uma ação mais efetiva de prevenção dos acidentes.

Ora, se as empresas são obrigadas a terem CIPA, ela deveria cumprir o seu papel de revelar os acidentes ocorridos. Neste caso, esperaríamos que ela, a CIPA cumprisse o seu papel de desvendar ao trabalhador as condições de trabalho a que são submetidos. Porém, isto nem sempre ocorre, como pode ser visualizado pelo gráfico (5). Dados recentes do Ministério do Trabalho e Emprego (BRASIL, 2002), por meio das fiscalizações das DRT's, mostram que 5,9\% dos acidentes ocorrem por falha na antecipação, 5,9\% ocorrem por modo operatório inadequado, 3,97\% por falta ou inadequação da análise da tarefa; em síntese, culpabilização do trabalhador aliado à falta de atividade educacional.

Evidencia-se, mais uma vez, a importância do treinamento adequado, como também a necessidade, em termos de contribuição à produção de conhecimento, de analisar, sob uma perspectiva mais ampla, a questão da educação em saúde no contexto da saúde do trabalhador, exercida pela da CIPA e pelas SIPAT's promovidas por ela. 


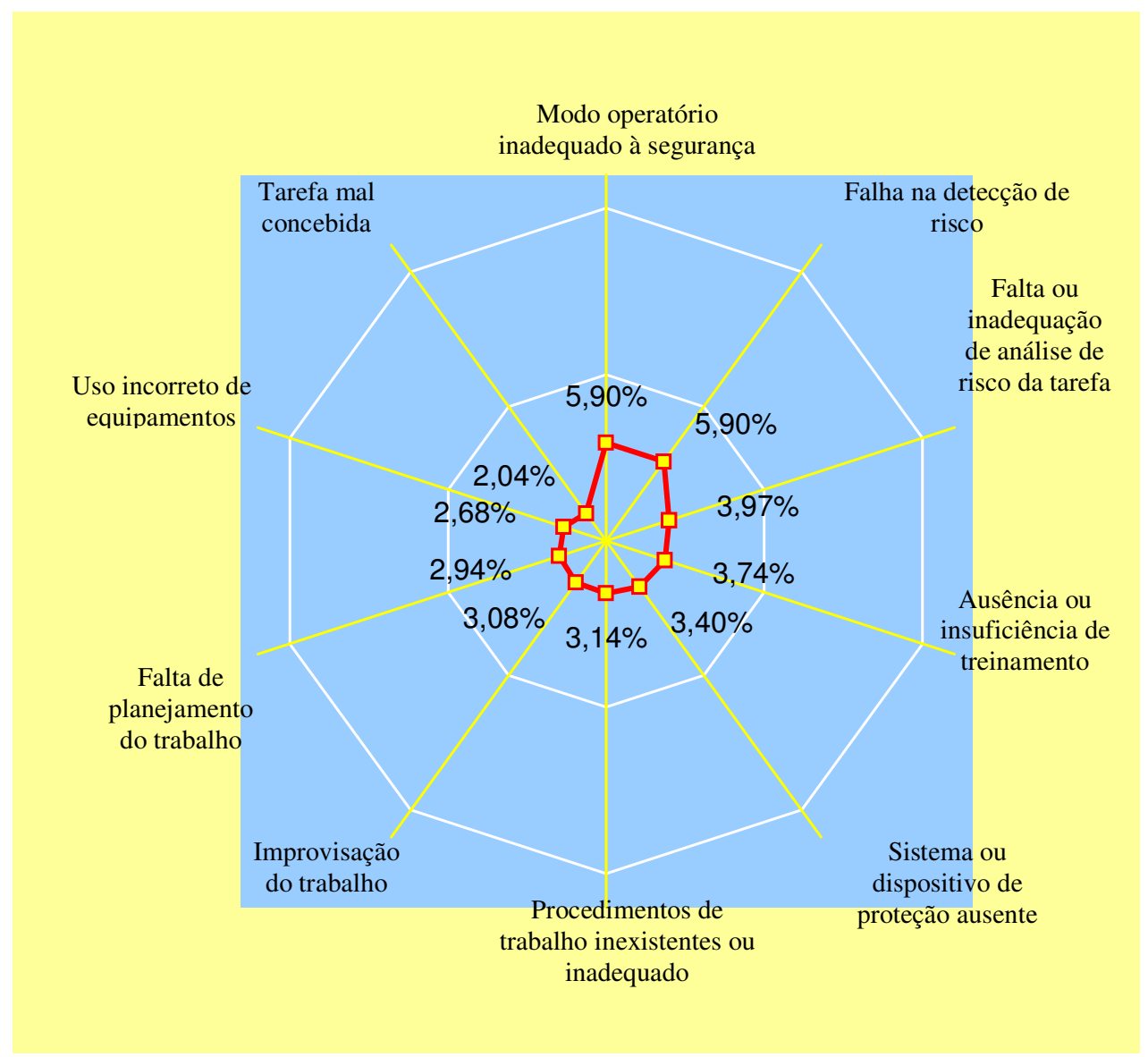

Fonte: Sistema Federal de Inspecção do Trabalho/Acidentes Analisados/ Brasil. Gráfico 5. Principais Fatores Causais dos Acidentes de Trabalho Analisados Janeiro a Dezembro de 2002

\section{3 - A educação}

\subsection{1 - O modelo de Paulo Freire: as bases teóricas da educação conscientizadora}

Ao tentarmos pensar na categoria educação, não poderíamos deixar de falar sobre Paulo Freire, pois ele foi um dos primeiros educadores a romper com os modelos, paradigmas e teorias tradicionais, elaborando um pensamento pedagógico novo, ousado, crítico e radical (GADOTTI, 1991).

Gadotti (1996) revela que não se poderia falar em "Método Paulo Freire", pois se trata muito mais de uma teoria do conhecimento e de uma filosofia da educação do que de um 
método de ensino. Já Freire (1996) ressalta a abrangência e a longevidade das idéias de Paulo Freire, discorrendo sobre sua vasta experiência em educação popular. Segundo a autora, as idéias concebidas pelo autor representam a essência e o retrato do próprio educador Paulo Freire, (FREIRE, 1996, p. 63),

É desse modo que no seu que-fazer e nas suas reflexões, carrega as suas experiências pessoais, molhadas, como gosta de dizer, das influências deste mundo que é ao mesmo tempo seu e não o é. É da relação dele com o mundo que inclui o outro. Assim, reinventado e superando, em parte ou no todo, muitos dos mestres, foi - e continua construindo a sua própria maneira de pensar. Não há como negar a sua maneira própria de pensar, porque reinventa e supera em parte ou no todo muitos dos seus mestres, a influência do marxismo, do existencialismo, do personalismo ou da fenomenologia. São presenças na sua leitura de mundo tanto Marx, Lukacs, Sartre e Mounier quanto Albert Memmi, Erich Fromm, Frantz Fanon, Merleau-Ponty, Antonio Gramsci, Karel Kosik, Marcuse, Agnes Heller, Simone Weill e Amílcar Cabral.

Gadotti (1996, p. 107), ao realizar em parceria uma biografia sobre Paulo Freire nos

revela que

Três filosofias marcaram a obra e vida de Paulo Freire: o existencialismo, a fenomenologia e o marxismo, como aponta Carlos Alberto Torres em seu livro estudos freireanos. Como a de Hegel e a de Marx, Paulo Freire faz a crítica da religião e da teologia, a crítica da filosofia e da alienação política, social e econômica. Sucessivamente - quase em fases diferentes - Paulo analisa as consequiências sociais, políticas e pedagógicas das diversas formas de relação entre os seres humanos. Paulo freire nos fala em "oprimidoopressor" (anos 50-60), em opressão "de classe" (anos 60-70) e opressão de "gênero e raça" (anos 80-90)."

Paulo Freire expressou de muitas formas suas idéias sobre Educação. Defendeu a forma crítica de ensinar do professor, em detrimento da simples transferência de conhecimento, e a forma crítica de aprender, lendo e compreendendo o mundo (FREIRE, 1987). Freire (1994), traçou sua trajetória de educador como sujeito comprometido com a história, analisando fatos de sua infância até os atuais, como democracia e corrupção, sem 
esquecer-se da aproximação crítica e da prática do diálogo. Freire (1996) mostrou como o professor libertador educa para a mudança social e explorando a questão da libertação e da diferença de linguagem entre educadores e alunos, inclusive nos Estados Unidos da América. Também fez uma releitura de sua "pedagogia do oprimido", dos fatos marcantes na sua luta pela alfabetização, nos vários países em que trabalhou, transformando-a na "pedagogia da esperança" (FREIRE, 1997).

Anterior a Freire, destaca-se o filósofo Álvaro Vieira Pinto, como um dos professores do Instituto Superior de Estudos Brasileiros (ISEB). Foi um dos primeiros a conceber os conceitos relacionados à natureza da consciência, para definir novas modalidades de pensamento, em contraste com as antigas representações da realidade nacional da época. Desde então, Paulo Freire integrou esses conceitos ao seu vocabulário, reelaborando-os.

Descrevemos aqui, um primeiro aspecto de sua teoria, reconceituado por Freire (1997), de consciência intransitiva, que resulta de um estreitamento no poder de captação da consciência, na qual o homem não enxerga e não ouve os desafios que estão além da esfera vegetativa. Como a intransitividade produz uma consciência mágica, as causas atribuídas aos desafios escapam à critica e tornam-se superstições. O segundo, consciência transitiva, que, no primeiro momento, é ingênua caracterizando-se por um simplismo na interpretação dos problemas, por meio de conclusões apressadas e superficiais. Isso leva a argumentações frágeis e polêmicas, bem como a compreensões mágicas, e entendendo-se a realidade como estática. O terceiro, o da consciência crítica, substitui explicações mágicas por causas verdadeiras e analisa os problemas em profundidade. É inquieta, indagadora, dialógica e reconhece que a realidade é mutável (FREIRE, 1997).

Sendo o homem um ser de relações, aberto à realidade, é possível que ele conheça o mundo e responda a uma variedade de desafios. No ato de responder, há uma pluralidade de respostas que se traduzem em organizar-se, agir, discernir sobre sua existência, finitude, 
temporalidade e historicidade. Quando discerne, incorpora, vai dominando e modificando a realidade (FREIRE, 1996).

A conscientização, para Freire, está baseada na relação consciência - mundo (FREIRE, 1980). Quando numa sociedade há uma mudança econômica, a consciência pode se promover transitivamente, de maneira automática. Em relação à consciência crítica, a mudança somente se dá por um processo educativo de conscientização (FREIRE, 1997).

A pedagogia conscientizadora de Paulo Freire leva, em consideração, vários aspectos, dentre eles: a indissociabilidade entre o homem e o mundo, pois o homem é o sujeito da educação; apesar de uma ênfase no sujeito, evidencia-se uma tendência interacionista, já que a interação homem-mundo, sujeito-objeto é imprescindível, para que o ser humano se desenvolva e torne-se sujeito de sua práxis. Sendo o homem sujeito de sua própria educação, toda ação educativa deverá promover o próprio indivíduo, não como instrumento de ajuste à sociedade. Assim, o homem é um ser que possui raízes espaço-temporais: é um ser situado no e como mundo. É um ser da práxis, compreendida por Freire como ação e reflexão dos homens sobre o mundo, com o objetivo de transformá-lo.

Mendes (1993) relembra a ênfase de Paulo Freire ao fato que, o homem, por sua temporalidade e historicidade, acaba sendo ativo e eminentemente interferidor em sua realidade, tornando-se capaz de modificá-la, conforme já mencionamos. Outra idéia de Paulo Freire é a substituição da escola, autoritária por estrutura e tradição, pelo círculo de cultura, como peça fundamental do movimento de educação popular que busca reunir homens do povo; no trabalho comum pela conquista da linguagem escrita, aparece a figura do "educador", membro participante do círculo, facilitador da aprendizagem e da participação dos educandos, aberto à crítica.

Gadotti (1991) nos revela que, na concepção de Paulo Freire, o diálogo é uma relação horizontal que se nutre de amor, humildade, esperança, fé e confiança, fundamento da 
educação problematizadora; na relação dialógico-dialética, entre o educador e o educando, ambos aprendem juntos. O diálogo é, portanto, uma exigência existencial que possibilita a comunicação e permite ultrapassar o imediatamente vivido. Ao ultrapassar as suassituações limites, o educando chega a uma visão totalizante do contexto. O autor mencionadonos diz ainda: Paulo Freire entende que é possível engajar a educação num processo de conscientização e de movimento de massas, quando apresenta no seu livro "Educação como prática da liberdade", o conceito de consciência transitiva crítica, entendendo-a como a consciência articulada com a práxis; para chegar-se a essa consciência, que é, ao mesmo tempo desafiadora e transformadora, são imprescindíveis o diálogo crítico, a fala e a convivência (GADOTTI, 1997). Freire (1980, p. 57) afirma: “Os oprimidos não obterão a liberdade por acaso, senão procurando-a em sua práxis e reconhecendo nela que é necessário lutar para consegui-la".

Gomes (2001) nos revela que o trabalho de Freire, não somente por causa do seu refinamento teórico, mas por causa do sucesso de Freire em colocar a teoria na prática, tem sido relembrado por educadores em todo mundo e constitui uma importante contribuição para a pedagogia crítica.

É importante ressaltar que, ao nosso ver, diferente da informação, a educação é um processo contínuo, de interação entre sujeitos articulados com o sócio-cultural. Ao contrário, a informação é pontual, nem sempre interativa; desse modo, descreve o real pela associação associada a um referencial explicativo, ou pela ligação entre as idéias de algumas pessoas ás idéias ou representações de outras.

MacLaren (1997, p. 329) comenta que

Através da união de história, política e economia aos conceitos de cultura e poder, Freire desenvolveu uma linguagem crítica e uma linguagem de esperança que, juntas, provaram ser eficazes na libertação das vidas de gerações excluídas”, considerando que, para 
ele, "os seres humanos não flutuam sem objetivo em um mar de abstrações; eles estão firmemente enraizados na batalha histórica e nunca perdem sua capacidade de sofrer ou sua vontade de mudar o mundo.

De fato, suas estruturas pedagógicas são planejadas para a libertação, oferecendo possibilidades individuais e coletivas para "reflexão e ação". (MACLAREN, 1997, p. 330) Para ele, "a comunicação dialógica deve instigar educadores a deterem-se no capital cultural do oprimido, para que este tenha oportunidade de ler o mundo em contextos amplos e imediatos".

Nota-se que o modelo Paulo Freire é libertador, dialético e social, ao gerar consciência voltada a uma autonomia e para a transformação das práticas vigentes, sejam elas os próprios processos educacionais, as lógicas institucionais, o ambiente de trabalho e, conseqüentemente, o próprio cotidiano.

Há uma década, 1989, com base nas idéias de Paulo Freire, alguns educadores anunciaram as bases de uma prática pedagógica contrária à pedagogia tradicional. Pouco depois, nessa linha, alguns educadores brasileiros se pronunciaram em favor dessas "concepções atuais de educação" da época, numa direção político-pedagógica mais autônoma que a vigente (GADOTTI, 1991). Esse novo pensamento pedagógico, que, era de orientação "crítica" e "progressista", foi ganhando espaço nas universidades; entretanto, na prática encontrou muita resistência pelo "conservadorismo" histórico vigente no país (GADOTTI, 1991).

Gadotti (1997) apresentou sua concepção dialética da educação, em que fez uma crítica à educação burguesa, à luz do pensamento marxista. Dentre outros temas, fez considerações sobre a integração dos conceitos de educação e formação profissional, isto é, ensino e trabalho integrados, como forma de o homem sair da alienação e reunificar-se com a sociedade, fora da divisão social do trabalho. 
Brandão (2003, p. 73), ao analisar o que é a educação, afirma que ela é antes de tudo um ato social

[...] a educação é uma prática social (como a saúde pública, a comunicação social, o serviço militar) cujo fim é o desenvolvimento do que na pessoa humana pode ser aprendido entre os tipos de saber existentes em uma cultura, para a formação de tipos de sujeitos, de acordo com as necessidades e exigências de sua sociedade, em um momento da história de seu próprio desenvolvimento.

Esse autor também afirma que: "Como outras práticas sociais constitutivas, a educação atua sobre a vida e o crescimento da sociedade em dois sentidos: 1) no desenvolvimento de suas forças produtivas; 2) no desenvolvimento de seus valores culturais” (BRANDÃO, 2003, p. 75).

A educação não deve ser pensada como único meio de transformação da realidade, mas em conjunto com outras práticas, como "arma" poderosa de mudanças. Deve estar associada ao desenvolvimento social, político e cultural de uma sociedade, sabendo que é na práxis que o processo de aprendizagem ocorre; por um lado, com uma dimensão subjetiva, conjunto de conhecimentos e relações que buscam explicações para os fenômenos, e, por outra, dimensão objetiva, mobilização e articulação dos conhecimentos e valores para o enfrentamento das situações concretas (BRANDÃO, 2003).

Segundo Bordenave $(1982,1987)$, todos os processos educativos, assim como as técnicas educativas que são instrumentos de ensino-aprendizagem, se baseiam em uma determinada concepção de "como conseguir que as pessoas aprendam e modifiquem sua prática”. No caso concreto do presente trabalho, como conseguir que as pessoas tenham uma melhor saúde. Essas concepções, por sua vez, fundamentam-se em um determinado modelo ou ponto de vista do que seja educar. Entre esses, podem-se considerar: o modelo tradicional que enfatiza os conteúdos temáticos, o modelo condutor com ênfase nos efeitos e o modelo participativo, que enfatiza o processo. 
Este último, denominado por Freire $(1979,1989$ a) de educação conscientizadora, problematizadora, ou libertadora, parte do princípio de que, num mundo em transformação, sedimentado por mudanças rápidas e profundas, o importante não são os conhecimentos ou idéias, nem os comportamentos adequados, conforme às expectativas, senão o aumento da capacidade das pessoas/grupos, para detectar os problemas reais, buscando-lhes solução original e criativa. A experiência que deve ser valorizada é a observação grupal da própria realidade, o diálogo e a participação na ação transformadora das condições de vida. O conhecimento é socializado e desmistificado, a cultura, não: é reflexa, mas criativa e autônoma. Nessa opção, o grupo é visto como sujeito e a relação de diálogo, uma relação de iguais.

Diante disso, o educar é entendido, mais uma vez, como um ato de reciprocidade, onde o saber é construído constantemente, entre as partes envolvidas no processo, conforme afirma Brandão (1982).

Ao pensar no processo do "educar", concordamos com Freire (1979, p. 6-7), ao sintetizar o compromisso histórico do homem na produção desse saber:

a primeira condição para que se possa assumir um ato comprometido está em ser capaz de agir e refletir. [...] Somente um ser que é capaz de sair do contexto, de distanciar-se dele para ficar com ele, capaz de admirá-lo para, objetivando-o, transformá-lo e, transformando-o saber-se transformado pela sua própria criação; um ser que é e está sendo no tempo que é seu, um ser histórico.

Assim, entendemos que educar é um ato dialético e de reciprocidade entre quem ensina e quem aprende, ou seja, não existe a dicotomia entre a teoria e a prática; logo, o saber é construído constantemente, entre as partes envolvidas no processo, pressupondo um planejamento com vistas a uma ação. 


\subsection{2 - A educação em saúde}

Trabalhos de Teodoro (1997); Mendes (1999); Nakatani (2000) mostram que a educação em saúde, como prática cotidiana, pode contribuir para a conscientização e, conseqüentemente, para a melhoria da saúde de uma dada população, aqui entendida como qualidade de vida.

Para Green e Kreuter (1991 apud CANDEIAS, 1997, p. 2) ${ }^{6}$, entende-se por educação em saúde quaisquer combinações de experiências de aprendizagem delineadas, com o intuito de facilitar ações voluntárias, conducentes à saúde. A palavra "combinação" enfatiza a importância de integrar múltiplos determinantes do comportamento humano a múltiplas experiências de aprendizagem e de intervenções educativas. A palavra "delineada" distingue o processo de educação em saúde, de quaisquer outros processos que contenham experiências acidentais de aprendizagem, apresentando-o como uma atividade sistematicamente planejada. "Facilitar" significa predispor, possibilitar e reforçar. "Voluntariedade" significa sem coerção, com plena compreensão e aceitação dos objetivos educativos implícitos e explícitos nas ações desenvolvidas e recomendadas. "Ação" diz respeito a medidas comportamentais, adotadas por uma pessoa, grupo ou comunidade, para alcançar um efeito intencional sobre a própria saúde.

Para Schall (1999), uma educação em saúde ampliada inclui políticas públicas, ambientes apropriados e a reorientação dos serviços de saúde, para além dos tratamentos clínicos e curativos, assim como propostas pedagógicas libertadoras, comprometidas com o desenvolvimento da solidariedade e da cidadania.

Numa perspectiva pedagógica tradicional, os problemas educacionais são os da transmissão das informações. Ao contrário, propomos aqui, a utilização do embasamento da teoria da problematização, aplicada ao processo de trabalho. Entendemos que as atividades de educação em saúde deveriam se dar numa perspectiva crítico-reflexiva, incentivando os

\footnotetext{
${ }^{6}$ GREEN, L.W. e KREUTER, M.W. Health promotion planning, an educational and

environmental approach. 2 ed. Mountain View: 1991.
} 
trabalhadores a buscarem alternativas para mudanças; para isso, é importante que eles assumam o papel de sujeitos ativos, numa verdadeira prática social de educação, mobilizadora de várias possibilidades e saberes.

Ao salientarmos esses conceitos, nós o fazemos, ainda, em relação à necessidade de as práticas estarem, vinculadas à constante revisão. Isso deve acontecer não somente do ponto de vista técnico, mas também, em relação à ação interativa dos sujeitos envolvidos no processo, uma ação que contemple aspectos sócio-culturais.

Não existindo uma receita pronta e acabada para o desenvolvimento de uma atividade educativa com a população, quer um trabalho individual ou grupal, o mais importante é a postura do profissional de saúde frente à população. Ele é, aqui, entendido como todo aquele que, de uma forma ou de outra, lida com o paciente, com o doente, mas também aquele que trabalha no sentido de reduzir os agravos, ou seja, os determinantes causadores das doenças. Nesse aspecto, enquadram-se, o médico, o dentista, o enfermeiro, o fisioterapeuta, o psicólogo, o fonoaudiólogo, o nutricionista, o farmacêutico, o auxiliar e o técnico de enfermagem, mas também o pedagogo, o sociólogo e o assistente social, entre outros, desde que estejam conscientes e comprometidos com a questão da saúde individual e/ou coletiva.

Cocco (1999), ao refletir sobre as práticas educativas em saúde que os profissionais têm vivenciado em seu cotidiano, buscou sensibilizá-los, a fim de que atuem voltados para uma relação democrática, na construção da autonomia e cidadania dos usuários dos serviços de saúde. Ela afirma que as práticas educativas em saúde têm estado presentes no cotidiano dos profissionais de saúde e dos usuários dos serviços de saúde; porém, não conseguem, de modo geral, gerar grandes transformações que tenham impacto no comportamento da população, em suas condições de saúde e na construção de sua cidadania. Especificamente, no que se refere às práticas educativas em saúde, 
A clientela que compõe os grupos poderia ser organizada como coparticipante dos resultados de determinação social sobre sua saúde. Não é uma soma aleatória de indivíduos, são sujeitos, agentes de uma prática, que se conscientizam à medida que rompem as barreiras da alienação e que têm elementos de decisão, que permitem uma interação a caminho da transformação crítica da sociedade (COCCO, 1991, p. 96).

Concordamos com os teóricos críticos da educação em relação ao conhecimento, como uma construção social, profundamente enraizada em um nexo de relações de poder. Contudo, não é incomum a associação entre educação e treinamento, entre saúde e produtividade, de forma linear, simétrica, como se estas manifestações fossem excludentes da relação entre educação, saúde e poder. Ensinar e aprender não são categorias excludentes, mas, intrínsecas. O conhecimento tem sido a pedra fundamental neste processo de apropriação do mundo pelos sujeitos, com graduações diversas, em diferentes períodos históricos do processo de desenvolvimento da sociedade.

Esse conhecimento pode ocorrer de diversas formas; assim, ao discutir a pedagogia crítica, Maclaren (1997) retoma as formas de conhecimento, trabalhadas por Habermas que são: o conhecimento técnico, o conhecimento prático e o conhecimento emancipatório, que concordamos serem fundamentais numa perspectiva crítica de construção do homem. Assim, nos revela (MacLaren, 1997, p. 4):

O conhecimento emancipatório nos ajuda a entender como os relacionamentos sociais são distorcidos e manipulados por relações de poder e privilégio...Almeja criar as condições, sob as quais a irracionalidade, a dominação e a opressão podem ser superadas e transformadas através da ação reflexiva coletiva [...] Cria as bases para justiça social, igualdade e distribuição de poder.

Não existe neutralidade na interação entre as pessoas e a vida cotidiana. As possibilidades, em relação aos interesses presentes na realização de atividades educativas, 
junto da população são inúmeras. Já as atividades que propiciem um "conhecimento emancipatório”, fazendo sentido em seu cotidiano, são em menor número.

Cocco (1991) afirma que a ideologia que perpassa as práticas educativas é a possibilidade de os indivíduos tornarem-se autônomos e exercerem seus direitos como cidadãos. A apropriação do conhecimento não é fragmentada, dá-se continuamente, num processo de acumulação, no qual ocorrem avanços e rupturas. Quando as pessoas repensam, por exemplo, a incorporação de atividades físicas e de lazer em seu cotidiano, necessitam repensar sua vida, seus valores, sua intencionalidade em relação ao futuro.

A autora nos lembra que temos encontrado, muitas vezes, na prática profissional, a visão do processo de educação em saúde como algo compartimentalizado, visto freqüentemente, sob a ótica da instituição e/ou do profissional de saúde. Nesse percurso, a clientela participa das práticas educativas, segundo a perspectiva de um determinado tipo de troca, que não é uma troca responsável por saberes e interesses, entre os profissionais e a clientela. No entanto, participação dessa clientela em troca de medicamentos e/ou um atendimento "diferenciado" por parte dos profissionais vinculados ao grupo (COCCO,1991).

Todas as reflexões trazidas por essa autora nos remetem à importância de repensar a educação como geradora de consciência, para que se respeite o processo sócio-histórico dos envolvidos. Isso traz à tona a questão ideológica da educação e a necessidade da sistematização e da transdisciplinaridade da educação em saúde, como área do conhecimento e técnica de abordagem, com a finalidade de melhoria das condições de saúde e de trabalho de uma forma ampla.

Ceccim e Armani (2001) ao estudarem a educação em saúde coletiva como uma área especializada do conhecimento, colocam que, na saúde coletiva, a educação abrange o processo de formação especializada de profissionais, a qualificação para a percepção 
ampliada da saúde e a resposta segura dos sistemas e serviços de saúde às demandas coletivas da população.

Assim, Ceccim e Armani (2001: 32) afirmam que:

[...] à educação em saúde pública corresponde tanto o processo de formação para a reforma sanitária em curso no Brasil como a qualificação em processos de planejamento, gestão e avaliação de sistemas e serviços de saúde. À educação em saúde pública compete o protagonismo político-pedagógico de implantação do Sistema Único de Saúde (SUS), isto é, o processo de formação para a reforma sanitária, em curso no Brasil, desde a sua legislação recente (Constituição Nacional e Lei Orgânica da Saúde).

Os autores afirmam, ainda, que entendem o ofício da educação em saúde coletiva como o de verter em docência, pesquisa, cooperação técnico-científica e articulação ensinoserviço-controle social, de todos os aspectos de interesse ou relevância social que contribuam à elevação da qualidade de saúde da população, tanto nos aspectos epidemiológicos e demográficos, quanto nos aspectos de organização da gestão e estruturação do cuidado à saúde. Diferentemente de uma estratégia de capacitação para a condução política do sistema de saúde, a educação em saúde coletiva passa a pertencer à estratégia de condução política do sistema de saúde que amplia a inteligência coletiva da gestão sanitária.

Ceccim e Armani (2001) concluem que a lei que inaugura e dá legitimidade à atual reforma sanitária, em todo o território nacional não assegura um projeto contínuo atual; entretanto, deve ser pensado problematicamente, pois constitui a natureza do fazer educacional.

Se observarmos o contexto em que se insere a educação em saúde no SUS, na área da saúde coletiva, bem como a prática concreta dos profissionais que atuam diretamente com os usuários, podemos dizer que essa prática deveria alcançar uma outra forma de apreensão do 
fenômeno educativo, como processo de construção da existência individual e coletiva, num determinado contexto histórico e social.

\subsection{3 - A educação em saúde no contexto da saúde do trabalhador: concepções e}

\section{historicidade}

Ao procurarmos encontrar uma definição sobre educação em saúde nos ambientes de trabalho, objeto de estudo de várias áreas do conhecimento, como a sociologia, economia, antropologia e educação, estabelecendo diversas inter-relações, em diferentes campos do

conhecimento, deparamo-nos com aspectos importantes; entre eles o contexto histórico, social, ideológico e econômico em que essa prática surgiu, como coloca Gadotti (1997).

Pezzato e Cocco (2001), analisando o tema educação e trabalho, nas décadas de 1960 e 1990, e sua contextualização na área da saúde, afirmam que o tema passou portrês diferentes momentos em seu movimento teórico no Brasil: nos anos 1960, observou-se uma relação entre educação e trabalho tratada na perspectiva do desenvolvimento econômico e social. Nesse particular, a educação é tomada, como instrumento capaz de promover o desenvolvimento econômico pela qualificação da força de trabalho. Da década de 1970 até meados da década de 1980 , a relação entre educação e trabalho é tratada no âmbito das relações, entre educação e desenvolvimento, entre educação e sociedade. Tomavam o trabalho como princípio educativo, o que envolvia a pedagogia do trabalho e, ainda, a proposta da educação politécnica. Finalmente, na década de 90, constatou-se como desafio para os pesquisadores, a busca de articulação entre os aportes teóricos e metodológicos nas diferentes áreas da produção do conhecimento, sinalizando o trabalho interdisciplinar.

(PEZZATO; COCCO, 2001, p.32) afirmam que 
Na pedagogia do trabalho, os estudiosos buscaram explicar o papel da 'educação formal' na preparação para o trabalho, destacando que o importante é que a produção aumente e que tenha qualidade, sem que se considerem o trabalhador e as condições de trabalho.

As autoras afirmam que é fundamental uma formação geral e específica, para dar ao trabalhador condições, para a contraposição da realidade social, pois entendemos a educação como um processo que possibilita ao indivíduo tomar consciência de si própio e do mundo em que está inserido. Sabemos, todavia, que apenas isso não é suficiente para a transformação dessa realidade. Entendemos que o exercício da mudança implica o entendimento da qualificação para o trabalho, como uma relação social, muito além da escolaridade. Por que motivo faz-se necessária uma ação política que favoreça o seu desenvolvimento.

Para que exista uma relação interativa e fértil, entre trabalho e educação, é indispensável superar a noção de que a educação tem um objeto em si mesma e, portanto, subordina o trabalho, outro pólo da relação. A educação deveria, ao contrário, criar indivíduos, comunidades, grupos sociais, povos, capazes de maximizar a utilização dos seus potenciais e recursos físicos e humanos, de forma solidária nas relações sociais e harmônicas na relação com a natureza; isso os faria capazes de se auto-governarem e governarem coletivamente as suas diversas unidades de trabalho e de existência, da mais universal e geral a mais local e específica, de maneira libertadora.

É indispensável também, questionar a noção reducionista e utilitária, que submete o trabalho à produção material da subsistência e a educação a uma função social seletiva e especializada daquela produção.

Manacorda (2000), analisando a teoria de Marx e a pedagogia moderna, afirma que o advento da moderna revolução industrial faz surgir o fato verdadeiramente novo a estruturação da formação do produtor como "escola" ou lugar dos jovens. Essa organização não se ocupa mais de determinadas classes, mas de toda a sociedade civil, por meio do 
Estado. Não há dúvidas de que esse moderno processo de desenvolvimento envolveu também a estrutura escolar tradicional, introduzindo nela, amplamente, seus conteúdos científicos, dando-lhes um caráter não apenas cognitivo, mas também operativo. Foi nesse nível metodológico-histórico em que se pôde produzir a separação entre a escola do doutor e a escola do trabalhador: a primeira, acentuadamente livresca e desinteressada; a segunda, acentuadamente profissional e prática; mas ambas, definitivamente, escolas.

O mesmo autor, Manacorda (2000, p. 123) adverte para o fato de,

Fora da tradição marxista é, portanto, conhecida a incapacidade de inserir o pensamento pedagógico marxiano na história da pedagogia. Mesmo quando o inserem de algum modo, tende-se a integrá-lo, sem suficiente diferenciação entre as correntes mais conhecidas, desde o socialismo utópico, até o evolucionismo, o positivismo ou o pragmatismo, baseados em analogias mais formais que substanciais.

Observa-se que a prática que Marx tem em mente é algo que não coincide com o objetivo individual de validade do pensamento vigente, mas sim, com a prática de transformação do mundo. Trata-se de uma atividade na qual a sociedade humana está fortemente empenhada e que representa de certa maneira, todo o processo da sua história. A apropriação da natureza de modo universal, consciente e voluntário, sua modificação, ao modificar a natureza e seu próprio comportamento em relação a ela, modificando a si próprio como homem.

Ora, se a pedagogia moderna envolve relações de poder, a união de ensino e trabalho, bem como implementação de processos educativos, ricos em conteúdos teóricos, no coração da produção moderna, não é tarefa fácil. Aparece aqui, ainda, a importância da organização dos trabalhadores nas suas próprias unidades produtivas, com relativa autonomia e efetiva articulação, de modo que possam ir vivendo no seu dia-a-dia, os potenciais de imaginação, criatividade e solidariedade, em uma prática educativa concreta. Dessas vivências que 
emergirá a nova práxis democrática, capaz de gerar novas atitudes e comportamentos, entre eles e a transformação radical das estruturas e instituições em que atuam.

\subsection{4 - A educação como instrumento da promoção em saúde}

Na carta de Ottawa conceitua-se a promoção da saúde "como o processo de capacitação da comunidade, para atuar na melhoria da sua qualidade de vida e saúde, incluindo uma maior participação no controle deste processo". Assim definida e priorizada, a promoção da saúde não é responsabilidade exclusiva do setor saúde, mas vai além dos cuidados de saúde e de um estilo de vida saudável, na direção de um bem estar global. Também apóia o desenvolvimento pessoal e social, por meio da divulgação de informação, educação para a saúde e intensificação das habilidades vitais. Porém, foi a partir de 1992, após a Conferência de Santa Fé de Bogotá, que a promoção da saúde passou a ocupar um espaço destacado na agenda das políticas públicas (BRASIL, 1996).

Então, promover a Saúde passou a ser um desafio, principalmente, porque o poder econômico exercido, sem restrições em todos os setores e por longos períodos, forçou a constituição de um sistema de atenção á saúde, baseado na medicalização, tornando o culto à doença um forte elemento cultural da nossa sociedade. Médicos, hospitais, tecnologias e medicamentos, gradativamente cada vez mais modernos e, por conseqüência, mais onerosos, não levavam em conta as necessidades de saúde da população brasileira. Habitavam o imaginário social, formas de produção e conservação da saúde. Existem cinco áreas de atuação: elaboração e implementação de políticas públicas saudáveis; criação de ambientes favoráveis à saúde; reforço da ação comunitária; desenvolvimento de habilidades pessoais e reorientação do sistema de saúde (BRASIL, 2000 c). 
Em contrapartida, as profundas transformações observadas na sociedade brasileira, nos últimos quarenta anos, aconteceram, seguindo o curso aleatório da história. Não contou com o devido apoio de um projeto de desenvolvimento nacional que compatibilizasse o crescimento urbano com a qualidade de vida das populações recém-urbanizadas. Este aspecto, entre outros igualmente importantes, tornou-se fonte de estresse social considerável, fomentando o aparecimento de um sem-número de patologias físicas e mentais na comunidade.

No Brasil, o movimento pela reforma do setor saúde, conhecido como reforma sanitária, surgiu e foi ganhando força, à medida que os movimentos mundiais apontavam para a necessidade de políticas de saúde da população e para a oferta de oportunidades e recursos iguais ao acesso dos serviços de saúde (BRASIL, 2000 c).

Em inúmeros pontos do país, surgiram iniciativas e desenvolveram-se experiências, lideradas por universidades, organizações da sociedade civil e administrações municipais. Dentre elas, destacam-se o Programa de Agentes Comunitários de Saúde do Ceará, cujos fundamentos serviram de base à estrutura do Programa de Agentes Comunitários de Saúde (PAC's), criado pelo Ministério da Saúde, em 1991. A esse respeito, isso veio reforçar e ampliar a atuação desses Agentes, a experiência da Escola Nacional de Saúde Pública na comunidade de Manguinhos e a atuação do componente Informação, Educação e Comunicação (IEC), integrante do Projeto Nordeste, iniciativas desenvolvidas no âmbito do Ministério da Saúde, direcionadas à promoção da saúde (BRASIL, 2000 c). 
Nesse contexto, promover a saúde não implica, necessariamente, o desenvolvimento de ações inéditas. Ao contrário, o re-direcionamento do foco das políticas de saúde, buscando o seu fortalecimento e sua ampliação, por meio de parcerias e da participação popular, considerando o conceito abrangente de melhoria da qualidade de vida, na inserção dos componentes de comunicação e educação em saúde, como qualificadores das práticas de saúde.

A promoção da saúde se adequou a essa realidade sanitária à medida que oferece condições e instrumentos para uma ação integrada e multidisciplinar que inclui as diferentes dimensões da experiência humana - a subjetiva, a social, a política, a econômica e a cultural; portanto, coloca a serviço da saúde, os saberes produzidos nos diferentes campos do conhecimento.

Para Candeias (1997), promoção significa uma combinação de apoios educacionais e ambientais que visam atingir ações e condições de vida conducentes à saúde. Combinação refere-se à necessidade de mesclar os múltiplos determinantes da saúde (fatores genéticos, serviços de saúde e estilo de vida) com múltiplas intervenções ou fontes de apoio. Dessa maneira, saúde pode ser traduzida como a capacidade de enfrentar e modificar as condições que geram a situação de vida infra-humana e a doença.

Estudos de Buss (1998) sobre a promoção da saúde permitem-nos uma compreensão do aparecimento e evolução desse tema, como um movimento social e de profissionais de saúde, oriundo da reação à acentuada medicalização da saúde, na sociedade e no interior do sistema de saúde.

Esse autor revela que a promoção está associada, inicialmente, a um conjunto de valores como a vida, saúde, solidariedade, eqüidade, democracia, cidadania, e o desenvolvimento, participação, parceria, entre outros. Afirma, ainda, que é de 
responsabilidade de vários setores da sociedade, do Estado, da comunidade, do sistema de saúde e dos próprios usuários.

Portanto, a promoção pretende ser um novo olhar sobre a saúde e a doença. Configurase também, como mudança social significativa, rumo a uma sociedade menos consumista e mais justa, cujo objeto é a saúde, definida: "é a capacidade de vida diária [...] um conceito positivo que enfatiza os recursos sociais e pessoais, bem como capacidades físicas" (BRASIL, 1996).

Com as mudanças atuais é possível dar mais atenção ao aspecto positivo da saúde, papel fundamental da promoção. Neste sentido, Breslow (1999, p. 2256) nos revela que

Desse modo, a sociedade parece estar entrando em uma terceira "revolução da saúde pública". Terris observou que a primeira revolução da saúde pública lidou com as doenças transmissíveis e a segunda, com doenças crônicas, não transmissíveis. Embora nenhuma dessas revoluções tenha conseguido alcançar seu potencial completo, foram feitos progressos tão acentuados contra as doenças que agora pode ser devotada alguma energia para melhorar a saúde em termos de maximizá-la como recurso para a vida.

Nesse aspecto, de acordo com Lefrève (2000), a informação é peça-chave, pois procura aproximar o sujeito, tanto em nível individual, quanto coletivo, de sua doença; assim, conscientizá-lo de sua susceptibilidade pessoal e sociocultural.

Segundo Buss (1998), a educação em saúde é um componente essencial a ser utilizado na promoção da saúde.

Chor e Faerstein (2000), ao estudarem o enfoque epidemiológico da promoção da saúde, colocam que há uma forte relação entre os comportamentos populacionais médios e os desviantes, como resultado da dinâmica entre forças biológicas e sociais, que favorecem ou limitam a diversidade de características individuais. Assim, o risco de alguns agravos, em populações concretas, torna-se alto ou baixo em virtude do deslocamento em bloco da 
distribuição populacional, e não em função do número de indivíduos na faixa de alto risco. No final, entendemos que esses conceitos favorecem estratégias voltadas para o conjunto da população.

Czeresnia (1999) coloca a importância de diferenciarmos prevenção de promoção. A prevenção está associada ao discurso tradicional da saúde pública, e promoção, a uma idéia dentro da qual propostas estão sendo apresentadas, para repensar e redirecionar as práticas em saúde pública. Essa perspectiva concretiza os limites dos conceitos da saúde e da doença, em relação à experiência concreta que elas apresentam.

Por esse motivo, aparece à primeira característica importante da promoção em saúde: ou seja, o adoecer é entendido como um processo que relaciona vários fatores. Outra característica importante colocada é o olhar sobre a coletividade, a ação concreta que deve visar ao conjunto da população, como já explicitado anteriormente. Ainda, que o modelo é participativo, a metodologia é facilitadora, cujo objetivo principal é a mudança de ambiente.

Outra consideração importante: enquanto a prevenção for provisória, a promoção visará à eliminação permanente ou, pelo menos, duradoura da doença, porque buscará atingir as causas; não, apenas, evitar que as doenças se manifestem nos indivíduos (LEFÉVRE, 2000). 
Concordamos com esta idéia e colocamos esquematicamente, logo a seguir, no quadro

2.

\begin{tabular}{|l|l|l|}
\hline \multicolumn{2}{|c|}{ AÇÕES DE SAÚDE } \\
\hline Conduta & Promoção & Prevenção \\
\hline Ação & Geral & Patologia específica \\
\hline Grupo Focal & Toda População & Grupos de Risco \\
\hline Modelo & Participativo & Profissionais de Saúde \\
\hline Objeto & Saúde & Doença \\
\hline Método & Facilitação & Direcionadas e Persuasivas \\
\hline Objetivo Final & Capacitação & Mudanças de Comportamento \\
\hline Grupo Operacional & Mudança & Profissionais de Saúde \\
\hline
\end{tabular}

Quadro 2 Ações de saúde, promoção e prevenção

Dessa maneira, o modelo é participativo e o método exige capacitação, cujas estratégias e procedimentos não estão centrados somente nos profissionais da saúde, mas sim nos diversos órgãos, para que se alcance o objeto, a saúde, ou melhor, a promoção da saúde, que pode ser aqui entendida como prática social e como medida que vise melhorar as condições de um indivíduo ou grupo, antes da ocorrência de qualquer evento de doença.

É necessário dizer que percebemos a pedagogia problematizadora, como uma possível contribuição para a construção e a reconstrução crítica dos conceitos de promoção à saúde e 
do saneamento, à medida que incorpora o discurso dialógico e processual de uma certa comunidade.

Nesse sentido, consideramos importante sistematizar e fundamentar a prática educativa em relação à saúde e ao trabalho. A questão posta seria a de compreender o processo educativo no contexto da saúde do trabalhador, através da Comissão Interna de Prevenção de Acidentes (CIPA), em uma empresa do gênero alimentício em Ribeirão Preto.

Assim, ao tomamos, por objeto de investigação a CIPA, como instância educadora, isto é, a vinculação entre trabalho-educação, ou entre educação-trabalho, numa relação de oposição e de complementariedade, gostaríamos de reafirmar a opção e a base teóricometodológica, que constituí, o eixo desta investigação; no caso, o materialismo históricodialético. Essa investigação trata disso e defende a idéia de que o trabalho e a CIPA podem/devem ser fonte de educação em saúde.

Explicitadas as razões da escolha do objeto, definido o objeto e os objetivos da investigação, descrevemos o percurso metodológico, eleito para a sua compreensão. 


\section{4- O CAMINHO TEÓRICO-METODOLÓGICO}

\section{1- A pesquisa qualitativa e o estudo de caso}

A pesquisa em educação, saúde e trabalho é bastante complexa. Portanto, nos utilizamos da metodologia qualitativa, por ser a mais adequada ao atendimento dos objetivos propostos, na medida em que possibilita apreender os fenômenos na sua totalidade, visando enriquecer a questão, direcionando a reflexão sobre a realidade, a fim de transformá-la.

Para Ludke e André (1986), a pesquisa qualitativa "envolve a obtenção de dados descritivos, obtidos no contato direto do pesquisador com a situação estudada, enfatiza mais o processo do que o produto e preocupa-se em retratar a perspectiva dos participantes".

Chizzotti (2003, p. 79) afirma que:

A pesquisa qualitativa é uma designação que abriga correntes de pesquisa muito diferentes. Um marco que separa a pesquisa qualitativa dos estudos experimentais está na forma como apreende e legitima os conhecimentos. A abordagem qualitativa parte do fundamento de que há uma relação dinâmica entre o mundo real e o sujeito, uma interdependência viva entre o sujeito e o objeto, um vínculo indissociável entre o mundo objetivo e a subjetividade do sujeito. $\mathrm{O}$ conhecimento não se reduz a um rol de dados isolados, conectados por uma teoria explicativa; o sujeito-observador é parte integrante do processo de conhecimento, e interpreta os fenômenos, atribuindo-lhes um significado. O objeto não é um dado inerte e neutro; está possuído de significados e relações que sujeitos concretos criam em suas ações.

Bogdan e Biklen (1982) afirmam que, na pesquisa qualitativa, o estudo deve ser realizado no ambiente onde ele ocorre; os dados são provenientes de várias fontes; o ponto de vista dos sujeitos deve ser valorizado, buscando iluminar o processo de análise; a análise dos dados é construída gradativamente. 
Minayo (1998) aponta como características da abordagem qualitativa: a possibilidade de captar aspectos subjetivos do fenômeno que são impossíveis de serem sintetizados em dados estatísticos, pois a aglomeração dos dados pode ocultar ou falsear a existência de fenômenos de relevância; a possibilidade de incorporar a questão do significado e da intencionalidade dos agentes; compreensão do fenômeno como totalidade, possuindo abrangência multidisciplinar e estratégica.

Triviños (1988) refere-se a Wilson, Bogdan, Hymes e Lofland, compartilhando o ponto de vista de que a pesquisa qualitativa tem suas raízes nas práticas desenvolvidas pelos antropólogos, primeiramente; em seguida, pelos sociólogos, em seus estudos sobre a vida em comunidades; só, posteriormente, surge na investigação educacional.

O mesmo autor afirma que, na pesquisa qualitativa, considera válido o ponto de vista crítico-participativo, sob visão histórico-estrutural, para nossa realidade social, em razão de ser capaz de assinalar as causas e as conseqüências dos problemas, sua contradição, suas relações, suas qualidades, dimensões quantitativas, se houver, e realizar, por meio da ação, um processo de transformação da realidade que interessa.

Várias opções podem ser tomadas em relação à metodologia qualitativa. Aqui, optamos pelo método do estudo de caso, que resulta da seguinte concepção: além de constituir-se em uma das principais modalidades de pesquisa qualitativa, ele possibilita a realização de uma análise holística do objeto de estudo (GOLDENBERG, 1998; GIL, 1999).

O estudo de caso é um método útil, para estudar situações particulares dentro de um contexto mais amplo. Também objetiva descobrir elementos novos que podem surgir, no decorrer do estudo, assim como valoriza as relações inter-pessoais e o contexto histórico e político em que o estudo está inserido; por meio da análise gradual, permite chegar a generalizações (BOGDAN e BIKLEN,1982). Constitui um método reconhecido, em várias áreas do conhecimento, como a medicina, a psicologia, o direito. 
Chizzotti (2003, p. 102) destaca que

O caso é tomado como unidade significativa do todo e, por isso, suficiente, tanto para fundamentar um julgamento fidedigno, quanto propor uma intervenção. É considerado também como um marco de referência de complexas condições socioculturais que envolvem uma situação e tanto retrata uma realidade, quanto revela a multiplicidade de aspectos globais presentes em uma dada situação.

Com essa finalidade, Bourdieu (1989) destaca a importância da interrogação sistemática de um caso particular, para retirar dele as propriedades gerais, ou invariantes, ocultas debaixo das aparências de singularidade.

Verifica-se que o estudo de caso tem como fases: a fase exploratória; a coleta de dados e a interpretação dos dados, assim como elaboração de relatório (CHIZZOTTI, 2003). Estas fases se relacionam entre si a todo o momento, pois, se trata de uma investigação que vai se constituir na realização à medida que proporciona a reflexão sobre a própria prática, transformando-a em objeto de investigação, o que pressupõe um constante ir e vir por parte dos sujeitos e atores nela imersos.

Por suas especificidades, o relacionamento de dois objetivos, um que é prático e o Formatados: Marcadores e numeração outro que é de produção de conhecimento, este trabalho, deverá trazer contribuições, tanto à empresa na qual ele se realizou, quanto ao meio acadêmico. Essa é uma preocupação da autora, ou seja, a de realizar um trabalho que seja prático, no sentido de utilidade, pois entendo que a ciência deve contribuir para a construção de melhorias nas condições de vida das pessoas.

A metodologia da pesquisa social no campo da educação em saúde, sob o enfoque dialético, não depende apenas do conhecimento técnico; logo, buscamos valorizar uma postura intelectual, uma visão social da realidade e uma prática capaz de ir além dos fatos e das verdades. Segundo Frigotto (1998) e Minayo (1998), estão contidos nos esquemas 
abstratos de determinações gerais, exigindo que o pesquisador faça a ruptura com a ideologia dominante.

Assim, em uma perspectiva dialética, como lógica e teoria do conhecimento, a razão parte dos fenômenos para a essência, das partes para o todo, buscando, assim, uma superação. Ela surgiu há muito com o Tao Te King, Zenão, Heráclito de Éfeso, Sócrates, Platão e Rousseau, considerados dialéticos em sua forma de exporem as idéias. Além deles, em Marx e Engels, a dialética começa a assumir um status filosófico (o materialismo dialético) e científico (o materialismo histórico)-, por meio da qual, captar a essência do processo educativo, no que diz respeito á saúde do trabalhador.

Gadotti (1992), referindo-se à concepção da dialética como "arma de luta", configura uma teoria engajada, na produção da ciência, comprometida com a transformação da sociedade. Essa concepção serve à elaboração do pensamento crítico e autocrítico e ao questionamento da realidade presente. Esse movimento dialético, que definimos como movimento de oposição dos contrários, opera-se o tempo todo e em toda parte. Inclui no seu método, categorias metodológicas (a práxis, a totalidade, a contradição, e a mediação) que definem a forma de investigar o objeto, e são portanto, "leis universais", uma constante neste estudo; categorias de conteúdo (o trabalho, e a educação em saúde, por meio das concepções e ações educativas da CIPA, SIPAT's e do SESMT) que definem a forma de análise específicas para cada objeto, a partir dos objetivos; são, portanto, "leis particulares".

Vale esclarecer que, por práxis, entendemos o princípio do movimento em que tudo se transforma o tempo todo; por totalidade, compreendemos que as partes fazem parte do todo e o todo se cria a si mesmo na interação com as partes; por contradição, temos a unidade e luta dos contrários, lei fundamental da dialética; e finalmente a mediação, princípio da mudança qualitativa, significando que, ao ocorrer uma transformação, ela se dá do quantitativo para o qualitativo e do qualitativo para o quantitativo. Neste estudo, adotamos tanto as categorias 
metodológicas, quanto as categorias de conteúdo acima abordadas, para a apreensão de nosso objeto de estudo, qual seja, a educação em saúde nos ambientes de trabalho. Ao serem relacionadas, têm-se as categorias do estudo do processo de educação em saúde do trabalhador em uma empresa de Ribeirão Preto, SP, que foram as seguintes: a CIPA, segundo os "cipeiros"; a educação em saúde do trabalhador na CIPA, na realidade da empresa, ainda, a relação educação e trabalho nessa empresa, divididas em subcategorias.

Após essa explicitação, coloco algumas questões que surgiram antes mesmo de iniciar este trabalho científico, ou, talvez, constituíram à força-motriz para que eu pudesse começálo:

Será que aprendemos essencialmente, a partir da repetição de conhecimentos, ou pudemos empreender uma prática inovadora nas empresas, que possibilitou a expansão das potencialidades dos sujeitos/trabalhadores desenvolverem uma visão ampliada da realidade em que vivem, e trabalham, gerando possibilidades de intervenção?

Daí, as perguntas: por que é importante produzir conhecimento sobre saúde? Qual o seu alcance? Por que identificar os novos espaços e atores pedagógicos, responsáveis pelos processos de educação dos trabalhadores?

Minayo et al. (2000) consideram que o método para explorar uma realidade, marcada pela especificidade e pela diferenciação, deve ser fundado numa partilha de princípios e não de procedimentos. Assim sendo, o que propomos a seguir são as etapas de exploração de campo.

A pormenorização minuciosa do percurso metodológico que apresentamos a seguir tem três finalidades principais: a) descrever os procedimentos e suportes teóricos e técnicos para a compreensão do cenário da pesquisa, do objeto de estudo, dos sujeitos sociais envolvidos e dos instrumentos para a coleta e análise dos dados; b) apresentar a forma de encaminhamento da investigação, focalizando o seu caráter dialético que possibilitou a 
interação com a realidade e a superação de problemas e contradições; c) articular a metodologia à discussão do tema e à abordagem conceitual da pesquisa.

\section{2 - Fase exploratória}

A fase exploratória da pesquisa é tão importante que, por suas características, pode ser considerada uma pesquisa exploratória. Compreende a etapa de escolha do tópico da investigação, da delimitação do problema, da definição do objeto e dos objetivos, da construção do marco teórico conceitual, dos instrumentos de coleta de dados e da exploração do campo.

A partir da perspectiva dialética que desejamos seguir, gostaríamos de apresentar marcos, dentro dos quais, sob o nosso ponto de vista, se processa-se o conhecimento, segundo Minayo (1998).

A primeira delas é seu caráter de aproximação. Isto é, o conhecimento é uma construção que se faz, a partir de outros conhecimentos sobre os quais se exercita a apreensão, a crítica e a dúvida. O segundo ponto diz respeito ao caráter de inacessibilidade do objeto. A inatingibilidade do objeto se explica pelo fato de que as idéias que fazemos sobre os fatos serem mais imprecisas que eles. Logo, o processo de pesquisa consiste na definição e redefinição do objeto. De um lado, porque seu conhecimento é fruto de um exercício de cooperação, onde trabalhamos sobre as descobertas uns dos outros; de outro, porque cada teoria formula o objeto, conforme seus pressupostos.

Finalmente, o terceiro ponto se refere à vinculação entre pensamento e ação. Ou seja, nada pode ser intelectualmente um problema, se não tiver sido, em primeira instância, um problema da vida prática. Isto quer dizer que a escolha de um tema não emerge espontaneamente, da mesma forma que o conhecimento não é espontâneo. Surge de interesses 
e circunstâncias socialmente condicionadas, frutos de determinada inserção no real, nele encontrando suas razões e seus objetivos.

Dentro dessa perspectiva abordada, passamos a discutir elementos que compõem a fase exploratória desta investigação, bem como todas etapas subseqüentes.

Nesse movimento aparentemente linear de desenho das etapas da pesquisa, queremos enfatizar, por um lado, a necessidade, para fins de análise, da atenção a cada procedimento; por outro, a liberdade de reconhecer as diferentes técnicas e métodos, como guias, prescindindo deles, quando se tornarem obstáculos. É nessa interação que se torna possível a realização de um trabalho científico criador.

Nessa fase, a preocupação da pesquisadora voltou-se para "conhecer o terreno", ou seja, situar-se no contexto em que a pesquisa se desenvolveu, a fim de obter os dados que a ajudassem, na elaboração de critérios de seleção dos sujeitos e das categorias selecionadas.

Dessa maneira, fizemos a observação simples, por meio do mapeamento dos setores de trabalho da empresa e o registro em diário de campo, pretendendo nesse lugar, conhecer melhor os processos de trabalho nos diferentes setores da empresa.

A esse respeito, cabe aqui, esclarecer que, anteriormente, em 2001, realizei, juntamente com outras pesquisadoras, trabalho de campo nessa mesma empresa, buscando estudar a política de alimentação do trabalhador (ALESSI et al., 2001); apesar de ter utilizado parte daquela investigação, busquei ampliar a observação, por entendê-la como fundamental para a apreensão das cargas laborais, presentes nessa empresa, correlacionando-as aos impactos da saúde dos trabalhadores.

Fizemos ainda, nessa fase, o levantamento dos conteúdos da CIPA e SIPAT's, para que, em posse desses conhecimentos, pudéssemos passar à fase seguinte; a orientação para a coleta de dados. 


\section{3- Instrumentos e procedimentos de coleta de dados}

Sabendo que nenhum método pode abranger todas as possibilidades no contexto de um grupo, utilizamo-nos, nessa fase, de anotações provenientes das reuniões da CIPA, análise documental das atas dessa comissão, aplicação de questionários, e uma revisão bibliográfica cuidadosa, concernentes ao tema. Essas estratégias compõem a abordagem metodológica, mediante a qual um grupo de sujeitos pode ser investigado a respeito de uma experiência educacional que está sendo vivenciada.

A observação consiste em uma estratégia valiosa no campo da pesquisa qualitativa, já que permite um contato em que a pesquisadora poderá perceber mais diretamente as interfaces do fenômeno em questão. Em razão disso, a pesquisadora teve, por vezes, o papel de observadora simples no mapeamento dos setores de trabalho, bem como o de observadora participante (ANEXO A). Nesse caso, as características do grupo foram devidamente registradas em um diário de campo. Cabe aqui esclarecer que este momento investigativo pressupõe o entendimento dos processos de trabalho característicos da produção industrial da empresa, tendo sido realizado com base nas Normas Regulamentadoras do Trabalho (NR's) e no referencial teórico-metodológico sistematizado por Laurell e Noriega (1989) que concebem o objeto saúde e trabalho como processo social.

Os questionários complementaram as informações que ainda não tinham sido apreendidas na observação. No momento da coleta de dados, o questionário aberto e o fechado elaborados puderam ser instrumentos valiosos, para a complementação das questões colocadas nos objetivos, que, ainda, não haviam ficado claras com as demais estratégias. Desse modo, procuramos elaborar questões abrangentes que nos dessem meios de analisar a CIPA, como também seu papel na educação em saúde do trabalhador na empresa estudada (ANEXO B). 
A análise documental também complementou informações que necessitavam ser esclarecidas. Aqui foram analisados as NR's, em relação à questão da educação em saúde no contexto das CIPA's, as atas das reuniões ocorridas no tempo de existência da CIPA, os conteúdos da SIPAT's, bem como os documentos “produzidos" pelo SESMT (o Programa de Controle Médico em Saúde Ocupacional 'PCMSO' e o Programa de Prevenção de Riscos Ocupacionais 'PPRA' ) da empresa.

Em síntese, foram considerados dados da pesquisa: a) anotações dos conteúdos das reuniões da CIPA, no diário de campo da pesquisadora; b) observação dos processos de trabalho; c) questionários devidamente preenchidos pelos participantes e d) documentos.

Nesse particular, entendemos que as técnicas apontadas anteriormente contribuíram para atingir os objetivos propostos neste trabalho de pesquisa, pois compreenderam um conjunto de estratégias definidas e direcionadas para um determinado fim, a compreensão da dimensão da promoção à saúde, contida na prática educativa em saúde dos membros de uma CIPA de empresa, ligada à produção de alimentos, em Ribeirão Preto (SP).

\subsection{1- O diário de campo}

Em nossa pesquisa, dentre os instrumentos utilizados para coleta de dados, privilegiamos o diário de campo, onde foram registradas, de forma sistemática, todas as atividades realizadas.

As atividades eram registradas sempre, após a finalização, elaboradas em um caderno pautado e paginado, no qual a atividade era descrita minuciosamente, constituindo-se em documento pessoal e intransferível, por conter o registro cotidiano do trabalho de campo.

Além das descrições factuais, lançamos nele as percepções, emoções, dúvidas, questionamentos da pesquisadora e as informações obtidas, por meio através da observação 
participante, bem como das conclusões e planejamentos que serviram no momento de análise das respostas dadas pelos "cipeiros".

Em relação às posturas adotadas, pude perceber abertura dos "cipeiros", em relação às propostas que surgiam nas reuniões da CIPA. No que diz respeito à realização delas, pude observar que, geralmente, os trabalhadores manifestam interesse em participar das reuniões, porém, às vezes, as chefias em consequiência da pressão de trabalho interno, muitas vezes não os liberavam para a atividade fosse realizada, inviabilizando as propostas. Estas duas observações serão mais bem analisadas no decorrer do trabalho.

\subsection{2- A aproximação do grupo}

A aproximação com o grupo aconteceu sem resistências, uma vez que a pesquisadora já conhecia todos os "cipeiros", por ser a médica do trabalho da empresa. Por esse motivo, já tinha estabelecido um contato prévio, durante as consultas médicas, ou, durante a participação deles, em eventos educacionais, promovidos pelo Serviço Especializado em Segurança e Medicina do Trabalho (SESMT).

Após a aprovação do projeto de pesquisa na empresa, efetivada pela diretoria, o relacionamento entre a pesquisadora e os "cipeiros" foi intermediado pelo técnico de segurança do trabalho, em exercício, na época. Ele também mostrou interesse em estreitar a

ligação entre o SESMT e a CIPA, como também, conhecer o universo dos "cipeiros", um dos objetivos desta pesquisa.

Freire (1987, p. 49) refere-se a esta fase, dizendo que,

[...] os investigadores necessitam obter que um número significativo de pessoas aceite uma conversa informal com eles, em que lhe falarão dos objetivos de sua presença na área. No qual dirão o porquê, o como e para quê da investigação que pretendem realizar e que não podem 
fazê-lo se não se estabelece uma relação de simpatia e confiança mútuas [...] Desta forma, esta fase se inicia com um diálogo às claras entre todos.

Utilizamos a observação participante, quando houve a inserção nas reuniões da CIPA; Ludke e André (1986) descrevem inúmeras vantagens do trabalho de observação na pesquisa qualitativa, que, além de apresentar um lugar privilegiado nas abordagens de pesquisa educacional, possibilita um contato pessoal direto do pesquisador com o fenômeno pesquisado. Além disso, permite que o pesquisador chegue mais perto da perspectiva dos sujeitos. Quando trata deste assunto, Chizzotti (2003) reafirma as ponderações anteriores, ressaltando que, embora tenha sido duramente contestada pelas pesquisas experimentais na década de 20 e abandonada por algumas décadas, o ressurgimento da observação participante em pesquisa tem auxiliado nas interpretações mais globais das situações analisadas.

Romanelli (1998, p. 128) afirma que

A subjetividade, elemento constitutivo da autoridade presente na relação de sujeitos, não pode ser expulsa, nem evitada, mas deve ser admitida e explicitada e, assim, controlada pelos recursos teóricos e metodológicos do pesquisador, vale dizer, da experiência que ele lentamente vai adquirindo no trabalho de campo.

Verifica-se que a observação foi possível, graças à sua inserção na pesquisa qualitativa, que valoriza o ponto de vista do sujeito para a captação do significado. Na participação da pesquisadora em algumas reuniões da CIPA, foi realizada uma explicitação pormenorizada do estudo, seus objetivos, meios e fins, bem como incursões sobre questões abordadas nas reuniões e anotações no diário de campo.

\subsection{3- Participantes do estudo}


A população foi composta por um grupo de profissionais que constituem a CIPA, em uma empresa privada de Ribeirão Preto, por entendermos que a questão da educação em saúde na área da saúde do trabalhador passa pela CIPA e SIPAT, promovida anualmente pela CIPA.

A população deste estudo foi abordada nas reuniões da CIPA, utilizando o critério da representatividade qualitativa como critério de seleção, bem como a crença de que a CIPA deve representar os trabalhadores no local onde está inserida.

Respeitamos também o critério do consenso da pesquisadora e dos participantes, e mais o critério de confiança no profissional, uma vez que já se tinha estabelecido um vínculo de respeito mútuo entre os profissionais envolvidos no estudo. Mesmo sabendo que, nas relações e processos grupais, o conflito está presente, entendo que o profissional que não conseguir adesão, e que não respeitar o grupo, não conseguirá a participação ou motivação para a continuidade do trabalho, pois a educação é um saber-fazer que só acontece no convívio social.

O tempo de duração do trabalho de campo foi de 2 anos, incluindo aqui a leitura das atas das reuniões da CIPA, o mapeamento dos setores de trabalho, a observação e as outras técnicas de coletas de dados propostos.

A questão ética também foi motivo de preocupação por parte da pesquisadora. Nesse sentido, a autorização para esta pesquisa foi efetuada, mediante a assinatura de um termo de consentimento por parte dos participantes do estudo (ANEXO C).

\subsection{4- A Observação dos processos de trabalho}

A observação permite ao pesquisador ter contato direto com os sujeitos. Em nosso caso, além disso, entendemos que a análise do processo de trabalho permitiu-nos identificar os 
conhecimentos que o estruturam, as cargas laborais, os instrumentos, meios e a sua organização, para que assim também pudéssemos verificar o perfil epidemiológico, em relação aos acidentes nessa empresa, bem como relacionar as atividades, e os temas da CIPA e SIPAT's à realidade dessa empresa.

Conforme já mencionado anteriormente, a descrição do ambiente de trabalho provém de dados levantados em uma outra pesquisa anterior, complementados pela pesquisadora de outros que se fizeram necessários. Elaboramos, como dito anteriormente, um roteiro de observação (ANEXO A) para os processos de trabalho. As sessões duraram em média 1 hora, e se realizaram, fora do expediente de trabalho da pesquisadora, no SESMT da empresa.

\subsection{5- A análise documental}

Nossa análise documental incidiu sobre as atas das reuniões da CIPA, colocadas no ANEXO D, e que serão discutidas no capítulo seguinte, com ênfase no processo educativo da CIPA, seus conceitos e práticas. No que diz respeito à programação das SIPAT's (ANEXO E), que também será discutida a seguir, focalizam os seus conteúdos e contribuições à educação em saúde do trabalhador; os diálogos de segurança, produzidos pelo SESMT (ANEXO F); e as leituras sistemáticas na sala de espera do ambulatório da empresa (ANEXO G), bem como o Programa de Controle Médico em Saúde Ocupacional (PCMSO) e o Programa de Prevenção de Riscos Ambientais (PPRA).

Vale ressaltar que, na época da realização desta investigação, a empresa estava em um momento de transição política e econômica; conseqüentemente, sob novas diretrizes administrativas e políticas. Era uma grande empresa que estava sendo comprada por outra grande empresa, entretanto do mesmo ramo, do setor alimentício.

Nessa fase da pesquisa exploratória, houve uma grande dispensa de funcionários, inclusive de membros da CIPA e mudança de tecnologia no ambiente fabril. Ainda, a 
implementação de uma nova filosofia de trabalho, colocada aos funcionários, inclusive aos membros da CIPA. Procedeu-se então, à alteração na gestão e organização do trabalho. Essas alterações, em implantação, parecem apontar para as diretrizes do processo de adequação da empresa ao atual processo de reestruturação produtiva em curso no país. Por essas razões, a educação tornava-se uma importante ferramenta de trabalho dentro da instituição empresarial, fundamental para a absorção da nova filosofia da empresa, sua política, visão e metas. A CIPA, no tocante à prevenção dos acidentes do trabalho, ganhou relevância, pois a nova direção considerava fundamental mudar o perfil dos acidentes do trabalho. No entanto, percebemos que essa proposta de mudança, por meio da educação, ocorreu dentro de uma perspectiva de controle do trabalhador. Tornava-se uma educação que visava à extensão de conceitos patronais, em detrimento da comunicação necessária para gerar consciência.

Então, em um primeiro momento, isso representou uma facilidade para nós, quanto à participação em reuniões da CIPA e conversas com os "cipeiros", pois a "nova" empresa tinha interesse em conhecer e destacar as ações da CIPA. Um pouco mais tarde (seis meses depois), transformou-se em dificuldade, pois nos foi dito que "não era momento de se mexer com questões polêmicas". Diante disso, optamos por sistematizar o que tínhamos obtido até aquele momento.

Passamos à fase de discussão e análise dos dados, porém, sem atingirmos plenamente o objetivo de problematizar algumas questões que entendíamos e, continuamos entendendo, pertinentes aos "cipeiros", como por exemplo: Como aumentar o nível de participação por parte dos trabalhadores e da empresa na CIPA e na SIPAT? Qual a ligação entre saúde e trabalho? Que dimensão deveria ter a educação nas ações da CIPA?

Ainda decorrentes de tais mudanças, surgiram naquele momento, dois fatos novos para a CIPA: uma nova constituição de seus membros e dois novos instrumentos "educativos", os 
diálogos de segurança e os folhetos sobre saúde, propostos pela nova diretoria e gerência regional, que assumiriam a função de padronizar condutas entre as unidades da empresa.

Em relação à constituição da CIPA, havia um total de 18 "cipeiros", entre os membros eleitos e indicados: 4 eram suplentes e 14 participavam ativamente, porém, destes 14, quatro saíram da empresa, e não foram substituídos. Em decorrência, a CIPA, neste novo momento, contava com 10 integrantes efetivos, na proporção de quatro para seis, entre indivíduos eleitos e indicados. Desse total de "cipeiros", 9 responderam ao questionário.

\section{4 - Processo e procedimentos de análise dos dados}

\subsection{1 - A organização do material recolhido: análise de conteúdo}

Procedemos à organização do material, sendo que esta fase baseou-se em Minayo (1998). Em vista da totalidade do material recolhido, procuramos as palavras ou frases dos "cipeiros" que fossem representativas das questões formuladas, tendo aparecido com mais frequiência ou tendo sido colocadas com maior ênfase, nas respostas aos questionários e nas reuniões da CIPA. Constituíram os núcleos de sentido, analisados no estudo; a seguir, selecionamos palavras ou frases que continham "viéses" de compreensão da realidade pelos “cipeiros", não entendidos como julgamento, "certo ou errado“, mas como dados de análise, diferenciando-os entre o senso comum e o científico.

A análise qualitativa dos dados permite buscar o significado mais profundo da compreensão particular daquilo que se pretende estudar. Portanto, com base nesse pressuposto, elegemos neste estudo, a análise de conteúdo, que segundo descrição de Minayo

(1998, p. 199), é “a expressão mais comumente usada para representar o tratamento dos dados de uma pesquisa qualitativa", ou ainda, segundo Chizzotti (2003, p. 98): “A análise de conteúdo é um método de tratamento e análise de informações, colhidas por meio de técnicas de coleta de dados, consubstanciadas em um documento". 
Bardin (1977, p. 29-42), autora que tem servido de referência a vários estudos que utilizam o método da análise de conteúdo dos dados de pesquisa, a define como,

Um conjunto de técnicas de análise das comunicações visando obter, por procedimentos sistemáticos e objetivos de descrição do conteúdo das mensagens, indicadores (quantitativos ou não) que permitam a inferência de conhecimentos relativos às condições de produção/recepção destas mensagens e, que [...] pretende compreender, para além dos significados imediatos das comunicações.

Compreender o sentido da comunicação como se fosse um receptor normal, mas também e, principalmente, "desviar" o olhar para uma outra significação, uma outra mensagem percebida através ou ao lado da mensagem primeira, é a dupla tentativa do analista ao fazer a leitura do conteúdo das comunicações. Não deve ser feita somente uma leitura "à letra", mas também uma leitura atenta ao sentido que se encontra em segundo plano, atingindo outros "significados" de natureza psicológica, sociológica, política, histórica, etc., implícitas nas mensagens (BARDIN, 1977).

No entanto, o termo "Análise de Conteúdo" significa mais do que um procedimento técnico, pois vem passando por transformações, e pode ser considerado um conceito "historicamente construído", com implicações teórico-metodológicas no campo das investigações sociais. O método adequa-se a um campo de aplicação extremamente vasto, pois, em última análise, qualquer comunicação (dita ou escrita), ou seja, qualquer transporte de significações de um emissor a um receptor, controlado ou não pelo primeiro, é susceptível de uma análise de conteúdo (MINAYO, 1998).

Bardin (1977, p. 81) diz que o gênero de resultados, obtidos pelas técnicas de análise de conteúdo, não pode ser tomado como prova inelutável. Mas constitui, apesar de tudo, "uma ilustração que permite corroborar, pelo menos parcialmente, os pressupostos em causa”. 
Assim, dentre as técnicas de análise de conteúdo, optamos pela análise temática. Nos pressupostos apresentados por Bardin (1977, p. 153), a análise temática ou categorial funciona por "operações de desmembramento do texto em unidades, em categorias segundo reagrupamentos analógicos". Entre as diferentes possibilidades de categorização, a investigação dos "temas" é rápida e eficaz na condição de se aplicar a discursos diretos (significações manifestas) e simples.

Para Minayo (1998), a noção de "tema" está ligada a uma afirmação a respeito de determinado assunto, que comporta um feixe de relações, e pode ser graficamente apresentada através de uma palavra, uma frase, um resumo.

Bardin (1977, p. 105) considera que "o tema é a unidade de significação que se liberta naturalmente de um texto analisado, segundo certos critérios relativos à teoria que serve de guia à leitura". Para ela, fazer uma análise temática consiste em descobrir os "núcleos de sentido" que compõem a comunicação expressa no discurso, fornecido pelas respostas a questões abertas, em entrevistas (não-diretivas ou semi-estruturadas) individuais ou de grupo, em reuniões de grupo, dentre outras técnicas de coleta de dados. O tema é geralmente utilizado, como unidade de registro, para estudar motivações de opiniões, de atitudes, de valores, de crenças, de tendências, encontradas nos discursos do material analisado.

Na concepção de Minayo (1998), realizar uma análise temática com enfoque qualitativo, implica considerar que a presença de determinados temas denota os valores de referência e os modelos de comportamento presentes no discurso. Com esse objetivo, operacionalmente, a análise temática desdobra-se em três etapas: 1) pré-análise; 2) exploração do material; 3) tratamento dos resultados obtidos e interpretação.

Assim sendo, pretendemos, neste caminhar, estarmos atentas e abertas às prováveis questões que puderam emergir do contato com tema, tão instigante e complexo, como a educação em saúde do trabalhador. 
Em se tratando de um trabalho de educação ou de uma atividade concreta de promoção à saúde, este tipo de estudo se valeu de instrumentos que lhe permitiram descrever a ocorrência das situações, segundo fatores com os quais estabelecia relações quantitativas (estatísticas numéricas), bem como da apreensão de relações qualitativas, já descritas nas estratégias anteriores.

Assim, a interpretação e a análise dos dados irão avaliar quanto o produto do trabalho de investigação correspondeu ao seu projeto (resultados finais do trabalho). Essa fase não se desvincula das demais e possui caráter processual e dinâmico. Segundo Minayo (1998), existem várias finalidades a serem atingidas nesse momento, englobando um entendimento dos dados apreendidos. Segue-se a constatação da resposta aos pressupostos e objetivos propostos, que, denotam clareza a respeito do objeto, o que amplia o conhecimento sobre ele relacionando-o ao contexto no qual estão inseridos.

Esse procedimento busca iluminar o processo de análise, a partir de um referencial teórico que leve em conta a fala dos sujeitos, considerando-os como pessoas em relação, que devem sempre estar situadas nos seus contextos históricos. Assim, o percurso consistiu na pré-análise, em que as informações foram lidas no conjunto, de forma a esgotar todo o material, conhecer todo o conteúdo e relacioná-lo à teoria. Na organização do material, houve cuidado, para que fossem respondidas às normas de: a) exaustividade (que contempla todos os aspectos levantados no roteiro); b) representatividade (que contém as representações do universo pretendido); c) homogeneidade (que obedeçe a critérios precisos de temas técnicos e interlocutores); e d) pertinência (documentos analisados, adequados ao objetivo do trabalho). A exploração do material constituiu da análise e interpretação dos dados, objetivando atingir o núcleo de compreensão de seu significado, ou seja, da operação de categorização dos temas identificados, descritos a seguir. 


\section{5- O PROCESSO EDUCATIVO EM SAÚDE DO TRABALHADOR EM UMA EMPRESA DE RIBEIRÃO PRETO, SÃO PAULO.}

Grande parte da produção científica nas áreas de medicina social e enfermagem, se inspira-se nos paradigmas das Ciências Humanas, privilegiando a compreensão positivista. Assim, considera explicações simplificadoras do objeto da área (ALESSI et al, 2001). Pretendemos, ao utilizar, o referencial teórico da epidemiologia social, fundamentado no materialismo histórico e dialético, que aplica aos problemas da saúde a dinâmica das relações de produção e o da pedagogia de Paulo Freire, ampliar a discussão do objeto: a educação em saúde do trabalhador na Comissão Interna de Prevenção de Acidentes (CIPA).

Reafirmamos que a pesquisa social, por ser essencialmente qualitativa, implica a utilização de técnicas que captem a idéia de construção, e não somente o que está dado; portanto, trabalha com o provisório, dinâmico, subjetivo e histórico. Nesse processo, privilegiamos os dados fundamentais para a compreensão do objeto de estudo, sem perder de vista a preocupação com a qualidade e o rigor metodológico da pesquisa. Assim, de acordo com Demo (1995, p. 34), procuramos tratar os dados, fazendo uma análise dos conteúdos da prática, "deixando-se em plano secundário a roupagem formal da elaboração discursiva".

Por ser a presente pesquisa, voltada à área de educação em saúde, concordamos com Minayo et al. (2000, p. 17), ao entenderem por pesquisa,

A atividade básica da Ciência na sua indagação e construção da realidade. É a pesquisa que alimenta a atividade de ensino e a atualiza frente à realidade do mundo. Portanto, embora seja uma prática teórica, a pesquisa vincula pensamento e ação. 
Essa autora afirma, ainda, que o campo da saúde se refere a uma realidade complexa, que demanda conhecimentos distintos integrados, colocando de forma imediata o problema da intervenção. Assim, requer uma abordagem dialética que compreende para transformar, cuja teoria, desafiada pela prática, deva repensá-la permanentemente. Em relação à educação, essa abordagem também se aplica, isto é, constitui uma área complexa, que exige reflexão aprofundada, com o intuito de captar sua real dimensão. Nesse quadro, para compreender o processo de educação em saúde dos trabalhadores de uma empresa, é necessário, inicialmente, caracterizar o contexto em que ele ocorre.

\subsection{A caracterização do ambiente de trabalho}

A caracterização da empresa foi realizada, por meio da observação dos processos de trabalho. A empresa eleita, como campo empírico, atua no ramo alimentício e conta com um quadro de 308 funcionários; de acordo com a NR-4, considerando o quadro de funcionários, a referida empresa classifica-se como de médio porte (BRASIL, 2000b).

Esta está dividida nas áreas administrativas, segurança e medicina do trabalho e da produção propriamente dita; esta área está localizada num galpão de 22.000 metros quadrados de área construída, em cujo interior encontram-se distribuídos os diversos setores que concorrem para a produção dos alimentos, acoplada de silos que alimentam de matérias-

primas os diversos setores da produção alimentícia (ANEXO H). As áreas dos serviços administrativos, da alimentação, e segurança e medicina do trabalho funcionam em prédios próprios, situados um pouco afastados das instalações da área de produção.

Do lado externo do galpão, encontram-se as instalações dos setores de mecânica, manutenção e almoxarifado, e, próximos delas, um gerador de energia e uma estação de tratamento de esgoto. Estes setores dão apoio direto à área de produção. No tocante à área de 
produção, ela é composta por 5 setores, quais sejam: recepção de matéria-prima; mistura, moinho e micro-nutrientes; sala de congelados; processo de produção; ensaque e embalagem e descarga dos produtos.

O setor de recepção e armazenamento de matérias-primas tem por função receber e armazenar as matérias-primas que chegam em caminhões, acondicionadas em sacos, com pesos entre 25 e $50 \mathrm{~kg}$, variação que depende do tipo de matéria-prima a ser utilizada na composição dos produtos finais. Funciona de $2^{\mathrm{a}}$ a $6^{\mathrm{a}}$ feira, cujos trabalhadores cumprem jornada de 8 horas diárias de trabalho.

Atuam no setor 6 trabalhadores que desempenham a atividade de descarregar as matérias-primas dos caminhões, organizando pilhas de sacos em cima de palets de madeira para serem transportadas por empilhadeiras e organizadas pelo tipo de matéria-prima. São dispostas, próximas do local de sua utilização, pelo processo de produção. Predomina o desenvolvimento de atividades manuais e o modo de ser do trabalho consiste em retirar dos caminhões os sacos de matéria-prima, com as mãos utilizando as costas, como veículo de transporte, até a organização das pilhas nos palets de madeira. Por dia, são descarregadas e organizadas 45 toneladas de matéria-prima, o que representa, em média, 7,5 toneladas por trabalhador.

Encontra-se no ambiente de trabalho, um conjunto de cargas laborais, destacando-se como cargas físicas, precária iluminação, calor intenso, ruído forte e contínuo, proveniente das empilhadeiras. Embora elas circulem em espaço com faixas de proteção, sua circulação contínua pode provocar acidentes. Como carga química, existe a presença de poeiras, provenientes dos sacos furados de matéria-prima. Como cargas fisiológicas, destacam-se os movimentos repetitivos dos braços, flexões da coluna e o carregamento de peso. No que concerne aos operadores de empilhadeiras, as constantes rotações do pescoço garantem que as manobras realizadas sejam seguras; e o trabalho contínuo, sentado, realiza-se por movimentos 
repetitivos dos membros inferiores e superiores. Como cargas psicológicas, destacam-se a fadiga e o stress, derivados da interação e atuação dos outros tipos de cargas no corpo e na mente dos trabalhadores. Acrescente-se a isso, outro fator, que é a espécie de trabalho, a perda contínua de líquidos e sais minerais, sendo que a seção não dispõe de bebedouro próximo, com água fresca que propicia a sua reposição. Esse modo de realização do trabalho nos leva a considerar que a atividade lá desenvolvida é do tipo intensa.

No final do espaço da área, encontra-se um laboratório de Garantia de Qualidade, onde são realizadas análises das matérias-primas e dos produtos alimentícios. O local está organizado, em diferentes salas, segundo os tipos de análises a serem realizadas. Dispõe de um conjunto de equipamentos de proteção coletiva (EPC), como extintores de incêndio, chuveiro, saída de emergência e faixas protetoras no chão, para a circulação. Como equipamentos de proteção individual (EPI), verifica-se a presença de protetores, para os membros superiores e inferiores, acoplados ao computador. Ainda, o uso de botas, luvas, avental e óculos, que permitem o manuseio dos produtos químicos utilizados nas análises de qualidade dos produtos. $\mathrm{O}$ trabalho é de fluxo contínuo e os trabalhadores atuam em jornada de 8 horas, em turnos alternados.

Foi possível identificar no local a presença de cargas físicas, configuradas por temperatura inadequada, derivada da presença de um único aparelho de ar condicionado, precária iluminação, com a metade das lâmpadas disponíveis apagadas. Como cargas químicas, destacamos o odor acentuado, proveniente de produtos químicos utilizados para a realização das análises; como cargas fisiológicas, o trabalho sentado, durante a maior parte do tempo. O modo de realização do trabalho mostra que as atividades desenvolvidas no setor são do tipo leve, porém com predomínio das cargas psicológicas, como a pressão da chefia e o trabalho em turnos. 
Na seqüência, encontra-se o setor de mistura, moinhos e micro-ingredientes. Esse setor pode ser considerado como o início do processo de produção, propriamente dito, funcionando em fluxo contínuo, com 6 funcionários em cada turno. Dois funcionários desempenham atividade de controle de painel, uma vez que a atividade de misturar os ingredientes nos moinhos está automatizada. Entretanto, três outros funcionários desempenham atividade manual de abrir os sacos de matérias-primas, despejar o conteúdo em grandes baldes, pesá-los e alimentar os moinhos. Um funcionário trabalha na parte de micro-ingredientes, manipulando partículas para desenvolver a cor e sabor nos produtos alimentícios; com este manuseio, o trabalhador recebe uma intensa carga das partículas manipuladas, em suas vestimentas e corpo.

Destacamos, como cargas laborais, as físicas: o calor, a eletricidade, alta voltagem e o ruído intenso. Dentre as químicas: poeiras em suspensão, e, principalmente, as psicológicas, uma vez que, além da continuidade do processo de trabalho, ocorre a exigência da atenção e cuidado do trabalhador, pois, a qualquer descuido, o produto poderá não corresponder às condições ideais ou, ainda, ocorrer um acidente grave. Desse ponto de vista, o trabalho pode ser considerado como uma atividade intensa.

Anexa a essa área, encontra-se a sala de congelados, local destinado à guarda de produtos perecíveis, em câmaras frias, que são utilizados na cobertura e recheio dos produtos alimentícios. No local, trabalham três pessoas por turno, cujas atividades consistem em carregar empilhadeiras com produtos perecíveis, transportá-las até os recipientes e, através do controle de painéis, observar o tempo de cozimento dos alimentos que são acrescidos aos produtos elaborados, nas outras fases de produção.

O local de trabalho caracteriza-se pela presença de odores e barulho intensos, por mudanças bruscas de temperatura, o que requer dos trabalhadores o uso do EPI, tais como: protetores auriculares, luvas, botas e capa de borracha. O trabalho é realizado em pé, 
solitariamente, pois as pessoas que lá trabalham, não têm contato com os outros setores da produção. Encontram-se no setor, extintor de incêndio e exaustor de parede, cujo desempenho não é suficiente para renovar o ar, expulsando do local as poeiras e os odores intensos. Por essas características, os trabalhadores têm que utilizar continuamente protetores auriculares; no entanto, encontramos trabalhadores do setor sem esses requisitos.

No setor, encontram-se todos os tipos de cargas laborais, destacando-se, como cargas físicas: o intenso barulho, proveniente dos moinhos e o calor intenso. Como cargas mecânicas, o uso de instrumento cortante, para abrir os sacos de matérias-primas e o uso de carro manual, para o carregamento e deslocamento dos sacos de matérias-primas. Como cargas químicas, destacam-se poeiras e odores provenientes das matérias-primas utilizadas. Como cargas fisiológicas, ergonômicas, movimentos repetitivos e bruscos dos membros superiores para o carregamento e descarregamento de matérias-primas que alimentam os moinhos, e o trabalho em pé dos controladores de painéis. Como cargas psicológicas, a exigência de muita atenção no controle do painel e no uso do computador, para informar às máquinas, os tipos de misturas, em função dos tipos de alimentos a serem produzidos. Chamou-nos a atenção aqui, o trabalho repetitivo, que, apesar do aparente controle, disponibiliza pouca autonomia do trabalhador no processo de trabalho. Pelas características dos trabalhos realizados no setor, entendemos que aí se encontram modos de atividades que se classificam como moderadas e outras, como intensas.

Compondo o processo de produção propriamente dito, encontram-se, na seqüência, as fases de cozimento, secagem e de adição de cobertura dos produtos. Esses procedimentos finais dão palatabilidade; e finalmente, ocorre o resfriamento dos produtos. Essas fases também requerem o trabalho de fluxo contínuo, realizado por 12 trabalhadores, por turno de trabalho. 
Em relação ao modo de ser do trabalho nessa fase, predomina o trabalho automatizado que coexiste com o trabalho manual. Ou melhor, há predominância de trabalho morto, ações repetitivas, em detrimento do trabalho vivo, criativo. Isto significa que os trabalhadores, em sua maioria, são operadores e controladores de painéis. O local caracteriza-se pela presença de um conjunto de cargas laborais, destacando-se o calor, odores, barulho intensos e iluminação inadequada.

Nas observações realizadas, registramos o fato de trabalhadores comerem produtos, em processo de elaboração, e também que o modo de ser do trabalho, nessa fase do processo de produção, caracteriza-se pelo trabalho em pé, pela repetição de movimentos corporais, exigência de muita atenção no controle de painéis, caracterizando o trabalho monótono que, segundo Dejours (1992) pode gerar embotamento psíquico nos trabalhadores. Neste setor,encontram-se atividades que se classificam de moderadas a intensas.

Finalizada a fase de produção alimentícia, segue a de ensaque e armazenamento dos produtos, sendo que, neste momento, encontra-se o maior número de trabalhadores que desempenham as suas atividades em turnos, totalizando 50 trabalhadores por turno.

A forma de realização do trabalho, nesta fase, combina o trabalho automatizado e o manual. Enquanto o primeiro tipo caracteriza-se pelo controle de painéis, quanto ao ensacamento dos produtos, o segundo tipo caracteriza-se pelo recebimento dos produtos ensacados, que, manualmente, são colocados em esteiras que os transportam para um local onde outros trabalhadores, também de forma manual, retiram o produto das esteiras, colocando-os nos palets de madeira, para serem transportados pelas empilhadeiras até o local de armazenamento.

As cargas laborais presentes nessa área de trabalho são o barulho e calor intensos e a possibilidade de acidentes entre os operadores de painéis e de empilhadeiras; entre os trabalhadores manuais, há possibilidade de ocorrerem problemas ósteo-musculares e quedas, 
devido ao chão escorregadio. O modo de realização do trabalho, nessa área, também se caracteriza pelo trabalho em pé, movimentos repetitivos e monótonos, com uso intenso dos membros superiores e movimentos de flexão com a coluna vertebral. O modo de ser do trabalho mostra que as atividades desenvolvidas no setor são do tipo intensas.

O último momento do processo é o de carregamento dos produtos em caminhões transportadores, para serem destinados ao mercado consumidor. Essa fase caracteriza-se pelo trabalho terceirizado, cuja empresa transportadora é responsável pelos trabalhadores que, manualmente, carregam os caminhões.

Em local separado do galpão, onde se concentram todas as fases do processo de produção dos alimentos, encontra-se o setor de mecânica. Nele, atuam 25 trabalhadores que, em turnos de 8 horas de trabalho, são responsáveis pelos consertos da maquinaria e das empilhadeiras. Este setor pode ser considerado nevrálgico para a empresa, pois é ele que garante o fluxo contínuo do processo de produção.

Está presente no setor um conjunto de cargas laborais, destacando-se calor e barulho intensos e vapores, provenientes de produtos químicos que são manuseados; os trabalhadores, também estão sujeitos a ferimentos e esmagamento, principalmente dos membros superiores, em consequiência de as ferramentas que utilizam no conserto dos equipamentos. Outro aspecto, já mencionado, é a pressão da chefia, pois desse setor depende, muitas vezes, o funcionamento adequado de um determinado equipamento. Pelas características dos trabalhos realizados no setor, entendemos que, lá encontram-se atividades que se classificam como moderadas e outras como intensas.

Do lado oposto ao setor de mecânica, em relação ao galpão de produção, encontra-se uma área aberta e coberta, onde funciona o setor de manutenção.

No setor atuam 6 trabalhadores, com jornada diária de 8 horas de trabalho, sob o regime de contrato do trabalho terceirizado. Esse local é inadequado e insalubre, à medida que 
não protege os trabalhadores de intempéries climáticas, caracterizadas pela presença de calor e barulho intensos, vapores provenientes do manuseio de óleo, chumbo, graxa, entre outros. Como a maioria dos trabalhadores nem sempre usa EPI, eles se expõem diariamente a esse conjunto de cargas laborais, adversas à sua saúde. Por essas características, o trabalho mostra que as atividades desenvolvidas no setor são do tipo intensas.

Situado em andar superior, ao lado do setor de manutenção, encontra-se o Almoxarifado, responsável pelo suprimento das mais diversas peças e elementos, necessários aos setores de mecânica e manutenção. Este local também funciona ininterruptamente, caracterizando-se como local que apresenta ventilação inadequada e dispõe de milhares de peças de reposição da maquinaria, o que requer memória e atenção intensas daqueles que respondem pelo Almoxarifado. Aqui, o modo de ser do trabalho mostra que as atividades desenvolvidas no setor são do tipo leve.

O único setor da empresa, diretamente vinculado ao processo de produção, que emprega mão-de-obra feminina é o setor de produtos de higiene pessoal. O modo de ser do trabalho aí realizado congrega atividades, em sua maioria manuais, já que apenas o momento de envazamento de produtos está automatizado. Por exemplo, uma funcionária do setor, manualmente coloca 3 mil etiquetas, por dia, nos produtos. As atividades realizadas expõem as trabalhadoras a um conjunto de cargas laborais, destacando o trabalho em pé ou sentado, vapores e odores intensos, provenientes dos produtos químicos usados na elaboração dos produtos de higiene pessoal, e, ainda, a realização de um trabalho repetitivo, sem criatividade, o que caracteriza dessa maneira, as atividades como moderadas.

A empresa conta ainda com um Centro de Pesquisa, onde trabalham, em jornada diária de 8 horas, 3 trabalhadores que são responsáveis pela realização de teste de produtos produzidos pela empresa, visando principalmente aferir o grau de aceitação e de palatabilidade dos consumidores, bem como proceder à realização de testes em produtos, a 
partir de queixas dos consumidores. As cargas laborais presentes são do tipo fisiológicas, como a posição em pé, e psicológicas, exigindo atenção de quem trabalha no setor, configurando, portanto, atividades que podem ser caracterizadas como leves.

Conforme referência inicial, a empresa é de médio porte. Considerando os diferentes processos de trabalho, entendemos que, na sua maioria, as atividades desenvolvidas classificam-se como trabalho intenso.

\subsection{A organização da CIPA e do SESMT}

Nesse quadro, ao pretendermos estudar a educação em saúde na CIPA em uma empresa, descobrimos que esta se encontra constituída desde 1977, apesar da CIPA ter sido regulamentada em 1945, com a Consolidação das Leis do Trabalho (CLT). Nesse momento, em relação à sua organização, a CIPA conta com 10 integrantes efetivos, na proporção de 4

para seis, entre indivíduos eleitos e indicados, mostrando uma desproporção já na sua organização.

Na nova redação da Portaria ${ }^{\circ} 8$ de 23/02/99 que, altera a NR-5, a empresa teria até 23/05/99, para se adequar às novas exigências dessa portaria; logo, extinto o prazo, estamos em 2004, a empresa deve se encontrar enquadrada no regulamento. Nesse aspecto, os membros deveriam ser substituídos com rapidez, para que a CIPA não venha a sofrer as consequiências por falta de integrantes, apesar de também ser previsto o caso de mudança na empresa. Uma outra consideração é que o empregador deve garantir ainda que seus indicados, titulares e suplentes, tenham representação necessária, para a discussão e encaminhamento das soluções de questões de saúde e segurança, analisados na CIPA.

A CIPA tem, como vimos anteriormente, o objetivo de prevenção de acidentes e doenças decorrentes do trabalho, de modo a tornar compatível, permanentemente, o trabalho 
com a preservação da vida e a promoção da saúde do trabalhador; cujas atribuições também já foram abordadas. Assim, entendemos que a CIPA reúne um grupo de empregados em evidência, que são mantidos por força de lei para as empresas, exercendo papel fundamental na prevenção dos acidentes de trabalho.

Em relação ao SESMT, que foi criado em 1978, a empresa era composta por um engenheiro do trabalho, um técnico de segurança, um auxiliar de enfermagem e uma médica do trabalho, que assumem, diretamente, a análise e compreensão dos processos de trabalho da empresa, destacando-se o PCMSO e o PPRA, elaborados pelo SESMT. Em 1994, o MTb, através da Norma Regulamentadora 7 (NR-7), que institui o Programa de Controle Médico de Saúde Ocupacional (PCMSO), e a Norma Regulamentadora 9 (NR-9), que cria o Programa de Prevenção de Riscos Ambientais (PPRA), integrando esses programas, como parte das atividades dos SESMT's, o que fragmenta mais ainda as atividades institucionais do aparelho de Estado.

Porém, assinalamos a insuficiência do SESMT, para, garantir a saúde e segurança da empresa, pois, se a saúde é entendida como qualidade de vida e processo social, seus instrumentos de construção coletiva, exigem a co-responsabilidade do empregador e do trabalhador, como sujeitos necessários à incorporação dessas práticas legais. Nesse aspecto, entendemos que o estreitamento da relação capital trabalho é importante na direção de superação das contradições.

O PCMSO e o PPRA, prescritos legalmente, existem nessa empresa: a NR-7 e a NR-9 estavam sendo cumpridas, no período da pesquisa: os exames eram realizados e os Equipamentos de Proteção Individual (EPI) eram distribuídos, conforme prevê a legislação concernente ao tema.

As informações constantes no PCMSO, bem como o quadro da época, no que diz respeito aos acidentes ocorridos na empresa, obtidos por meio das atas das reuniões dessa 
CIPA, podem nos dar informações importantes sobre o processo saúde-doença. Reafirmamos que tanto as doenças, quanto os acidentes do trabalho trazem sérias consequiências à vida do trabalhador, isto é, existe uma forte relação entre saúde e trabalho; entre o modo de produção capitalista e o adoecer. Daí, perguntarmos: o que torna o trabalho humano, tantas e continuadas vezes, nocivo, arriscado, perigoso? Sabe-se que o trabalho em si não é nocivo, arriscado e nem perigoso. O que o torna assim é a forma de sua organização pelas empresas, provocando fadiga, exaustão, doenças e acidentes do trabalho. Porém, entendemos que a relação capital-trabalho também fornece aos trabalhadores instrumentos de luta contra o poder dominante; entre outros, citamos a CIPA, como um instrumento legal importante, na luta contra as condições inadequadas da organização do trabalho.

Um exemplo disso aparece no gráfico abaixo, que se relaciona aos acidentes registrados, ocorridos no período de 1997 a 2002, mostrando-nos uma forte tendência à diminuição, após a criação e inserção da CIPA na empresa, entre outros motivos.

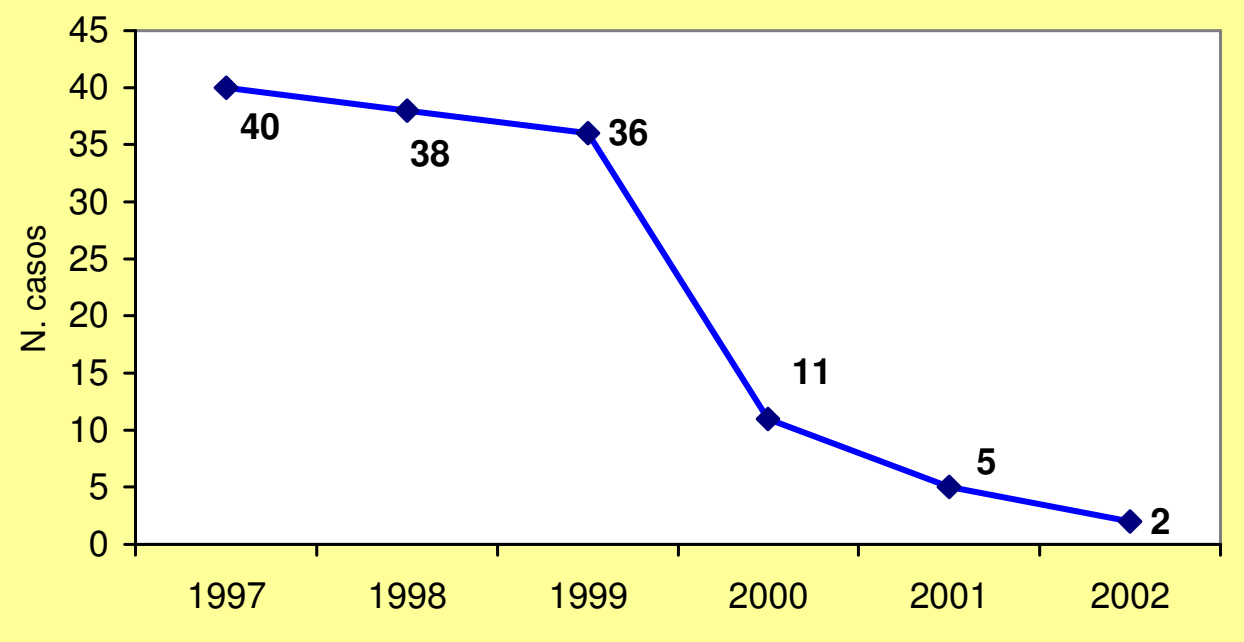

Fonte: Estatísticas da CIPA (atas das reuniões).

Gráfico 6 . Distribuição de acidentes de trabalho, com afastamento de 1997 a 2002, na empresa estudada. 
Dos documentos, por nós recolhidos e analisados, as atas e os questionários merecem um destaque, pois neles estão contidas as informações que foram consideramos para a análise que segue. Essa CIPA começou a ter reuniões periódicas com atas, a partir do ano de 2000, pois, anteriormente as reuniões não eram devidamente registradas.

As categorias do estudo sobre o processo de educação em saúde do trabalhador, em uma empresa de Ribeirão Preto, SP, obtidas no percurso metodológico já descrito, foram as seguintes: a CIPA, segundo os "cipeiros"; a educação em saúde do trabalhador na CIPA, na realidade da empresa e, a relação educação e trabalho na empresa, sendo que estas foram divididas em subcategorias (QUADRO 3).

\begin{tabular}{|c|c|}
\hline CATEGORIAS & SUBCATEGORIAS \\
\hline 1. A CIPA SEGUNDO OS CIPEIROS & $\begin{array}{l}\text { 1.1. AS RAZÕES PARA ESTAR NA CIPA, E PARTICIPAÇÃO } \\
\text { SEGUNDO OS CIPEIROS } \\
\text { 1.2. CONCEITO E AS ATRIBUIÇÕES DA CIPA, SEGUNDO OS } \\
\text { CIPEIROS }\end{array}$ \\
\hline 2.A EDUCAÇÃO EM SAÚDE DO TRABALHADOR NA CIPA & $\begin{array}{l}\text { 2.1.TEMAS ABORDADOS NAS REUNIÕES DE CIPA PARA } \\
\text { DESENVOLVIMENTO EM ATIVIDADES EDUCATIVAS } \\
\text { 2.2. TEMA-A PREVENÇÃO DE ACIDENTES } \\
\text { 2.3.OS MEIOS UTILIZADOS EM EDUCAÇÃO EM SAÚDE, } \\
\text { SEGUNDO OS CIPEIROS } \\
\text { 2.4.PRÁTICAS/ATIVIDADES DE EDUCAÇÃO FORMAL } \\
\text { 2.5.ATIVIDADES DE EDUCAÇÃO INFORMAL } \\
\text { 2.6 AS SIPATS } \\
\text { 2.7.PROBLEMAS E SOLUÇÕES IDENTIFICADOS NA PRÁTICA } \\
\text { EDUCATIVA }\end{array}$ \\
\hline 3, A RELAÇÃO EDUCAÇÃO TRABALHO NESSA EMPRESA & $\begin{array}{l}\text { 3.1. O AMBIENTE DE TRABALHO } \\
\text { 3.2.PROBLEMAS E SOLUÇÕES, IDENTIFICADOS NO } \\
\text { COTIDIANO DA FÁBRICA } \\
\text { 3.3 O SESMT EM SUA ATIVIDADE EDUCATIVA }\end{array}$ \\
\hline
\end{tabular}

Quadro 3 as categorias e as subcategorias do estudo 


\subsection{A CIPA}

\subsubsection{A CIPA segundo os cipeiros}

\subsubsection{As razões para estar na CIPA, e a participação segundo os "cipeiros"}

Do conjunto das respostas obtidas e das atas lidas, bem como da observação e diário de campo da pesquisadora, obtivemos, em relação às razões e ao interesse em participar da CIPA, que as preocupações dos trabalhadores estão mais voltadas para o coletivo do que para o individual, o que demonstra envolvimento com a CIPA, merecendo ressaltar que apenas um "cipeiro" demonstrou interesse particular em participar da CIPA. Para efeito de apresentação dos dados, designamos todos os que responderam ao questionário por números, preservandoos, como podemos visualizar abaixo.

"Meu interesse vem em primeiro lugar, pela minha saúde e proteção dentro da empresa, e agir de modo a garantir a segurança e informações de meus companheiros de trabalho, à empresa e também a seus funcionários" (cipeiro 6).

No entanto, encontramos motivos de desenvolvimento pessoal e profissional com compromissados entre as respostas. Quando as pessoas se mobilizam por razões, mais grupo e menos ego, os resultados das atividades variam, não apenas pelo êxito (ou não) alcançado, mas, principalmente, pela forma como se processou a construção saudável de qualquer execução de trabalho.

Bordenave (1994) nos revela que a participação é inerente à natureza social do homem, tendo acompanhado sua evolução, ao longo da história. E ela tem duas bases complementares, uma afetiva, em que se participa, pois há prazer, em fazer as coisas com os outros; uma base instrumental, em que participamos, porque realizar coisas com os outros é mais eficaz e eficiente do que fazer sozinho. Então, em relação aos nossos dados, encontramos as duas bases, afetiva e instrumental (ANEXO I, QUADRO 1.1.). 
“Ajudar a melhorar as condições de trabalho" (cipeiro 4).

"Aprender e passar algum conhecimento adquirido durante minha gestão" (cipeiro 7).

Esse autor menciona ainda que a participação pode ser: de fato, para subsistência ou manifestações culturais; espontânea, sem organização estável ou propósitos claros e definidos; imposta, em que o indivíduo é obrigado a fazer parte de grupos; voluntária, se o grupo for criado pelos próprios indivíduos, que fazem suas regras; provocada, quando há posturas organizados, institucionalizados, por exemplo, a educação em saúde; finalmente, a participação concedida, em que há planejamento participativo. No caso em estudo, ela incluise dentro da participação provocada, visto que a CIPA é criada por determinação legal, tendo entre suas atribuições, as atividades educativas na empresa.

Então, no tocante à sua participação, o cipeiro 1 nos revela fatos importantes,

"Um pouco tímida! Os participantes mais próximos dos níveis operacionais ainda se sentem constrangidos de se afastarem de seus postos de trabalho para participar das reuniões. Todavia, em geral, mostram-se motivados"..."Devido às grandes mudanças atuais na empresa, a participação da CIPA está sendo um pouco prejudicada“ (cipeiro 1).

Verificamos, primeiramente, que, apesar de considerarem como boa a sua participação na CIPA, os "cipeiros" não conseguem se ver como detentor de poder que lhe é conferido por lei; uma vez que a Portaria $n^{\circ} 8$, diz em seu texto, item 5.24: “As reuniões da CIPA serão realizadas durante o expediente normal da empresa e em local apropriado" (BRASIL,1999).

Dizem acreditar que o motivo está nas dificuldades de a empresa em se reestruturar, devido ao fato de ter havido mudanças na reorganização gerencial, conforme já explicitado na parte metodológica, ocultando o fato da não liberação dos funcionários para reuniões, cursos e 
treinamentos; daí, a baixa frequiência e pouca participação nas reuniões, bem como a falta de informações, e também a falta de envolvimento das chefias mediatas, levando, inclusive, ao descrédito nas ações da CIPA, como pode ser visto no QUADRO 2.7., (ANEXO I).

"A CIPA deveria receber mais atenção e deveria ser tratada com mais apoio e seriedade pelas chefias" (cipeiro3).

Trabalhador em reunião opinou dizendo que é importante a presença do superior imediato, durante as reuniões/diálogos (ATA DE AGOSTO DE 2002).

A empresa e sua diretoria não privilegiam as ações da CIPA e as chefias estão mais preocupadas com a produção (Observação de 1309-02).

Acreditamos que a participação real deveria ser apoiada pelas chefias, desde a liberação para reuniões, cursos e treinamentos, até a facilidade de aproximação dos "cipeiros" junto dos trabalhadores; porém, nessa empresa estudada, não foi isto que ocorreu. Esse fato pode significar também uma forma de controle por parte da empresa, pois apesar da CIPA existir formalmente, os funcionários não são incentivados e motivados à sua adesão. Como podem eles, atuar da forma como a lei prevê? Então, essas ocorrências devem ter contribuído, ao nosso ver, para a variedade das respostas obtidas.

Bordenave (1994) revela que é questão chave na participação de uma organização, o grau de controle exercido pelos membros sobre essa organização, e quão importantes são as decisões nas quais se pode participar. Daí, depreende-se que a participação pode ser simbólica ou real: na primeira os membros de um grupo têm influência mínima nas decisões e operações; na real, entretanto, os membros influenciam todos os processos da vida institucional. Por essa definição, entendemos que essa CIPA encontra-se em nível de participação simbólica, pois seus membros não detêm o controle das decisões e operações da 
empresa. E ainda, ao verificarmos o grau de realização e de satisfação, em relação às suas atividades na CIPA, todos responderam que não têm feito o que desejavam, mostrando que os dirigentes da empresa precisam rever o compromisso que têm com a CIPA, isto é, a real prevenção de acidentes, via educação em saúde do trabalhador.

Esse autor afirma, ainda, que a participação tem alguns princípios, entre os quais destacamos: é um direito de todos, é um processo de desenvolvimento de consciência crítica e de aquisição de poder, pode resolver conflitos, mas também pode gerá-los; finalmente, é algo que se aprende e aperfeiçoa (Bordenave, 1994, p.78)

Ninguém nasce sabendo participar, mas, como se trata de uma necessidade natural, a habilidade de participar cresce rapidamente quando existem oportunidades de praticá-la. Com a prática e a autocrítica, a participação vai se aperfeiçoando, passando de uma etapa inicial mais diretiva a uma etapa superior de maior flexibilidade e autocontrole, até culminar na autogestão.

Portanto, acreditamos que essa CIPA poderá amadurecer nesse sentido, o de tornar-se mais participativa e, assim, adquirir um controle maior, em relação ao processo educativo na empresa.

\subsubsection{O conceito e as atribuições da CIPA, segundo os "cipeiros"}

Por acreditarmos que o conhecimento conduz a uma ação e que a eficácia deste processo depende da participação ativa dos envolvidos, na descoberta de suas necessidades, na organização adequada dos meios, para que se modifiquem as situações consideradas insatisfatórias, logo, o desconhecimento do conceito de CIPA poderia levar-nos a pensar que os "cipeiros" não têm a capacidade potencial de identificar suas necessidades, formular seus problemas e organizar suas ações, como pode ser considerado a seguir. 
"Comissão interna de Prevenção de Acidentes, constitui por representantes dos empregados e do empregador" (cipeiro 1).

Porém, relativizando, os (QUADROS 2.2.; 2.3., ANEXO I) revela-se um compromisso com a CIPA e suas atividades de prevenção e promoção da saúde, como prevê a NR-5.

No entanto, não basta o desejo de participação, pois a participação real precisa de certos processos, por meio dos quais o grupo realiza sua ação transformadora sobre o ambiente e sobre os próprios membros, que são: o conhecimento, a organização e a comunicação, conforme nos lembra Bordenave (1994).

Ora, os "cipeiros" têm funções específicas na prevenção de acidentes, mesmo que sejam, no dia-a-dia, trabalhadores comuns. Eles devem ser treinados antes de assumirem o cargo de membros da Comissão, conforme prevê a legislação. As minhas observações mostram que todos foram treinados, segundo as exigências da NR-5; e, apesar disso, as respostas, acerca das atribuições legais, são pouco expressivas em conteúdos, levando a crer que o treinamento exigido para os "cipeiros" (20 horas), que tem um currículo único em qualquer caso, deveria ser direcionado aos riscos específicos da empresa. O seu conteúdo não parece suficiente, com o objetivo de capacitar os membros da CIPA oferecendo a devida orientação aos trabalhadores, devido à variedade das situações de agravos que podem ocorrer nos ambientes de trabalho; assim, não têm a habilitação suficiente e necessária para a condução de uma prevenção efetiva.

Em relação às atribuições da CIPA, destacamos as respostas do "cipeiro" (3) (QUADRO 1.2., ANEXO I),

"A CIPA tem, como prerrogativas, promover a divulgação da prevenção de acidente, utilizando, para isso, treinamentos e atividades 
dinâmicas, se reúne para discutir todos os assuntos relativos às ocorrências de acidentes e apontar soluções, para se evitar que tais acidentes se repitam; também é o elo de comunicação entre os níveis operacionais e a alta administração da empresa, para promover a segurança, higiene e organização dos ambientes de trabalho" (cipeiro $3)$.

A resposta do "cipeiro" (5), está marcada pela crença de que a CIPA, por meio de suas reuniões, tem poder de transformação,

"Ajudar a melhorar as condições de trabalho com reuniões" (5).

Consideramos importante a clareza sobre a compreensão de nossa ação, que envolve uma teoria, quer tenhamos consciência dela ou não. Então, se a teoria e a prática estabelecem uma relação de reciprocidade, a reflexão sobre a ação evidencia a teoria e vice-versa. Ou seja, nossa prática revela-se com um novo significado, ao ser iluminada por uma teoria, da qual o sujeito que atua se apropria com lucidez. Com isso, queremos mostrar a relação, entre teoria e prática, ressaltando o conhecimento, como forma de obtenção de elementos que podem mudar nossas ações (FREIRE,1996).

Por esse motivo, entendemos que a educação, para ser efetiva, deve ser consciente, não apenas transferência de conhecimentos. Freire coloca que o homem, como um ser histórico, inserido num permanente movimento de procura, faz e refaz constantemente o seu saber, na relação dialética com a realidade, e aí a educação pode ser libertadora. Em suas próprias palavras, Freire (1997, p. 47) "[...] ensinar não é transferir conhecimento, mas criar as possibilidades para a sua própria produção ou sua construção".

O homem experimenta, enquanto ser cultural, histórico, social, pensante, comunicante, inacabado e condicionado à consciência do inacabamento, e daí pode e deve explorar várias possibilidades, desde que éticas, para a transformação das condições materiais de sua existência. Freire (1996) ressalta que é a relação, entre a dificuldade e a possibilidade de 
mudar o mundo, que coloca a questão da importância do papel da consciência, da ética, da educação: "Gosto de ser gente, porque a História em que me faço com os outros e de cuja feitura tomo parte, é um tempo de possibilidades e não de determinismo. Daí que insista tanto na problematização do futuro e recuse sua inexorabilidade" (FREIRE,1996, p. 53).

Nesse sentido, ao abordarmos as transformações nos ambientes de trabalho, talvez a questão central seja a de reconhecer que a luta é uma categoria histórica, e, assim, possamos reinventar a forma também histórica de lutar.

As diretrizes gerais e princípios norteadores para a revisão da NR-5, em 1999, foram: criar condições que facilitassem a negociação bipartite (trabalhadores e empregadores) nos locais de trabalho, em relação ao campo da saúde e segurança no trabalho; permitir que itens da norma pudessem ser alterados, dentro dos limites previstos no capítulo V da CLT, para adequação de particularidades regionais e setoriais; fornecer meios que fortalecessem a legitimidade do processo eleitoral da CIPA; criar mecanismos de ampliação da democracia nas discussões, acerca dos acidentes e doenças do trabalho, visando à sua redução; fornecer mecanismos que assegurassem um processo de treinamento, em acidentes e doenças do trabalho, mais democrático, eficiente e adequado às condições de cada empresa; definir as responsabilidades dos contratados e dos contratantes, no que diz respeito aos acidentes e doenças do trabalho; alterar o critério grau de risco, para atividades econômicas, no dimensionamento da CIPA; reduzir as obrigações burocráticas e cartoriais das empresas junto dos órgãos do Ministério do Trabalho e Emprego (BONCIANI, 1999).

Embora se tenha tentado uma NR mais democrática, estabelecendo o direito à CIPA de participação de reuniões promovidas pelo empregador, acesso às CAT's, e paralisação da máquina, caso houvesse suspeita de risco grave e iminente. Ao nosso modo de ver, essa reformulação não mudou a questão central, que é a indicação do presidente da CIPA pelo empregador, inclusive com direito a ser indicado novamente. Esse fato limita a ação da CIPA, 
pois, ao estar atrelada a alguma pessoa ou estrutura, acaba não cumprindo seu papel de prevenção de acidentes na sua totalidade. Acreditamos que este fato deva ser também repensado. E assim, a CIPA, como instância legalmente reconhecida na NR-5, pode ser um espaço de oposição e um meio de conscientização do trabalhador, acerca de seus questionamentos.

\subsubsection{A CIPA na realidade da empresa}

\subsubsection{Temas abordados nas reuniões de CIPA para desenvolvimento em atividades} educativas

Se falarmos de uma instituição ou instância composta de indivíduos, desprezarmos o fator sempre novo e que foge ao controle, a nossa individualidade, estaríamos incorrendo em semelhante erro dos que tratam a cultura empresarial ou movimento social, como um determinado padrão cristalizado, sem interferências. Portanto, ao analisarmos a CIPA e seus meios educativos, devemos também considerar a subjetividade, bem como a satisfação da coletividade que ocorre, por meio da produção de obras. Nesse sentido, será que os temas ou assuntos abordados nas reuniões, foram apropriados para essa CIPA em particular, (QUADRO 2.1., ANEXO I), no sentido de alcance do objetivo, prevenção de acidentes, em seu contexto concreto de trabalho?

Os trabalhos a serem desenvolvidos, neste mês são: Grupo de Informação, Alcoolismo (ATA DE MARÇO DE 2000).

Foram discutidos, os temas e assuntos da SIPAT-2000, como o Alcoolismo, Meio Ambiente, Desperdício de Água e teatro, sobre Prevenção de Acidentes no Trabalho (ATA DE OUTUBRO DE 2000). 
Nesta reunião foi conversado sobre o hábito de fumar, entre os trabalhadores (Observação de 13-09-02).

Entendemos que assuntos como o alcoolismo e tabagismo revelam uma preocupação com a saúde individual do trabalhador e suas conseqüências sociais; o meio ambiente e desperdício de água estão menos inseridos em preocupação com o meio que nos cerca, e mais no patrimônio da empresa, como pude constatar, por meio de minhas observações de campo.

No entanto, apesar de importantes para a saúde como um todo, os assuntos abordados nas reuniões dessa CIPA denotam um desconhecimento dos problemas específicos da saúde do trabalhador, ou um equívoco por parte dos "cipeiros", pois apesar do tema mais freqüente ter sido à prevenção de acidentes, seguido da preocupação com a integridade física dos funcionários e empresa, nesta CIPA, temas de relevância para a área saúde e trabalho não foram abordados.

Segundo Buss (1999), as ações de educação em saúde, componente fundamental da promoção da saúde, já tem uma história em nosso país: desde programas individuais até programas dirigidos a coletividades. No caso dos trabalhadores, podem-se abordar temas sobre o meio físico, condições de saneamento industrial, vigilância do ambiente, vigilância da organização do trabalho; enfim, vigilância da saúde no contexto das atividades produtivas.

Sabemos que a área saúde do trabalhador, onde se inserem essas ações de educação em saúde é uma área complexa, pela diversidade dos processos de trabalho, pelas novas tecnologias, pelos modos de realização do trabalho e pelos próprios trabalhadores. Instituí-se no Brasil, na década de 1980, tendo, como características mais importantes, um novo olhar na saúde e segurança no trabalho, denúncia ao sistema de saúde, e ênfase a novas práticas sindicais e reformulação do trabalho das CIPA's.

Por exemplo, no tocante às análises das políticas de saúde do trabalhador, na proposição da epidemiologia social, é importante estudar o contexto bio-psicosocial do 
indivíduo e da coletividade, pois o processo saúde-doença é compreendido, a partir de um conjunto de determinantes históricos, e não no plano individual das causas biológicas. Isso não ocorreu nessa CIPA, na própria proposição da NR-5, onde há o privilégio de políticas pontuais e de cunho assistencialista, como os programas de controle da saúde do trabalhador, por meio de exames admissionais, periódicos e demissionais, os de controle de riscos nos ambientes de trabalho, mas sem a intervenção nos modos de realização dos processos de trabalho, na redução das cargas laborais específicas às atividades desenvolvidas nas empresas.

Além disto, o perfil epidemiológico em saúde do trabalhador, aponta a alta incidência de acidentes e doenças do trabalho, com tendência ascendente, com baixo número de casos notificados e registrados; exposições profissionais a altas concentrações de agentes tóxicos e poluentes, com efeitos agudos e de curta latência; presença de outras doenças relacionadas ao trabalho, porém não reconhecidas, tanto no aspecto legal, quanto epidemiológico; perfil de morbidade geral, caracterizada pelo predomínio das doenças infecciosas e parasitárias, desnutrição e doenças carenciais (LINO e DIAS, 1995). O que se verifica nessa empresa, além dos acidentes do trabalho, e, talvez, mesmo como causa deles, a presença de várias cargas laborais. Isso aparece na observação dos ambientes de trabalho, desde cargas físicas, ruído, calor, umidade; cargas químicas, poeiras; mecânicas, excesso de peso, até as fisiológicas, trabalhos repetitivos, trabalhos em turnos, e psicológicas como a pressão das chefias e o stress.Ora, tais temas não apareceram nas atas das reuniões da CIPA, examinadas neste trabalho.

Laurell e Noriega (1989) destacam que, dentre as contribuições relativas a área saúde do trabalhador, podemos citar a inclusão dos trabalhadores, como sujeitos das avaliações dos perigos presentes em seus trabalhos, incorporação de análises histórico-econômicas, como também novas categorias analíticas, cargas de trabalho e processos de desgaste, que possibilitam extrair elementos determinantes do nexo biopsíquico e consignar as 
transformações negativas, originadas pela interação dinâmica das cargas, nos diversos processos biopsíquicos humanos.

Mendes e Casagrande (1998, p. 11), ao discorrerem sobre os trabalhadores e a educação em saúde, afirmam que

Para conseguir, porém, junto aos indivíduos o aproveitamento de suas capacidades e algum grau de envolvimento em relação ao que vão aprender, é preciso que, previamente ao início de processos desse tipo, se saiba quanto as pessoas conhecem e o que conhecem. E mais, é preciso que se saiba que percepção os indivíduos têm relativamente ao problema em questão, para que, sendo ajudados mediante a ação educativa, cheguem à percepção verdadeira de sua realidade.

Então, as autoras apontam um caminho no qual o conhecimento das experiências prévias do aprendiz é primordial, à tentativa de empreendimento de um processo educativo; no caso, em estudo, a observação mostrou que o conhecimento dos "cipeiros" sobre a saúde do trabalhador limita-se às doenças da população em geral.

Outro fator relevante foi o fato de as discussões, muitas vezes, atenuarem conflitos, em vez de discuti-los, em profundidade necessária à problematização geradora de consciência. Faltou provocar uma mudança da cultura organizacional, e, assim, romper com o tradicional papel da CIPA, como instrumento de ação gerencial no controle do trabalho e dos trabalhadores. Se compreendemos como movimento contra-hegemônico, aquele que se constrói em favor dos interesses dos trabalhadores e não do capital, toda a complexa rede de conhecimentos e habilidades, necessárias à prática educacional, visando à mudança de paradigmas, será considerada como conscientizadora por nós. Conseqüentemente, temos que os assuntos tratados pela CIPA na empresa estudada, não tiveram um aprofundamento necessário, para que houvesse a conscientização dos trabalhadores.

Mendes e Casagrande (1998, p. 11) afirmam: 
Considerando a educação como forma para despertar a consciência preventiva em relação aos infortúnios possíveis no trabalho, educação esta que visa o conhecimento, por parte do trabalhador, dos riscos aos quais se expõe e sua motivação para evitar estes riscos, a própria legislação insiste no caráter educativo que deve ser dado às campanhas realizadas nos ambientes de trabalho.

Assim, a educação pode levar à consciência, à liberdade, pela potencialização de novos espaços de discussão nos ambientes de trabalho, pois um dos objetivos do conhecimento sobre a relação saúde-doença-trabalho é a de contribuição para uma emancipação política dos sujeitos, envolvidos nesse processo. Portanto, a ação que transforma a realidade vem da reflexão e isto só ocorre através do pensamento articulado à prática. Nessa direção, a comunicação assume um papel muito importante, e Freire (1989b, p. 69) salienta isso, quando nos lembra que: "a educação é comunicação, é diálogo, na medida em que não é transferência de saber, mas um encontro de sujeitos interlocutores que buscam a significação dos significados".

Porém, não basta saber o que é a educação, pois entendemos que não basta apenas mudar o nível de consciência da situação; é preciso modificar também as condições materiais para a concretização da ação. Dessa maneira, devemos rever a prática pedagógica da educação em saúde do trabalhador nos ambientes de trabalho. Então, ao sabermos que a prática educativa, é um processo contínuo, uma fonte de transformação, será preciso agora analisar se estas discussões (temas ou assuntos) levaram realmente a um aprofundamento das reais causas dos eventos ocorridos, no caso os acidentes do trabalho, pois, como citamos anteriormente, na empresa estudada, o tema mais freqüente foi a prevenção de acidentes, (QUADRO 2.2., ANEXO I).

\subsubsection{Tema - A prevenção de acidentes}


Primeiramente, em nível epidemiológico, relacionado aos acidentes do trabalho, é relevante reafirmarmos que as estatísticas oficiais não são confiáveis, em função da subnotificação e das políticas que norteiam o tratamento dado aos acidentes do trabalho, conforme já abordado anteriormente, razões suficientes, para que os acidentes sejam tratados como são. Aliados a isso, ainda temos o desconhecimento, por parte dos profissionais de saúde que lidam diretamente com a questão, desde médicos, engenheiros de segurança, técnicos de segurança, pessoal de recursos humanos, vigilância sanitária, assim como os trabalhadores e os "cipeiros", que, embora inseridos no contexto fabril, distanciam-se da realidade que os cerca. Este último fato contribui para que se discutam, na CIPA, os acidentes de forma desvinculada e descompromissada com a realidade brasileira.

Binder e Almeida (2003) trazem alguns estudos, realizados por meio da CAT, que tratam dessa questão, conforme já revelado anteriormente. Marcellino (1999) revela o despreparo dos profissionais que lidam com esse instrumento de notificação, o qual dificulta a implementação de um sistema de informação em saúde do trabalhador.

Possas (1987, p.47) afirma que:

Fatores como os baixos salários, a duração excessiva das jornadas de trabalho, a prática das horas extras e as precárias condições de segurança oferecidas pelos ambientes de trabalho, são alinhados com a política governamental dirigida ao setor durante as duas últimas décadas, e apontados como responsáveis por uma situação que gerou acentuada omissão na comunicação dos eventos acidentários, transformando as estatísticas oficiais de acidentes, doenças e óbitos associados ao trabalho em dados pouco confiáveis.

Outra questão, relacionada a isso, ainda, é a ineficiência das Delegacias Regionais do Trabalho (DRT's), para atuar nos ambientes de trabalho, quando se detectam anormalidades nesse campo. Todas essas questões são complexas, porém fundamentais, para serem entendidas e analisadas, ao pretendermos entender as políticas do Estado na questão dos 
acidentes do trabalho e benefícios trabalhistas, bem como a crescente tentativa de implementar uma política neoliberal que vem sendo adotada pelo governo nas ultimas décadas; assim, também entendermos o porquê da ocultação que levam ao desconhecimento das reais causas desses acidentes.

No caso da empresa, em estudo, apesar dos "cipeiros" terem discutido acidentes provocados por caminhões, empilhadeiras, altura, eletricidade e temperatura, visando à sua prevenção, não houve o aprofundamento necessário, para que se pudessem desvendar as reais causas dos acidentes, quais sejam: os agravos a que estão submetidos os trabalhadores, os instrumentos e meios de trabalho e a sua conseqüente organização. Exceção seja feita a duas atas, (QUADRO 2.2., ANEXO I), em que o nível de discussão do tema "acidentes do trabalho" deu-se de forma mais crítica:

Foi discutido o horário de trabalho adotado por uma equipe da empresa e os riscos de acidentes ocasionados pelo seu excesso (ATA DE AGOSTO DE 2000).

Durante a reunião, o técnico e o auxiliar de enfermagem da unidade alertaram sobre a necessidade dos colaboradores realizarem $\mathrm{o}$ revezamento de funções em sua área de atuação, a fim de se evitar lesões por esforço repetitivo (ATA DE ABRIL DE 2002).

O segundo ponto que merece a nossa atenção é o próprio acidentado. Um estudo realizado por Cohn et al. (1985) revela que, se o acidente é leve, o acidentado nem se apresenta, só o fazendo nos casos mais graves que resultam em incapacidade permanente ou invalidez. Isso ocorre, por receio da estigmatização ou dispensa do trabalho. Sabe-se que muitas vítimas de acidentes sofrem, temporária ou permanentemente, redução de vencimentos que obriga a família a baixar repentinamente o padrão de vida, realizar cortes no orçamento doméstico, privar-se de coisas até então usuais, fatos que ferem profundamente a felicidade de indivíduos e das famílias. Apesar de a justiça que se pretende imprimir, com o pagamento de 
indenizações às vítimas ou a seus familiares, o valor indenizatório jamais compensa os danos físicos ou funcionais das vítimas, muito menos os reparam.

Zócchio (1980) afirma que a vítima da incapacidade parcial, o mutilado, embora voltando a trabalhar, poderá sentir-se inferiorizado diante dos demais, ou ser piedosamente aceito pela empresa tornando-se pouco útil para o trabalho. Isso ocorre, quando não recebe o apoio moral necessário após o acidente, ou não lhe é propiciada uma reintegração psicológica, adequada ao trabalho; em casos de incapacidade parcial permanente grave, o acidentado nem sempre adquire, por si só, condições psicológicas de retornar ao trabalho, isento da preocupação de passar a ser objeto de curiosidade, de ficar marginalizado no trabalho ou mesmo de perder o emprego.

E infelizmente, é isso que, vemos ocorrer nas empresas: sem o devido e justo apoio, o acidentado fica desamparado, isto é, além de ter um sofrimento físico e financeiro, muitas vezes é visto como culpado de seu próprio infortúnio, negando-lhes a assistência e a recuperação da dignidade, pois não se discutem as condições de trabalho que levaram à ocorrência do acidente.

Um fato ocorrido, durante uma reunião da CIPA, chamou-nos a atenção, quando o técnico de segurança do trabalho, deu abertura à reunião, comentando um acidente de funcionário da empresa, (ANEXO D).

Houve comentários sobre o acidente ocorrido, chegando-se à conclusão de que foi provocado devido à imprudência do próprio funcionário...Foi observado que o funcionário acidentado poderia ser convidado a participar da próxima reunião da CIPA, para explicar aos presentes, como o acidente ocorreu (ATA DE DEZEMBRO DE 2001).

"Os problemas são os de rotina, manutenção de locais limpos, às vezes um acidente de trabalho, por falta de atenção: mas, enfim, todos unidos conseguiremos alcançar nossos objetivos e os objetivos da empresa" (cipeiro 7). 
A prevenção dos acidentes assume nesse lugar, um caráter punitivo, que culpa o trabalhador. Nota-se que, a teoria da culpabilidade do empregado, em relação ao acidente, parece ter estado presente, pois é aquela em que a culpa do acidente recai sempre no trabalhador.

Cohn et al. (1985) utilizam a expressão "produção de consciência culposa", para designar a relação entre a divulgação oficial, patronal, abordada por diferentes autores, da idéia de que os acidentes são causados por atos inseguros ou propensão ao acidente. Isso leva à elaboração de conclusões, definindo o responsável pelo acidente. Para exemplificar essa "produção de consciência culposa" na literatura, surgem falas como: "aquilo que o trabalhador faz, sem observar certas regras de segurança"; ou adjetivos: "o desatento", "o brincalhão" e "o caso do desleixado", "o caso do machão". Essa concepção tendenciosa e unicausal, a do indivíduo como peça única responsável pelo acidente, dificulta a compreensão acerca das causas reais do acidente do trabalho, bem como as ações preventivas ou de promoção à saúde da coletividade dos trabalhadores, mais uma atribuição da CIPA.

Zócchio (1980) reafirma que os acidentes do trabalho sempre se constituíram em problemas sociais. Mesmo nos períodos de escravatura ou de servidão remunerada, quando não se ligava para o acidente e os acidentados eram simplesmente tidos como um subproduto do trabalho, os problemas sociais, decorrentes dos acidentes, existiam. Apenas não eram reconhecidos como o são hoje, lembrando que a primeira lei acidentária data de 1919. Os problemas sociais que contribuem para ocorrência de acidentes, assim como que são ocasionados por eles, têm sido objeto de muitos estudos e recomendações. Isso acontece em função da extensão que assumem no âmbito social. Basta imaginar a quantidade de portadores de incapacidade total e 
permanente para o trabalho, vítimas de acidentes e dependentes, hoje, da previdência social.

Esses dados se confirmam nos dias atuais, junto do Instituto Nacional de Previdência e Assistência Social (INSS), em 2002, R \$ 7,2 bilhões de reais, em gastos do país, para o pagamento de benefícios por acidentes e aposentadorias especiais; em 2003, somaram R \$ 8,2 bilhões, levando à perda de $2,3 \%$ a $4 \%$ do produto interno bruto (PIB), por ano, com mortes e acidentes do trabalho (BRASIL,2004).

Estes são apenas alguns dramas humanos que costumam envolver as vítimas de acidentes do trabalho e seus familiares, especialmente as de classes sociais menos favorecidas, as mais atingidas por esse tipo de infortúnio, pois são os que mais se submetem aos trabalhos rudes, com riscos mais acentuados. Todos esses sofrimentos, físicos ou psicológicos podem ser evitados ou reduzidos ao mínimo, pela aplicação correta de medidas adequadas aos acidentes do trabalho.

Ora, se os trabalhadores puderem conhecer a epidemiologia dos acidentes, a legislação pertinente, (e, isto é inclusive previsto na NR-5), e ainda contextualizá-los (os acidentes), perante as transformações no mundo do trabalho, isentos de preconceitos e estigmas, acreditamos que isto provocará uma conscientização crítica do problema; daí sim, poderemos falar em promoção da saúde nos ambientes de trabalho.

Um outro fato que chamou nossa atenção, diz respeito à falta de equipamento de proteção, o equipamento de proteção individual (EPI), como pode visualizado pela ata da reunião dessa CIPA (ATA DE JULHO DE 2002, QUADRO 2.2., ANEXO I).

Falta de luvas na câmara fria e uniformes...Deficiência no retorno de uniformes da lavanderia. Devido à elaboração do novo logotipo da empresa, houve atrasos na entrega dos novos uniformes, assim como na compra de EPI's (ATA DE JULHO DE 2002). 
Consideramos que esse assunto deva ser tratado com muita seriedade, pois é previsto pela legislação, inclusive com NR específica, a NR-6, cuja obrigação do empregador é a de substituir o EPI imediatamente, quando danificado ou extraviado, já que, sabidamente, protege de alguns agravos; porém o EPI é também polêmico, quando se pretende fazer prevenção de acidentes do trabalho, pois não basta somente equipar o trabalhador, sem alterar as condições de trabalho. Em virtude das considerações anteriores, o tema necessita de mais atenção por parte dos dirigentes e trabalhadores dessa empresa, ficando aqui então nossa observação em relação a esta questão.

Outra observação importante é a de que os aspectos sociais, quer voltados para os acidentes, quer à sua prevenção, devem merecer destaque nas campanhas preventivas dos infortúnios do trabalho; a ênfase aos problemas sociais, no entanto, não deve encobrir as outras consequiências também danosas, isto é, as falhas técnicas e administrativas, ainda mais comprometedoras na segurança do trabalho. Pretendemos, agora, verificar o entendimento sobre educação em saúde, efetivando as atividades educativas, propriamente ditas elas devem corresponder a atividades de conscientização e, conseqüentemente, de promoção à saúde dos trabalhadores dessa empresa em estudo. Pergunta-se: Será que nessa empresa as ações educativas estão ocorrendo de fato? Por meio de que conseqüências?

\subsubsection{Os meios utilizados em educação em saúde, segundo os "cipeiros"}

Todas as atas lidas, no ano de 2000, registram a ocorrência de 7 reuniões, sabendo que, em todas houve a discussão de temas ligados à educação; em 2001, nas 12 reuniões, os “cipeiros" sempre discutiram práticas educativas; no ano de 2002, houve 8 reuniões. Verifica- 
se que o tema educação aparece também como uma constante nas discussões entre os “cipeiros", (ANEXO D).

Em relação aos entendimentos dos “cipeiros" sobre educação em saúde, as respostas obtidas relacionam-se às atividades e meios utilizados, ou seja, o entendimento vem, sob a forma de atividades. Então, apesar de não possuírem uma definição precisa do que seja a educação em saúde, o conceito aparece descrito de diversas maneiras, tais como: cursos, treinamentos, palestras, campanhas, orientações, panfletos, reuniões, auditorias e reciclagem, inclusive um "cipeiro" nos deu exemplos do seu entendimento sobre a educação (QUADRO 2.3., ANEXO I).

"A CIPA deve estar à frente, acompanhada pelo SESMT em organização de campanhas educativas" (cipeiro1).

"Tenho trabalhado na execução de material impresso (mapas de risco), levantamento de riscos preferenciais, reuniões e discussões em grupos de trabalho[...]São todos as atividades de divulgação de assuntos ligados à saúde individual e coletiva. Podemos citar: hábitos alimentares, abstinência de fumo e álcool, cuidado com doenças transmissíveis" (cipeiro 2).

“A CIPA tem todas as condições de educação em saúde na empresa, através de palestras, orientadores especializados, ou até mesmo pelos membros da CIPA, se treinados" (cipeiro 7).

A postura adotada nas reuniões é de ouvinte, receptor...o técnico lá na frente fala e eles ouvem sem questionar, somente dois são mais questionadores...apesar de terem uma compreensão empírica da realidade da fábrica, não falam, parece que têm medo de falar bobagem (Observação de 13-11-01).

Porém, a descrição surgiu em forma de palavras como orientar, promover e instruir.

"Tem como objetivo observar e relatar condições de risco nos ambientes de trabalho e solicitar medidas, para reduzir até eliminar os riscos existentes e/ou neutralizar os mesmos, discutir os acidentes 
ocorridos, encaminhando ao SESMT e ao empregador o resultado da discussão, solicitando medidas que previnam acidentes semelhantes e, ainda, orientar os demais, quanto à prevenção de acidentes" (cipeiro 1)

“A CIPA tem, como prerrogativas promover a divulgação da prevenção de acidente, utilizando, para isso, treinamentos e atividades dinâmicas, se reúne para discutir todos os assuntos relativos às ocorrências de acidentes e apontar soluções para se evitar que tais acidentes se repitam, também é o elo de comunicação entre os níveis operacionais e a alta administração da empresa, para promover a segurança, higiene e organização dos ambientes de trabalho" (cipeiro $3)$.

"Promover palestra, folhetos, orientação sobre a saúde dentro da empresa e fora dela, para que possam ir ao trabalho, sem nenhum problema" (cipeiro 9).

Assim posta, a educação serve como um instrumento de dominação, justificada em pensamentos, totalmente contrários às teorias de Marx e Freire, nos quais a educação seria justamente o espaço onde, apesar de todas as contradições, a possibilidade de emancipação seria maior. E também esta concepção aparece muito ligada aos meios formais de educação, o que explicita um pré-conceito; o educar é privilégio de alguns, como o SESMT ou o especialista.

Destacamos a consciência do "cipeiro" de que, uma vez aprendido, o conhecimento irá para além do espaço da empresa e será aplicado em situações diferentes:

"É um termo no qual dou muita importância, pois todo o conhecimento passado não é utilizado simplesmente na empresa e sim em casa, na rua" (cipeiro 6).

Nosella (2002) nos afirma que o trabalhador deve ser um sujeito ativo em sua própria educação, uma educação participativa, ligada à vida, formadora do homem integral, que, desenvolva valores morais e estéticos que permitam adquirir habilidades com o objetivo de 
encaminhamento na vida. Permitirá desenvolver o sentido social e solidário e não o egoísmo individualista e competitivo, ou seja, uma educação que promova a reflexão, a atitude crítica e autocrítica libertadora.

Cocco (1991) revela que as práticas de educação em saúde deveriam estar voltadas a perspectiva mais democrática, que configurasse o processo de desenvolvimento da consciência sanitária, como também possibilitasse a instrumentalização dos indivíduos na construção de seu processo de cidadania.

Freire (1989b) nos diz que, para criar consciência, o sujeito tem que problematizar e tem que estar dentro do problema, sendo ele mesmo um agente de mudança, pois, à medida que a situação-problema proporciona o conhecimento ao trabalhador, fornece-lhe os meios para transformar sua ação.

Foi discutido o alto índice de acidentes com queimaduras ocorridos na fábrica, com sugestões de como evitá-los, como: a identificação dos pontos de maior risco, a mudança no tipo de uniforme e treinamento dos funcionários de uma área da empresa (ATA DE OUTUBRO DE 2000).

Concordamos com a abordagem, uma vez que a educação, nos ambientes de trabalho é entendida por nós, como um instrumento eficaz de produção de conhecimentos, aplicados à realidade do trabalho, com vistas a uma prevenção de doenças e acidentes e promoção da saúde. Só poderá cumprir seu papel, se possibilitar o desenvolvimento das partes envolvidas, respeitando as especificidades, as habilidades e os bloqueios, ao proporcionar conhecimento, proporcionando também os meios para o alcance da mudança.

\subsubsection{Práticas/atividades de educação formal}

Conforme dissemos anteriormente, a educação, nessa CIPA, aparece muito ligada à educação formal, instituída em forma de curso, treinamento, palestras, apresentações. 
Atribuímos isso a um reflexo do que sempre foi visto por todos nós, em nossas escolas, com raras exceções, ou melhor, uma educação estritamente catequizadora, nos moldes jesuíticos. Dessa maneira, na hora de pensarmos na educação em saúde, a representação social que vem à tona é justamente aquela que tivemos. Parece que essa identificação da educação em saúde com as atividades formais de transmissão de informações, deve-se também a uma falta de criatividade, trazida pela alienação do trabalho, (QUADRO 2.4., ANEXO I).

Foi discutido uma ação de sensibilização dos funcionários, através de palestras internas (ATA DE MAIO DE 2000).

Foi sugerido que se fizessem novas palestras, observando os riscos de acidentes com os novos funcionários contratados (ATA DE DEZEMBRO DE 2001).

Nesse aspecto, um outro fator relevante, ao nosso ver, diz respeito às mudanças que vêm ocorrendo em nossa sociedade, por meio do fenômeno da globalização. A política neoliberal que se instalou, apoiou a reestruturação das relações sociais de produção, financiou a terceira revolução industrial, cujo desdobramento, na esfera político-social, favoreceu a precarização e flexibilização do trabalho (MENDONÇA, 2002).

No entanto, as mudanças no mundo do trabalho e nos processos produtivos, são orientadas pela busca do aumento da produtividade e redução dos custos; geralmente, acompanhadas pela redução do número de postos de trabalho, pelos critérios de remuneração dos trabalhadores e não são necessariamente seguidas pela melhoria das condições de trabalho (LINO e DIAS, 1995).

Todos esses fatores levaram a uma mudança no perfil de adoecimento da classe trabalhadora, com predomínio dos acidentes graves e doenças, provocadas pela organização do trabalho, como a Lesão por esforço repetitivo (LER) e as doenças mentais, conforme já mencionado, tendo contribuído para a alienação no trabalho. 
Nesse sentido, Dejours, Abdoucheli e Jayet (1994) nos dizem que o caminho de encaminhamento ao trabalho saudável é o que respeita a identidade do trabalhador, em sua construção plena, dentro de um trabalho, cuja organização é eticamente prescrita, respeitando potenciais e limites da condição humana, conduzindo à criatividade e à realização de um trabalho de alta qualidade.

Para Campos (2000), uma saída para o trabalho alienado seria um método de apoio à co-gestão de processos complexos de produção, baseado em experiências políticas de planejamento, de análise institucional e de educação continuada, enfim, onde houvesse a criação de espaços laborais, que estimulasse a construção de um novo conceito de trabalho, configurando um modo essencial de expressão dos sujeitos. "Na verdade, talvez valesse apostar na criação de espaços de trabalho que permitissem conciliar a sobrevivência com a produção de obras, dois objetivos básicos do trabalho" (CAMPOS, 2000, p. 53). Por obra, entendemos os jeitos singulares de inventar o processo de trabalho.

Retomando a questão central do presente trabalho que é a educação em saúde nos ambientes de trabalho, entendida como as práticas cotidianas que levam à possibilidade de os indivíduos se tornarem autônomos, exercerem seus direitos como cidadãos e contribuírem para a conscientização; conseqüentemente, para a melhoria da saúde no ambiente fabril e fora dele, práticas que estão intimamente ligadas à promoção da saúde.

Verifica-se que o tema promoção da saúde tem sido proposto, como discussão em diversos fóruns da saúde pública brasileira, cujas principais estratégias de difusão dos conceitos, associados a documentos, predominantemente, são cartas e declarações das conferências internacionais. Trata-se da re-emergência e não do surgimento do termo, na prática da saúde pública ocidental, porque o movimento da promoção da saúde é orientado por um conceito de saúde, não apenas como resultado das condições concretas de vida, mas também, como recurso objetivo e subjetivo de indivíduos e comunidades. Segundo Lefévre 
(2000), enquanto a prevenção é provisória, a promoção visa à eliminação permanente ou, pelo menos, duradoura da doença, porque busca atingir as causas e não apenas o impedimento de as doenças se manifestarem nos indivíduos, (QUADRO 2.7., ANEXO I).

Houve treinamento para os terceiros responsáveis pela montagem dos paletes. Também, informou que após houve uma melhora significativa na montagem destes paletes (ATA DE ABRIL DE 2002).

Por concebermos que a promoção à saúde contempla a educação, verificamos que somente, em alguns momentos, a CIPA em sua atividade educativa formal, conseguiu problematizar e gerar consciência. Assim, ela conseguiu parcialmente educar e facilitar a promoção da saúde. Resta-nos agora verificar se, nas atividades informais, este fato também ocorreu.

\subsubsection{Práticas/atividades de educação informal}

Além das atividades formais em educação, nessa empresa, houve também atividades de educação informal, tais como comunicados internos, exibição de filme, veiculação de propaganda, instalação de painéis, placas, mural da CIPA e SIPAT's. Dentre elas, destacamos a SIPAT, por ser uma semana dedicada à prevenção dos acidentes do trabalho, prevista legalmente; por envolver a prática do trabalho em equipe multiprofissional, que pressupõe um intercâmbio, uma evolução das partes, para alcance da totalidade, podendo ser um espaço privilegiado, em que se repensem teorias e inovações da concepção, acerca do processo saúde-doença e das melhorias das relações e das condições de trabalho. Num âmbito mais geral, podem desenvolver conceitos, definir práticas e prescrições em saúde, e, ainda, especificamente abrir espaço às manifestações culturais, sociais e produtivas, relacionadas ao trabalho. 
No que se refere às demais práticas educativas, placas, murais, painéis, vídeo e propaganda, cabe observar, até que ponto essas práticas são realmente libertadoras, criadoras de consciência crítica, ou mais uma forma de persuasão e de controle dos trabalhadores, (QUADRO 2.5., ANEXO I).

Foi sugerido a criação do mural da CIPA (ATA DE MAIO DE 2000).

As atas das reuniões serão expostas nos painéis da empresa, para que todos os colaboradores fiquem cientes do andamento da CIPA (ATA DE JULHO DE 2002).

Essas atitudes denotam uma democratização no processo das discussões da CIPA; no entanto, essas medidas são previstas por lei.

Nesse sentido, Freire (1994, p. 32) nos diz que

[...] educar e educar-se, na prática da liberdade, é tarefa daqueles que sabem que pouco sabem-por isto sabem que sabem algo e podem assim chegar "a saber" mais-em diálogo com aqueles que, quase sempre, pensam que nada sabem, para que estes, transformando seu pensar que nada sabem em saber que pouco sabem, possam igualmente saber mais.

Para Brandão (2003, p. 80),

A Educação Permanente é uma concepção dialética da educação, como em duplo processo de aprofundamento, tanto da experiência pessoal quanto da vida social, que se traduz pela participação efetiva, ativa e responsável de cada sujeito envolvido, qualquer que seja a etapa de existência que esteja vivendo. 
Estes pensamentos asseguram que a educação pode ser libertadora, à medida que contribui para a igualdade, muito diferente da persuasão, que contribui, gradativamente para a criação da desigualdade.

Estamos em constante geração de novos conhecimentos, por meio da análise de impressões que recebemos. O conhecimento humano é orientado para a ação, baseado em regras, e está em constante mutação, podendo ser transmitido por outros ou pela nossa própria experiência. Assim, tem como elementos: o conhecimento específico, a habilidade, a experiência e valores. Então, o conhecimento é um processo criativo, baseado na capacidade de apreender fatos e direcioná-los a uma ação, diferentemente da informação, que, para nós, é um meio e não um fim, o que constitui diferença entre informar e educar, visto que uma é pontual e outra, a segunda, é entendida como um processo dinâmico, com envolvimento das partes, visando a uma transformação. Conseqüentemente, nossa percepção é a de que, apesar da observação e registro das atividades educativas, elas não configuram, ainda, transformação de consciência, igualdade e liberdade. Desse modo, passaremos agora aos conteúdos das SIPAT's.

\subsubsection{As SIPAT's}

A SIPAT tem suas origens no Decreto $\mathrm{n}^{\circ} 68255$, de 16/02/71, que instituiu, em caráter permanente a Campanha Nacional de Prevenção de Acidentes do Trabalho, em uma década em que os dados de acidentes e doenças de trabalho tinham picos estratosféricos. Porém, a legislação não explicava como seria sua execução, apenas a incumbência à Secretaria de Medicina e Segurança do Trabalho, sua realização. Nesse ano, promulgou-se a Portaria $n{ }^{\circ}$ 3233, de 09/07/71, que foi regulamentada. Ela era realizada, em razão de três itens: O Congresso Nacional de Prevenção de Acidentes do Trabalho, a medalha de honra ao mérito da 
Segurança do Trabalho e a SPAT (Semana de Prevenção de Acidentes do Trabalho). A SPAT devia ser desenvolvida, uma vez por ano, em nível regional, no mês de maio, pelas Delegacias Regionais do Trabalho, e um dos seus pontos altos seria a convenção das CIPA's das empresas sediadas no estado. Esses aspectos legais, por não terem sido revogados continuam vigentes (MACHADO FILHO, 2003).

Contudo, o Ministério do Trabalho, ao ver o alcance motivador da SPAT, na tentativa de levá-la para as empresas, através da $4^{\mathrm{a}}$ regulamentação da CIPA, instituída pela Portaria n ${ }^{\circ}$ 3456, de 03/08/77, criou a SIPAT que também deveria acontecer no mês de maio. Posteriormente, a $5^{\text {a }}$ regulamentação da CIPA que surgiu em 08/06/78, com o advento das NR's, pela Portaria n ${ }^{\circ} 3214$, ratificou a obrigatoriedade da SIPAT, com a modificação de que ela poderia ser executada anualmente, porém em qualquer mês.

Hoje, a $6^{\text {a }}$ regulamentação, verificada ocorrida na Portaria $n^{\circ} 08$, de 1999, que constitui o texto vigente da CIPA, continua apoiando a SIPAT. As três regulamentações anteriores da CIPA não citavam nada sobre as SIPAT's. A SIPAT deve ser considerada uma Campanha de Segurança e, portanto, a sua finalidade básica é divulgar conhecimentos de segurança e saúde no trabalho, com o propósito de desenvolver a consciência da importância de eliminar os acidentes do trabalho e de criar uma atitude vigilante, que permita reconhecer e corrigir condições e práticas capazes de provocar acidentes, em prol da melhoria contínua das condições e ambiente de trabalho.

A responsabilidade pela organização e promoção da SIPAT cabe à CIPA, que deve promover, anualmente, em conjunto com o SESMT, onde houver, a Semana Interna de Prevenção de Acidentes do Trabalho (SIPAT). No entanto, na prática, ela acaba sendo realizada pelo serviço de segurança da empresa, cujo tema central, a escolha das palestras e palestrantes, acabam conferindo-lhe um caráter pouco democrático. 
O envolvimento com a realidade da SIPAT deste ano por parte dos "cipeiros" foi quase nulo, foram às reuniões, porém não opinaram, quem mais falou foi o técnico de segurança e o presidente da CIPA (Observação de 09-10-01).

No momento de descrever a SIPAT, os "cipeiros" foram categóricos, em afirmar-lhe a inexpressividade, por ser pontual, não se utilizar de uma linguagem acessível e de temas do cotidiano do trabalhador; dessa maneira, não atinge seu propósito, (QUADRO 2.6., ANEXO I).

"As SIPATs realizadas tem sido pouco expressivas, a grande maioria que comparecem o faz para "cumprir tabela" (cipeiro 7).

[...]Mas em recente pesquisa feita pelos engenheiros de Segurança do Trabalho da Universidade Paulista, apenas $15 \%$ das empresas inquiridas não teve dúvidas em afirmar que uma SIPAT, se bem planejada, constitui-se num excelente método de incentivo à prevenção de acidentes (MACHADO FILHO, 2003).

Tal dado corrobora o que os “cipeiros" escreveram sobre as SIPAT's nessa empresa; apenas um "cipeiro" afirmou que a SIPAT era educativa.

“As SIPAT's costumam ser bem educativas e "animadas". São promovidas palestras, teatros e são bem aceitas por todos e ajudam muito na prevenção de acidentes do trabalho" (cipeiro 9).

Em relação à programação das SIPAT's, cumprem-se as exigências legais, abordando algum tema ligado à segurança do trabalho e temas de saúde geral, por exemplo, AIDS e tabagismo. Procuramos saber o porquê desse programa, junto de alguns profissionais da área ou em sites de saúde e segurança. Descobrimos que a legislação determinava a participação da CIPA em campanhas internas específicas, (Portaria n 3257 de 22/09/88, sobre o tabagismo, e Portaria $\mathrm{n}^{\circ} 3195$ de 10/08/88, sobre AIDS). Atualmente, somente a AIDS continua como tema 
obrigatório e legalmente imposto e exigido (NR-5). Os demais temas variam, apesar da importância que eles possuem. O que falta, ao nosso ver, são temas mais abrangentes, vinculados às condições e relações de trabalho, e que realmente levem a uma reflexão efetiva sobre saúde e trabalho.

Em relação à forma, como os temas foram abordados, de maneira geral, pude observar que, predominou a forma "bancária", contrária à educação conscientizadora, assistencialista e sem muito diálogo, realizada por profissionais sem preparo pedagógico-educacional.

Zócchio (1980) revela que a educação, no que tange à segurança do trabalho, assume importância excepcional em dois aspectos muito amplos: educação da administração, alta supervisão e técnicos, para que programas adequados possam ser efetivados, como também sejam devidamente levados em consideração, nos processos industriais, aspectos técnicos da segurança nos trabalhos em geral; principalmente, nos projetos e inovações, na educação dos empregados em geral, incluindo supervisores, afim de contar com a execução satisfatória dos programas estabelecidos por parte da supervisão e com a obediência às suas regras, por parte dos empregados em geral.

Assim, os serviços de segurança e de saúde e a CIPA devem estabelecer o plano geral de educação, juntamente com o setor de treinamento, quando existente e a ordem de prioridade das matérias e atribuição de responsabilidades na execução do plano. Os meios educacionais devem ser utilizados, visando a esse fim. Também os membros da CIPA devem receber instruções, em curso, hoje, legalmente instituído, antes da posse, de modo a levar a um desempenho melhor, na tarefa que lhes cabe, no programa geral (NR-5).

A cada especialidade existente na empresa, pode-se ministrar um treinamento de segurança, por meio de cursos rápidos, que devem ser preparados ou adaptados pelo serviço de segurança e saúde, a CIPA, de acordo com as características e necessidades da empresa. Em todos os cursos técnicos ou administrativos que vierem a ser ministrados, a segurança e a 
medicina do trabalho pode assegurar o seu lugar, como uma das matérias. É importante que se consiga levar o grupo a uma conclusão satisfatória do assunto tratado, em favor dos objetivos da segurança do trabalho, deixando-o livre, para colocar questões relativas ao ambiente de trabalho.

Trazemos aqui, algumas constatações de forma tradicional das SIPAT's, porém consideramos importante diversificar o formato principalmente em relação aos conteúdos, fugindo de questões mecanicistas e moralistas. Por entendermos que o mundo se dá pelas relações homem-natureza, isto é, pelo trabalho o homem transforma a natureza e é transformado por ela, logo, é importante utilizar a SIPAT para estudar os condicionantes histórico-culturais a que está submetido o homem, nas suas variadas formas de atuação, além de oferecer cursos gerais e específicos, com noções gerais sobre a saúde do trabalhador, legislação e políticas na área. É importante contextualizar essa teoria, levando de modo acessível, problematizada, por meio de exemplos da realidade concreta, o que conduz à conscientização do grupo sobre a importância das diversas formas de prevenção. Então, as SIPAT's deveriam tratar de questões relacionadas à realidade do trabalhador e procurar trazer pessoas que discutissem os temas, de modo problematizador, criando assim as condições para o desenvolvimento de uma consciência crítica.

\subsubsection{Problemas e soluções identificados na prática educativa}

Ao serem questionados sobre os problemas e soluções para a prevenção de acidentes de trabalho na empresa, 4 dos “cipeiros" sugeriram mais informação, treinamento, conscientização e o aumento da credibilidade da CIPA (QUADRO 2.7., ANEXO I).

"Minha sugestão é que se faça um grupo para discussão das novas diretrizes e traçar os objetivos claros da CIPA, traçando um plano 
concreto, voltado principalmente para o resgate da imagem da CIPA" (cipeiro 2).

Foi comentado sobre o programa de treinamento sobre a prevenção de acidentes realizado, e solicitado cooperação dos supervisores no agendamento e liberação dos funcionários, para continuidade e maior participação de todo processo (ATA DE SETEMBRO DE 2000).

Essas falas são importantes, construtivas, pois indicam em forma de sugestões, o treinamento e informação à CIPA, bem como a necessidade de envolvimento da diretoria da empresa, a conscientização, como nos coloca Paulo Freire, de forma coletiva, na práxis, e que surge, como benefício, da própria necessidade da população.

As reuniões da CIPA, em geral, se mostraram insuficientes, mas úteis, pois não alteraram o controle estruturado em espaços rígidos de poder, embora, às vezes, tenham demonstrado contradições. Ao concretizar isso, abre espaço, para que se visualizasse o duplo sentido dos fatos. Por exemplo, como cobrar comprometimento e envolvimento dos "cipeiros", se os supervisores não se envolveram com o processo educativo na CIPA, não liberando os funcionários-trabalhadores para o seu aprimoramento? Como superar o descrédito nas ações da CIPA, se a própria direção da empresa não lhe dá a devida atenção e poder de resolução?

Em seguida, o Técnico de Segurança ressaltou a falta de comprometimento dos "cipeiros", e pontualidade, número reduzido de "cipeiros" presentes nas reuniões (ATA DE AGOSTO DE 2002).

"A CIPA deveria receber mais atenção e deveria ser tratada com mais apoio e seriedade pelas chefias" (cipeiro3).

Segundo opinião de outro funcionário é importante a presença do superior imediato durante as reuniões/diálogos (ATA DE AGOSTO DE 2002). 
A empresa e sua diretoria não privilegiam as ações da CIPA e assim as chefias estão mais preocupadas com a produção (Observação de 1309-02).

Parece-nos que faltou o apoio necessário às atividades da CIPA e o entendimento de que ela, por suas ações educativas, pode e deve transformar a realidade. Além disso, talvez a CIPA devesse ser mais crítica em relação à empresa. Sabemos que isso é muito difícil, em face das condições materiais em que se encontra a empresa, como também, frente às já relatadas transformações no mundo do trabalho. Porém, acreditamos que tenha faltado à CIPA, em estudo, problematizar, desalienar, trabalhar a cultura da empresa, e, conseqüentemente, a cultura dos “cipeiros", visando à transformação progressiva, repensada coletivamente, articulada a outras mudanças e potencializada pela mudança intra e interpessoal.

Percebemos ainda que, nessa CIPA, os "cipeiros" não alcançaram o objetivo de analisar o espaço fabril, já que, após o levantamento de riscos, deveriam ser instituídos o mapa de riscos e o mural da CIPA. Até o inicio desta pesquisa, essas iniciativas não haviam sido tomadas, apesar de previstas na NR-5. O planejamento das ações e a confecção do mapa de risco, como facilitador da compreensão dos trabalhadores sobre "os riscos" a que estão submetidos, também apareceram nas respostas, o que é importante, pois à medida que se desenvolve a atividade de confecção do mapa de risco, o "cipeiro" visualiza melhor o seu ambiente de trabalho e pode planejar ações de inspeção e orientação para os demais trabalhadores. Acreditamos que a confecção do mapa de risco seja momento privilegiado de levantamento das condições de trabalho, e discussão sobre o processo de trabalho e os agravos aos quais os trabalhadores estão submetidos. Porém, geralmente os "cipeiros" não têm participado dessa elaboração, descaracterizando, assim, a proposta do mapeamento de riscos no local de trabalho. 
O mapeamento das condições de trabalho ou mapa de risco tornou-se obrigatório no Brasil, por meio da portaria $\mathrm{n}^{\circ}$, de 18/08/92 do MTb, que alterou a NR-9, estabelecendo a obrigatoriedade às empresas que tenham CIPA, sendo que as informações para a sua construção foram, após, transferidas para a NR-5, que trata da CIPA. Ela é quem deve desenvolvê-lo, em conjunto com os trabalhadores, inclusive as empreiteiras. Porém, o texto atual, apesar de prever o mapa de risco, não diz como fazê-lo; assim, dá margem para que seja feito, de qualquer modo, descaracterizando, mais uma vez, o mecanismo, que poderia abrir espaço à discussão sobre o trabalho, os processos e sua organização.

Nessa CIPA, sem autonomia e liberdade para tomada de decisões, pois "amarrada" a coisas que independiam da sua vontade, houve um empobrecimento de ações educativas, resultante da eficácia insuficiente, nas ações de prevenção e promoção da saúde. Assim, verificamos que os "cipeiros" nem sempre conseguiram a solução de problemas, seja de ordem educacional ou de trabalho, (QUADRO 2.7.; QUADRO 3.2., ANEXO I), bem como a criação de novos espaços de decisões, apesar de, repetidamente, oferecerem a eles esse espaço, configurado na legislação, NR-5.

Por conseguinte, o entendimento de que toda prática em educação se faz e se refaz, por meio do conhecimento, é que buscaremos compreender neste momento, quais conhecimentos os "cipeiros" têm sobre saúde do trabalhador, para assim poderem interagir com os demais trabalhadores e provocar mudanças essenciais no ambiente de trabalho, em que estão inseridos.

\subsubsection{A relação educação e trabalho nessa empresa}

\subsubsection{O ambiente de trabalho}


Seria esperado que os "cipeiros", como transmissores do conhecimento aos demais trabalhadores, dominassem algumas concepções básicas em saúde e segurança; porém, no caso estudado, essa descoberta, mais uma vez, chamou-nos a atenção. Também levamos em conta que, o que pode nos parecer limitação cognitiva, para os "cipeiros" pode ser a representação social daquilo que eles vivenciaram aquele momento. Nesse sentido, nenhuma resposta pode ser considerada errada

Encontramos resposta daquele trabalhador que não identifica o risco ergonômico, próprio de atividades administrativas, por exemplo: posturas inadequadas, uso excessivo de computador. A questão do posto de trabalho, por meio do microcomputador ou pelos terminais de computador é uma das dúvidas mais freqüentes das empresas, dúvida que em geral procede, pois a associação entre postos de trabalho de condições primitivas e a incidência de tenossinovites e outras lesões, por traumas cumulativos nos membros superiores, é bastante alta (CANADIAN CENTER FOR OCCUPATIONAL HEALTH AND SAFETY, 2000; COUTO, 1998).

"Não há riscos ocupacionais em minha área de trabalho (escritório)" (cipeiro 2, QUADRO 3.1., ANEXO I).

Conforme referência, presenciamos ainda transformações na forma de gestão, na organização do trabalho, nos equipamentos e máquinas utilizados, na segurança e forma de controle dessa empresa. Essas modificações geraram muita insegurança, para os trabalhadores envolvidos.

Muccillo (2004) afirma que o ser humano, em tais condições, poderá apresentar defesas psíquicas, que muito longe de patológicas são uma forma de manejo sadia, pois representam a vontade de sobreviver, apesar das agressões, veladas ou não. Porém, a convivência, em constante conflito, determina a prevalência da chamada acomodação psíquica, e daí desequilíbrios e prejuízos à saúde. Ainda, se o ser humano quiser superar uma 
situação, mas o próprio trabalho não permite, ou, pelo contrário, é fonte de constante pressão, ele passa a ser fatigante e desprazeroso, causando-lhe, propriamente, nessas condições, uma doença.

Dejours, Abdoucheli e Jayet (1994) afirma que "O trabalho torna-se perigoso ao aparelho psíquico, quando ele se opõe à sua livre atividade" (DEJOURS; ABDOUCHELI; JAYET, 1994, p. 24). Dessa forma, a saúde ocupacional tem se deparado, através dos tempos, com doenças que têm se manifestado, em forma de boom ou picos; primeiro, surgiram as pneumoconioses; depois as leucopenias; em seguida, as dermatites e as perdas auditivas induzidas pelo ruído. Nos últimos vinte anos, as doenças ósteo-musculares, dentre as quais, destacamos as de membros superiores como as tenossinovites, epicondilites e as de coluna vertebral, principalmente as hérnias de disco. Essas patologias são responsáveis, atualmente, por $80 \%$ das doenças ocupacionais e têm, como principal causa, as condições ergonomicamente desfavoráveis dos postos de trabalho. Conhecida, em séculos passados, como a "doença dos escribas", a LER atinge atualmente, trabalhadores de diversos setores produtivos. Tem, como fatores contributivos importantes, a força muscular, repetitividade e velocidade de movimentos (COUTO, 1998).

No que se refere à saúde dos trabalhadores, é importante considerar a persistência ainda atual, de antigas formas de produção, com baixa capacitação tecnológica, processos artesanais e ou mecanizados, inspirados no setor industrial, nos princípios fordistas e tayloristas, sob relações de trabalho diversas, desde o trabalho escravo, distintas formas de parcerias, trabalho informal e alta rotatividade de mão de obra.

O trabalho, que deveria ser fonte de satisfação, crescimento, desenvolvimento de potenciais pessoais e coletivos, cada vez mais, aumenta o número de adoecimentos, em decorrência de desordens afetivas e mentais, provindas de sofrimentos que se originam dele. A explicação vem das constantes mudanças nos modelos de gestão e das adaptações de cunho 
mercadológico, ocorridas nas empresas, que se refletem junto ao coletivo dos trabalhadores, que para adaptar-se, fica sujeito a muitas pressões, que, por sua vez, fazem aumentar a ansiedade, a tensão muscular, o cansaço, o desânimo e a falta de iniciativa e criatividade.

Lembre-se que o ser humano é um ser de relações sociais, historicamente determinadas e dialeticamente constituídas; por isso, o relacionamento é tão importante, pois, na relação com o outro, nós nos vemos, refletimos sobre os conceitos e práticas e mudamos comportamentos. Se assim somos, possuímos capacidade infindável de possibilidades, desejos, necessidades e realizações. Nesse quadro, a nossa práxis, atividade orientada a um fim, deveria ter uma consistência e coerência que nos levassem a transformações, sempre orientadas, segundo nossos interesses. Porém, nem sempre é assim que as coisas ocorrem, pois somos pressionados constantemente a agir, segundo o modelo hegemônico, principalmente em nosso ambiente de trabalho: mesmo que o discurso seja de mudança, a prática que nos direciona é notoriamente controladora.

Em virtude disso, queremos mencionar o fato de o trabalhador não dominar os meios de produção, e, assim, não poder se expressar, como ser criativo e complexo que é. Desse modo, temos visto que o enfraquecimento do Estado também tem dado "brecha" para que as grandes corporações se organizassem, no sentido de dominarem mais ainda as relações capital-trabalho. Porém, as empresas, mantendo-se dentro da lógica do neoliberalismo, que pressupõe um crescimento econômico, como também um crescimento pessoal, contraditório do nosso ponto de vista.

Quanto mais vimos o desenvolvimento das nações, mais temos visto também o empobrecimento dos povos. No entanto, aí também encontramos contradições que emergem justamente da impossibilidade de sermos plenos, de termos qualidade de vida. Se de um lado, o neoliberalismo promete crescimento econômico, de outro, impõe normas que desrespeitam as pessoas e os trabalhadores. Conquanto as organizações nos privem dos desejos, o 
capitalismo impõe inúmeras necessidades novas a cada dia. Finalmente, se, por sua vez, a "reegenharia organizacional" trouxe inovações, com a incorporação de conceitos e práticas, voltadas ao sentimento de inclusão do trabalhador no processo produtivo, trouxe também a idéia da educação, como instrumento de dominação e alienação; conseqüentemente, a exclusão das discussões realmente significativas que provocassem transformações da realidade do mundo do trabalho (CAMPOS, 2000).

Nessa relação, contraditória e dialética, também assistimos ao surgimento de uma força de resistência, por parte dos trabalhadores, que pode ser visualizada, por exemplo, em alguns movimentos sociais. Não constitui o alvo desse estudo, entrarmos na discussão sobre a legitimidade desses processos. Iremos nos deter do controle no contexto industrial, suas formas de legitimação e superação.

Ao retomarmos a questão dos riscos ocupacionais, na empresa estudada, nota-se que a maioria dos "cipeiros" soube exemplificar a questão da existência de algum risco ocupacional, no ambiente de trabalho, cujas observações mostraram vários deles, (QUADRO 3.1., ANEXO I).

"Sim, no meu ambiente de trabalho há riscos. Posso citar por exemplo, piso escorregadio, ruído elevado, calor intenso, tubulações quentes, equipamentos em movimento." (3).

Seria de esperado que a técnica desse conta das questões levantadas, acerca dos problemas de maior incidência nessa empresa, segundo os dados do PCMSO e de observação da pesquisadora. No entanto, para que tais mudanças fossem eficazes, entendemos que os aspectos técnicos, especificamente, não dariam as respostas às questões de saúde do trabalhador, pois elas dependem também de outras mudanças e de condições políticas, para que pudessem ser eficazes. Qualquer solução técnica deve vir sempre acompanhada de transformações de cunho político e de mudanças na organização do trabalho. Então, mais uma 
vez, fica a idéia de que a pedagogia no trabalho também deve se transformar, no sentido de alcançar o objetivo de possibilidade de conscientização.

É preciso rever conceitos, práticas e estratégias que visem à detecção de sentimentos de alarme, junto dos trabalhadores, treinando suas potencialidades, resgatando o verdadeiro significado do trabalho, que deveria integrar políticas de recursos humanos às de segurança e medicina do trabalho. Isso concretizaria o alcance da plenitude das relações humanas no ambiente de trabalho e, ainda, a consciência de que o educando é o grande responsável pela sua transformação.

Em relação ao entendimento dos trabalhadores sobre o Serviço Especializado em Segurança e Medicina do Trabalho (SESMT), apenas dois "cipeiros" conseguiram defini-lo legalmente; porém, nenhum deles menciona a sua atividade principal, ou seja, a prevenção. É interessante, verificar como o SESMT é identificado a acidentes, indisposições, visto como local de treinamento e ajuda, talvez pela condição em que os SESMT's das empresas se encontram, (QUADRO 3.1., ANEXO I).

\begin{abstract}
"A minha empresa possui o SESMT. Utilizo os seus serviços assim que necessário. Quando sofro algum acidente de trabalho, logo procuro o SESMT, ou quando estou indisposto no trabalho. Participo de palestras e convenções quando possui também" (cipeiro 8).
\end{abstract}

O SESMT é um serviço composto de profissionais credenciados pelo Ministério de Trabalho. Sabe-se que a empresa é obrigada a mantê-lo quando possui mais de cem empregados, por suas atividades e seus riscos se enquadrarem nas tabelas da NR-4. A quantidade de empregados e o grau de risco determinam o número de engenheiros, médicos, enfermeiros e técnicos de segurança do trabalho à composição do serviço especializado da empresa. O SESMT tem uma atuação em todos os níveis técnicos e administrativos das empresas; portanto, uma colocação vertical, que compreende: planejamento, desenvolvimento 
das atividades prevencionistas, coordenação e fiscalização dessas atividades e assessoramento específico a todos os órgãos e níveis hierárquicos da empresa (ZÓCCHIO, 1980).

Sua criação gerou todo um posicionamento ideológico das autoridades do MTb, no sentido de demonstrar que a implantação dos serviços tenha sido fundamental, para a melhoria das condições de saúde e segurança no trabalho; conseqüentemente, explicava a queda do número de acidentes de trabalho, conforme registraram as estatísticas oficiais da Previdência Social, a partir de 1976 (POSSAS, 1987).

Então, desde a sua criação, o SESMT tem um caráter ideológico. Segundo Scopinho (2003, p. 72)

De fato, para as empresas parece que a saúde e segurança no trabalho ainda continuam sendo fatores de otimização da produção tornando-se agora também um importante instrumento na busca da qualidade, ou melhor, na construção de uma imagem, de uma aparência de qualidade e de respeito aos direitos humanos.

Observa-se que, o SESMT, muitas vezes está nas empresas, por uma questão de obrigatoriedade legal e por questões de gestão de qualidade. Torna-se, dessa maneira, mero espectador em saúde e segurança do trabalhador.

No entanto, pensamos que o SESMT também pode ter uma outra função, a de conduzir questões relacionadas à saúde e segurança, de um modo que gere consciência sobre a saúde dos trabalhadores, no âmbito das doenças e acidentes do trabalho. Por exemplo, quando ao diagnosticar uma determinada situação de saúde, considere, os aspectos bio-psicossociais; ao traçar um perfil de morbidade dos trabalhadores, divulgue essas informações de modo sistemático à CIPA e, ao realizar campanhas de prevenção e promoção à saúde, contextualize junto dos sujeitos as razões que motivaram tais iniciativas.

Para compreendermos o entendimento dos "cipeiros" acerca do ambiente de trabalho, buscamos apreender seus conhecimentos sobre os riscos ocupacionais ou agravos, sobre o 
SESMT e sobre os EPI's por eles utilizados. Então, em relação aos EPI's, os "cipeiros" conseguem dar exemplos práticos do seu uso. Cabe explicitar que as medidas de controle dos riscos ou agravos ambientais podem ser classificadas em coletivas e individuais, atuantes na fonte ou na trajetória dos agentes, existentes no ambiente de trabalho, (QUADRO 3.1., ANEXO I).

"Sim, óculos de proteção, protetor de ouvido, luvas e botas de borracha" (cipeiro 4).

As medidas coletivas são aquelas que beneficiam um grande número de pessoas, como exemplo: cabinas de comandos, acusticamente construídas, parapeitos, rodapés, etc. Essas medidas podem ser adotadas, se eliminarem o agente ambiental na fonte ou na trajetória, pois, nos dois casos, há uma redução do agente produzido e as medidas individuais são aquelas aplicadas no corpo do trabalhador, atuando diretamente no agente ambiental.

Pelas atas e questionários, podemos observar que as medidas mais facilmente visualizadas são as que remetem aos EPI's: a noção de prevenção continua centrada no uso dos EPI's, uma vez que os técnicos, em geral, acreditam numa única saída, equipar e proteger o trabalhador. No que se refere à adoção dos EPC's, pouco se discute.

Em relação às medidas que realmente interfiram nas causas dos acidentes, como a organização do trabalho, pouco ou nada se discute. Talvez, ela expresse a grande dificuldade que os "cipeiros" apresentaram, ao nosso ver, em relação à situação do trabalho concreto; contudo, ocorreu-nos a pergunta: será que eles não conseguem enxergar ou será que se sentem impotentes, diante de tantas dificuldades impostas? Será que a relação na CIPA, no momento do levantamento dos temas e da discussão sobre as causas dos acidentes, é colocada de forma impositiva, tipo: “eu sei, você não sabe?"

Nesse momento, foram muito importantes as anotações no diário de campo da pesquisadora, pois ajudaram a buscar respostas para essas dúvidas. Pude perceber que as 
reuniões sempre foram conduzidas da mesma forma impositiva, até autoritária, uma forma "bancária" e vertical, na concepção de Paulo Freire. Dessa forma, os "cipeiros" ficavam mais calados: mais ouvindo do que discutiam, problematizando as questões levantadas durante as reuniões. Pareciam pensar: Ora, "se eles sabem e têm a solução, por que e prá que vou me manisfestar?"

A relação pedagógica estabelecida foi anti-dialógica, contrária ao pressuposto básico do método Paulo Freire que prevê o diálogo, revelando que, nas relações estruturais, rígidas, verticalizadas, como a da CIPA, não há espaço para a experiência dialógica, participativa; apenas, para a escuta e a obediência; logo, era esperado que tivéssemos participação e problematização insuficientes, cabendo-nos a análise da última.

\subsection{2. Problemas e soluções identificados no cotidiano da fábrica}

Aqui também aparece a problematização, como uma característica importante para o "cipeiro", que pretende atingir os funcionários com a sua prática educativa. Porém, a problematização que também gera consciência não pôde ser notada, apesar da capacidade de busca de soluções, acenando para uma perspectiva de mudança. (QUADRO 3.2., ANEXO I).

Funcionário comentou sobre uma área, que logo após a porta de entrada, havia um buraco e estava sem a faixa de proteção, que um acidente naquele local causaria danos irreparáveis (ATA DE AGOSTO 2001).

Falta de luvas na câmara fria e uniformes (ATA DE AGOSTO 2002).

Problemas de informação dos funcionários, para melhorar isto, divulgação dos resultados atingidos pela CIPA, aumentar os cursos de formação dos funcionários, cobrar mais o uso dos EPI's (cipeiro 3). 
Na concepção de Paulo Freire, a problematização é a reflexão que alguém exerce em um conteúdo, fruto de um ato, ou no próprio ato, para agir melhor com os demais na realidade, sendo que esta realidade é a do mundo da cultura e da história. Essa problematização dá-se no campo da comunicação, em torno de situações reais, concretas, existenciais ou conteúdos intelectuais, que se referem também ao concreto, demandando a compreensão por parte dos sujeitos que os problematizam.

Entretanto, apesar, da falta dos EPI's no ambiente de trabalho ser visível e constante, ata de julho e agosto de 2002, o "cipeiro" 3, aponta como solução a cobrança do uso do EPI, evidenciando, carência de medidas com o objetivo de prevenção dos acidentes.

Falta de luvas na câmara fria e uniformes...Deficiência no retorno de uniformes da lavanderia. Devido à elaboração do novo logotipo da empresa, houve atrasos na entrega dos novos uniformes, assim como na compra de EPI's (ATA DE JULHO DE 2002, QUADRO 2.2., ANEXO I).

Os EPI's e os EPC's aparecem com freqüência, embora exista a falta de contextualização aprofundada, em relação ao processo e à organização do trabalho, pois apesar de o trabalho ser um meio de desenvolvimento de nossas potencialidades, ele também pode provocar doenças. Isso nos interessa problematizar: o tipo de organização do trabalho, condicionando o surgimento de determinados agravos que podem provocar as doenças. A título de exemplo, nessa empresa, a LER-DORT aparece como uma preocupação freqüente entre os trabalhadores, no entanto, isso não é mencionado pelos "cipeiros" durante as reuiniões da CIPA, somente pelo SESMT, (QUADRO 3.2., ANEXO I).

Durante a reunião, o técnico e o auxiliar de enfermagem da unidade, alertaram para a necessidade dos colaboradores realizarem $\mathrm{o}$ revezamento de funções em sua área de atuação, a fim de se evitar lesões por esforço repetitivo (ATA DE ABRIL 2002). 
Destacamos, nessa relação, contraditória e dialética, a preocupação com a organização do espaço fabril (QUADRO 3.2., ANEXO I).

Foi discutido o problema com a higiene dos sanitários da fábrica, em geral; principalmente, o que atende ao pessoal do carregamento, contratado pela Transportadora, sendo que foi entregue pela empresa, em excelentes condições de uso, e não está havendo o trabalho de limpeza e conservação (ATA DE DEZEMBRO 2000).

Buscamos também revelar o motivo com que os "cipeiros" planejam a execução, e descobrimos que, apesar de todas as dificuldades apresentadas, são elas: ordem de compreensão das atribuições da CIPA sobre a educação em saúde, bem como os conceitos básicos em saúde do trabalhador; ordem operacional, como a não liberação para as reuniões, e falta de compreensão, por parte das chefias; ordem ideológica, como a culpabilização pelos acidentes e a educação anti-dialógica e domesticadora, tanto nas reuniões como nas SIPAT's. Apesar de tudo isso, os "cipeiros" conseguiram, de certa maneira, executar minimanente ações educativas. Essas práticas formais e informais que buscaram contribuir para que os trabalhadores tivessem mais conhecimento sobre os acidentes e sobre a saúde, não conseguiram, porém, a tomada de consciência que visava à sua prevenção.

Se considerarmos as categorias educação e trabalho como fundamentais para o entendimento da questão da educação em saúde do trabalhador, privilegiaríamos a CIPA e os “cipeiros", por compreendermos que são os responsáveis, legalmente e de direito, pela difusão a educação nos ambientes de trabalho. Detivemo-nos finalmente no papel desempenhado pelo SESMT, em relação a essa questão, uma vez que este último deve auxiliar a CIPA, no tocante à educação do trabalhador.

\subsubsection{O SESMT em sua atividade educativa}


Segundo dados do próprio MTE para o ano de 2000, o Serviço Especializado em Segurança e Medicina do Trabalho (SESMT) está presente em 0,83\% das empresas brasileiras. A constatação nos mostra que a maioria das empresas não possui o serviço, devido ao número de trabalhadores, ao enquadramento no grau de risco, ou à negligência na própria legislação, onde a fiscalização não existe ou é ineficaz. Isso em um Brasil que gasta mais de $\mathrm{R}$ \$ 20 bilhões/ano, em função dos acidentes e doenças do trabalho, sendo um dos recordistas em acidentes do trabalho (SINDICATO DOS TÉCNICOS DE SEGURANÇA DO TRABALHO, 2002).

As estatísticas também mostram que, à instituição do serviço, até o ano de 2001, os números de acidentes foram reduzidos. Destacamos como outros fatos importantes: as mudanças na legislação; a fiscalização das DRT's; a contribuição dos profissionais de segurança e saúde, através das CIPA's; o aumento da consciência dos trabalhadores e a já conhecida subnotificação, que ainda persiste, em nosso meio, apesar de todos os esforços empreendidos.

Conforme já mencionamos, a obrigatoriedade dos serviços de segurança do trabalho nas empresas constitui obra do Decreto-lei n. ${ }^{\circ} 229$, de 27 de fevereiro de 1967, que introduziu modificações no texto do Capítulo V da CLT, que trata da segurança e da medicina do trabalho. Essa obrigatoriedade, no entanto, só foi regulamentada em 17 de julho de 1972, por intermédio da portaria n. ${ }^{\circ}$ 3.237. do Ministério do Trabalho e da Previdência Social. Essa regulamentação suprime falhas na previsão de preparo dos profissionais que atuariam no campo prevencionista já que a lei estabelecia o número mínimo de profissionais para as empresas enquadradas em determinada extensão e grau de risco e a obrigatoriedade, que passaria a vigorar em primeiro de janeiro de 1974, mas só entrou, em vigor, um ano mais tarde, apenas parcialmente, tendo como objetivo reduzir os índices de acidentes do trabalho que colocavam o Brasil na condição de campeão mundial em ocorrências. Apesar da 
diminuição dos índices de acidentes, ao longo dos anos, estamos distantes de uma situação aceitável, o que nos permite ainda figurar, entre os mais altos índices de acidentes no mundo. Após longo período de indecisões legislativas, com portarias que modificavam o que fora estabelecido anteriormente, o assunto transformou-se em uma das normas regulamentadoras, baixadas pela Portaria n. 3.214 , de 8 de junho de 1978, do MTb (ZÓCCHIO, 1980). Deveria tratar-se de um esforço de reflexão sobre o trabalho, mas este conhecimento não está pronto e acabado, seja por sua dinamicidade ou porque não estamos acostumados a apontar as suas consequiências.

Embora constitua hoje uma imposição legal, cresce o número de empresas que reconhecem o valor dos serviços especializados em segurança do trabalho, os mantendo-os por convicção. Sob o título de seção ou departamento, dependendo do tipo de organização ou da nomenclatura adotada pela empresa, o serviço de segurança assume uma série de atribuições determinadas pela NR-4, da Secretaria de Segurança e Medicina do Trabalho, do Ministério do Trabalho, além de outras, que deverá assumir, para atendimento às peculiaridades da empresa. Isto é, embora as atribuições institucionais sejam bastante amplas e os princípios universais de segurança devam ser obedecidos, os serviços de segurança do trabalho devem adaptar-se organizacional e funcionalmente ao tipo de organização, extensão, atividades e cultura da empresa (ZÓCCHIO, 1980).

Observamos que nessa empresa, o SESMT, também, muitas vezes, tornou-se, mero espectador em saúde e segurança do trabalhador, pois apesar da tentativa de interferir nos processos de trabalho, as decisões, geralmente, "esbarravam" em questões gerenciais, constitutivas do processo de produção nessa empresa. Então, pareceu-nos que o SESMT estava aí, por questão de obrigatoriedade legal e de gestão de qualidade, sendo suas funções mais técnicas-administrativas, do que propriamente, gerenciais ou interferidoras na organização do trabalho. 
Zócchio (1980) nos diz ainda que, segurança do trabalho e prevenção de acidentes são duas expressões que, muitas vezes, se confundem. Há os que as consideram a mesma coisa, os que procuram definí-las separadamente e os que as colocam na ordem inversa de atuação. Entretanto, as definições encerram um valor inestimável para o bom entendimento do assunto. Quanto mais bem aplicadas forem as medidas de segurança, maior a probabilidade de êxito na prevenção dos acidentes. Isso já está comprovado na prática, pela experiência de muitas empresas. Essa experiência autoriza afirmar que a segurança do trabalho, racionalmente aplicada, resulta em:- mais produção, principalmente em função da estabilidade da mão-de-obra;- menor perda de tempo e de materiais, menos reparos em máquinas, instalações etc.;- mais equilíbrio emocional e mais ânimo entre os trabalhadores;- mais estabilidade nos custos operacionais;- melhor ambiente social na comunidade. Isto ratifica a afirmação de que a segurança do trabalho é um benefício social e econômico para a empresa, para os empregados e para a sociedade, como um todo. Esses benefícios, infelizmente, nem sempre são mensuráveis; embora reconhecendo os benefícios da prevenção de acidentes, nem sempre o empresário consegue alcançá-los plenamente, pela carência de serviço de segurança e de CIPA's mais atuantes, ou de programas de segurança mais adequados às necessidades da empresa.

Concordamos com este pensamento, pois acreditamos na prevenção da saúde, bem como na promoção á saúde, enquanto promotoras da qualidade de vida, coloque-se, ainda, que, apesar do cotidiano do ambulatório ser muito rico em significados, não dá conta de explicar o resultado da organização da produção em nossa sociedade, que contamina a qualidade de vida e não atende às necessidades do ser humano em sua enorme complexidade.

A qualificação e a quantidade do pessoal especializado no SESMT estão previstas na NR-4. Supervisores de segurança, engenheiros de segurança, médicos do trabalho, enfermeiros do trabalho e auxiliares de enfermagem formam a equipe especializada em 
segurança e medicina do trabalho. É muito importante que os respectivos responsáveis nas empresas conheçam detalhadamente a NR-4 e interpretem corretamente suas instruções. Nessa empresa, o SESMT era formado por uma médica, um auxiliar em enfermagem do trabalho, um engenheiro e um técnico de segurança.

O SESMT deve auxiliar a CIPA, sendo que as práticas de educação em saúde devem ser planejadas, de acordo com a população atendida, e neste sentido, as suas atividades devem estar vinculadas à realidade da empresa. No caso de a empresa estudada, foi realizada a distribuição de folhetos explicativos sobre temas ligados a saúde individual dos trabalhadores, na sala de espera do ambulatório, (QUADRO 3.3., ANEXO I).

Marano (2001, p. 19) coloca que

O Serviço de Medicina do Trabalho de uma empresa tem como finalidade precípua zelar pela saúde do trabalhador, promovendo seu bem-estar físico, mental e social, visando paralelamente à continuidade operacional e ao aumento da produtividade.

Este autor, mais adiante, recomenda ainda que "o médico mantenha-se na neutralidade, no meio termo, atendendo, ao mesmo tempo, às necessidades exigidas pelo empregador e o trabalhador".

No mínimo duas considerações sobre estas falas nos vêm à mente: Primeiro: como manter a saúde do trabalhador, sem afetar a produção? Se a organização do trabalho provoca doenças, sem alterar o modo de organização da produção, fica difícil manter a saúde dos trabalhadores. Segundo: como se manter neutro, atendendo a necessidades que são antagônicas? Acreditamos que a neutralidade não existe, nem do ponto de vista filosófico e nem operacional, pois estamos de um lado ou de outro.

Conforme Dias (1993), a saúde do trabalhador, como área do conhecimento e especialidade médica, apresenta as características básicas: busca da compreensão das relações 
entre trabalho-doença; possibilidade de mudança dos processos de trabalho, na direção de "humanização" do trabalho; exercício de abordagem multidisciplinar e intersetorial para a resolução de problemas, buscando a superação de estratégias cristalizadas; participação dos trabalhadores, como capazes de compreender e intervir.

Por serintegrante do SESMT dessa empresa, na tentativa de desenvolvimento de uma atitude madura e crítica sobre meu próprio trabalho, percebo que não tivemos um papel limitado em relação às questões ligadas à saúde do trabalhador; tentamos sempre aliar a técnica e o conhecimento científico disponível às ações humanas, éticas e sociais; porém, no tocante à educação em saúde, vejo que nossa atividade foi limitada, pelo menos, em relação aos temas abordados, os quais surgiram por interesse do SESMT, por sugestão da diretoria, como cumprimento de uma programação exigida pela saúde pública local, não expressando o envolvimento direto dos trabalhadores. Isto pode ser vizualizado, QUADRO 3.3, ANEXO I, por meio da distribuição de folhetos sobre temas em saúde, na sala de espera do ambulatório e no refeitório.

Essa afirmação, em tom de confissão, deve, no entanto, ser relativizada, pois o grande desafio do médico do trabalho consiste em planejar e implantar nas empresas, sejam elas públicas ou privadas, ações preventivas, implementando programas de educação em saúde. Essa função se torna difícil, por razões de formação, cujo conteúdo não é transmitido ao médico, nas escolas médicas, por falta de entendimento desse seu papel. Isso acontece, inclusive na legislação, que nem mesmo contemplava essas práticas, no texto da NR-7 (PCMSO), em vigor até dezembro de 1994.

E mais: infelizmente, os profissionais que atuam junto aos SESMT's não têm percepção e integração, junto dos trabalhadores, no que se refere à compreensão do ambiente de trabalho, o que dificulta a adequação de técnicas que visem à redução até a possibilidade de eliminação dos acidentes. Se isso, não for possível, a eliminação do agravo. 
Isto reflete a razão de, no mundo da educação nos ambientes de trabalho, termos nos mostrado ineficientes, normativos e, alicerçado nossas práticas em atitudes catequizadoras e não promotoras de conscientização, que geram mudanças de paradigmas e que promovam a saúde do trabalhador.

Nesse sentido, o médico do trabalho, tanto quanto o enfermeiro, o assistente social, o psicólogo, todos ao lado dos trabalhadores, em uma mudança de paradigma de atuação, que são elos importantes na grande corrente que entende qualidade de vida não apenas o controle de doenças, mas, principalmente a maneira de evitá-las. Dessa forma, irão atuar de forma preventiva, tanto nas operações laborais do dia-a-dia, quanto nos programas de treinamento e capacitação, minimizando ou eliminando os riscos ambientais existentes. Em virtude disso, acreditamos que os programas de educação em saúde são um caminho para alcançar este objetivo.

Alguns passos devem ser pensados na hora de implantação desse tipo de programa, entre eles: ouvir o trabalhador; definir horários para as atividades destinadas ao programa de educação em saúde; realizar levantamento, por meio das fichas de atendimentos, absenteísmo e principais problemas de saúde; elaborar questionário abrangente sobre dúvidas e questionamentos dos trabalhadores, e, ainda, ouvir o setor de recursos humanos, os supervisores e a diretoria da empresa.

Assim, concebemos que a educação, compromissada com a possibilidade dos trabalhadores se tornarem emancipados, deve proporcionar a compreensão da realidade social e natural, com o fim de dominá-la e transformá-la, devendo ser criativa e criadora de espaços no trabalho, consoantes com os objetivos dos trabalhadores.

Por isso, é importante dialogarmos sobre saúde, pois, à medida que o trabalhador conhece sua realidade, pode alterá-la. Isso é justamente o grande alcance da educação promotora da promoção em saúde, configurado na possibilidade de mudança de concepção, 
de uma práxis renovadora e libertadora que facilite a criação de obras. Aqui, também se reflete a importância da identificação de novos espaços de educação em saúde nos ambientes de trabalho. Considerando que a educação é um processo dinâmico, fundamentalmente histórico, cujo caráter, eminentemente social, diz que a saúde e a educação possuem uma interligação e características fundamentais para a melhoria das condições de trabalho, em nossa sociedade. 


\section{6- CONSIDERAÇÕES FINAIS}

Durante a realização desta investigação sobre educação em saúde, nos ambientes de trabalho, aprendi que a educação não é um processo pronto e acabado, portanto os "cipeiros" e a pesquisadora deverão amadurecer algumas questões, ao longo do tempo; entre elas, a de que podemos educar e sermos educados constantemente.

Ao retomar os questionamentos iniciais, considero ter começado a trilhar um caminho de respostas, que espero sejam alternativas e criativas. Os dados coletados, junto dos sujeitos, mostraram que a postura adotada, no decorrer da pesquisa, obteve respeito e aprovação, em relação a uma parte dos participantes.

Ao pretendermos estudar a questão da educação em saúde do trabalhador, em uma empresa do setor de alimentos em Ribeirão Preto (SP) via CIPA, utilizamos uma perspectiva dialética e a teoria de Paulo Freire, como referências para a captação e exploração do objeto de estudo, análise e compreensão da realidade social, em sua historicidade, dinâmica de determinações e transformações. Revelamos um compromisso com o processo de movimento permanente que existe na natureza e na sociedade e a crença no princípio de que a sociedade, historicamente construída, pode ser transformada, superando-se as contradições, por meio da práxis.

Tomamos, em primeiro lugar, o cuidado de definir alguns conceitos fundamentais usados, para construir o quadro teórico da pesquisa. Em seguida, discutimos a construção do objeto, realizamos uma discussão sobre o instrumento de apreensão dos dados empíricos e entrada exploratória no campo da investigação.

Procuramos lidar, coerentemente, com as concepções acerca dos acidentes do trabalho, da doença profissional e da educação para a saúde; dentro dessa perspectiva. Entendemos que os acidentes do trabalho, as doenças profissionais ou relacionadas ao trabalho não ocorrem 
por questões de responsabilidade individual, mas decorrem de condições inseguras, insalubres e penosas, presentes nos ambientes de trabalho; dessa maneira, reafirmamos dados da literatura que, ao procurarem compreender os acidentes do trabalho na sociedade brasileira, conceberam-nos como uma forma de violência que se traduz em sofrimentos físicos, psíquicos e sociais, derivados do acidente em si, intensificando-se em toda a trajetória a ser percorrida pelo trabalhador, a partir da ocorrência do acidente do trabalho.

Essas interpretações de acidentes do trabalho e de doenças profissionais ou relacionadas ao trabalho, por sua vez, partem do raciocínio que o trabalho deve ser fator de desenvolvimento das potencialidades do homem e não sinônimo de ocupação. Nesse sentido, a categoria trabalho como fundamento da sociabilidade humana assume grande importância nos processos de crescimento e desenvolvimento do ser humano, que é a sua própria vida.

Concebemos a educação, por sua vez, como ato social, político e ideológico. Baseamo-nos na teoria de Paulo Freire que toma o trabalho como um mediador da relação do sujeito com o mundo, através do qual ele se forma, aprende e ensina: enfim, relaciona-se com a natureza, com os outros homens e com os valores, as normas, as regras sociais, isto e', com o mundo. O processo do educar, na visão de Marx, também propõe a conexão entre ensino e trabalho que é basicamente a apropriação da natureza de modo universal, consciente e voluntário, para modificá-la. Ao modificar a natureza e seu próprio comportamento em relação a ela, modifica a si próprio, como homem. Enfim, tanto o materialismo de Marx, quanto a pedagogia problematizadora de Paulo Freire colocam, como mediações importantes, a relação capital/trabalho para o entendimento do processo educativo.

Nesse quadro, os dados foram obtidos, primeiramente, por meio da observação simples e mapeamento dos setores da empresa, com duração de seis meses. Esse período incluiu a coleta de dados de acidentes do trabalho na empresa pela própria pesquisadora, que era médica do trabalho do Serviço Especializado em Segurança e Medicina do Trabalho 
(SESMT) nessa época. Assim, obtivemos a confirmação das hipóteses iniciais que direcionaram a coleta de dados deste trabalho de pesquisa e procedemos à aplicação de questionários com respostas abertas aos "cipeiros" e à observação participante, e registro das reuniões da CIPA, bem como a análise documental das atas dessas reuniões, desde o ano de 2000, com duração de dois anos.

Utilizamo-nos da abordagem qualitativa, já que possibilita apreensão dos fenômenos em sua totalidade, na direção de repensar a realidade para transformá-la - como também da análise temática dos conteúdos dos questionários respondidos pelos “cipeiros".

A análise documental foi realizada nos conteúdos das atas das reuniões da CIPA, nos conteúdos das Semanas de Prevenção Interna de Acidentes do Trabalho (SIPAT's), no Programa de Controle Médico em Saúde Ocupacional (PCMSO), no Programa de Prevenção de Riscos de Acidente (PPRA) e nos folhetos expositivos sobre segurança e medicina do trabalho, a serem divulgados pelos "cipeiros", e de uma prática de leitura na sala de espera do ambulatório e do refeitório, com temas ligados à saúde.

Um sistema de categorias foi criado com base nessas análises, são elas; a CIPA, segundo os "cipeiros"; a CIPA na realidade da empresa; e a relação educação e trabalho nessa empresa, sendo que elas foram divididas em subcategorias.

Sobre o conceito e as atribuições legais da CIPA, que está constituída desde 1997, vemos que não existe sistematização desses temas, e a finalidade de auxiliar na prevenção de acidentes do trabalho. Em contrapartida, também aparece a crença de que a CIPA, com suas reuniões, tem poder de transformação dessa realidade. As razões e motivações na participação da CIPA estão mais voltadas para o interesse coletivo que o individual, o que demonstra envolvimento e compromisso com a CIPA; em relação ao grau de realização e satisfação com a CIPA, os "cipeiros" revelaram que não têm feito o que desejavam. No planejamento das 
ações, o tema mais freqüente das reuniões da CIPA foi o da prevenção de acidentes, seguido da preocupação com a integridade física dos funcionários e da empresa.

$\mathrm{Na}$ execução dos planos educativos, destacamos práticas formais e informais. A educação formal foi instituída como palestras, apresentações e treinamentos, mostrando a necessidade de uma ampliação do conceito de educação. Em relação aos meios utilizados, houve o uso freqüente de palavras como "orientar", "promover", e "instruir". Além das atividades formais em educação, nesta empresa houve também atividades de educação informal, tais como comunicados internos, exibição de filme, veiculação de propaganda, instalação de painéis, placas, mural da CIPA e SIPAT's. Em relação às SIPAT's, os "cipeiros" consideraram-nas pouco expressivas, e verificamos que os temas foram abordados, de maneira geral, de forma "bancária", assistencialista e sem muitos diálogos, contrariamente à educação conscientizadora.

Em relação aos conceitos básicos e questões relativas à segurança do trabalho, a maioria dos "cipeiros" não teve uma definição do que seja risco ocupacional, equipamento de proteção individual (EPI) e a função do SESMT porém eles souberam exemplificar a existência de algum risco ocupacional no ambiente de trabalho, forma de uso dos EPI's, e também identificar a relação entre SESMT e prevenção de acidentes.

Dentre os problemas identificados e as soluções propostas, os "cipeiros" sugeriram mais informação, treinamento, conscientização e aumento da credibilidade da CIPA. Essa capacidade de buscar soluções acena uma perspectiva de mudança, que, no entanto, não se concretizou em sua prática de educação em saúde.

Verificamos que o SESMT auxiliou a CIPA, realizando a distribuição de folhetos explicativos sobre temas ligados à saúde individual dos trabalhadores, na sala de espera do ambulatório; contudo, também não problematizou a situação de saúde da empresa, em 
particular, e do trabalho, em geral, junto dos trabalhadores da empresa; em razão disso, deixou de realizar atividades de promoção à saúde.

Pudemos observar e demonstrar que na CIPA em estudo, houve reprodução de informações, que não resultou em expansão da consciência e, assim, transformação da realidade. Em alguns momentos, emergiram contradições importantes, como por exemplo: a falta de conhecimentos dos "cipeiros" acerca de questões de saúde e segurança no trabalho, apesar deles terem sido treinados, conforme prevê a legislação (NR-5). Sabe-se que a direção da empresa cobra ações da CIPA, sem dar-lhe as condições necessárias para a sua efetiva realização, assim como os temas das reuniões estão inseridos no contexto da prevenção de acidentes do trabalho, sem o aprofundamento adequado para questionamentos que levem a uma consciência e uma ação transformadora. Ora, essas contradições, conforme dissemos anteriormente, ao desnudarem a realidade dessa CIPA, também apontam a possibilidade de intervenção.

Verificamos que, apesar de todas as dificuldades apresentadas (ordem de compreensão, operacionalização e ideologia), os "cipeiros" conseguiram executar algumas ações educativas, sem que configurem um processo de promoção em saúde no ambiente de trabalho, em decorrência de não problematizarem em profundidade a situação concreta, não geraram a consciência crítica, necessária à transformação.

Os dados levantados nesta pesquisa, acerca da educação em saúde no ambiente de trabalho, demonstraram que as soluções dependem mais da vontade política que das providências técnicas que eliminem os problemas identificados. Esses dados evidenciaram, ainda, que o próprio trabalhador e a CIPA, no contexto do trabalho, não têm se utilizado das práticas educativas, numa perspectiva mais ampla, como uma das possibilidades fundamentais de discussão da qualidade de vida em geral e no trabalho, sobretudo, como promotoras de 
libertação. Há, portanto, necessidade de apropriação reflexiva da realidade, a fim de que possa haver mudança e compromisso de mudança, consigo e com os demais.

Apesar de o modelo centralizador adotado nessa e em outras empresas, pela crise atual em relação ao emprego, colocando os trabalhadores numa posição de imobilismo, de passividade e ajustamento, mesmo contra a vontade deles, outras CIPA's, em outras empresas privadas, podem ser reavaliadas.

Verificamos que as relações de trabalho têm se transformado, em decorrência da política neoliberal que vem sendo adotada no mundo ocidental, e, mais particularmente, em nosso país. Esse fato tem marcado o perfil da saúde dos trabalhadores, com mudanças significativas; assim, entendemos que o processo de educação em saúde do trabalhador na empresa estudada, também deve se transformar, para que possa alcançar, nessa CIPA, o objetivo de educar e promover a saúde nos ambientes de trabalho.

Por consegüinte, se está havendo uma mudança epidemiológica na área da saúde do trabalhador, provocada pelo capital, é necessário também que repensemos a prática educativa nos ambientes de trabalho, visando a uma superação dos modelos tradicionais, seja na forma, seja nos conteúdos.

Cabe a todos os profissionais envolvidos, o desenvolvimento da área de educação em saúde no trabalho, enquanto área do conhecimento e instrumento de conscientização, junto dos trabalhadores. Nesse sentido, é mister que a educação em saúde seja concebida como um campo transdisciplinar do conhecimento, em que haja uma interação, no sentido da construção do objeto, e que promova a reflexão sobre o futuro da educação dos trabalhadores, bem como a defesa da saúde do trabalhador em sua totalidade.

Cabe aos "cipeiros" estimular os demais trabalhadores a participarem ativamente da CIPA, auxiliando a compreensão coletiva dos processos de trabalho, a identificação das 
causas dos processos de adoecimento/acidentes de trabalho, e o conhecimento dos direitos legais dos trabalhadores e das empresas.

Finalmente, cabe ao Estado criar políticas efetivas em relação às CAT's e às informações de insalubridade e periculosidade, bem como fazer com que a composição da CIPA atenda aos interesses dos trabalhadores, o que favoreceria uma capacitação dos “cipeiros” em relação às suas áreas de atuação; cabe-lhe ainda, auxiliar na prevenção de agravos à saúde dos trabalhadores, como facilitador da criação de fóruns, nas empresas, que discutissem e refletissem sobre o trabalho.

Nesse sentido, gostaria de recuperar as questões que motivaram este trabalho investigativo: será que aprendemos essencialmente a reproduzir conhecimentos ou tem havido uma prática inovadora nas empresas, que possibilitaria a expansão das potencialidades dos sujeitos/trabalhadores e uma visão ampliada da realidade em que vivem, trabalham, gerando possibilidades de intervenção? Por que é importante produzir conhecimento sobre saúde? Qual o seu alcance? Por que identificar os novos espaços e atores pedagógicos, responsáveis pelos processos de educação dos trabalhadores?

Ora, nesta CIPA em estudo, houve a reprodução de conhecimentos que não resultou em expansão da consciência; desse modo, transformação da realidade. Porém, as contradições, ao desnudarem a realidade dessa CIPA, também apontam a possibilidade de intervenção.

Por conseqüência, é importante discutir sobre saúde, no ambiente de trabalho, pois à medida que o trabalhador conhece a sua situação, pode alterá-la, o que traduzo grande alcance da educação em saúde, que é a possibilidade de mudança de concepção; logo de uma práxis renovadora e libertadora que facilite a promoção em saúde. Nesse aspecto, reflete-se a importância da identificação de novos espaços de educação em saúde nos ambientes de trabalho, devido à carência de trabalho educativo, crítico, ligado à saúde e à segurança no 
trabalho. Parece-nos que essa discussão é, continuará sendo atual e um dos grandes desafios nas próximas décadas, as várias profissões que atendem ao trabalhador brasileiro. 


\section{REFERÊNCIAS *}

*De acordo com:

Diretrizes para a apresentação de dissertações e teses da USP: documento eletrônico e impresso/Vânia B.

Funaro, coord....et al. São Paulo:SIBI-USP,2004.

ALESSI, N. P.;PALOCCI FILHO, A.; PINHEIRO, S. de A.; SCOPINHO, R.A.; SILVA, G. B. Saúde e trabalho no Sistema Único de Saúde. São Paulo: Hucitec. 1994. 167 p.

ALESSI, N. P.; SCOPINHO, R. A. A saúde do trabalhador do corte da cana-de-açúcar. In: ALESSI, N.P. et al. Saúde e trabalho no Sistema Único de Saúde. São Paulo: Hucitec, 1994. p. 121-151.

ALESSI,N; MARCELLINO, I; CURVO,R; AUXILIADORA, R. O Programa de Alimentação do Trabalhador: estratégia real ou imaginária de política social de redistribuição de renda nacional. Ribeirão Preto, 2001. 15 p. (Relatório técnico UNAERP).

ALVES, A. C. Representação política, democracia e globalização. Revista do advogado de São Paulo. V.22, n.67, p. 99-101, ago. 2002.

ANTUNES, R. Os sentidos do trabalho. Ensaio sobre a afirmação e a negação do trabalho. 2. ed. São Paulo: Boitempo Editorial, 2000. 176 p.

BARDIN, L. Análise de conteúdo. Tradução Luís Antero Reto, Augusto Pinheiro. Lisboa: Edições 70, 1977. 156 p.

BERLINGUER G., A saúde nas fábricas. Tradução Hanna Augusta Rothschild. São Paulo: CEBES-HUCITEC,1983. 212 p. (la salute nelle fabbriche).

BOGDAN, R. C.; BIKLEN, S. K. Qualitative research for education: an introduction to theory and methods. Boston: Allyn and Bacon, 1982. 253 p.

BOGDAN, R. C; BIKLEN, S. K. Investigação qualitativa em educação. Tradução Maria João Alvarez, Sara Bahia dos Santos e Telmo Mourinho Baptista. Cidade: Porto Editora, 1994. 336 p. Título original: Qualitative research for education: an introduction to theory and methods.

BONCIANI, M. NR 5. Comentada. São Paulo: Editora VK, 1999. 64 p. 
BORDENAVE, J.E.D. Opções pedagógicas. In: ENCONTRO DE EXPERIÊNCIAS DE EDUCAÇÃO EM SAÚDE DA REGIÃO NORTE, 1982, Belém. Anais: Brasília: Centro de Documentação do Ministério da Saúde, 1982. p. 13-18. (Série F: Educação e Saúde, 3).

BORDENAVE, J.E.D. O que é participação. 8. ed. São Paulo: Brasiliense, 1994. 84 p. (Coleção primeiros passos).

Além dos meios e mensagens: introdução à comunicação como processo, tecnologia, sistema e ciência. 4. ed. Petrópolis: Vozes, 1987.

BOURDIEU, P. O poder simbólico. Lisboa: Difel, 1989. 74 p.

BRANDÃO, C. R. Pesquisa participante. 8. ed. São Paulo: Brasiliense, 1990. 128 p.

O Que é educação. São Paulo: Brasiliense, 2003. 116 p. (Coleção primeiros passos).

BRASIL. Lei ${ }^{\circ} 8080$ de 19.09.90. Dispõe sobre a criação do sistema único de saúde. Diário Oficial da União, Poder Executivo, Brasília, DF, 1990.

BRASIL. Lei $\mathrm{n}^{\circ}$. 8213, de 24.07.91, artigo 19. Dispõe sobre o conceito de acidentes do trabalho. Diário Oficial da União, Poder Executivo, Brasília, DF, 1991a.

BRASIL.Ministério da Assistência e Previdência Social. Apresenta leis, dados e matérias referentes à previdência social no Brasil. Brasília, 2004. Disponível em: $<$ http://www.mpas.gov.br> Acesso em:17 mar. 2004.

BRASIL. Ministério da Saúde. Promoção da saúde: Carta de Ottawa, Declaração de Adelaide, Sundsvall e Santa Fé de Bogotá.Tradução Luis Eduardo Fonseca. Brasília: Ministério da saúde, 1996.

BRASIL. Ministério da Saúde. Apresenta leis e dados referentes à saúde no Brasil. Brasília, 2000b. Disponível em: <http://www.ms.gov.br> Acesso em: 10 mar. 2002.

BRASIL. Ministério da Saúde. Apresenta leis, dados e matérias referentes à saúde no Brasil. Brasília, 2000c. Disponível em: <http:// www.saude.gov.br.promocao > Acesso em: 10 mar. 2002. 
BRASIL. Ministério do Trabalho. Apresenta leis e dados referentes ao trabalho no Brasil. Brasília, 1991b. Disponível em: <http://www.mt.gov.br> Acesso em: 15 mai. 2001.

BRASIL. Ministério do Trabalho. Normas Regulamentadoras. In: Segurança e Medicina do Trabalho. São Paulo: Atlas, 2000b. 256 p.

BRASIL. Ministério do Trabalho e Emprego. Apresenta leis, dados e matérias referentes ao trabalho no Brasil. Brasília, 2001. Disponível em: <http://www.mte.gov.br > Acesso em: 22 abr. 2003.

BRASIL Ministério do trabalho e Emprego. Apresenta leis, dados e matérias referentes ao trabalho no Brasil. Brasília, 2002b. Disponível em: <http://www.mte.gov.br $>$ Acesso em: 22 abr. 2003.

BRASIL. Portaria ${ }^{\circ} 8$ de 23/02/99. Dispõe sobre a NR-5. SST/MTb. Diário Oficial da União, Poder Executivo, Brasília, DF, 1999.

BRESLOW, L. Da prevenção das doenças á promoção da saúde. JAMA, São Paulo, v. 3, n 7, p. 11-15, ago. 1999.

BUSS, P.M. (Org.) Promoção da saúde e a saúde pública. Rio de Janeiro, 1998. 32 p. (mimeografado).

BUSS, P. M. Promoção e educação em saúde no âmbito da Escola de Governo em Saúde da Escola Nacional de Saúde Pública. Cadernos de Saúde Pública, Rio de janeiro, v. 15, p.7-13, out. 1999. Suplemento 2.

CAMPOS, G. W. de S. Um método para análise e co-gestão de coletivos: a constituição do sujeito, a produção de valor de uso e a democracia em instituições: o método da roda. São Paulo: Hucitec, 2000. 236p.

CANADIAN CENTER FOR OCCUPATIONAL HEALTH AND SAFETY (CCOHS). Ergonomia para escritórios. Canadá, 2000. 21 p. (mimeografado).

CANDEIAS, N. M. F. Conceitos de educação e de promoção em saúde: mudanças individuais e organizacionais. Revista de Saúde Pública, Rio de janeiro, v.31, n.2, p 1217, abr. 1997.

CASTELLS, M. Novas perspectivas críticas em educação. Porto Alegre: Artes médicas, 1996. 
CECCIM, R. B.; ARMANI, T. B. Educação na saúde coletiva: papel estratégico na gestão do SUS. Divulgação em Saúde para Debate, Rio de Janeiro, n.23, p. 30-56, dez. 2001.

COCCO, M.I.M. A ideologia do enfermeiro: prática educativa em saúde coletiva. 1991. 160 f. Dissertação de Mestrado. Faculdade de Educação, Universidade Estadual de Campinas, Campinas, 1991.

. Práticas educativas em saúde e a construção do conhecimento emancipatório. In: (coord.): BAGNATO, M.H.S.; COCOO, M.I.M.; SORDI, M.R.L. de. Educação, saúde e trabalho: antigos problemas, novos contextos, outros olhares/ Campinas: Editora Alínea, 1999. p. 63-70.

COHN, A. et al. Acidentes do trabalho: uma forma de violência. São Paulo: Brasiliense, 1985.

COHN A. et al. Pesquisa Social em Saúde. São Paulo: Cortez, 1992.

COUTO, H. de A. Como gerenciar a questão das LER/DORT. Belo Horizonte, 1998. 23 p. (mimeografado).

CHIZOTTI, A. Pesquisa em ciências humanas e sociais. 6. ed. São Paulo: Cortez. 2003. $164 \mathrm{p}$.

CHOR, D.; FAERSTEIN, E. Um enfoque epidemiológico da promoção da saúde: as idéias de Geoffrey Rose. Cadernos de Saúde Pública, Rio de Janeiro, v.16, n.1, p. 12-23, jan. 2000.

CZERESNIA, D. The concept of health and difference between prevention and promotion. Cadernos de Saúde Pública, Rio de janeiro, v.15, n.4, p. 15-23, out. 1999.

DEJOURS C., A loucura do trabalho: estudo de psicopatologia do trabalho. Tradução Ana Isabel Paraguay, Lúcia leal Ferreira. 5. ed. São Paulo: Cortez/Oboré, 1992.168 p. (Travail: usure mentale-essai de psychopatologie du travail).

DEJOURS, C.; ABDOUCHELI, E.; JAYET, C. Psicodinâmica do trabalho: contribuições da Escola Dejouriana à análise da relação prazer, sofrimento e trabalho.Tradução Maria Irene Stocco Betiol. São Paulo: Atlas, 1994. 145 p.

DEMO, P. Metodologia científica em ciências sociais, 3 ed. São Paulo: Atlas, 1995. 
DIAS, E. C. Evolução e aspectos atuais da saúde do trabalhador no Brasil. Boletim da Organização Panamericana de salud, México, v.115, n.3, p.14-22, set.1993.

. A atenção à saúde dos trabalhadores no setor saúde (SUS). Brasil: realidade, fantasia ou utopia? 1994. 335 f. Tese de Doutorado. Faculdade de Ciências Médicas, Universidade de Campinas, Campinas, 1994.

DUPAS, G. Economia global e exclusão social: pobreza, emprego, estado e o futuro do capitalismo. 2 ed. São Paulo: Paz e Terra, 1999. 198 p.

FALEIROS, V. P. O trabalho da política: saúde e segurança dos trabalhadores. São Paulo: Cortez, 1992. 312 p.

FLECHA, R. Novas perspectivas críticas em educação. Porto Alegre: Artes Médicas, 1996.

FÓRUM SOCIAL MUNDIAL. Apresenta discussões sobre temas discutidos durante a realização dos fóruns. 2000. Disponível em: <http://www.forumsocialmundial.org.br>. Acesso em: 15 mar. 2002.

FREIRE, A. M. Alfabetização no Brasil: a contribuição de Paulo Freire. São Paulo, 1996. 65 p. (mimeografado).

FREIRE, P. Educação e mudança. Rio de janeiro: Paz e Terra, 1979. 123 p.

. Conscientização: teoria e prática da libertação - uma contribuição ao pensamento de Paulo Freire. Tradução Kátia de Mello e Silva. 3 ed. São Paulo: Moraes,1980. 102 p.

Pedagogia do oprimido. 17 ed. Rio de janeiro: Paz e Terra, 1987. 184 p.

Educação como prática de liberdade. Rio de janeiro: Paz e Terra, 1989a. 150 p.

Educação como prática de liberdade. Rio de janeiro: Paz e Terra, 1994. 132 p.

.Extensão ou comunicação? Rio de janeiro: Paz e Terra, 1989b. 109 p.

Pedagogia da autonomia: saberes necessários à prática educativa. São Paulo: Paz e Terra, 1996. 148 p. 
Pedagogia da esperança: um reencontro com a pedagogia do oprimido. Rio de janeiro: Paz e Terra, 1997. 226 p.

FRIGOTTO, G. (org.) Educação e crise do trabalho: perspectivas de final de século. Petrópolis: Vozes, 1998. 230 p. (Coleção estudos culturais em educação).

GADOTTI, M. Pensamento pedagógico brasileiro. 4 ed. São Paulo: Ática, 1991. 125 p.

Concepção dialética da educação - um estudo introdutório. 8 ed. São Paulo: Cortez Associados,1992 .155 p. (Coleção educação contemporânea).

. Concepção dialética da educação: um estudo introdutório. $10^{\circ}$ ed. São Paulo: Cortez, 1997. $175 \mathrm{p}$.

Paulo Freire: uma biobibliografia. São Paulo: Cortez/Instituto Paulo Freire/UNESCO, 1996. 766 p.

GIL, A.C. Métodos e técnicas de pesquisa social. 5 ed. São Paulo: Atlas, 1999. 156 p.

GOLDENBERG, M. A arte de pesquisar: como fazer pesquisa qualitativa em Ciências Sociais. 2 ed. Rio de Janeiro: Record, 1998.

GOMES, J. B. Auto-avaliação: um caminho para a formação do profissional críticoreflexivo na enfermagem. 2001. 281 f. Tese de Doutorado. Escola de enfermagem de Ribeirão Preto. Universidade de São Paulo, Ribeirão Preto, 2001.

IANNI, O. A era do globalismo. Rio de Janeiro: Civilização Brasileira, 1996. 178 p.

INSTITUTO BRASILEIRO DE GEOGRAFIA E ESTATÍSTICA (IBGE) Apresenta dados sobre a população no Brasil. Brasília, 2000. Disponível em: <http://www.ibge.gov.br> Acesso em: 10 abr. 2002.

LACAZ, F.A.C. Saúde-doença e trabalho no Brasil. p. 131-141. In: Saúde meio ambiente e condições de trabalho: conteúdos para uma ação sindical. Brasil, 1995. São Paulo: CUT $219 \mathrm{p}$.

LAURELL, A.C. La salud - Enfermedad como processo social. Revista Latino Americana de Salud, México, n.2, p. 7-25, jun. 1982. 
LAURELL, A.C.; NORIEGA, M. Processo de produção e saúde. Trabalho e desgaste operário. São Paulo: Hucitec, 1989.

L'ABBATE, S. Educação e serviços de saúde: avaliando a capacitação dos profissionais. Cadernos de Saúde Pública, Rio de Janeiro, v.15, p. 32-43, out. 1999. Suplemento 2.

LEFÈVRE, F. Promoção de saúde: um novo modo de entender e praticar saúde. Brasília: 2000. 11 p. (mimeografado).

LESCURA, Y.; MAMEDE, M. V. Educação em saúde: abordagem para o enfermeiro. São Paulo: Sarvier, 1990. 134 p.

LINO, D.; DIAS, E C. A globalização da economia e os impactos sobre a saúde e segurança dos trabalhadores. Brasília, 1995. 5p. (mimeografado).

LÜDKE, M.; ANDRÉ, M.E.D.A. Pesquisa em educação: abordagens qualitativas. São Paulo: EPU, 1986. 99 p.

MACHADO FILHO, L. CIPA e SIPAT. Proteção. São Paulo, n. 139, p. 50- 64, Jul. 2003.

MACLAREN, P A vida nas escolas: uma introdução à pedagogia crítica nos fundamentos da educação. 2 ed. Porto Alegre: Artes Médicas, 1997. 353 p.

MANACORDA, M. A. Marx e a pedagogia moderna. Tradução Newton Ramos de Oliveira. 3 ed. São Paulo: Cortez, 2000. 198 p.

MARANO, V. P. Medicina do trabalho: controles médicos: provas funcionais. 4 ed. São Paulo: LTr, 2001. 375 p.

MARCELLINO, I. V. O sistema de informações sobre acidentes do trabalho no município de Ribeirão Preto, São Paulo, Brasil, no ano de 1998: uma abordagem qualitativa. 1999. 97 f. Dissertação de Mestrado. Faculdade de Medicina de Ribeirão Preto. Universidade de São Paulo, Ribeirão Preto, 1999.

MATTOSO, J. O Brasil desempregado - Como foram destruídos mais de 3 milhões de empregos nos anos 90. 2. ed. São Paulo: Editora Fundação Perseu Abramo, 1999. 47p.

MENDES, M. D.; CASAGRANDE, L. D. R. Trabalhadores e educação em saúde: utilização da metodologia problematizadora pelo enfermeiro do trabalho. Revista Brasileira de Saúde Ocupacional, São Paulo, v. 24, n.89-90, p. 09-14, ago. 1998. 
MENDES, M. D. Realidade ocupacional de trabalhadores de galerias de águas pluviais - educação conscientizadora para prevenção de doenças e acidentes do trabalho. 1993. 263 f. Dissertação de Mestrado Escola de Enfermagem de Ribeirão Preto, Universidade de São Paulo, Ribeirão Preto, 1993.

Enfermagem do trabalho e a educação em saúde: modelo de educação conscientizadora para "CIPAs" de empresas públicas. 1999. $213 \mathrm{f}$. Tese de Doutorado. Escola de Enfermagem de Ribeirão Preto, Universidade de São Paulo, Ribeirão Preto, 1999.

MENDES, R. Importância da ocupação como determinante da saúde-doença: aspectos metodológicos. Revista Brasileira de Saúde Ocupacional, São Paulo, v. 67, n. 17, p. 1830, set. 1989.

. (Org.) Patologia do trabalho. 2 ed. São Paulo: Editora Atheneu, 2003. 1924 p.

MENDONÇA, M. H. M.de. Sistema Único de Saúde no Brasil: entre o formal e o real, as vicissitudes da construção de uma intervenção pública moderna. Saúde em Debate, Rio de Janeiro, v. 26, n. 60, p. 9-24, jan./abr. 2002.

MINAYO, M. C. de S. O desafio do conhecimento: pesquisa qualitativa em saúde. São Paulo: Hucitec; Rio de Janeiro: ABRASCO, 1998. 269 p.

MINAYO, M. C. de S. et al. Pesquisa social: teoria, método e criatividade. 15 ed. Petrópolis: vozes, 2000. 80 p.

MUCCILLO, M. Organização do trabalho. Renovação urgente. Proteção. São Paulo, n. 126, p. 68-71, jul. 2004.

NAKATANI, A. Y. K. Processo de enfermagem: uma proposta de ensino através da problematização. 2000. 234 f. Tese de Doutorado Escola de Enfermagem de Ribeirão Preto, Universidade de São Paulo, Ribeirão Preto, 2000.

NOGUEIRA, D. P. Epidemiologia das doenças profissionais. Revista Brasileira de Saúde Ocupacional, São Paulo, v. 10, n. 39, p. 22, mar. 1982.

NOSELLA, P. Trabalho e educação. p. 27-41. In: GOMEZ, C. M., et al. Trabalho e conhecimento: dilemas na educação do trabalhador. 4 ed. São Paulo: Cortez, 2002. p. 2741. 
OLIVEIRA, A. U. de. Agricultura brasileira: as transformações recentes. São Paulo: Ed. Peres, 1994. $132 \mathrm{p}$.

OLIVEIRA, M.H.B.O. de O.; VASCONCELOS, L.C.F.de. As políticas públicas brasileiras de saúde do trabalhador: tempos de avaliação. Saúde em Debate, Rio de Janeiro, v.24, n. 55, p. 92-103, mai/ago. 2000.

OLIVEIRA, J. R. G. Os benefícios da ginástica laboral na prevenção das doenças ocupacionais. Revista CIPA, n. p. 72-80, jul. 2004.

PACHIR, J. Desenvolvimento de equipamento de proteção individual específico. Projeto apresentado como parte dos requisitos para conclusão do curso Técnico de Segurança do Trabalho do Centro de Formação Profissional "José Gomes da Silva" SENAC. Ribeirão Preto, 2002. 90 p.

PEZZATO, L. M.; COCCO, M. I. M. Educação e trabalho: algumas reflexões sobre a interlocução com a área da saúde. Saúde em Debate, Rio de janeiro, n.25, p. 30-38, jan./abr. 2001.

PINHEIRO, S. A. Estudo do processo trabalho-desgaste em trabalhadores de uma destilaria de álcool. 1992. 195 f. Tese de Doutorado Faculdade de Medicina de Ribeirão Preto, Universidade de São Paulo, Ribeirão Preto, 1992.

POSSAS, C. A. Avaliação da situação atual do sistema de informação sobre doenças e acidentes do trabalho no âmbito da Previdência Social Brasileira e propostas para sua reforma. Revista Brasileira de Saúde Ocupacional, São Paulo, v. 60, n.15, p. 43-67, mai. 1987.

RAMAZZINI, B. As doenças dos trabalhadores.Tradução Raimundo Estrela. São Paulo: FUNDACENTRO,1985. (De Morbis Artificum Diatriba).

REZENDE, A L. M.; NASCIMENTO, E.S. Criando histórias, aprendendo saúde: experiência com crianças de classes populares. São Paulo: Cortez, 1988.151p.

ROMANELLI, G. A entrevista antropológica: troca e alteridade. In: ROMANELLI, G.; BIASOLI-ALVES, Z.M.M. (Org.) Diálogos metodológicos sobre prática de pesquisa. Ribeirão Preto: Legis Summas/CAPES, 1998. p.119-133.

ROZENDO, C. A. et al. Uma análise das práticas docentes de professores universitários da área de saúde. Revista Latino-americana de Enfermagem, Ribeirão Preto, v.7, n. 2, p. 15-23, abr. 1999. 
RUBINSON, L.; ALLES, W. F. Health education. St. Louis: Editora WDF, 1984. 143 p.

SANTOS,U.P. et al. Sistema de vigilância epidemiológica para acidentes do trabalho: experiência da Zona Norte do município de São Paulo (Brasil). Revista de Saúde Pública, Rio de janeiro, v. 4, n. 24, p.93-286, ago. 1990.

SCHALL, V. T. Educação em saúde, novas perspectivas. Cadernos de Saúde Pública, v. 15, p.34-45, out. 1999. Suplemento 2.

SCOPINHO, R. A.; VALARELLI, L. L. (Org.) Modernização e impactos sociais: o caso da agroindústria sucroalcooleira na região de Ribeirão Preto (SP). Rio de janeiro: Fase, 1995. $143 \mathrm{p}$.

SCOPINHO, R. A. Vigiando a vigilância: Um estudo sobre a política e a prática em saúde e segurança no trabalho. 2000. 275 f. Tese de Doutorado Faculdade de Filosofia Ciências e Letras, Universidade Estadual Paulista, Araraquara, 2000.

Vigiando a vigilância: saúde e segurança no trabalho em tempos de qualidade total. São Paulo: Annablume/Fapesp, 2003. 284p.

SINDICATO DOS TÉCNICOS DE SEGURANÇA. São Paulo, 2002. Apresenta discussões legais sobre as normas de segurança do trabalho. O SESMT. Disponível em: <http://www.sintesp.org.br >. Acesso em: 10 nov. 2002.

SINDICATO DOS TRABALHADORES NAS INDÚSTRIAS METALÚRGICAS, MECÂNICAS E DE MATERIAIS ELÉTRICOS DE OSASCO E REGIÃO. Saúde do Trabalhador. In: XII SEMSAT. São Paulo, 1996. Anais: São Paulo, 1996. 6 p. (mimeografado).

SINGER, P.; CAMPOS, O.; OLIVEIRA, E. M. de. Prevenir e curar: o controle social através dos serviços de saúde. Rio de Janeiro: Forense-Universitária, 1988.

SOUZA, K. R. de. et al. O desenvolvimento compartilhado de impressos como estratégia de educação em saúde junto a trabalhadores de escolas da rede pública do Estado do Rio de Janeiro. Cadernos de Saúde Pública, Rio de janeiro, v. 19. n. 2, p. 15-24, mar./abr. 2003.

TEODORO, L C. S. Educar para participar. O enfermeiro e a prevenção da AIDS com alunos de 8. Série da cidade de Passos-MG. 1997. 209 f. Dissertação de Mestrado Escola de Enfermagem de Ribeirão Preto, Universidade de São Paulo, Ribeirão Preto, 1997. 
TRIVIÑ̃̃S, A. N. S. Introdução ã pesquisa social em ciências sociais. São Paulo: Atlas, 1988. $145 \mathrm{p}$.

VALENTE, F. Saúde, Trabalho, Lazer, Prazer e vida. A Questão individual e o coletivo. Cadernos de nutriação, Florianópolis, n-1,1991. 21 p. (mimeografado).

VASCONCELOS, E. M.. Educação popular nos serviços de saúde. 3 ed. São Paulo: Hucitec, 1997. 167 p.

VELLOZO, V.; MARTINS, M. I. C.; NASCIMENTO, R. B. do. Articulando ensino e pesquisa: construindo uma proposta de capacitação para docentes do ensino técnico. Cadernos de Saúde Pública, Rio de Janeiro, v.15, p. 7-14, out. 1999. Suplemento 2.

ZÓCCHIO, Á. Prática de prevenção de acidentes: ABC da segurança do trabalho. 4 ed. São Paulo: Atlas, 1980. 186 p. 


\section{APÊNDICE}


ANEXOS 


\begin{abstract}
ANEXO A
UNIVERSIDADE DE SÃO PAULO- CAMPUS DE RIBEIRÃO PRETO

ROTEIROS DE OBSERVAÇÃO
\end{abstract}

1. EMPRESA

NOME DO SETOR:

NÚMERO DE FUNCIONÁRIOS:

TRABALHO EM TURNOS

TAREFAS DESEMPENHADAS:

CARGAS LABORAIS:

FISICAS

QUIMICAS

MECÂNICAS

FISIOLÓGICAS

PSICOLÓGICAS

USO DE EQUIPAMENTOS DE PROTEÇÃO INDIVIDUAL

EQUIPAMENTOS COLETIVOS

PRESENÇA DO SESMT NA EMPRESA

OUTRAS OBSERVAÇÕES 
2. REUNIÕES DA CIPA:

Formatados: Marcadores e

\author{
2. REUNIÖES DA CIPA:
}

NÚMERO DE PARTICIPANTES

SETOR DOS PARTICIPANTES

QUESTÕES ABORDADAS

SOLUÇÕES ENCONTRADAS

ATITUDES E POSTURAS DOS PARTICIPANTES

OUTRAS OBERVAÇÕES 


\begin{abstract}
ANEXO B
UNIVERSIDADE DE SÃO PAULO- CAMPUS DE RIBEIRÃO PRETO

QUESTIONÁRIO APLICADO AOS CIPEIROS
\end{abstract}

1. AMBIENTE E SESMT

O QUE VOCÊ ENTENDE POR RISCO OCUPACIONAL?

NO SEU AMBIENTE DE TRABALHO EXISTE ALGUM TIPO DE RISCO OCUPACIONAL? SE SIM, QUAIS CONSEGUE IDENTIFICAR.

VOCÊ CONHECE OS EQUIPAMENTOS DE PROTEÇÃO INDIVIDUAL? SE SIM, VOCÊ UTILIZA ALGUM DELES EM SEU AMBIENTE DE TRABALHO?

O QUE VOCÊ ENTENDE POR SESMT? QUAIS OS SERVIÇOS PRESTADOS PELO SESMT?

A EMPRESA TEM SESMT? VOCÊ UTILIZA SEUS SERVIÇOS? 
2. CIPA :

HÁ QUANTO TEMPO É MEMBRO DA CIPA?

O QUE VOCÊ ENTENDE POR CIPA?

TEM CONHECIMENTO DAS ATRIBUIÇÒES DA CIPA?

QUAL O SEU INTERESSE EM PARTICIPAR DA CIPA?

QUAIS AS ATIVIDADES QUE TEM DESENVOLVIDO JUNTO À CIPA?

TEM DESENVOLVIDO TODAS AS ATIVIDADES QUE GOSTARIA DE DESENVOLVER JUNTO À CIPA? SIM ( ) NÃO( )

SE NÃO, POR QUE NÃO?

COMO VOCÊ JULGA SUA PARTICIPAÇÃO?

COMO VOCÊ JULGA A PARTICIPAÇÃO DE SEUS COLEGAS?

PROBLEMAS ENFRENTADOS JUNTO À CIPA

SOLUÇÕES QUE VOCÊ SUGERE PARA OS PROBLEMAS DA CIPA

O QUE VOCÊ ENTENDE POR EDUCAÇÃO EM SAÚDE NOS AMBIENTES DE TRABALHO?

VOCÊ ACHA QUE A CIPA PODE TER AÇÕES DE EDUCAÇÃO EM SAÚDE NA EMPRESA? SE SIM, COMO?

E A SIPAT? QUAL A SUA FUNÇÃO?

COMO TÊM SIDO AS SIPATS, SUA GESTÃO NA CIPA?

GOSTARIA DE ESCREVER ALGO QUE NÃO QUESTIONADO? 


\section{ANEXO C}

\section{TERMO DE CONSENTIMENTO}

A presente pesquisa pretende compreender as ações de educação em saúde enquanto prática de promoção à saúde do trabalhador, transformadora da realidade concreta; para tanto necessita analisar os conteúdos da educação em saúde nos ambientes de trabalho.

Com a participação dos trabalhadores cipeiros, pretende-se através das entrevistas e questionários, atingir os objetivos propostos. Fica aqui garantido o sigilo das informações que forem fornecidas e usadas neste trabalho investigativo.

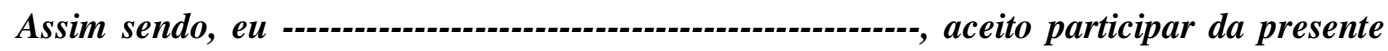
investigação que discutirá temas ligados à saúde do trabalhador, no ano de 2002, no município de Ribeirão Preto, SP, nas datas e horários combinados. Declaro estar ciente de que não haverá prejuízos físicos ou morais decorrentes de minha participação na pesquisa, e de que poderei, a qualquer momento, desistir desta participação, sem que isso traga conseqüiências negativas.

Ribeirão Preto, 10 de setembro de 2002.

Assinatura do participante

Assinatura da pesquisadora 


\section{ANEXO D}

\section{ATAS DAS REUNIÕES DA CIPA}

\section{ATA DA 1. ${ }^{a}$ REUNIÃO ORDINÁRIA DA C.I.P.A/2000 - MARCO}

\section{1 - ASSUNTOS NOVOS:}

O Sr. Presidente sugeriu a criação de um plano de ação envolvendo todos os integrantes da CIPA, objetivando a melhoria dos trabalhos em benefício da segurança e saúde dos funcionários, que foi aceito por todos os membros.

Assim sendo, foram criados três grupos de trabalho:

- Grupo Social: promover campanhas, treinamentos. Composto por 5 pessoas:

- Grupo Operacional: responsável pelas inspeções e controle dos riscos de acidentes. Composto por 5 pessoas:

- Grupo de Informação: abordando temas para informação aos funcionários. Composto por 5 pessoas

Os trabalhos a serem desenvolvidos neste mês são:

- Grupo de Informação: Alcoolismo

- Grupo Social: Reciclagem sobre as propostas da CIPA-2000;

- Grupo Operacional: Plano de ação junto aos riscos oferecidos.

\section{2- ACIDENTES OCORRIDOS:}

Ocorreram 03 acidentes, sendo 01 com afastamento de 15 dias e 02 sem afastamento. 


\section{ATA DA 2. ${ }^{a}$ REUNIÃO ORDINÁRIA DA C.I.P.A / 2000 -MAIO}

\section{1 - ASSUNTOS NOVOS:}

- Foi definido um plano de correção para prevenção de acidentes com o trânsito de empilhadeiras, onde serão instaladas lâmpadas, distribuídos folhetos e abordagens com orientações, e também será demarcada a área de trânsito de pessoas;

- Selecionado o programa para os grupos internos da CIPA durante o próximo mês;

- Foi sugerido a criação do mural da CIPA;

- Foi discutido uma ação de sensibilização dos funcionários, através de palestras internas.

\section{2 - ACIDENTES OCORRIDOS:}

Ocorreram 04 acidentes, sendo 01 com afastamento e 03 sem afastamento. 


\section{ATA DA 3. ${ }^{\text {a }}$ REUNIÃO ORDINÁRIA DA C.I.P.A / 2000 -AGOSTO}

\section{1 - ASSUNTOS NOVOS:}

- Todos os presentes foram alertados sobre as obrigações da CIPA;

- Foi comentado o alto número de acidentes ocorridos no $1 .^{\circ}$ semestre de 2000 e como reduzi-los;

- Foi discutido o horário de trabalho adotado por uma equipe da empresa e os riscos de acidentes ocasionados pelo seu excesso.

- Foi definido que os responsáveis por cada área será informado imediatamente sobre os acidentes ocorridos, para uma ação corretiva imediata;

- Será feito um plano de ação imediato de conscientização sobre os acidentes nos locais de maior risco;

- Estão sendo feitos, em cada área, treinamentos mensais sobre prevenção de acidentes, para sua redução.

\section{2 - ACIDENTES OCORRIDOS:}

- Fevereiro: $\quad 09$ sem afastamento e 01 com afastamento;

- Março: 02 sem afastamento e 01 com afastamento;

- Abril: $\quad 06$ sem afastamento;

- Maio: 04 sem afastamento e 01 acidente de trajeto;

- Junho: 02 sem afastamento, 02 com afastamento e 01 acidente de trajeto. 


\section{ATA DA 4. ${ }^{a}$ REUNIÃO ORDINÁRIA DA C.I.P.A /2000 - SETEMBRO}

\section{1 - ASSUNTOS NOVOS:}

- Foi solicitado o retorno do relatório de levantamento de riscos existentes, para que as ações sejam efetuadas com mais eficiência;

- Foi comentado sobre o programa de treinamento sobre a prevenção de acidentes realizado, e solicitado cooperação dos supervisores no agendamento e liberação dos funcionários pra continuidade e maior participação de todos;

- Está sendo realizado um trabalho em conjunto com um engenheiro, no intuito de levantar soluções práticas de melhorias no ambiente e nos equipamentos, para maior segurança do trabalhador;

- Foi levantada uma preocupação com o treinamento de primeiros socorros, para uma ação imediata em casos de acidentes, e também em horários onde não há a presença da enfermaria do trabalho;

- Foi solicitado que seja efetuado um treinamento com as pessoas que participam da auditoria do Programa de organização e limpeza, sobre segurança pessoal e dos locais auditados;

- Foram discutidos os riscos de acidentes levantados em inspeções realizadas na fábrica.

\section{2-ACIDENTES OCORRIDOS:}

- 14 acidentes sem afastamento;

- 02 acidentes com afastamento.

\section{3-ANEXOS:}

- Relatório de levantamento de riscos novos e pendentes. 


\section{ATA DA 5. ${ }^{a}$ REUNIÃO ORDINÁRIA DA C.I.P.A / 2000- OUTUBRO}

\section{1 - ASSUNTOS NOVOS:}

- Foram discutidos os temas e assuntos da SIPAT-2000, como o Alcoolismo, Meio Ambiente, Desperdício de Água, teatro sobre Prevenção de Acidentes no Trabalho;

- Foi sugerido uma SIPAT mais dinâmica, com apresentação dos temas de forma que possa atrair mais a atenção dos participantes, fixando e contribuindo melhor para o entendimento;

- Foi solicitado que todas as áreas da empresa participem da SIPAT, pois algumas têm uma baixa frequiência.

- Foram definidos três concursos com premiação para os funcionários, durante a SIPAT-2000, que são:

- Slogan para a SIPAT-2000;

- Idéias sobre Segurança no Trabalho;

- $\quad$ Exposição de cartazes na SIPAT-2000.

- Foram definidas competições em forma de gincana, para os funcionários e seus familiares, durante a SIPAT-2000;

- Haverá durante s SIPAT-2000, uma ginástica laboral de 05 minutos, todos os dias;

- Foi discutido o alto índice de acidentes com queimaduras ocorridos na fábrica, com sugestões de como evitá-los, como: identificação dos pontos de maior risco; mudança do uniforme e treinamento dos funcionários de uma área da empresa;

- Foi abordado o problema com os acidentes envolvendo os motoristas dos caminhões, onde serão efetuados treinamentos e orientações e também o correto uso de vestuário apropriado para o local.

\section{2- ACIDENTES OCORRIDOS:}

- 10 acidentes sem afastamento

- 3-ANEXOS: Relatório de levantamento de riscos novos e pendentes. 


\section{ATA DA 6. ${ }^{a}$ REUNIÃO ORDINÁRIA DA C.I.P.A / 2000 - NOVEMBRO}

\section{1 - ASSUNTOS NOVOS:}

- Foram discutidos os riscos pendentes e definida uma reunião extraordinária para levantamento de todos os riscos existentes na fábrica, para soluções rápidas;

- Foi sugerida a pintura uniforme dos locais para passagem de pedestres no interior do armazém da distribuição e fábrica, evitando dúvidas e acidentes;

- Foram discutidas as formas e premiações para as competições durante a SIPAT, visando atrair os funcionários a participarem dos eventos.

\section{2-ACIDENTES OCORRIDOS:}

- 02 acidentes sem afastamento e 02 acidentes com afastamento.

3 - ANEXOS:

- Relatório de levantamento de riscos novos e pendentes. 


\section{ATA DA 7. ${ }^{a}$ REUNIÃO ORDINÁRIA DA C.I.P.A/ 2000 - DEZEMBRO}

\section{1 - ASSUNTOS NOVOS:}

- Foi discutido sobre a comissão de eleição, definindo os preparativos para a realização da mesma;

- Foi sugerido a utilização de cinto de segurança acoplado a um cabo de aço para o pessoal responsável pelo enlonamento dos caminhões;

- Foi discutido a elaboração de um comunicado para as Transportadoras frisando o uso de vestimentas adequadas ao processo de carga e descarga dentro da empresa;

- Foi comentado que, em alguns dias do mês, há um excesso de caminhões dentro da fábrica para a descarga de Matéria Prima, gerando um trânsito e conduta de motoristas impróprios para a segurança;

- Foi discutido o problema com a higiene dos sanitários da fábrica em geral, principalmente o que atende ao pessoal do carregamento contratado pela Transportadora, sendo que foi entregue pela empresa em excelentes condições de uso, e não está havendo o trabalho de limpeza e conservação.

\section{2 - ACIDENTES OCORRIDOS:}

- 06 acidentes sem afastamento.

\section{3 - ANEXOS:}

- Relatório de levantamento de riscos e pendentes. 


\section{ATA DA 4. ${ }^{a}$ REUNIÃO DA CIPA REALIZADA EM 10 DE ABRIL DE 2001}

Dando abertura aos trabalhos, foi apresentada a pauta para a reunião, qual seja:

1 - Deu abertura a reunião expondo e comentando sobre o Programa de Controle Médico de Saúde Ocupacional. Explicando sobre a exposição aos riscos de cada cargo.

Obs.: /anexo, Programa de Controle.

2 - Comentou sobre a importância do exame de audiometria, que todo funcionário que se expõe a ruídos acima do permitido, tem que fazer o exame no prazo determinado pela legislação da Segurança do Trabalho.

\section{ATA DA 5. ${ }^{a}$ REUNIÃO DA CIPA REALIZADA EM 15 DE MAIO DE 2001}

Dando abertura aos trabalhos, foi apresentada a pauta para a reunião, qual seja:

1 - Comemoração pela conquista do novo recorde de 600.000 horas sem acidentes com afastamento;

2 - Discussão sobre o sorteio de prêmios para o pessoal participante da festa;

3 - Discussão de pendências gerais da CIPA.

Na próxima $5 .^{a}$ feira haverá distribuição de camisetas em comemoração à quebra do recorde de 252 dias, ou 600.000 horas, sem acidentes com afastamento.

Foi sugerido, pelos participantes da reunião, a nota meta de 1.000,000 (hum milhão) de horas sem acidentes com afastamento. O cálculo dessas horas leva em conta a somatória de todas as horas, de todos os funcionários, incluindo até mesmo todas as horas extras.

Foi sugerido também a confecção de uma placa comemorativa a este evento.

Para a festa, de todos os funcionários, foi acertado realizar-se um churrasco, dentro das dependências da empresa, no sábado, incluindo também a participação dos terceiros colaboradores mais freqüentes.Para a organização e realização desse churrasco, foram identificados alguns funcionários.Quanto à premiação, a diretoria liberou a verba de $\mathrm{R} \$ 800,00$ (oitocentos reais) para a compra dos brindes. O técnico de segurança ficou de verificar o que seria comprado com esse montante e ficou de verificar a publicação de matéria alusiva à comemoração em jornal da região.O grupo se comprometeu a acelerar a confecção dos quadros de risco junto à empresa de tipografia para tentar afixá-los até o próximo sábado. 


\section{ATA DA 7. ${ }^{a}$ REUNIÃO DA CIPA REALIZADA EM 17 DE JULHO DE 2001}

Iniciando a reunião, comentou sobre as pendências - Oportunidades de melhorias:

- Mapas de risco;

- Exaustor sanitário Matéria Prima;

- Isolamento sala caldeiras;

- Acidentes ocorridos

- Médica / Acidentes;

- Procedimentos.

2 - comentou sobre a área da caldeira ser restrita, procurar sinalizar a área.

3 - comentou sobre o pessoal terceirizado que andam fumando em qualquer lugar, e jogam restos de cigarro em qualquer lugar da fábrica.

4 - sugeriu que os chefes fizessem reunião com os subordinados para esclarecer a todos mais uma vez, as áreas específicas para fumantes.

\section{ATA DA $8^{\text {a }}$ REUNIÃO DA CIPA REALIZADA EM 14 DE AGOSTO DE 2001}

1 - O vice presidente abriu a reunião, dando abertura aos comentários.

2 - Funcionário comentou sobre uma área, que logo após a porta de entrada, havia um buraco e estava sem a faixa de proteção, que um acidente naquele local causaria danos irreparáveis.

3 - Outro funcionário comentou sobre um serviço que estava sendo feito pela manutenção que também estava sem as devidas observações, como placas, informando que estava em manutenção aquela área.

4 - Foi sugerido que poderia ser feita uma reciclagem com o pessoal de Manutenção e empreiteiras, sobre colocarem placas de advertência sobre qualquer trabalho que eles forem realizar, como também desligarem chaves elétricas dos motores etc. qualquer desleixo por parte dos funcionários, os mesmos seriam advertidos.

5 - O funcionário comentou sobre os quadros de Mapeamento de Riscos, que ainda não foram colocados nos devidos lugares da fábrica.

6 - O técnico de segurança exibiu um filme sobre Segurança Elétrica para todos os presentes; sugerindo em seguida, que apresentasse este filme para todos os funcionários da fábrica. 


\section{ATA DA 10. ${ }^{a}$ REUNIÃO DA CIPA REALIZADA EM 9 DE OUTUBRO DE 2001}

1 - Dando início a abertura da reunião comentou-se sobre a Semana da SIPAT. Foi estipulada a semana de 19 a 23 de Novembro/01. Foi sugerido pelos participantes os termos que seriam apresentados no decorrer da semana como: Ergonomia, Prevenção de acidentes, prevenção de incêndios/rotina etc.

2 - Foi salientado uma reciclagem com o pessoal da Brigada de incêndio nos dias 20 a 27/10; inclusive com a participação do pessoal de Manutenção e os novos funcionários.

3 - O técnico de segurança observou que o final desta gestão da CIPA se daria no dia 12/12/01, assim sendo o Edital de eleição teria que ser providenciado 60 dias antes do encerramento. Ficou acertado que teria que ser providenciada uma comissão interna para a próxima eleição da CIPA.

4 - Funcionário deu prosseguimento a reunião comentando sobre problemas nas empilhadeiras. Que os isolamentos térmicos, das mesmas, foram retirados e que está causando queimaduras nas pernas das empilhadeiristas.

Sem mais assuntos para serem tratados, foi dada por encerrada a reunião. 


\section{ATA DA 11. ${ }^{a}$ REUNIÃO DA CIPA REALIZADA EM 13 DE NOVEMBRO DE 2001}

1 - Dando início a abertura da reunião comentou-se sobre a Eleição da CIPA de 2002, que será realizada no próximo dia 19/11/01.

2 - Foi sugerido que o curso de "cipeiros" teria que ser administrado no período de 03 a $07 / 12 / 01$

3 - O técnico de segurança especificou que a posse dos novos "cipeiros", será no dia $12 / 12 / 01$.

4 - Foi comentado o acidente ocorrido por funcionário, que ao subir em um banco para jogar produto na rosca do equipamento, sofreu uma queda, tendo um torção em seu joelho direito. Foi sugerido que fosse feita uma plataforma grande, com escada perto deste equipamento, para que houvesse maior segurança nesta tarefa.

5 - Funcionário sugeriu também que poderia ser colocado um sistema de transporte pneumático portátil ou manual, para maior desempenho e segurança.

6 - O técnico de segurança comentou sobre um incidente ocorrido com um dos brigadistas que alertava o pessoal terceirizado no final de semana, sobre o uso correto dos EPI's, houve desrespeito do funcionário que fora alertado pelo Brigadista.

7 - Houve um comentário sugerindo que fosse feito um rodízio com os brigadistas; que não fosse chamado sempre o mesmo brigadista para trabalhar nos finais de semana para que este tipo de comportamento dos funcionários não houvesse, pois em muitas vezes há implicância da parte dos funcionários pelo mesmo brigadista estar chamando a atenção muitas vezes em seguida. Sendo que havendo este rodízio certamente eles acatariam mais este alerta.

8 - Foi comentado que na parte inferior dos silos tem virado depósito de sucatas e sanitárias de motoristas. Tem que tomar uma atitude urgente desativando e fechando está parte dos silos, deixando exclusivamente adentrar naquele setor as pessoas que lá trabalham. 


\section{ATA DA 12. ${ }^{a}$ REUNIÃO DA CIPA EM 11 DE DEZEMBRO DE 2001}

1 - O Técnico de Segurança do Trabalho, deu abertura à reunião comentando sobre o acidente do funcionário da empresa. Houve comentários sobre o acidente ocorrido, chegando-se à conclusão de que foi provocado devido a imprudência do próprio funcionário.

2 - Foi observado que o funcionário acidentado poderia ser convidado a participar da próxima reunião da CIPA, para explicar aos presentes, como o acidente ocorreu.

3 - Foi sugerido que se fizessem novas palestras, observando os riscos de acidentes com os novos funcionários contratados.

4 - Funcionário sugeriu a realização de palestras abordando os temas de segurança com a empresa terceirizada. Informou também que um primeiro programa de reciclagem está programado pra antes do final do ano .

5 - Funcionário ressaltou que para os trabalhos de manutenção, a serem realizados na parada entre os dias 24 e 31 de Dezembro, cada empreiteira prestadora de serviço, terá pelo menos um funcionário da empresa responsável.

6 - O técnico comentou sobre o princípio de incêndio no elevador. Foi colocada a sugestão de substituí-lo por um sistema de transporte pneumático. Foi estabelecida a pendência de se instalar uma janela de inspeção nos pontos críticos do elevador.

7 - Foi comentado sobre a necessidade de se instalar um aterramento ao chassis dos caminhões que fazem a descarga de grãos. Esse aterramento tem a finalidade de evitar a formação de faíscas elétricas devido a cargas estáticas no momento do descarregamento.

8 - Foi solicitado que verificasse as mangueiras e os extintores de incêndio, na laje dos silos e também na casa de máquinas do elevador de pessoas, bem como, estudar a possibilidade da instalação de mais extintores.

9 - O técnico fez um rápido comentário sobre o que denominou de "balanço anual" das atividades da CIPA.

10 - Todos os presentes fizeram comentários a respeito de sua própria participação na CIPA e também sobre o trabalho realizado durante a gestão que está se encerrando. 


\section{ATA DE REUNIÃO DA CIPA EM ABRIL DE 2002}

A abertura da reunião foi realizada pelo senhor presidente. Na ocasião, o senhor presidente se desculpou pela ausência na última reunião. Posteriormente, o Técnico de Segurança do Trabalho, informou aos "cipeiros", sobre os acidentes ocorridos .

1 - Sobre esta ocorrência, contactar o chefe da área técnica e verificar a possibilidade de adequação da esteira, a fim de se aumentar a segurança durante o funcionamento do equipamento.

2 - Realizar a troca do aparelho (termômetro) quebrado.

3 - Houve treinamento para os terceiros responsáveis pela montagem dos paletes. Também, informou que houve uma melhora significativa na montagem destes paletes.

Durante a reunião o técnico e o Auxiliar de Enfermagem da unidade, alertaram sobre a necessidade dos colaboradores realizarem o revezamento de funções em sua área de atuação, a fim de se evitar lesões por esforço repetitivo.

Dando continuidade, foi informado que de acordo com a Legislação, em cada local de armazenagem, deve ser estocado no máximo $135 \mathrm{~kg}$ de GPL e 200L de líquido inflamável, sendo a distância entre os pontos de armazenagem de no mínimo $15 \mathrm{~m}$.

Ao final da reunião, o senhor presidente colocou a palavra livre, o senhor comentou sobre o acionamento da válvula de alimentação (ocorrência já se encontra na lista de pendência), o qual ainda não foi arrumado, segundo o colaborador, os choques elétricos são freqüentes no equipamento, como ninguém mais fizesse uso da palavra, a reunião foi encerrada às nove horas.

A próxima reunião foi agendada para o dia quatorze de maio de dois mil e dois, no mesmo local e horário. 


\section{ATA DE REUNIÃO DA CIPA -MAIO 2002}

A abertura da reunião foi realizada e solicitado aos "cipeiros", o agendamento de nova auditoria para verificar a realização das ações corretivas relacionadas no relatório de controle de ações de melhoria. As datas das auditorias serão estabelecidas pelas equipes e terão a companhia do técnico de segurança.

Divisão das equipes:

Dando continuidade, foi informado que será realizado um relatório de faltas dos membros da CIPA, o qual será entregue à gerência.

Posteriormente, foram informados aos cipieiros os acidentes ocorridos no período.

Durante a reunião, foram relatados dois acidentes, também, ocorridos no período:

1 - Queda do duto do exaustor da secadora, causado pelo desgaste de equipamento (oxidação).

2 - quebra da correia do elevador, seguido de incêndio.

Os participantes da Brigada de incêndio foram citados pelo ótimo desempenho durante o incêndio. As causas do incidente serão averiguadas.

Ao final da reunião, o senhor vice presidente, questionou sobre as normas de segurança para o processo de desobstrução do silo de concreto, segundo o mesmo, nenhuma manobra será realizada sem a segurança necessária, como ninguém mais fizesse uso da palavra, encerrou a reunião às oito horas e quarenta e cinco minutos.

A próxima reunião foi agendada para o dia onze de junho de dois mil no mesmo local e horário. 


\section{ATA DE REUNIÃO DA CIPA - JUNHO 2002}

A abertura da reunião foi realizada pelo senhor presidente, o qual informou aos “cipeiros” sobre a entrada do novo Técnico de Segurança.

Aproveitando a ocasião o senhor presidente pediu que se apresentasse aos "cipeiros". Durante sua apresentação comentou que será feito muita propaganda sobre segurança e ressaltou a importância dos "cipeiros" neste processo. Posteriormente, solicitou que todos os “cipeiros" se apresentassem e que o questionassem em caso de dúvida.

Em relação às auditoria de segurança, será verificado a melhor maneira de darmos continuidade aos trabalhos.

Sobre as reuniões periódicas, para que estas transcorram regularmente, solicitou que:

1 - Os horários das reuniões devem ser respeitados. Os "cipeiros" deverão ser pontuais. As reuniões deverão ter a duração de 1 hora.

2 - Durante o período os "cipeiros" deverão anotar as reclamações e melhorias solicitadas pelos colaboradores de sua área, uma vez que a CIPA é composta por membros de todas as áreas da empresa. Estas informações deverão ser trazidas na reunião, para que sejam discutidas e os responsáveis pelas correções / melhorias designados.

3 - As atas das reuniões serão expostas nos painéis da empresa, para que todos os colaboradores fiquem cientes do andamento da CIPA.

Em seqüência, foi informado a todos os presentes que funcionário solicitou verbalmente seu desligamento da CIPA, devido ao seu afastamento da empresa.

Dando continuidade à reunião o técnico colocou a palavra para que todos os "cipeiros" presentes, pudessem comentar possíveis falhas/melhorias de seu setor: 
- câmara fria: falta de luvas na câmara fria e uniformes. Deficiência no retorno de uniformes da lavanderia. Devido a elaboração do novo logotipo da empresa, houve atrasos na entrega dos novos uniformes, assim como na compra de EPI's.

- Área externa: buraco próximo à rampa da área de ensaque, o qual quase causou um acidente com um operador de empilhadeira.

- Mistura: colocação de escada sob tubos, evitando o risco de queda do operador da área durante o trabalho. Solicitação da soldagem de corrimão da escada próxima à moenda.

- Linha: local inadequado para armazenamento do álcool.

- Caixa dágua: colocação de uma plataforma para entrada da caixa d'água.

O senhor presidente solicitou o auxílio na área de segurança no Centro de Distribuição, ficou acertado que serão realizadas visitas mensais do técnico de segurança no local e que os treinamentos da equipe de Brigada de incêndio tanto dos colaboradores da fábrica como do CD serão mensais.

Ao final da reunião, o senhor presidente, informou que será realizada no próximo dia trinta de julho às sete horas e trinta minutos na sala de reunião desta empresa, uma reunião extraordinária pra que seja traçado o Plano de Ação da CIPA com a listagem de todas as pendências e a citação dos responsáveis pela ações corretivas e de seus respectivos prazos. 


\section{ATA DA REUNIÃO DA CIPA - JULHO-2002}

A abertura da reunião foi realizada pelo vice-presidente, o qual solicitou a secretaria a leitura da ata da reunião anterior.

Em seguida o Técnico de Segurança, ressaltou sobre a falta de comprometimento dos “cipeiros", e pontualidade, número reduzido de "cipeiros" presentes nas reuniões.

Diálogos de Segurança : distribuiu a todos os presentes exemplares de alguns diálogos de segurança e explicou a todos a maneira de se apresentar aos colaboradores, lembrando que a quantidade de participantes devem ser registrados. Comentou-se que para cada assunto do diálogo serão realizados treinamentos com os "cipeiros" para que estes esteja bem treinados, para repassar seus conhecimentos aos demais colaboradores. Os primeiros diálogos a serem divulgados aos colaboradores serão sobre Incêndio e EPIs nos meses de agosto e setembro e o treinamento dos "cipeiros" foi agendado para o dia 21 de agosto (Quarta feira) às 7:30 horas na sala de treinamento.

Tomando a palavra funcionário questionou os “cipeiros” sobre o que é necessário para que os "cipeiros" tenham a consideração das pessoas da fabricação. Segundo opinião de outro funcionário é importante a presença do superior imediato durante as reuniões/diálogos.

Segundo informações dos "cipeiros" alguns colaboradores continuam não fazendo uso dos EPI's, foi sugerido que os nomes destes colaboradores sejam relatados e estes treinados sobre o uso de EPI's e questionou sobre a adoção de documento sobre as irregularidades de segurança constatadas na fábrica.

Dando continuidade a reunião o senhor presidente colocou a palavra livre para que todos os "cipeiros" presentes pudessem comentar falhas / melhorias de seu setor:

- Algumas empilhadeiras com ausência de extintores. 
- Excesso de botijões de gás no antigo estacionamento de empilhadeira.

- Câmara fria

Necessidade de uma mangueira de água na plataforma do moinho

Estrutura da plataforma abalada

Falta de luvas na câmara fria e uniformes.

Necessidade de EPI's para pessoal de terceiros que auxilia na descarga de congelados

- Moega: rampa muito escorregadia

Senhor presidente solicitou mais uma vez, o auxilio na área de segurança no envio de distribuição.

Ao final da reunião, o senhor presidente ressaltou que os trabalhos estão caminhando, visto que algumas pendências do mês anterior já foram realizadas, porém solicitou maior envolvimento de todos os "cipeiros".

A próxima reunião foi agendada para o dia dezesseis de setembro de dois mil e dois, no mesmo local e horário. 
ANEXO E

SIPATs 


\section{ANEXO F}

DIÁLOGOS DE SEGURANÇA 
ANEXOG

FOLHETOS DE SAÚDE 


\section{ANEXO H}

MAPA 


\section{ANEXO I}

\begin{tabular}{|c|c|}
\hline \multicolumn{2}{|r|}{ CIPA } \\
\hline RAZÕES & $\begin{array}{l}\text { "Ajudar a melhorar as condições de trabalho" (4). } \\
\text { "Meu interesse vem em } 1^{\circ} \text { - lugar, pela minha saúde e } \\
\text { proteção dentro da empresa e agir de modo a garantir a } \\
\text { segurança e informações de meus companheiros de } \\
\text { trabalho, à empresa e também à seus funcionários" (6). } \\
\text { "Aprender e passar algum conhecimento adquirido, durante } \\
\text { minha gestão" (7). }\end{array}$ \\
\hline PARTICIPAÇÃO & $\begin{array}{l}\text { "Um pouco tímida! Os participantes mais próximos dos } \\
\text { níveis operacionais, ainda se sentem constrangidos de se } \\
\text { afastarem de seus postos de trabalho, para participar das } \\
\text { reuniões. Todavia, em geral, } \\
\text { mostram-se motivados "(1). } \\
\text { "Devido às grandes mudanças atuais na empresa, a } \\
\text { participação da CIPA está sendo um pouco prejudicada " } \\
\text { (1). } \\
\text { "Com certeza, foram bem selecionadas e exercem suas } \\
\text { funções de boa forma e com responsabilidades. Os meus } \\
\text { colegas da empresa em si, são todos conscientes sobre a } \\
\text { segurança, garantindo um local de trabalho em boas } \\
\text { condições" (5). }\end{array}$ \\
\hline
\end{tabular}

CIPEIROS 


\begin{tabular}{|l|l|}
\hline \multicolumn{2}{|c|}{ Conceitos e A tribuições da CIPA } \\
\hline CONCEITO & $\begin{array}{l}\text { "CIPA é um grupo de pessoas responsáveis por difundirem a } \\
\text { segurança do trabalho e mostrar os prejuízos, tanto pessoais, quanto } \\
\text { para a empresa aos demais companheiros de trabalho" (9). }\end{array}$ \\
\hline ATRIBUIÇÕES & $\begin{array}{l}\text { "Tem como objetivo observar, relatar condições de risco nos } \\
\text { ambientes de trabalho, e solicitar medidas para reduzir até eliminar os } \\
\text { riscos existentes e/ou neutralizar os mesmos, discutir os acidentes } \\
\text { ocorridos encaminhando ao SESMT e ao empregador o resultado da } \\
\text { discussão, solicitando medidas que previnam acidentes semelhantes e, } \\
\text { ainda, orientar os demais, quanto à prevenção de acidentes" (1). } \\
\text { "A CIPA tem, como prerrogativas, promover a divulgação da } \\
\text { prevenção de acidente, utilizando, para isso, treinamentos e atividades } \\
\text { dinâmicas, reunem-se para discutir todos os assuntos relativos às } \\
\text { ocorrências de acidentes e apontar soluções, para se evitar que tais } \\
\text { acidentes se repitam. Também é o elo de comunicação entre os níveis } \\
\text { operacionais e a alta administração da empresa promover a segurança, } \\
\text { higiene e organização dos ambientes de trabalho" (3). } \\
\text { “Ajudar a melhorar as condições de trabalho com reuniões" (5). } \\
\text { "Tem como objetivo a prevenção de acidentes e doenças, decorrentes } \\
\text { do trabalho, de modo a tornar compatível, permanente o trabalho com } \\
\text { a preservação da vida e a promoção da saúde do trabalhador" (8). } \\
\text { "Questionar problemas da empresa e solucionar problemas, quanto à } \\
\text { saúde do trabalhador" (9). }\end{array}$ \\
\hline
\end{tabular}

QUADRO 1.2 . CONCEITO E AS ATRIBUIÇÕES DA CIPA, SEGUNDO OS CIPEIROS 


\begin{tabular}{|l|l|}
\hline \multicolumn{2}{|l|}{ TEMAS NAS REUNIÕES DA CIPA } \\
\hline ALCOOLISMO & ATA DE 2000 - MARÇO. \\
\hline TABAGISMO & $\begin{array}{l}\text { Nessa reunião, foi conversado sobre o hábito de fumar entre os } \\
\text { trabalhadores (Observação de 13-09-02) }\end{array}$ \\
\hline PRIMEIROS SOCORROS & ATA DE 2000- SETEMBRO. \\
\hline MEIO AMBIENTE & ATA DE 2000-OUTUBRO \\
\hline ÁGUA & ATA DE 2000-OUTUBRO \\
\hline PCMSO & ATA DE 2001-ABRIL \\
\hline PREPARO PARA UM & ATA DE 2001- MAIO \\
\hline MELHOR DESEMPENHO & \\
\hline ACIDENTESÇÃO & ABERDADO NO QUADRO 2. 2. \\
\hline
\end{tabular}

$\begin{array}{lllllllll}\text { QUADRO } & 2.1 . & \text { TEMAS } & \text { ABORDADOS } & \text { NAS } & \text { REUNIÕES } & \text { DE } & \text { CIPA } & \text { PARA }\end{array}$ DESENVOLVIMENTO EM ATIVIDADES EDUCATIVAS 


\begin{tabular}{|c|c|}
\hline \multicolumn{2}{|c|}{ PREVENÇÃO DE A CIDENTES } \\
\hline USO DE EPIs & $\begin{array}{l}\text { Falta de luvas na câmara fria, e uniformes. Deficiência no retorno de uniformes da } \\
\text { lavanderia. Devido à elaboração do novo logotipo da empresa, houve atrasos na entrega dos } \\
\text { novos uniformes, assim como na compra de EPI's (ATA DE JULHO 2002). } \\
\text { Segundo informações dos "cipeiros", alguns colaboradores continuam não fazendo uso dos } \\
\text { EPI's. Foi sugerido que os nomes destes colaboradores sejam relatados e estes treinados sobre } \\
\text { o uso de EPI's e questionou sobre a adoção de documento sobre as irregularidades de } \\
\text { segurança constatadas na fábrica (ATA DE AGOSTO 2002). }\end{array}$ \\
\hline PREVENÇÃO DE QUEIMADURAS & $\begin{array}{l}\text { Foi discutido o alto índice de acidentes com queimaduras ocorridos na fábrica, com sugestões } \\
\text { de como evitá-los, como: identificação dos pontos de maior risco; mudança do uniforme e } \\
\text { treinamento dos funcionários de uma área da empresa (ATA DE OUTUBRO 2000). } \\
\text { Funcionário deu prosseguimento à reunião comentando sobre problemas nas empilhadeiras. } \\
\text { Que os isolamentos térmicos, das mesmas, foram retirados e que está causando queimaduras } \\
\text { nas pernas das empilhadeiristas (ATA DE OUTUBRO 2001). }\end{array}$ \\
\hline PREVENÇÃO DE INCÊNDIO & $\begin{array}{l}\text { O técnico comentou o princípio de incêndio no elevador . Foi colocada a sugestão de } \\
\text { substituí-lo por um sistema de transporte pneumático. Foi estabelecida a pendência de se } \\
\text { instalar uma janela de inspeção nos pontos críticos do elevador (ATA DE DEZEMBRO } \\
2001 \text { ). }\end{array}$ \\
\hline SEGURANÇA ELÉTRICA & $\begin{array}{l}\text { O técnico de segurança exibiu um filme sobre Segurança Elétrica para todos os presentes; } \\
\text { sugerindo em seguida, que apresentasse este filme para todos os funcionários da fábrica } \\
\text { (ATA DE AGOSTO 2001). }\end{array}$ \\
\hline QUEDA DE ALTURA & $\begin{array}{l}\text { Foi comentado o acidente ocorrido por funcionário, que ao subir em um banco para jogar } \\
\text { produto na rosca do equipamento, sofreu uma queda, tendo um torção em seu joelho direito. } \\
\text { Foi sugerido que fosse feita uma plataforma grande, com escada perto desse equipamento, } \\
\text { para que houvesse maior segurança nesta tarefa (ATA DE NOVEMBRO 2001). } \\
\text { Foi sugerido a utilização de cinto de segurança acoplado a um cabo de aço para o pessoal } \\
\text { responsável pelo enlonamento dos caminhões (ATA DE DEZEMBRO 2000). }\end{array}$ \\
\hline ACIDENTES POR CAMINHÕES & $\begin{array}{l}\text { Foi abordado o problema com os acidentes envolvendo os motoristas dos caminhões, onde } \\
\text { serão efetuados treinamentos e orientações e também o correto uso de vestuário apropriado } \\
\text { para o local (ATA DE OUTUBRO 2000). } \\
\text { Foi comentado que, em alguns dias do mês, há um excesso de caminhões dentro da fábrica } \\
\text { para a descarga de Matéria Prima, gerando um trânsito e conduta de motoristas impróprios à } \\
\text { segurança (ATA DE DEZEMBRO 2000). }\end{array}$ \\
\hline $\begin{array}{l}\text { ORGANIZAÇÃO DO TRÂNSITO } \\
\text { DE EMPILHADEIRAS }\end{array}$ & $\begin{array}{l}\text { Foi definido um plano de correção, para prevenção de acidentes com o trânsito de } \\
\text { empilhadeiras, onde serão instaladas lâmpadas, distribuídos folhetos e abordagens com } \\
\text { orientações, e também será demarcada a área de trânsito de pessoas (ATA DE MAIO 2000). } \\
\text { Foi sugerida a pintura uniforme dos locais, para passagem de pedestres no interior da fábrica, } \\
\text { evitando dúvidas e acidentes (ATA DE NOVEMBRO 2000). }\end{array}$ \\
\hline $\begin{array}{l}\text { HIGIENE, ORGANIZAÇÃO } \\
\text { AMBIENTE DE TRABALHO }\end{array}$ & $\begin{array}{l}\text { Foi solicitado um treinamento com as pessoas que participam da auditoria do Programa de } \\
\text { organização e limpeza, sobre segurança pessoal e dos locais auditados (ATA SETEMBRO } \\
\text { DE 2000). } \\
\text { Foi discutido o problema com a higiene dos sanitários da fábrica em geral, principalmente o } \\
\text { que atende ao pessoal do carregamento contratado pela Transportadora, sendo que foi } \\
\text { entregue pela empresa em excelentes condições de uso, e não está havendo o trabalho de } \\
\text { limpeza e conservação (ATA DE DEZEMBRO 2000). }\end{array}$ \\
\hline PREVENIR LER-DORT & $\begin{array}{l}\text { Durante a reunião, o técnico e o auxiliar de enfermagem da unidade, alertaram e a } \\
\text { necessidade dos colaboradores realizarem o revezamento de funções em sua área de atuação, } \\
\text { a fim de se evitar lesões por esforço repetitivo (ATA DE ABRIL 2002). }\end{array}$ \\
\hline $\begin{array}{l}\text { PREVENIR } \\
\text { EXCESSOS } \\
\text { JORNADA DE TRABALHO } \\
\end{array}$ & $\begin{array}{l}\text { Foi discutido o horário de trabalho adotado por uma equipe da empresa, e os riscos de } \\
\text { acidentes, ocasionados pelo seu excesso (ATA DE AGOSTO 2000). }\end{array}$ \\
\hline
\end{tabular}

QUADRO 2.2. TEMA-PREVENÇÃO DE ACIDENTES 


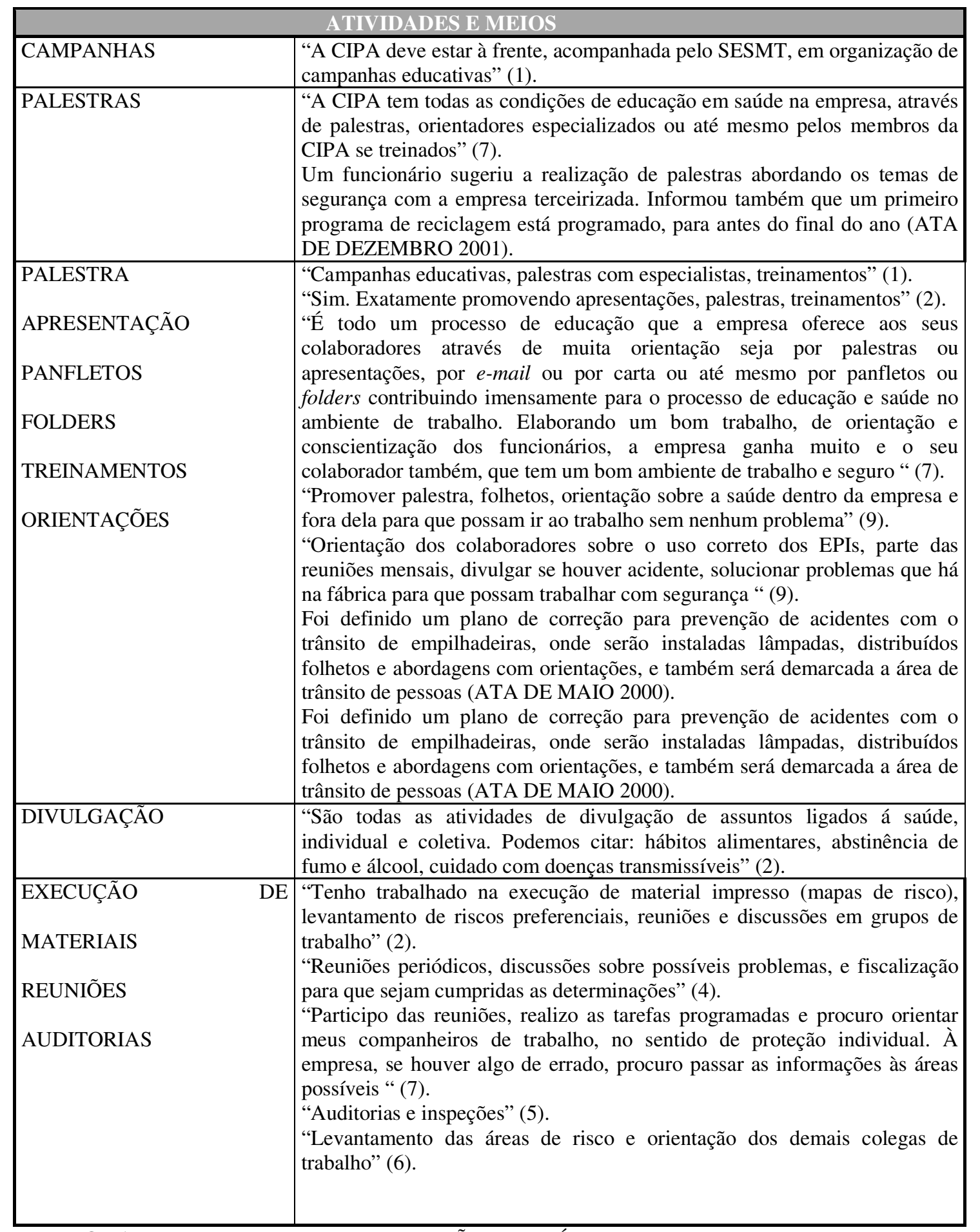

QUADRO 2.3. OS MEIOS EM EDUCAÇÃO EM SAÚDE, SEGUNDO OS CIPEIROS 


\begin{tabular}{|c|c|}
\hline \multicolumn{2}{|c|}{ PRÁTICAS/ATIVIDADES DE EDUCAÇÃO FORMAL } \\
\hline $\begin{array}{l}\text { CURSOS E TREINAMENTOS } \\
\text { PARA FUNCIONÁRIOS }\end{array}$ & $\begin{array}{l}\text { Problemas de informação dos funcionários, para melhorar isto, divulgação dos resultados } \\
\text { atingidos pela CIPA, aumentar os cursos de formação dos funcionários, cobrar mais o uso } \\
\text { dos EPIs (3). } \\
\text { Houve treinamento para os terceiros responsáveis pela montagem dos paletes. Também, } \\
\text { informou que houve uma melhora significativa na montagem destes paletes (ATA DE } \\
\text { ABRIL 2002). } \\
\text { Estão sendo feitos, em cada área, treinamentos mensais sobre prevenção de acidentes, para } \\
\text { sua redução (ATA DE AGOSTO 2000). }\end{array}$ \\
\hline $\begin{array}{l}\text { PALESTRAS DE SEGURANÇA } \\
\text { PARA FUNCIONÁRIOS }\end{array}$ & $\begin{array}{l}\text { Foi discutido uma ação de sensibilização dos funcionários, através de palestras internas (ATA } \\
\text { DE MAIO 2000). } \\
\text { Foi sugerido que se fizessem novas palestras, observando os riscos de acidentes com os novos } \\
\text { funcionários contratados (ATA DE DEZEMBRO 2001). } \\
\text { Funcionário sugeriu a realização de palestras abordando os temas de segurança com a } \\
\text { empresa terceirizada. Informou também que um primeiro programa de reciclagem está } \\
\text { programado para antes do final do ano (ATA DE DEZEMBRO 2001). }\end{array}$ \\
\hline PROGRAMAS DE RECICLAGEM & $\begin{array}{l}\text { Foi sugerido que poderia ser feita uma reciclagem com o pessoal de Manutenção e } \\
\text { empreiteiras, sobre colocarem placas de advertência sobre qualquer trabalho que eles forem } \\
\text { realizar, como também desligarem chaves elétricas dos motores etc. qualquer desleixo por } \\
\text { parte dos funcionários, os mesmos seriam advertidos (ATA DE AGOSTO 2001). } \\
\text { Foi salientado uma reciclagem com o pessoal da Brigada de incêndio nos dias } 20 \text { a 27/10; } \\
\text { inclusive com a participação do pessoal de Manutenção e os novos funcionários (ATA DE } \\
\text { OUTUBRO 2001). }\end{array}$ \\
\hline DIÁLOGOS DE SEGURANÇA & $\begin{array}{l}\text { Diálogos de Segurança : distribuiu a todos os presentes exemplares de alguns diálogos de } \\
\text { segurança e explicou a todos a maneira de se apresentar aos colaboradores, lembrando que a } \\
\text { Quantidade de participantes devem ser registrados. Comentou-se que para cada assunto do } \\
\text { diálogo serão realizados treinamentos com os "cipeiros" para que estes estejam bem } \\
\text { treinados, para repassar seus conhecimentos aos demais colaboradores. Os primeiros diálogos } \\
\text { a serem divulgados aos colaboradores serão sobre Incêndio e EPIs nos meses de agosto e } \\
\text { setembro e o treinamento dos "cipeiros" foi agendado para o dia } 21 \text { de agosto (Quarta feira) } \\
\text { às 7:30 horas na sala de treinamento (ATA DE AGOSTO 2002). }\end{array}$ \\
\hline FOLHETOS SOBRE SAÚDE & SÃO APRESENTADOS NO QUADRO 3.3. O SESMT NA ATIVIDADE EDUCATIVA \\
\hline
\end{tabular}

QUADRO 2. 4. PRÁTICAS/ATIVIDADES DE EDUCAÇÃO FORMAL 


\begin{tabular}{|c|c|}
\hline \multicolumn{2}{|r|}{ ATIVIDADES DE EDUCAÇÃO INFORMAL } \\
\hline VÍDEO & $\begin{array}{l}\text { O técnico de segurança exibiu um filme sobre Segurança Elétrica para todos os } \\
\text { presentes; sugerindo em seguida, que apresentasse este filme para todos os } \\
\text { funcionários da fábrica (ATA DE AGOSTO 2001). }\end{array}$ \\
\hline PROPAGANDA & $\begin{array}{l}\text { Durante sua apresentação, comentou que será feito muita propaganda sobre } \\
\text { segurança e ressaltou a importância dos "cipeiros" neste processo (ATA DE JULHO } \\
\text { 2002). }\end{array}$ \\
\hline MURAL DA CIPA & Foi sugerido a criação do mural da CIPA (ATA DE MAIO 2000). \\
\hline PAINÉIS & $\begin{array}{l}\text { As atas das reuniões serão expostas nos painéis da empresa, para que todos os } \\
\text { colaboradores fiquem cientes do andamento da CIPA (ATA DE JULHO 2002). }\end{array}$ \\
\hline PLACAS & $\begin{array}{l}\text { Outro funcionário comentou sobre um serviço que estava sendo feito pela } \\
\text { manutenção que também estava sem as devidas observações, como placas, } \\
\text { informando que estava em manutenção aquela área (ATA DE AGOSTO 2001). }\end{array}$ \\
\hline $\begin{array}{l}\text { COMUNICADO SOBRE } \\
\text { SEGURANÇA PARA } \\
\text { COLABORADORES }\end{array}$ & $\begin{array}{l}\text { Foi discutido a elaboração de um comunicado para as transportadoras frisando o uso } \\
\text { de vestimentas adequadas ao processo de carga e descarga dentro da empresa (ATA } \\
\text { DE DEZEMBRO 2000). }\end{array}$ \\
\hline $\begin{array}{l}\text { TRABALHO EM EQUIPE } \\
\text { MULTIPROFISSIONAL }\end{array}$ & $\begin{array}{l}\text { Está sendo realizado um trabalho, em conjunto com um engenheiro, no intuito de } \\
\text { levantar soluções práticas de melhorias no ambiente e nos equipamentos, para maior } \\
\text { segurança do trabalhador (ATA DE SETEMBRO 2000). }\end{array}$ \\
\hline SIPATs & $\begin{array}{l}\text { ESTE TEMA PELA SUA FREQÜÊNCIA E RELEVÂNCIA SERÁ ABORDADO } \\
\text { NO QUADRO 2.6. }\end{array}$ \\
\hline
\end{tabular}

QUADRO 2. 5. ATIVIDADES DE EDUCAÇÃO INFORMAL 


\begin{tabular}{|c|c|c|}
\hline \multicolumn{3}{|c|}{ SIPAT } \\
\hline \multicolumn{2}{|c|}{ TEMAS } & PALESTRANTES \\
\hline \multirow[t]{5}{*}{1998} & Acidentes do trabalho & $\begin{array}{l}\text { Grupo teatral contratado - peça sobre as } \\
\text { consequiências de um acidente do trabalho }\end{array}$ \\
\hline & Tabagismo & $\begin{array}{l}\text { Médico da divisão de medicina e segurança } \\
\text { do trabalho da prefeitura municipal }\end{array}$ \\
\hline & Drogas & $\begin{array}{l}\text { Representante da polícia militar do Estado } \\
\text { de São Paulo }\end{array}$ \\
\hline & Primeiros Socorros & $\begin{array}{l}\text { Representante do corpo de bombeiros - } \\
\text { grupamento de incêndios }\end{array}$ \\
\hline & DST-AIDS & Médico do trabalho \\
\hline \multirow{5}{*}{1999} & Saúde e Relaxamento & Enfermeira especializada em saúde mental \\
\hline & Cuidados corporais & Médica homeopata \\
\hline & Trabalho em equipe e cooperação & Professora de educação física \\
\hline & Meio ambiente & Ecólogo \\
\hline & DST- AIDS & Médico do trabalho \\
\hline \multirow[t]{4}{*}{2000} & Acidentes do trabalho & $\begin{array}{l}\text { Grupo teatral contratado - peça sobre as } \\
\text { consequiências de um acidente do trabalho } \\
\text { "Brincando com a vida" }\end{array}$ \\
\hline & Trabalho em equipe e cooperação & Professora de educação física \\
\hline & Valor do profissional dentro da empresa & Consultor de empresa de recursos humanos \\
\hline & DST- AIDS & Médico do trabalho \\
\hline \multirow[t]{4}{*}{2001} & Segurança no trabalho na empresa & Grupo de teatro da própria empresa - \\
\hline & Ergonomia & Grupo de fisioterapeutas ocupacionais \\
\hline & Prevenção de incêndios & $\begin{array}{l}\text { Representante do corpo de bombeiros - } \\
\text { grupamento de incêndios }\end{array}$ \\
\hline & DST- AIDS & Médico do trabalho \\
\hline
\end{tabular}

QUADRO 2. 6. SIPATS 


\begin{tabular}{|c|c|c|}
\hline QUESTÕES & PROBLEMAS & SOLUÇÕES \\
\hline $\begin{array}{l}\text { FALTA } \\
\text { COMPROMETIMEN-TO } \\
\text { JUNTO A } \quad \text { CIPA E DE } \\
\text { FREQUÊNCIA AS REUNIÕES }\end{array}$ & $\begin{array}{l}\text { Em seguida, o Técnico de Segurança, ressaltou a } \\
\text { falta de comprometimento dos "cipeiros", e } \\
\text { pontualidade, número reduzido de "cipeiros" } \\
\text { presentes nas reuniões (ATA DE AGOSTO 2002). }\end{array}$ & $\begin{array}{l}\text { Problemas de informação dos funcionários, para } \\
\text { melhorar isso, divulgação dos resultados } \\
\text { atingidos pela CIPA, aumentar os cursos de } \\
\text { formação dos funcionários, cobrar mais o uso } \\
\text { dos EPIs (3). }\end{array}$ \\
\hline $\begin{array}{l}\text { LIBERAÇÃO DOS } \\
\text { FUNCIONÁRIOS PARA } \\
\text { PARTICIPAÇÃO EM CURSOS } \\
\text { E TREINAMENTOS }\end{array}$ & $\begin{array}{l}\text { Foi comentado sobre o programa de treinamento } \\
\text { de a prevenção de acidentes realizado e solicitado } \\
\text { cooperação dos supervisores no agendamento e } \\
\text { liberação dos funcionários para continuidade e } \\
\text { maior participação de todo processo (ATA } \\
\text { SETEMBRO DE 2000). }\end{array}$ & $\begin{array}{l}\text { A empresa e sua diretoria não privilegiam as } \\
\text { ações da CIPA; assim as chefias estão mais } \\
\text { preocupadas com a produção (OBSERVAÇÃO } \\
\text { de 13-09-02) }\end{array}$ \\
\hline $\begin{array}{l}\text { FALTA DE ENVOLVIMENTO } \\
\text { POR PARTE DOS “CIPEIROS" }\end{array}$ & $\begin{array}{l}\text { Durante o período, os "cipeiros" deverão anotar as } \\
\text { reclamações e melhorias, solicitadas pelos } \\
\text { colaboradores de sua área, uma vez que a CIPA é } \\
\text { composta por membros de todas as áreas da } \\
\text { empresa (ATA DE JULHO 2002). } \\
\text { Ao final da reunião, o senhor presidente ressaltou } \\
\text { que os trabalhos estão caminhando, visto que } \\
\text { algumas pendências do mês anterior já foram } \\
\text { realizadas, porém solicitou maior envolvimento de } \\
\text { todos os "cipeiros" (ATA DE AGOSTO 2002). }\end{array}$ & $\begin{array}{l}\text { "A CIPA deveria receber mais atenção e deveria } \\
\text { ser tratada com mais apoio e seriedade pelas } \\
\text { chefias" (3). }\end{array}$ \\
\hline $\begin{array}{l}\text { FALTA DE INFORMAÇÃO } \\
\text { AOS FUNCIONÁRIOS }\end{array}$ & $\begin{array}{l}\text { Os funcionários não têm as informações básicas } \\
\text { sobre saúde e segurança (OBSERVAÇÃO de 30- } \\
10-02 \text { ) }\end{array}$ & $\begin{array}{l}\text { "Acredito que devemos elaborar em forte } \\
\text { trabalho de conscientização, junto aos } \\
\text { colaboradores. E fazer com que desperte em } \\
\text { cada colaborador ,um senso crítico e } \\
\text { participativo, com relação a sua integridade } \\
\text { física atrelada à um ganho na produtividade” (1). } \\
\text { "A solução dos problemas é aparente quando há } \\
\text { uma conscientização geral dos funcionários, em } \\
\text { relação à proteção individual e a conservação do } \\
\text { seu território de trabalho. Este conjunto traz } \\
\text { maior segurança para todos “ (7). } \\
\text { Houve treinamento para os terceiros } \\
\text { responsáveis pela montagem dos paletes. } \\
\text { Também, informou que houve uma melhora } \\
\text { significativa na montagem destes paletes (ATA } \\
\text { DE ABRIL 2002). }\end{array}$ \\
\hline & Precisamos tomar ações que agreguem maior & Segundo opinião de outro funcionário é \\
\hline
\end{tabular}




\begin{tabular}{|c|c|c|}
\hline $\begin{array}{l}\text { DESCRÉDITO POR PARTE } \\
\text { DOS TRABALHADORES NAS } \\
\text { AÇÕES DA CIPA }\end{array}$ & $\begin{array}{l}\text { credibilidade á CIPA. Hoje verificamos que a } \\
\text { maioria dos funcionários não acredita que a CIPA } \\
\text { "têm" poder de ação real (3). } \\
\text { Tomando a palavra funcionário questionou os } \\
\text { "cipeiros" sobre o que é necessário para que os } \\
\text { "cipeiros" tenham a consideração das pessoas da } \\
\text { fabrica (ATA DE AGOSTO 2002). }\end{array}$ & $\begin{array}{l}\text { importante a presença do superior imediato } \\
\text { durante as reuniões/diálogos (ATA DE } \\
\text { AGOSTO 2002). }\end{array}$ \\
\hline $\begin{array}{l}\text { LEVANTAMENTO } \\
\text { RISCOS }\end{array}$ & $\begin{array}{l}\text { Foi solicitado o retorno do relatório de } \\
\text { levantamento de riscos existentes, para que as } \\
\text { ações sejam efetuadas com mais eficiência (ATA } \\
\text { DE SETEMBRO 2000). } \\
\text { O funcionário comentou sobre os quadros de } \\
\text { Mapeamento de Riscos, que ainda não foram } \\
\text { colocados, nos devidos lugares da fábrica (ATA } \\
\text { DE AGOSTO 2001). }\end{array}$ & $\begin{array}{l}\text { Foram discutidos os riscos pendentes e definida } \\
\text { uma reunião extraordinária para levantamento de } \\
\text { todos os riscos existentes na fábrica, para } \\
\text { soluções rápidas (ATA DE NOVEMBRO 2000). } \\
\text { "Tenho trabalhado na execução de material } \\
\text { impresso (mapas de risco), levantamento de } \\
\text { riscos preferenciais, reuniões e discussões em } \\
\text { grupos de trabalho" (2). }\end{array}$ \\
\hline MURAL DA CIPA & $\begin{array}{l}\text { Foi sugerido a criação do mural da CIPA (ATA } \\
\text { DE MAIO 2000) }\end{array}$ & $\begin{array}{l}\text { Inexistência de um mural da CIPA contendo } \\
\text { informações sobre as reuniões e acidentes } \\
\text { ocorridos (OBSERVAÇÃO de 10-09-02) }\end{array}$ \\
\hline PLANO DE AÇÃO & $\begin{array}{l}\text { Falta de um plano de ação da CIPA, elaborado } \\
\text { segundo a NR-5 e as necessidades da empresa } \\
\text { (OBSERVAÇÃO de 23-06-02) }\end{array}$ & $\begin{array}{l}\text { "Minha sugestão é que um faça um grupo para } \\
\text { discussão das novas diretrizes e traçar os } \\
\text { objetivos claros da CIPA, traçando um plano } \\
\text { concreto, voltado principalmente para o resgate } \\
\text { da imagem da CIPA" (2). } \\
\text { O Sr. Presidente sugeriu a criação de um plano } \\
\text { de ação, envolvendo todos os integrantes da } \\
\text { CIPA, objetivando a melhoria dos trabalhos em } \\
\text { benefício da segurança e saúde dos funcionários, } \\
\text { que foi aceito por todos os membros (ATA DE } \\
\text { MARÇO 2000). } \\
\text { Ao final da reunião, o senhor presidente, } \\
\text { informou que será realizada, no próximo dia } \\
\text { trinta de julho às sete horas e trinta minutos, na } \\
\text { sala de reunião desta empresa, uma reunião } \\
\text { extraordinária para que seja traçado o Plano de } \\
\text { Ação da CIPA, com a listagem de todas as } \\
\text { pendências e a citação dos responsáveis pela } \\
\text { ações corretivas, e de seus respectivos prazos } \\
\text { (ATA DE JULHO 2002). }\end{array}$ \\
\hline
\end{tabular}

QUADRO 2.7. PROBLEMAS E SOLUÇÕES IDENTIFICADOS NA PRÁTICA EDUCATIVA 


\begin{tabular}{|c|c|}
\hline \multicolumn{2}{|c|}{ CONCEITOS BÁSICOS } \\
\hline RISCO OCUPACIONAL & $\begin{array}{l}\text { "Nesta unidade, existe risco ocupacional, com: ruído (audição), } \\
\text { poeiras (pulmonares) e vapor (queimaduras)" (1). } \\
\text { "Sim, no meu ambiente de trabalho há riscos. Posso citar por } \\
\text { exemplo, piso escorregadio, ruído elevado, calor intenso, tubulações } \\
\text { quentes, equipamentos em movimento." (3). } \\
\text { " Risco ocupacional: riscos existentes durante a execução do trabalho } \\
\text { ou na área de atuação, ex.: ruído, utilização de produtos químicos" } \\
\text { (2). } \\
\text { "Não há riscos ocupacionais em minha área de trabalho (escritório)" } \\
\text { (2). } \\
\text { "RO excesso de peso sacaria com mais de } 50 \mathrm{Kg"} \mathrm{(5).} \\
\text { "É todo serviço não executado corretamente pelo colaborador e sim } \\
\text { prejudicando a si mesmo e ao próximo" (9). }\end{array}$ \\
\hline SESMT & $\begin{array}{l}\text { "A minha empresa possui o SESMT. Utilizo os seus serviços assim } \\
\text { que necessário. Quando sofro algum acidente de trabalho, logo } \\
\text { procuro o SESMT, ou, quando estou indisposto no trabalho. Participo } \\
\text { de palestras e convenções, quando possui também "(8). } \\
\text { "Serviço especializado em Engenharia de Segurança e Medicina do } \\
\text { trabalho. Visa à proteção contra acidente na segurança, doenças } \\
\text { ocupacionais e à saúde de todos os colaboradores da empresa" (9). }\end{array}$ \\
\hline EPIs & $\begin{array}{l}\text { "Sim, conheço os EPIs. Quando entro nas áreas de segurança e } \\
\text { medicina do trabalho, utilizo protetor auricular e deverei utilizar } \\
\text { sapatos apropriados" (2). } \\
\text { "Sim, óculos de proteção, protetor de ouvido, luvas e botas de } \\
\text { borracha" (4). }\end{array}$ \\
\hline SIPAT s & $\begin{array}{l}\text { "Apresentação de palestras educativas, gincanas, apresentação teatral" } \\
\text { (1). } \\
\text { "Dar cursos e palestras aumentando o nosso conhecimento pela } \\
\text { segurança do trabalho" ( 4). } \\
\text { "A SIPAT é uma semana dedicada à orientação aos funcionários e } \\
\text { colaboradores de uma empresa. Nessa semana, é trabalhada a } \\
\text { conscientização de todos, em relação a doenças, prevenção de } \\
\text { acidentes e segurança no ambiente de trabalho “(9). }\end{array}$ \\
\hline
\end{tabular}

QUADRO 3. 1. CONCEITOS BÁSICOS SOBRE SAÚDE E SEGURANÇA 


\begin{tabular}{|c|c|c|c|}
\hline QUESTÕES & & PROBLEMAS & SOLUÇÕES \\
\hline LER-DORT & & $\begin{array}{l}\text { Durante a reunião, o técnico e o auxiliar de } \\
\text { enfermagem da unidade alertaram sobre a } \\
\text { necessidade dos colaboradores realizarem o } \\
\text { revezamento de funções em sua área de } \\
\text { atuação, a fim de se evitar lesões por } \\
\text { esforço repetitivo (ATA DE ABRIL 2002). }\end{array}$ & $\begin{array}{l}\text { Os "cipeiros" preocupam-se com LER, sabem } \\
\text { que o aumento da produção pode levá-los a } \\
\text { LER, porém, não reclamam, pois, têm medo de } \\
\text { serem dispensados, (Observação de 12-08-02). }\end{array}$ \\
\hline $\begin{array}{l}\text { MANUTENÇÃO } \\
\text { LIMPEZA }\end{array}$ & $\mathrm{E}$ & 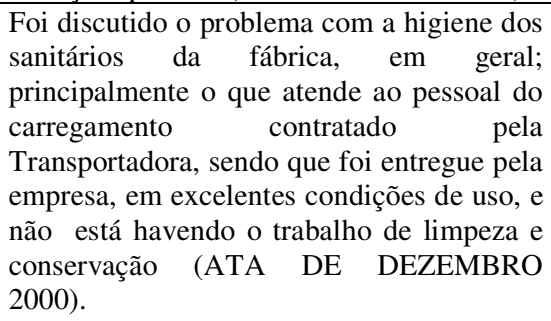 & $\begin{array}{l}\text { Excesso de botijões de gás, no antigo } \\
\text { estacionamento de empilhadeira (ATA DE } \\
\text { AGOSTO 2002). } \\
\text { Estrutura da plataforma abalada (ATA DE } \\
\text { AGOSTO 2002). } \\
\text { Realizar a troca do aparelho (termômetro) } \\
\text { quebrado (ATA DE ABRIL 2002). }\end{array}$ \\
\hline $\begin{array}{l}\text { ESTRUTURA- } \\
\text { BURACO NO PISO } \\
\text { ESCADA }\end{array}$ & & $\begin{array}{l}\text { Funcionário comentou sobre uma área, que } \\
\text { logo após a porta de entrada, havia um } \\
\text { buraco e estava sem a faixa de proteção, } \\
\text { que um acidente naquele local causaria } \\
\text { danos irreparáveis (ATA DE AGOSTO } \\
\text { 2001). } \\
\text { Buraco próximo à rampa da área de } \\
\text { ensaque, o qual quase causou um acidente } \\
\text { com um operador de empilhadeira (ATA } \\
\text { DE JULHO 2002). }\end{array}$ & $\begin{array}{l}\text { Funcionário sugeriu também que poderia ser } \\
\text { colocado um sistema de transporte pneumático } \\
\text { portátil ou manual, para maior desempenho e } \\
\text { segurança (ATA DE NOVEMBRO 2001). } \\
\text { Colocação de escada sob tubos, evitando o } \\
\text { risco de queda do operador da área, durante o } \\
\text { trabalho. Solicitação da soldagem de corrimão } \\
\text { da escada próxima à moenda (ATA DE } \\
\text { JULHO 2002). }\end{array}$ \\
\hline $\begin{array}{l}\text { EPC- } \\
\text { ATERRAMENTO } \\
\text { EXTINTORES } \\
\text { MANGUEIRAS }\end{array}$ & & $\begin{array}{l}\text { Foi solicitado que verificasse as mangueiras } \\
\text { e os extintores de incêndio, na laje dos silos } \\
\text { e também na casa de máquinas do elevador } \\
\text { de pessoas, bem como estudar a } \\
\text { possibilidade da instalação de mais } \\
\text { extintores (ATA DE DEZEMBRO 2001). } \\
\text { Algumas empilhadeiras com ausência de } \\
\text { extintores (ATA DE AGOSTO 2002). }\end{array}$ & $\begin{array}{l}\text { Necessidade de uma mangueira de água na } \\
\text { plataforma do moinho (ATA DE AGOSTO } \\
\text { 2002). }\end{array}$ \\
\hline EPI & & $\begin{array}{l}\text { Falta de luvas na câmara fria e uniformes } \\
\text { (ATA DE AGOSTO 2002). } \\
\text { Necessidade de EPI's para o pessoal de } \\
\text { terceiros que auxilia na descarga de } \\
\text { congelados (ATA DE AGOSTO 2002). }\end{array}$ & $\begin{array}{l}\text { Problemas de informação dos funcionários, } \\
\text { para melhorar isto, divulgação dos resultados } \\
\text { atingidos pela CIPA, aumentar os cursos de } \\
\text { formação dos funcionários, cobrar mais o uso } \\
\text { dos EPIs (3). }\end{array}$ \\
\hline
\end{tabular}

QUADRO 3.2. PROBLEMAS E SOLUÇÕES IDENTIFICADOS NO COTIDIANO DA

FÁBRICA 


\begin{tabular}{|c|c|}
\hline \multicolumn{2}{|c|}{ SESMIT NA ATIVIDADE EDUCATIVA } \\
\hline TEMAS & CONTEÚDOS \\
\hline STRESS & Aborda a questão do stress, causas e prevenção. \\
\hline $\mathrm{DM}$ & $\begin{array}{l}\text { Aborda o diabetes mellitus, conceito, causas, exames de detecção e } \\
\text { prevenção. }\end{array}$ \\
\hline HAS & Aborda a hipertensão arterial, o que é, causas e prevenção. \\
\hline AIDS & $\begin{array}{l}\text { Aborda a questão da AIDS nos dias atuais, fatores causais e formas de } \\
\text { prevenção. }\end{array}$ \\
\hline DENGUE & Aborda a prevenção da dengue. \\
\hline HÁBITOS ALIMENTARES & Aborda alimentação saudável e suas conseqüências. \\
\hline TABAGISMO & Aborda a questão do tabagismo, alertando para suas consequências. \\
\hline ALCOOLISMO & Aborda a questão do alcoolismo, alertando para suas consequências. \\
\hline AUTO-MEDICAÇÃO & Aborda os cuidados com a auto-medicação. \\
\hline VACINAÇÃO & Aborda as principais vacinas e calendário vacinal. \\
\hline $\begin{array}{l}\text { PREVENÇÃO AO CÂNCER } \\
\text { DE PRÓSTATA }\end{array}$ & $\begin{array}{l}\text { Aborda a questão do câncer de próstata nos dias atuais, fatores causais e } \\
\text { formas de detecção precoce e prevenção. }\end{array}$ \\
\hline $\begin{array}{l}\text { PREVENÇÃO AO CÂNCER } \\
\text { DE MAMA }\end{array}$ & $\begin{array}{l}\text { Aborda a questão do câncer de mama nos dias atuais, fatores causais e } \\
\text { formas de detecção precoce e prevenção. }\end{array}$ \\
\hline
\end{tabular}

QUADRO 3.3. SESMT NA ATIVIDADE EDUCATIVA 


\section{RESPOSTAS DOS CIPEIROS}

Risco oriundo de uma determinada atividade profissional.

Risco ocupacional: riscos existentes durante a execução do trabalho ou na área de atuação, ex.: ruído, utilização de produtos químicos.

RO é todo o risco de acidente ou dano à saúde, possível de ocorrer no ambiente de trabalho e durante as atividades profissionais.

Situações de riscos que o funcionário está exposto em sua função.

$\mathrm{RO}$ excesso de peso sacaria com mais de $50 \mathrm{Kg}$.

Ocorre quando na função que exercemos existe um perigo de algum acidente a curto ou a

longo prazo, devido a esforço desnecessário, força mal empregada ou equipamento mal projetado ou em situação de risco.

RO, é o risco de ocorrer "acidente" no desempenho do seu trabalho.

RO é todo o ambiente de trabalho que envolve um profissional que oferece insegurança, e não torna compatível o trabalho com a preservação da vida e a saúde do trabalhador.

É todo serviço não executado corretamente pelo colaborador e sim prejudicando a si mesmo e ao próximo.

2.No seu ambiente de trabalho existe algum tipo de risco ocupacional se sim, quais consegue

identificar:

Nesta unidade existe risco ocupacional, são: ruído (audição), poeiras (pulmonares) e vapor (queimaduras).

Não há riscos ocupacionais em minha área de trabalho (escritório).

Sim, no meu ambiente de trabalho há riscos. Posso citar por exemplo, piso escorregadio, ruído elevado, calor intenso, tubulações quentes, equipamentos em movimento, etc.

Contato diário com produtos químicos como "brevoxim", "topax", "gamamox" e risco ergonômico.

Piso escorregadio.

Sim, lido com produtos químicos e também há o risco ergonômico.

No meu ambiente de trabalho posso apontar alguns riscos ocupacionais que não são de tanta periculosidade, tais como, tomadas soltas, lâmpadas queimadas, ruídos constantes de reatores de lâmpadas.

Vários, não executar todo tipo de manutenção ou limpeza em máquina em movimento, o uso de ar comprimido do pessoal de descarga para limpeza do próprio corpo que é prejudicial a saúde, passar ar nas máquinas sem óculos de proteção.

3.Você conhece os equipamentos de proteção individual (EPIs) se sim, você utiliza algum deles em seu ambiente de trabalho?

Equipamento de Proteção individual é o equipamento utilizado individualmente pelo trabalhador para sua proteção individual EPI utilizado: Protetor auricular, sapatão.

Sim, conheço os EPIs. Quando entro nas áreas de segurança e medicina do trabalho utilizo protetor auricular e deverei utilizar sapatos apropriados.

Sim. Utilizo protetor auricular, avental e calçados apropriados. 
Sim, óculos de proteção, protetor de ouvido, luvas e botas de borracha.

Sim. Óculos, luvas, botina, protetor auricular, máscara.

Equipamento de proteção. Protetor, máscara e óculos.

Sim, utilizo protetor auricular, bota, óculos, etc...

Conheço os EPIs que a empresa oferece e procuro sempre utilizar nos locais indicados, tal como o departamento de produção e manutenção.

Sim: botas, luvas, óculos, protetor auditivo, máscara, capa, etc..

4.O que você entende por SESMT? Quais os serviços prestados pelo SESMT?

SESMT: Formado por profissionais especializados com a finalidade de promover a saúde e proteger a integridade do trabalhador no local de trabalho. Serviços prestados: O dimensionamento do SESMT vincula-se à gradação do risco de atividade principal e o número total de empregados conforme NR-4. O nosso é composto por médico com atendimento médico duas vezes por semana e a promoção e elaboração do PCMSO. Um auxiliar de enfermagem com atendimento diário de 8 horas diárias em pequenos acidentes e/ou encaminhamento ao médico e um técnico de segurança do trabalho.

SESMT: Abrange as áreas de segurança e medicina do trabalho e os serviços prestados por ele são na área de segurança e medicina do trabalho.

SESMT: É o serviço especializado de segurança e medicina do trabalho, suas atividades estão voltadas para a segurança das pessoas e do patrimônio ativo fixo da companhia, no que se refere aos aspectos operacionais e ambientais, promovendo a integridade da saúde como um todo. Para isso, promove treinamentos internos e organiza a CIPA e a brigada de incêndio.

Serviço especializado em segurança e medicina do trabalho, cuida da área de segurança e saúde.

Serviço de engenharia e medicina do trabalho é um órgão destinado a segurança do trabalhador.

SESMT: Serviço de engenharia e medicina do trabalho, atua em engenharia e medicina.

SESMT, órgão dentro da empresa que ainda para o trabalhador tenha informações e cuidado no tocante à segurança do trabalho e saúde, tanto dentro da empresa quanto fora.

O SESMT são os serviços especializados em Engenharia de Segurança e em Medicina do Trabalho. Tem a finalidade de promover a saúde e proteger $\mathrm{s}$ integridade do trabalhador no local de trabalho.

Serviço especializado em Engenharia de Segurança e Medicina do trabalho. Visa a proteção contra acidente na segurança, doenças ocupacionais e a saúde de todos os colaboradores da empresa.

\section{A empresa tem SESMT? Você utiliza seus serviços?}

A empresa tem SESMT e o mesmo é utilizado por todos os colaboradores.

Sim, minha empresa tem SESMT e utilizo seus serviços sempre que necessário.

A empresa tem SESMT e todos nós utilizamos seus serviços, por meio de seus comunicados, seus treinamentos, orientações, assistência ambulatorial e coordenação das atividades da CIPA e de brigada de incêndio.

Tem e eu utilizo.

Sim.

Tem e sim.

Sim, eu utilizo quando vou à enfermaria, quando recebo orientações sobre segurança. 
A minha empresa possui o SESMT. Utilizo os seus serviços assim que necessário. Quando sofro algum acidente de trabalho, logo procuro o SESMT, ou quando estou indisposto no trabalho. Participo de palestras e convenções quando possui também.

Sim, eu faço parte do SESMT, sou auxiliar de enfermagem de trabalho.

\section{Há quanto tempo é membro da CIPA?}

Formatados: Marcadores e numeração

Estamos iniciando um trabalho junto a CIPA, portanto não tenho histórico anterior para estar respondendo as outras questões.

07 meses.

Nesta empresa há 3 anos como membro indicado. Em outras empresas, por um período de 4 anos, também como indicado.

08 meses.

06 meses.

06 meses.

02 anos.

06 meses.

06 meses.

Formatados: Marcadores e

7 O que você entende por CIPA?

CIPA: Comissão interna de Prevenção de Acidentes, constitui por representantes dos empregados e do empregador.

CIPA é a Comissão interna de Prevenção de Acidentes.

CIPA é a Comissão interna de Prevenção de Acidentes.

CIPA é a Comissão interna de Prevenção de Acidentes.

CIPA é a Comissão interna de Prevenção de Acidentes.

CIPA é a Comissão interna de Prevenção de Acidentes.

CIPA é a Comissão interna de Prevenção de Acidentes.

CIPA é um grupo de pessoas responsáveis por difundirem a segurança do trabalho e mostrar os prejuízos tanto pessoal quanto para a empresa aos demais companheiros de trabalho.

8.Tem conhecimento das atribuições da CIPA?

Formatados: Marcadores e

numeração

Tem como objetivo observar e relatar condições de risco nos ambientes de trabalho e solicitar medidas para reduzir até eliminar os riscos existentes e/ou neutralizar os mesmos, discutir os acidentes ocorridos encaminhando ao SESMT e ao empregador o resultado da discussão, solicitando medidas que previnam acidentes semelhantes e, ainda, orientar os demais quanto à prevenção de acidentes.

A CIPA deve auxiliar o departamento de segurança à fim de garantir a integridade física e mental do funcionário.

A CIPA tem como prerrogativas promover a divulgação da prevenção de acidente, utilizando para isso treinamentos e atividades dinâmicas, reuni-se para discutir todos os assuntos relativos às ocorrências de acidentes e apontar soluções para se evitar que tais acidentes se repitam, também é o elo de comunicação entre os níveis operacionais e a alta administração da empresa para promover a segurança, higiene e organização dos ambientes de trabalho.

Fiscalizar e opinar sobre a segurança do funcionário.

Ajudar a melhorar as condições de trabalho com reuniões.

Orientar e fiscalizar. 
Orientar e cuidar da segurança dos seus companheiros de trabalhar, buscando melhorias e solução para problemas ligadas a segurança do trabalho.

Tem como objetivo a prevenção de acidentes e doenças decorrentes do trabalho, de modo a tornar compatível permanente o trabalho com a preservação da vida e a promoção da saúde do trabalhador.

Questionar problemas da empresa e solucionar problemas quanto á de saúde do trabalhador.

9.Qual o seu interesse em participar da CIPA?

Formatados: Marcadores e

numeração

Está em auxiliar junto aos demais cipeiros à manter a integridade dos funcionários.

Total!

Buscar conhecimento da segurança e aconselhar os colegas de serviço quando estão em perigo.

Ajudar a melhorar as condições de trabalho.

Contribuir.

Meu interesse vem em $1^{\circ}$ - lugar, pela minha saúde e proteção dentro da empresa e agir de modo a garantir a segurança e informações de meus companheiros de trabalho, à empresa e também à seus funcionários.

Aprender a passar algum conhecimento adquirido durante minha gestão.

10.Quais as atividades tem desenvolvido junto a CIPA?

Formatados: Marcadores e

numeração

Realização de auditorias de segurança nas áreas de fabricação estoque.

Tenho trabalhado na execução de material impresso (mapas de risco), levantamento de riscos preferenciais, reuniões e discussões em grupos de trabalho.

Participo de todas as reuniões e discutimos mais segurança que precisamos obter.

Reuniões periódicos, discussões sobre possíveis problemas, e fiscalização para que sejam cumpridas as determinações.

Auditorias e inspeções.

Levantamento das áreas de risco e orientação dos demais colegas de trabalho.

Participo das reuniões, realizo as tarefas programadas e procuro orientar meus companheiros de trabalho no sentido de proteção individual. À empresa, se houver algo de errado procuro passar as informações às áreas possíveis.

Orientação dos colaboradores sobre o uso correto dos EPIs, parte das reuniões mensais, divulgar se houver acidente, solucionar problemas que há na fábrica para que possam trabalhar com segurança.

11- Tem desenvolvido todas as atividades que gostaria de desenvolver junto à CIPA? Sim ( ) Não ( ), se não, por que não.

Devido as grandes mudanças atuais na empresa, a participação da CIPA está sendo um pouco prejudicada.

Foram feitas algumas sugestões mas ainda não foram atendidas porque ainda não houve tempo.

Não, porque algumas atividades esbarram na burocracia da empresa.

Não, algumas coisas ficam pendentes de uma gestão para outra e não são solucionadas, gostaria de resolver as pendências.

12- Como Julga sua participação? 
Um pouco prejudicada!

Minha participação hoje é muito pouca. Temos mais atividades do que podemos efetivamente resolver. Gostaria de participar mais.

Participo de todas as reuniões.

Minha participação é média, poderia ser melhor.

Boa.

Participação atuante, falta somente tempo para melhorar mais.

Eu julgaria minha participação como boa, é claro que se eu tivesse mais oportunidades, poderia render mais a favor da empresa, as normas de segurança da empresa são informar algo de errado que pode estar acontecendo.

Acredito que minha participação está sendo útil para o grupo e também para a empresa.

13- Como julga a participação de seus colegas?

Dos que participam das reuniões é satisfatória.

Um pouco tímida! Os participantes mais próximos dos níveis operacionais ainda se sentem constrangidos de se afastarem de seus postos de trabalho para participar das reuniões. Todavia, em geral, mostram-se motivados.

Muito importante!

Poderia ser melhor!

Todos têm se empenhado para o bom andamento das atividades dentro da CIPA.

Com certeza foram bem selecionadas e exercem suas funções de boa forma e com responsabilidades. Os meus colegas da empresa em si são todos conscientes sobre a segurança para possuir um local de trabalho em boas condições.

Ótima, trazem problemas e procuram resolver sempre os problemas que são levadas à reunião mensal.

\section{4- Problemas enfrentados junto à CIPA}

15- Soluções que você sugere para resolver:

Nenhum

Precisamos tomar ações que agreguem maior credibilidade á CIPA. Hoje verificamos que a maioria dos funcionários não acredita que a CIPA têm poder de ação real.

Problemas de informação dos funcionários, para melhorar isto, divulgação dos resultados atingidos pela CIPA, aumentar os cursos de formação dos funcionários, cobrar mais o uso dos EPIs...

Penso que há o não cumprimento das solicitações, para resolver sugiro mais informações e treinamento.

Nada.

Os problemas são os de rotina, manutenção de locais limpos, as vezes um acidente de trabalho, por falta de atenção, mas enfim todos unidos, conseguiremos alcançar nossos objetivos e os objetivos da empresa. A solução dos problemas é aparente quando há uma conscientização geral dos funcionários em relação à proteção individual e a conservação do seu território de trabalho. Este conjunto traz maior segurança para todos.

É difícil, porque problemas existem, mas soluções têm sérias conseqüências como por exemplo: "Feita a reunião, depois é feito um relatório e passado para a diretoria e esta passa para o encarregado de cada setor e o faz"... 
16- O que você entende por educação em saúde nos ambientes de trabalho?

Campanhas educativas, palestras com especialistas, treinamentos.

São todos as atividades de divulgação de assuntos ligados á saúde individual e coletiva. Podemos citar: hábitos alimentares, abstinência de fumo e álcool, cuidado com doenças transmissíveis, etc.

É quando se segue as normas de trabalho e se adquire uma boa formação e também a melhoria da nossa saúde.

Uso dos EPIs corretamente.

É a forma mais direta de instruir os funcionários para que se partem bem no processo de higiene e limpeza, e também com seus hábitos de serviço.

É um turno no qual dou muita importância, pois todo o conhecimento passado não é utilizado simplesmente na empresa e sim em casa, na rua, etc...

É todo um processo de educação que a empresa oferece aos seus colaboradores através de muita orientação seja por palestras ou apresentações, por e-mail ou por carta ou até mesmo por panfletos ou folders contribuindo imensamente para o processo de educação e saúde no ambiente de trabalho. Elaborando um bom trabalho de orientação e conscientização dos funcionários, a empresa ganha muito e o seu colaborador também, que tem um bom ambiente de trabalho e seguro.

Participar do SESMT, equipe de saúde. Promover palestra, folhetos, orientação sobre a saúde dentro da empresa e fora dela para que possam i ao trabalho sem nenhum problema.

17- Você acha que a CIPA pode ter ações de educação em saúde na empresa? Se sim, como?

A CIPA deve estar a frente acompanhada pelo SESMT em organização de campanhas educativas.

Sim. Exatamente promovendo apresentações, palestras, treinamentos.

Como? Dando curso e palestras a respeito do assunto.

Orientando e treinando.

Sim, pedindo maior orientação dos funcionários junto às chefias e fiscalizando.

Sim, fazendo campanhas, através de palestras.

A CIPA tem todas as condições de educação em saúde na empresa através de palestras, orientadores especializados ou até mesmo pelos membros da CIPA se treinados.

Sim, na orientação e participação junto a equipe de saúde na empresa.

18- E a SIPAT? Qual a sua função?

Apresentação de palestras educativas, gincanas, apresentação teatral.

Difundir a CIPA e as ações de segurança do trabalho para todos os colaboradores.

Reavivar todos os conceitos passados sobre a segurança e saúde ocupacional.

Dar cursos e palestras aumentando o nosso conhecimento pela segurança do trabalho.

Orientar e instruir os funcionários.

SIPAT tem a função de fortalecer os trabalhos da CIPA e do SESMT através de eventos no qual se recorde tudo sobre segurança do trabalho e saúde.

A SIPAT é uma semana dedicada à orientação aos funcionários e colaboradores de uma empresa. Nesta semana é trabalhada a conscientização de todos em relação à doenças, prevenção de acidentes e segurança no ambiente d trabalho.

19 - Como têm acontecido as SIPATs em sua gestão na CIPA? 
Não houve ainda SIPAT em minha gestão, ocorre no $2^{\circ}$ semestre do ano.

As SIPATs realizadas tem sido pouco expressivas, a grande maioria que comparecem o faz para "cumprir tabela."

As SIPATs costumam ser bem educativas e "animadas". São promovidas palestras, teatros e são bem aceitas por todos e ajudam muito na prevenção de acidentes do trabalho.

20 - Gostaria de escrever algo que não questionado?

Acredito que devemos elaborar em forte trabalho de conscientização junto aos colaboradores. E fazer com que desperte em cada colaborador um senso crítico e participativo com relação a sua integridade física atrelada à um ganho na produtividade.

Minha sugestão é que um faça um grupo para discussão das novas diretrizes e traçar os objetivos claros da CIPA, traçando um plano concreto, voltado principalmente para o resgate da imagem da CIPA.

A CIPA deveria receber mais atenção e deve ser tratado com mais apoio e seriedade pelas chefias.

Todas as questões são bem aceitas e são importantes no sentido de avaliar a CIPA e os "cipeiros", pois o início deste trabalho de prevenção de acidentes parte deles, outros questionários serão bem vindos.

Agradeço a oportunidade de participar desta pesquisa. 
GERENCIAMENTO DA SEGURANÇA E SAÚDE NO TRABALHO

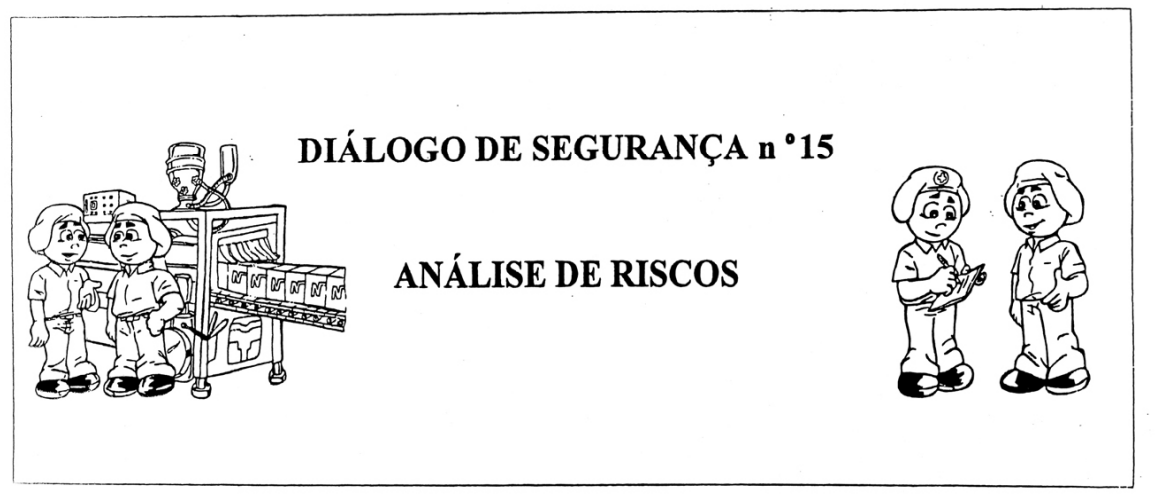

ANEXO E

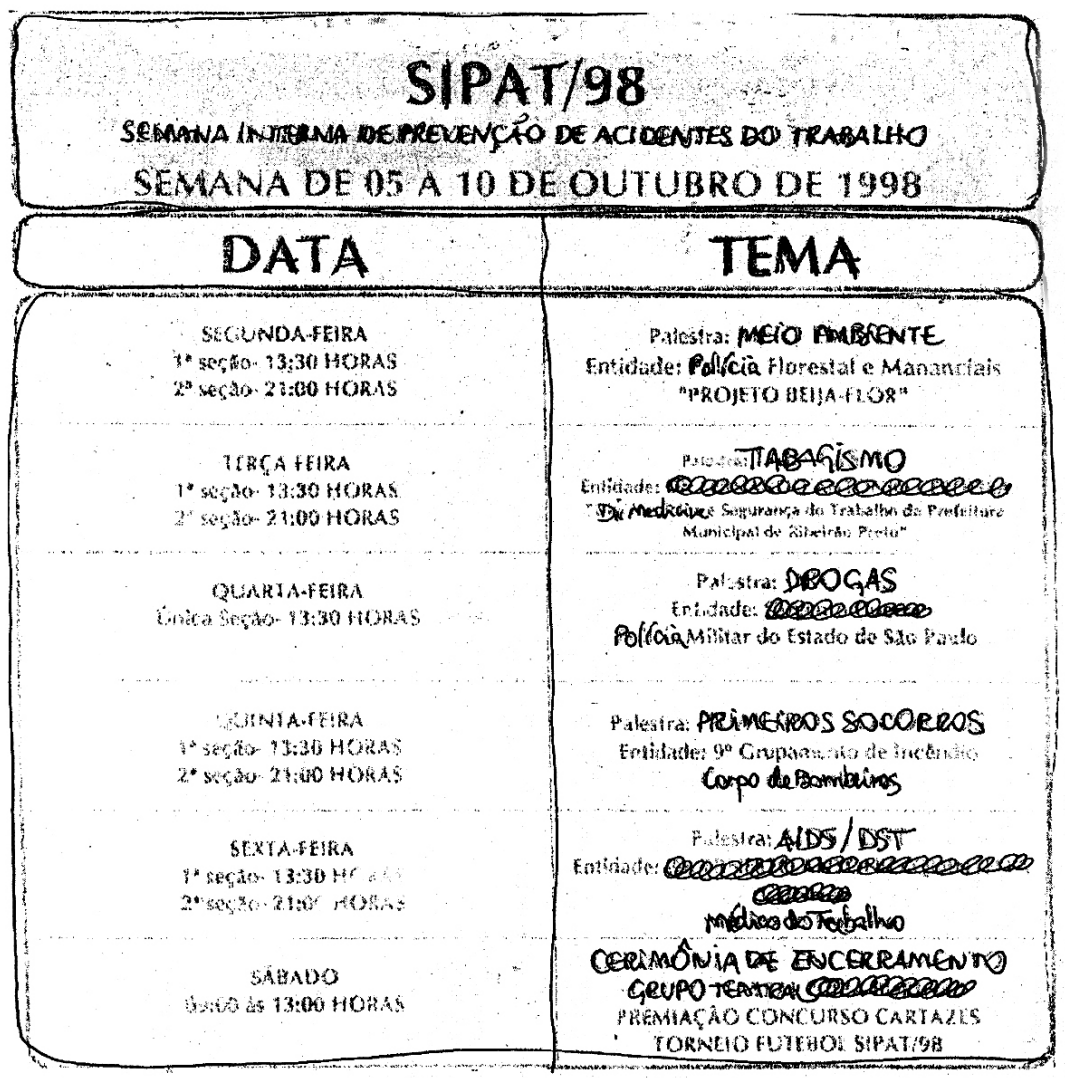


ANEXOG

Informativo Distribuido pelo seSMT
SEGURANGCA E MEDICINA DO TRABALHO)
Tema: Stress
InstruçOA A PREVENCAO ANNBA EOMELHOR REMEDIO

O STRESS éun inimigo silenviogs; gue prode cau sar sérios danos á saúde.

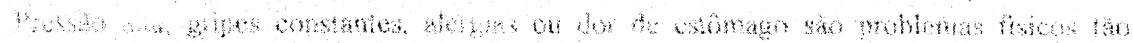

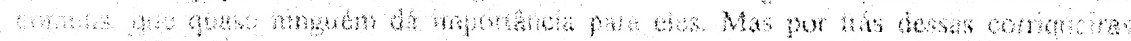

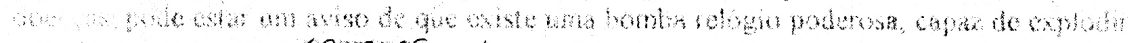
atghe momeno ASTRESS.

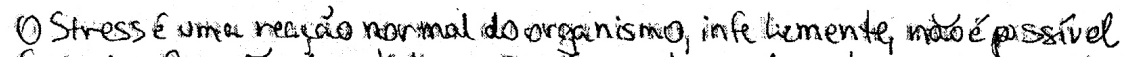

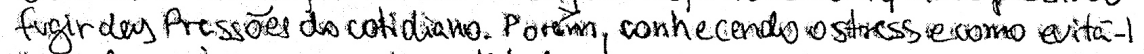
the, pote se viever com nous quadidade.

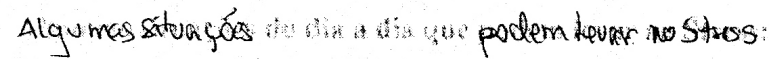

D.e.n.

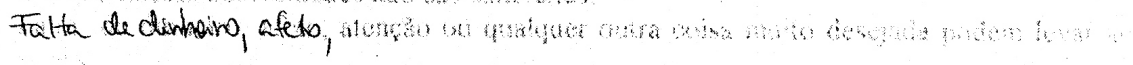

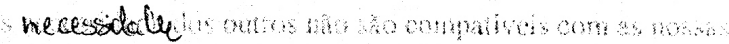

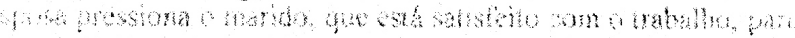

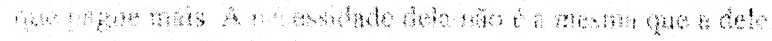

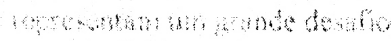

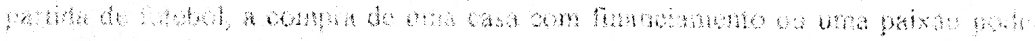

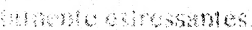

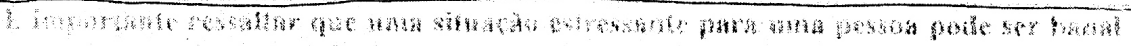

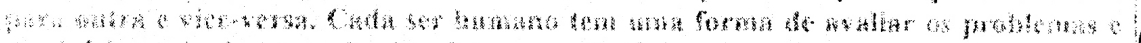

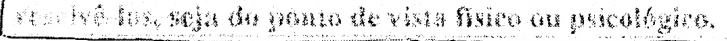

\section{PREVENCATO}

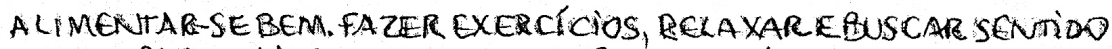
PAR A UIBA AJU DAMA SUPER AR OUEUTTAR O STRESS. 
ANEXO H

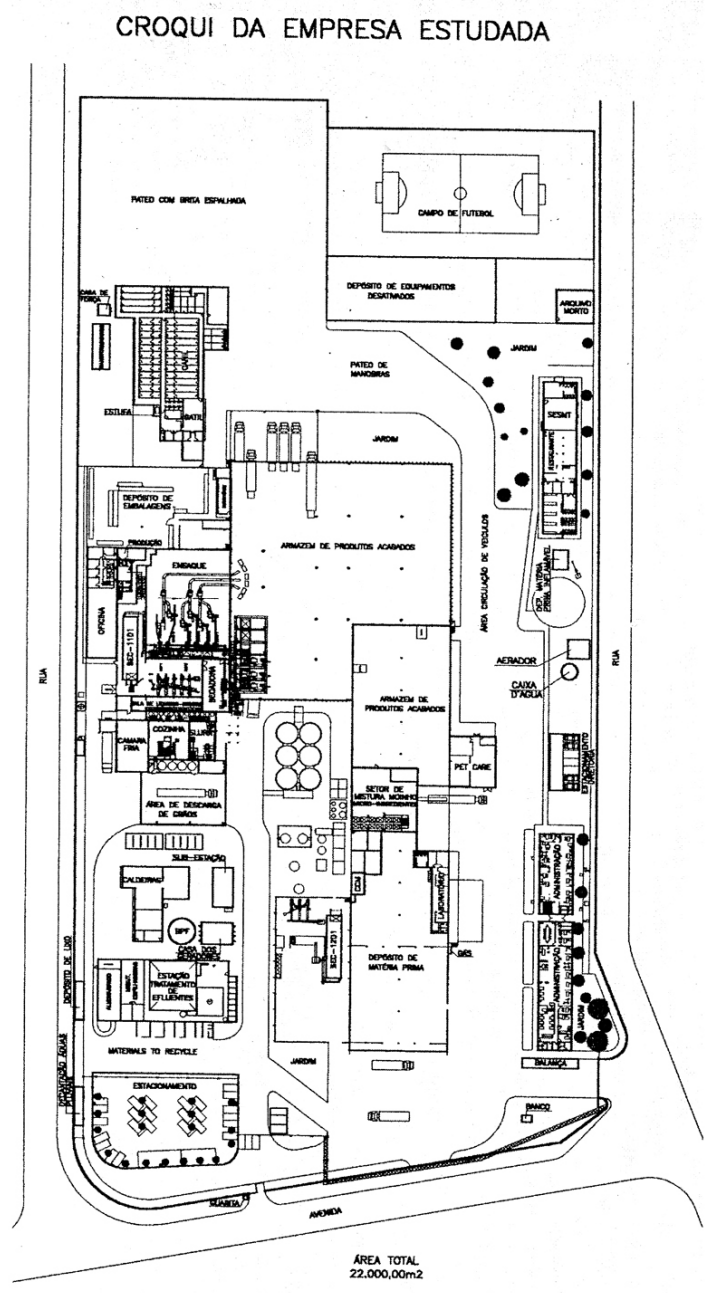




\section{ANEXO E}

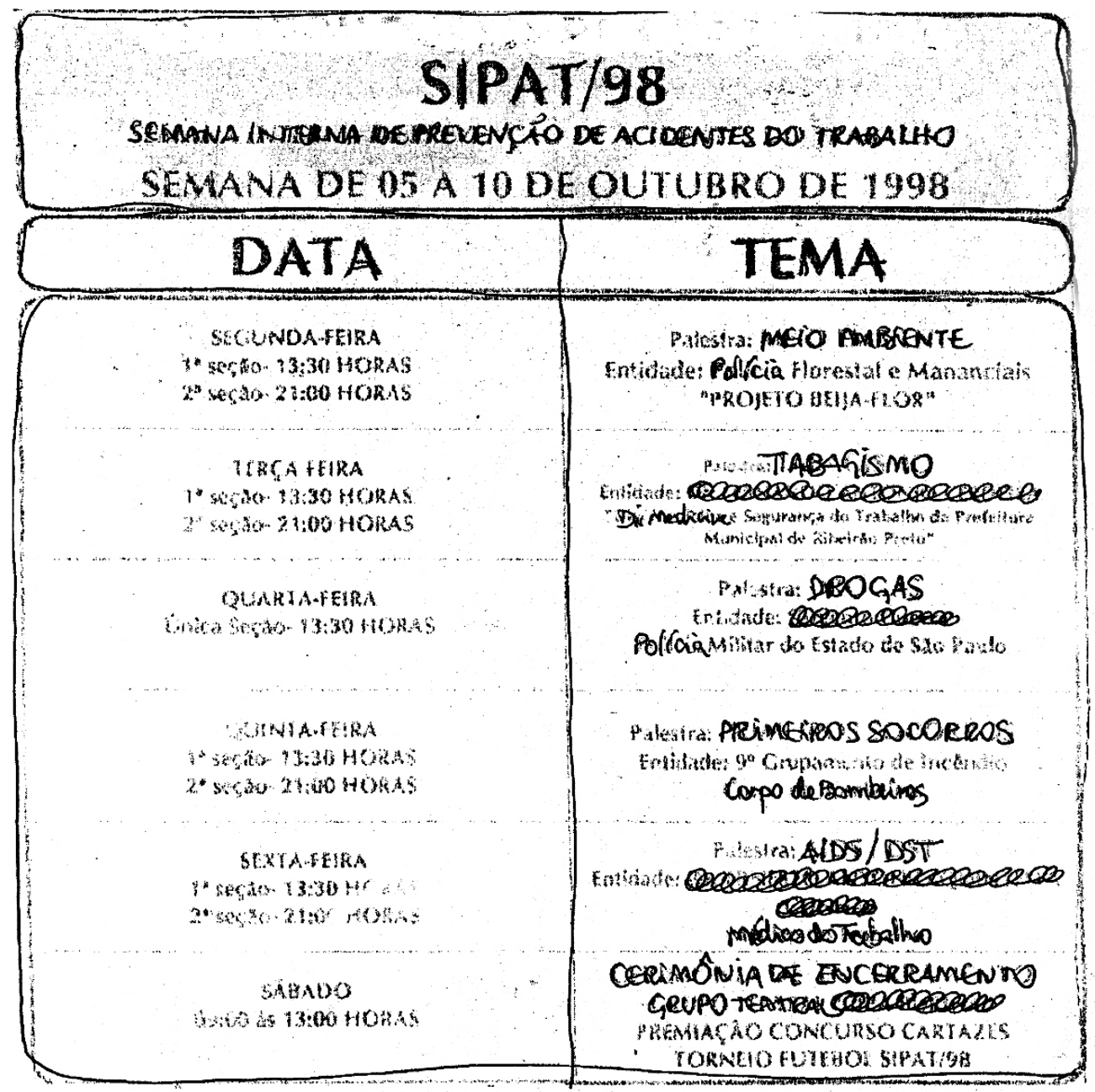

